\title{
Gene expression profiling of tumor angiogenesis
}

Citation for published version (APA):

van Beijnum, J. R. (2006). Gene expression profiling of tumor angiogenesis. [Doctoral Thesis, Maastricht University]. Universiteit Maastricht. https://doi.org/10.26481/dis.20060427jb

Document status and date:

Published: 01/01/2006

DOI:

10.26481/dis.20060427jb

Document Version:

Publisher's PDF, also known as Version of record

\section{Please check the document version of this publication:}

- A submitted manuscript is the version of the article upon submission and before peer-review. There can be important differences between the submitted version and the official published version of record.

People interested in the research are advised to contact the author for the final version of the publication, or visit the DOI to the publisher's website.

- The final author version and the galley proof are versions of the publication after peer review.

- The final published version features the final layout of the paper including the volume, issue and page numbers.

Link to publication

\footnotetext{
General rights rights.

- You may freely distribute the URL identifying the publication in the public portal. please follow below link for the End User Agreement:

www.umlib.nl/taverne-license

Take down policy

If you believe that this document breaches copyright please contact us at:

repository@maastrichtuniversity.nl

providing details and we will investigate your claim.
}

Copyright and moral rights for the publications made accessible in the public portal are retained by the authors and/or other copyright owners and it is a condition of accessing publications that users recognise and abide by the legal requirements associated with these

- Users may download and print one copy of any publication from the public portal for the purpose of private study or research.

- You may not further distribute the material or use it for any profit-making activity or commercial gain

If the publication is distributed under the terms of Article $25 \mathrm{fa}$ of the Dutch Copyright Act, indicated by the "Taverne" license above, 


\section{Gene expression profiling of tumor angiogenesis}


(C) J.R. van Beijnum, Maastricht 2006 ISBN-10: 90-9020568-3

ISBN-13: 978-90-9020568-7

Printed by Grafisch bedrijf Ponsen en Looijen B.V.

Special thanks to Toon Hezemans - Tejo Haas Productions 


\section{Gene expression profiling of tumor angiogenesis}

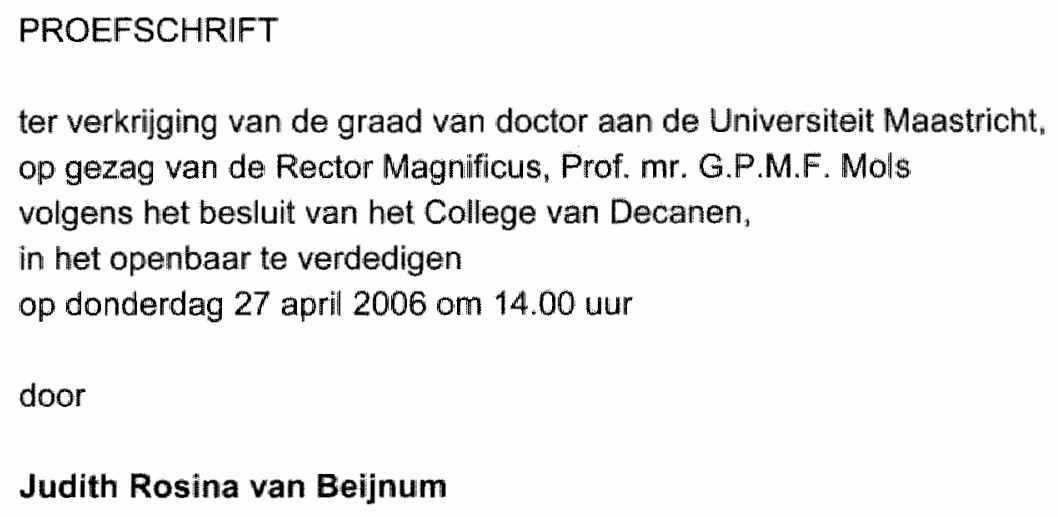

ter verkrijging van de graad van doctor aan de Universiteit Maastricht op gezag van de Rector Magnificus, Prof. mr. G.P.M.F. Mols volgens het besluit van het College van Decanen, in het openbaar te verdedigen op donderdag 27 april 2006 om 14.00 uur

door

Judith Rosina van Beijnum

geboren op 11 december 1977 te Nijmegen 
Promotor:

Prof. dr. A.W. Griffioen

Beoordelingscommissie:

Prof. dr. d. Waltenberger (Voorzitter)

Prof dr R. Bicknell (Birmingham University, United Kingdom)

Prof. dr. W.A. Buurman

Dr. M.F.B.G. Gebbink (Universiteit Utrecht)

Proff. dr. B.G. Wouters

Financial support by the Dr. Ir. Van de Laar Stichting for the publication of this thesis is gratefully acknowledged. 


\section{> Abbreviations}

$3 \mathrm{D}$

$A b$

AGE

BCE

BSA

DFGF

BPI

CAM

CDC.

CDNA

$C M$

DNA

EC

ECM

EGF

EMT

EST

$\mathrm{EtOH}$

FACS

GAG

HDMEC

HGF

$H I F-1 \alpha$

HMEC

HMGB1

HMVEC

HUVEC

ICAM1

IGFBPT

IL

MMP

NEC

NFKB

NGR

NRP

ODN

PAK

PBS

PF

PF4

PKC
Three-dimensional

Antibody

Advanced glycation end product(s)

Bovine capillary endothelial cell(s)

Bovine serum albumin

Basic fibroblast growth factor

Bactericidal/permeability-increasing protein

Chick chorioallantoic membrane

Cell division cycle

Complementary DNA

Conditioned medium

Deoxyribonucleic acid

Endothelial cell(s)

Extracellular matrix

Epidermal growth factor

Epithelial-mesenchymal transition

Expressed sequence tag

Ethanol

Fluorescence activated cell sorting

General angiogenesis gene

Human dermall microvascular endothelial cell(s)

Hepatocyte growth factor

Hypoxia inducible factor $1 \alpha$

Human microvascular endothelial cell(s)

High-mobility group box 1

Human microvascular endothelial cell(s)

Human umbilical vein endothelial cell(s)

Intercellular adhesion molecule 1

Insulin-like growth factor binding protein 7

Interleukin

Matrix metalloproteinase

Normal endothellial cell(s)

Nuclear factor $\mathrm{k} B$

Asparagine-glycine-arginine

Neuropillin

Oligodeoxymucleatide

p21 activated kinase

Phosphate buffered saline

Paraformaldehyde

Platelet-factor 4

Protein kinase C 


$\begin{array}{ll}\text { PLEC } & \text { Placenta endothelial cell(s) } \\ \text { PMA } & \text { Phorbol myristate acetate } \\ \text { RAGE } & \text { Receptor for advanced glycation end products } \\ \text { RGD } & \text { Arginine-glycine-aspartic acid } \\ \text { RNA } & \text { Ribonucleic acid } \\ \text { RNAi } & \text { RNA interference } \\ \text { ROK } & \text { Rho activated kinase } \\ \text { SAGE } & \text { Serial analysis of gene expression } \\ \text { ShRNA } & \text { Small hairpin RNA } \\ \text { SIRNA } & \text { Small interfering RNA } \\ \text { SPARC } & \text { Secreted protein, acidic, rich in cysteine } \\ \text { SSH } & \text { Suppression subtractive hybridization } \\ \text { TAG } & \text { Tumor angiogenesis gene } \\ \text { TEC } & \text { Tumor endothelial cell(s) } \\ \text { TEM } & \text { Tumor endothelial marker } \\ \text { TIE } & \text { Tyrosine kinase with immunoglobulin-like and EGF-like domains } \\ \text { TNF } \alpha & \text { Tumor necrosis factor } \alpha \\ \text { TSP1 } & \text { Thrombospondin 1 } \\ \text { VCAM1 } & \text { Vascular cell adhesion molecule 1 } \\ \text { VEGF } & \text { Vascular endothelial growth factor } \\ \text { VEGFR } & \text { VEGF receptor }\end{array}$




\section{> Contents}

Chapter 1 General introduction

Chapter 2 In silico analysis of angiogenesis associated gene expression identifies angiogenic stage related profiles

Chapter 3 Gene expression of tumor angiogenesis dissected; specific targeting of tumor endothelium

Chapter $4 \quad$ Interference with vimentin expression affects the angiogenic potential of tumor endothelial cells

Chapter 5

High-mobility group box 1 (HMGB1) positively contributes to tumor angiogenesis

Chapter $6 \quad$ Towards high-throughput functional target discovery in angiogenesis research

Chapter $7 \quad$ General discussion

Summary

Samenvatting 156

Dankwoord 160

Curriculum Vitae 


\section{Chapter 1}

\section{General introduction}

Based on:

Femke Hillen, Veerle Melotte, Judy R. van Beijnum, Arjan W. Griffioen. Endothelial cell biology. In: Staton CA, Lewis C, Bicknell $R$, editors. Angiogenesis assays: a critical appraisal of current techniques. London, United Kindom: John Wiley and Sons. In press. 


\section{> Angiogenesis and tumor angiogenesis}

Angiogenesis, the formation of new blood vessels from pre-existing ones, is pivotal to a variety of physiological as well as pathological processes. Most tissues are critically dependent on an adequate supply of oxygen and nutrients and removal of waste products via the vasculature. Normal tissue growth, for example during prenatal development, wound healing and during the female reproductive cycle is characterized by new vessel formation. Anglogenesis is also induced during pathological conditions including cancer progression, arthritis, atherosclerosis, endometriosis and diabetic retinopathy [1].

In normal tissues, a balance is maintained between the effects of anti-angiogenic factors and those of pro-angiogenic factors, and endothelial cells (EC) are generally quiescent displaying little or no proliferation. Disturbance of this balance in favor of proangiogenic factors is referred to as the 'angiogenic switch' [2]. Angiogenesis can be switched on in response to various stimuli, including hypoxia, metabolic stress and cellular signals. The limited diffusion of oxygen and nutrients is about 100-200 $\mu \mathrm{m}$ [3], therefore, initial tumors can not grow beyond a size of approximately $2 \mathrm{~mm}^{3}$ without the attraction of novel blood vessels.

Once angiogenesis is initiated, a sequence of events is set in motion. Under the influence of pro-angiogenic factors, EC lining existing blood vessels become activated. Before they can migrate in the direction of the stimulus, the underlying basement membrane is degraded by matrix metalloproteinases (MMPs), which are produced by EC, tumor cells, fibroblasts and inflammatory cells [1]. To extend towards the tissue in need of vascular supply, the EC proliferate and form a tube-like structure that is stabilized by mural cells such as pericytes during the maturation phase (Figure 1.1). In tumors however, continuous angiogenic stimulation results in the formation of a highly distorted vasculature that frequently lacks pericyte coverage, shows excessive branching and is uneven in diameter. Blood flow is chaotic and variable which may help sustain hypoxia and hence continued angiogenic stimulation in certain regions of the tumor [3]. Furthermore, tumor blood vessels are leaky due to widened interendothelial junctions, the presence of a discontinuous basement membrane and protrusions of $\mathrm{EC}$ into the vascular $\| u m e n \llbracket[3,4]$.

\section{> Regulation of angiogenesis}

\section{Pro-angiogenic factors}

A vast number of secreted pro-angiogenic factors and their receptors have been described over the last decades (for recent reviews see [5-8]) and novel insights in human biology continue to extend the number of positive contributors to angiogenesis. One of the best-known pro-angiogenic factors is vascular endothelial growth factor (VEGF), first discovered in 1983 as vascular permeability factor by Harold Dvorak [9]. 
VEGF is a survival factor for endothelial cells but also stimulates EC to secrete MMPS to allow invasion into the surrounding matrix [10]. VEGF can be released from tumor

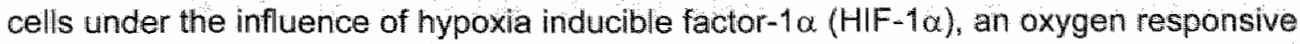
transcription factor. In addition, mutations in tumor-suppressor genes (e.g. p53) and oncogenes (e.g. Ras and ErbB-2) in tumor cells may also stimulate VEGF release via induction of HIF-1 $\alpha[11-13]$. The biological effects of the VEGF family are mediated via cell surface VEGF receptors FIt-1 (VEGFR-1), KDR (VEGFR-2) and FIt-4 (VEGFR-3), the latter being mainly present on lymphatic endothelial cells [10]. To date, VEGF-A is the best characterized molecule of the VEGF family. It interacts with both Flt-1 and KDR but these receptors have different effects. KDR is the major mediator of the mitogenic and angiogenic effects of VEGF-A. Flt- 1 is involved in the induction of MMPs but may also function as a decoy receptor $[14,15]$.

Basic fibroblast growth factor (bFGF) is another important pro-angiogenic factor that stimulates EC proliferation and survival. bFGF signaling occurs through four high affinity tyrosine kinase transmembrane receptors (FGFR1-4). It is produced by many cells, among which macrophages and tumor cells, and is subsequently secreted into the extracellular matrix (ECM). bFGF binds to heparan sulfate proteoglycans,

A

B

C

D

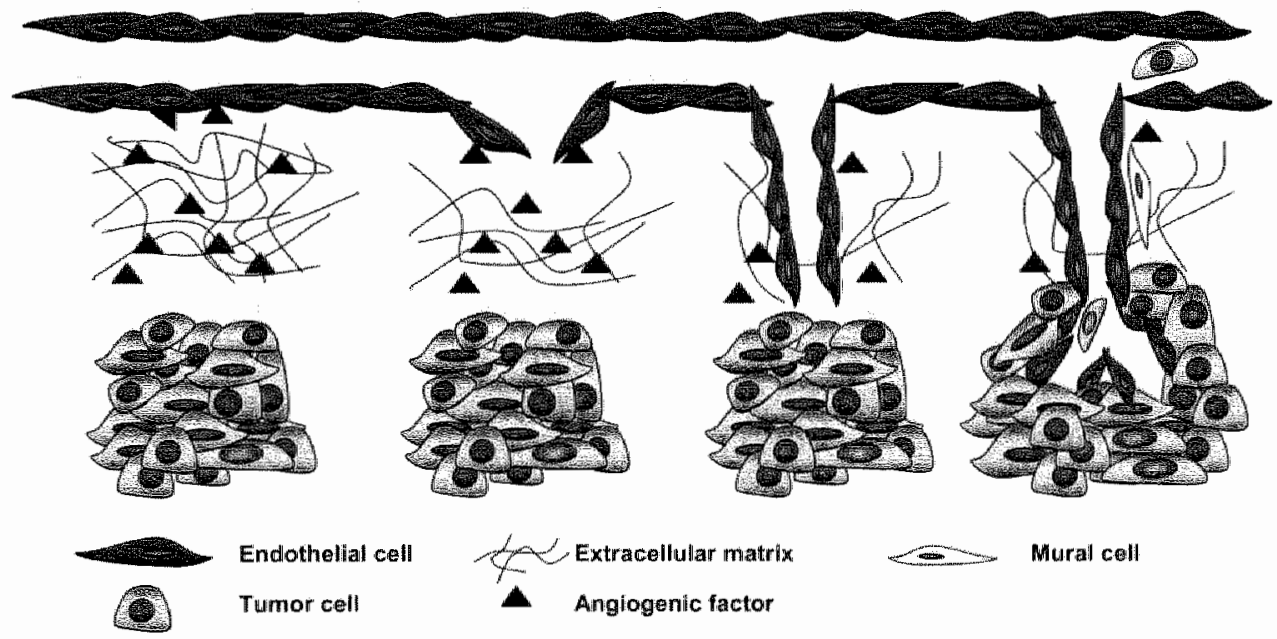

Figure 1.1: Schematic representation of tumor angiogenesis.

A) In response to hypoxia, tumor cells secrete angiogenic factors that activate endothelial cells in a nearby vessel. B) Angiogenesis is initiated when activated endothelial cells degrade the underlying matrix and start to migrate towards the angiogenic stimuli. C) Proliferation of endothelial cells allows the formation of a tube structure in the direction of the tumor. D) A newly formed vascular network enables the tumor to continue growth and may in addition be used as a metastatic route. 
located on the surface of many cells and in the ECM, and can be released by matrix degrading enzymes. Several intracellular signaling pathways are activated by bFGFFGFR interaction, including the Ras pathway and the PI3K pathway $[7,10]$.

Angiopoietins and their TIE (tyrosine kinase with immunoglobulin-like and EGF-like domains) receptors are also critical regulators of angiogenesis. Angiopoietin-1 (Ang-1) interacts with TIE2 and inhibits EC apoptosis and stimulates endothelial sprouting $[8,16]$. Ang- 1 is further required for remodeling and maturation of immature vasculature as it stimulates the recruitment of pericytes. Ang-2 is involved in postnatal angiogenic and vascular remodeling events and in detaching smooth muscle cells and loosening underlying matrix, thereby allowing EC to migrate. Ang-2, in concert with VEGF is also angiogenic, although in the absence of VEGF, Ang-2 may actually induce vessel regression $[17,18]$.

\section{Guidance molecules}

Recent studies have showed some analogies between molecular regulation of neural development and angiogenesis (reviewed by Klagsbrun [6] and Suchting [19]). Neuropilins (NRPs) are receptors for the repulsive axon guidance factors class 3 Semaphorins (Sema3). Sema3A is a ligand for NRP-1 whereas Sema3F is a ligand for NRP-2 [20,21]. In addition, NRPs function as receptors for specific VEGF splice variants [22]. Semaphorins and VEGF compete for binding the NRPs, hence they inhibit VEGF-mediated angiogenesis [23]. Semaphorins also have a direct inhibitory effect on EC migration, protrusion of lamellipodia and sprouting [23], possibly through influencing endothelial integrins [24]. Ephrin ligands and Eph receptors have also been recognized for their role in stimulating angiogenesis [25], after initially being implicated in repulsive neuronal guidance [26]. Both the Eph receptors and their ephrin ligands are membrane-bound and play important roles in arterio-venous differentiation and in positioning EC $[6 ; 25]$. Eph-ephrin signaling cross-signals with the VEGF-VEGFR axis, for example, blockade of the EphA receptor inhibits VEGF induced angiogenesis [2730]. More recently, secreted Slit proteins and their roundabout receptors (Robo) were demonstrated to play a role in angiogenesis next to their roles in axon pathfinding $[6,19,28,31]$. Whether in angiogenesis they are either attractant or repulsive is still under debate. Slit2 promoted endothelial tube formation and acted as a chemoattractant in vitro. Blocking its receptor Robo1 reduced tumor angiogenesis in a mouse tumor model [32]. Another report however showed that exposure of EC to Slit2 inhibited migration [33]. Soluble Robo4 was shown to inhibit EC migration and proliferation [33,34], but its binding to any of the Slit proteins is still under debate. Finally, netrins, bi-functional guidance cues in neuronal development, have been implicated in regulating angiogenesis. Netrins can interact with two types of receptors, deleted in colorectal cancer (DCC) and the uncoordinated-5 (Unc5) family [35]. Endothellial tip cells express Unc5b, and treatment with Netrin- 1 resulted in tip cell filopodia retraction [36], suggesting negative regulation of angiogenesis by this 
ligand/receptor pair. However, others have reported Netrin-1 to be a pro-angiogenic factor [37].

Many parallels between neuronal guidance and angiogenesis have been uncovered that help organize network formation by a combination of attractive and

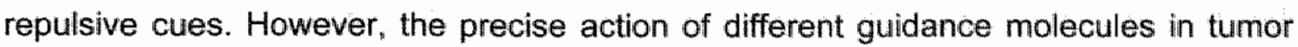
angiogenesis has not been elucidated yet and contradicting results have been obtained. Nevertheless, these findings expand our knowledge on the molecular regulation of angiogenesis $[6,19]$.

\section{Anti-angiogenic factors}

Several endogenous anti-angiogenic factors have been discovered that counterbalance the actions of pro-angiogenic factors. In 1980, interferon- $\alpha$ was shown to inhibit EC migration [38] and has been used since 1988 to treat primarily hemangiomas and angioblastomas [39]. Interferon- $\alpha$ inhibits the production of bFGF, the angiogenic factor these tumors are highly dependent on [40]. Thrombospondin-1 (TSP1) is an adhesive glycoprotein that mediates cell-to-cell and cell-to-matrix interactions $[41,42]$. Binding of TSP1 to CD36 activates apoptosis by inducing p38 and jun $\mathrm{N}$-terminal kinase, and subsequently the cell-surface expression of Fas ligand that triggers the caspade cascade $[43,44]$. Platelet factor-4 (PF4) has also been mentioned as endogenous angiogenesis inhibitor $[1,45]$. PF4 can directly interact with proangiogenic growth factors such as bFGF and VEGF [45]. In addition, PF4 derived molecules also have anti-angiogenic action $[46,47]$.

Bacterícidal/permeability-increasing protein (BPI), produced by neutrophils, has antibacterial effects, but also shows similarities to PF4. BPI inhibits EC growth, induces EC apoptosis and inhibits angiogenesis in vitro and in vivo [48]. Though the receptor for BPI is unknown, it is likely that its effects are mediated by binding heparan sulphates in the ECM [48].

Interestingly, many endogenous angiogenesis inhibitors are cleavage products from larger proteins. For example, endostatin is a fragment of collagen XVIII, angiostatin is a fragment of plasminogen and tumstatin is a fragment of collagen IV. The collagen fragments endostatin and tumstatin are formed by MMP cleavage of the respective collagens and may function as negative feedback molecules during vascular remodeling. Their precise mechanism of action has not yet been fully elucidated but several studies point to interactions with endothelial integrins that mediate their effects [49].

\section{> Angiogenesis inhibition}

The hypothesis that tumor growth is angiogenesis-dependent was postulated over three decades ago [50], and triggered a wide interest in inhibiting this process as a novel therapeutic strategy to treat cancer. Though angiogenesis does not initiate tumor 
growth, it promotes tumor progression to clinical significance and offers a major route for metastatic spreading of turnor cells to other locations in the body. Different antiangiogenic and vascular targeting agents have been developed over the last decades and this recently resulted in the FDA approval of Avastin ${ }^{\text {"M }}$, an anti-VEGF antibody for the treatment of metastatic colorectal cancer [51].

\section{Anti-angiogenesis as cancer treatment}

Therapeutic inhibition of tumor angiogenesis is considered to have a number of major advantages over the current conventional therapies (surgery, radiation and chemotherapy). One blood vessel provides metabolic support to a surrounding area of tumor celis, hence, eradication of only a limited number of endothelial celis will result in the death of a multitude of tumor cells. Another major advantage is that EC are generally accessible via the blood stream. This makes the delivery of anti-angiogenic agents relatively easier as compared to chemotherapeutic drugs targeting the tumor cells (that first need to diffuse into the tumor mass), especially when large molecules such as antibodies are used as therapeutics, as with Avastin ${ }^{\mathrm{TM}}$. One of the major disadvantages of chemotherapy is its deleterious effect on non-malignant cells causing severe side effects. Angiogenesis is limited in adult life, hence interference in this process is thought to result in much less severe side effects. Nevertheless, impaired physiological angiogenic responses have been observed in patients treated with Avastin $^{\mathrm{TM}}$ [52]. Finally, unlike tumor cells that frequently contain genomic mutations, EC in a tumor are the offspring of normal endothelial cells and are considered to be genetically stable, diminishing the chance of acquired drug resistance associated with clonal selection of mutations [53]. Though in essence this may be correct, in clinical practice resistance to anti-angiogenic therapy is noticeable $[54,55]$. EC heterogeneity, between individuals as well as within a tumor as a consequence of microenvironmental actions, may confer selective sensitivity to certain anti-angiogenic agents. Also, genetic drift may modulate the angiogenic profile of a tumor, i.e. the types and relative amounts of different pro-angiogenic factors it secretes, which may drastically limit the effect of an inhibitor directed at only one type of angiogenic factor [14,56]. Furthermore, tumor cells may become increasingly hypoxia resistant [57], hence less dependent on angiogenesis. Since tumors have also been shown to use alternative routes to vascularization, e.g. vessel cooption, vascular mimicry and recruitment of bone marrow derived cells [58], their sensitivity to angiogenesis inhibition is not always guaranteed. In addition, two recent studies have shown that tumor EC can harbor genetic abnormalities $[59,60]$.

\section{Angiogenesis inhibitors}

The realization that cancer could be treated and prevented by targeting its blood supply created an explosion of interest in finding inhibitors of angiogenesis. In addition to endogenous angiogenesis inhibitors (described above), numerous compounds have been developed and tested, some of which are highlighted below. 
VEGF is the most frequently targeted molecule for anti-angiogenesis. In addition to the anti-VEGF antibody Avastin ${ }^{\mathrm{T} M}$ that scavenges VEGF, a chimaeric soluble VEGF receptor (VEGF-Trap) is also able to reduce local VEGF concentrations [61]. Furthermore, many compounds have been developed that target the tyrosine kinase activity of VEGF receptors, for example PTK787 [62] and SU11248 [63], currently in clinical trials. Inhibitors of MMPs are also under investigation [64-66].

Anginex is a designed cytokine-like peptide that was selected from a library of synthetic peptides with homology to endogenous anti-angiogenic proteins [67]. It is a potent inhibitor of EC proliferation and migration in vitro [67], and inhibits tumor growth in mice by targeting tumor EC $[46,68]$. Anginex synergizes with conventional chemotherapeutics, other angiogenesis inhibitors and radiation therapy to inhibit tumor growth $[69,70]$. More recently, partial mimetics of anginex were shown to be even more potent inhibitors of tumor growth in mice models [71]. Furthermore, recombinant anginex has been successfully produced to exploit its tumor endothelium targeting capacities for gene therapy purposes and imaging [72].

Combretastatin A-4 phospate (combreAp) is a tubulin-polymerization interfering compound that is selectively toxic to EC. In addition, it inhibits endothelial migration and tube formation and induces apoptosis. Finally, it inhibits tumor growth in rats and mice [73]. CombreAp inhibits blood flow in tumors, leading to a rapid vascular shutdown and subsequently hypoxia and central necrosis [74].

Fumagillin, or TNP-470, inhibits EC proliferation without inducing apoptosis. It inhibits cell movement, but has only minor effects on tube formation [75]. It has been extensively tested in different tumor models and shown to be very effective. However, neurotoxicity limits its clinical utility [76]. Conjugated to a polymer to form caplostatin, fumagillin is no longer neurotoxic yet still effective in inhibiting tumor growth [77].

Though the primary aim of anti-angiogenic agents is the eradication of tumor blood vessels, many of them also transiently normalize tumor vasculature, thereby allowing a better penetration of cytotoxic drugs or sensitization of the tumor to radiotherapy [78]. Furthermore, not only classical anti-angiogenic agents can reduce the tumor vasculature. It has been proposed that chemotherapeutic compounds can be administered in an anti-angiogenic schedule, i.e. continued, low-dose administration, EC are killed by the compound and consequently tumor growth is inhibited. In contrast, administration of a maximum tolerated dose comprises the risk of tumor cells acquiring drug resistance and renewed outgrowth of the tumor $[14,79]$. In the future, the therapeutic potential of angiogenesis inhibitors might be further enhanced by optimization of dosing and combining different agents.

\section{Angiogenesis inhibition and vascular targeting}

Two general strategies can be employed to attack the tumor's blood supply. Either the formation of novel blood vessels can be inhibited, the narrow definition of angiogenesis inhibition, but it is also possible to destroy existing tumor vessels, frequently referred to as vascular targeting. However, depending on the mode of action 
of the agent, there is considerable overlap between these two applications. For example. VEGF inhibition both prevents angiogenesis but as it also acts as a survival

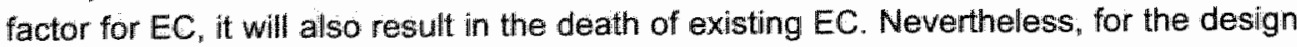
of effective anglogenesis inhibitors or vascular targeting agents for cancer treatment, thorough knowledge of EC biology is a prerequisite.

\section{$>$ Endothelial cell heterogeneity}

The endothelium exhibits a remarkable diversity of cellular properties that are adapted to the needs of the underlying tissue, which is rellated to the microenvironmental factors acting in each different organ and the specialized function for the endothelium therein [80-82]. Even within one organ, EC display heterogeneity.

EC heterogeneity may be explained by variations in the microenvironment ('nurture") as well as by genetic predisposition ('nature') [83]. Interactions between EC and their precise microenvironments are thought to play an important role in determining the phenotype of the EC. Depending on the tissue or organ, different soluble mediators may be present that act on the EC and EC may be in contact with different cell types or matrix components. In addition, hemodynamic factors may also govern changes in endothelium [84].

\section{Microenvironment}

EC heterogeneity may be exploited therapeutically. As described below and in other chapters of this thesis, EC display tissue specific features that are mediated by the microenvironment. Expression of specific markers on EC of for example tumors may be targeted in a therapeutic setting to accomplish eradication of these cells without major side effects arising from targeting EC in healthy tissues or organs. The pronounced influence of the microenvironment on EC phenotype has major implications for the study of specific EC subpopulations derived from particular organs or tissues. EC isolated from specific locations in the body that are subsequentlly cultured may lose some of their tissue-specific characteristics, or acquire new phenotypic properties in response to the new environment in vitro (reviewed by Aird [82]). Merely culturing EC might already induce changes. For example, blood-brain barrier EC that specifically express P-glycoprotein lose this expression in vitro. When cultured in the presence of brain matrix or astrocytes, the expression is restored, though matrix derived from other organs is not capable of stimulating this expression [85].

The identification of organ- and disease-specific vascullar markers has been compromised by difficulties in isolating pure populations of EC and subsequent culture. The isolation of capillary EC from tissues faces challenges related to the relatively limited percentage of EC present in tissues and the impossibility for canulation of the small vessels, unlike larger vessels. Diverse methods have been used to isolate EC 
from tissues, mainly based on the expression of endothelial specific markers, by using fluorescence activated cell sorting (FACS) [86] or by cell sorting using magnetic beads [87] following enzymatic tissue digestion (Figure 1.2).

\section{Vascular address system}

Peptide libraries displayed on the surface of phage have also been used to identify vascular markers [88]. This method relies on binding of the displayed peptide with vascular cell surface molecules in organs and tissues. Bound phage can be isolated from the tissues and the coding sequence of the peptide analyzed. This approach provides information on the ligand that interacts with the surface markers, though it does not elucidate the identity of the marker itself.

In vivo phage display offers an unbiased approach to identify surface markers on EC. Random peptides displayed on phage were injected in mice and recovered from different organs and malignancies where they interacted with endothelial surface molecules. Peptides specific for brain vasculature have been identified as well as peptides that home to lung, pancreas, skin, intestine, uterus, adrenal gland, retina and prostate [89], and tumor vasculature [90,91]. This approach has provided clues of a vascular address system that can be used for organ-specific targeting of normal blood vessels or disease related targeting of blood vessels, such as in tumors $[90,91]$. The famous RGD sequence (arginine-glycine-aspartic acid) targets $\alpha \mathrm{V}$ integrins in tumor vessels [92] and the NGR sequence (asparagine-glycine-arginine) was shown to target aminopeptidase $\mathrm{N}$ or CD13 [93]. Differences exist between EC present in tumors compared to $E C$ in healthy tissue counterparts. Additional heterogeneity may exist

A

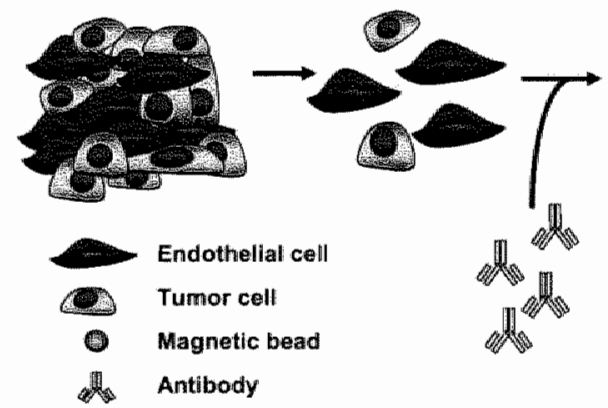

C

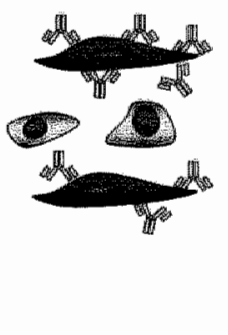

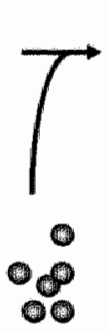

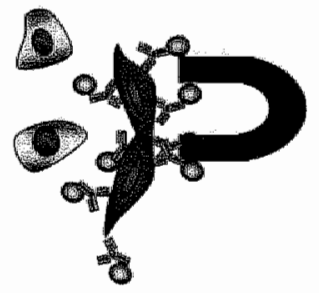

Figure 1.2: Isolation of endothelial cells from tissues.

A) Solid tissues (e.g. tumors) consist of diverse cells, including tumor cells, endothelial cells, stromal cells and inflammatory cells. B) The tissue mass is enzymatically digested to create a single-cell suspension. C) Antibodies specific for endothelial cells are allowed to bind. D) Magnetic particles with specific reactivity for the antibodies are added to the cell suspension and coat the endothelial cells. A magnet is used to pull the magnetic bead covered cells out from the total cell suspension. 
between different tumors and even within tumors [90]. Furthermore, stage-specific homing of phage-displayed peptides to tumor vasculature has been reported [94]. However, the identification of the molecule targeted by the peptide displayed on phage remains a challenging task.

\section{>> Gene expression in endothelial cells}

Endothelial cells in a particular microenvironment interact with various types of cells, such as fibroblasts, pericytes, immune cells, tumor cells or organ cells. In addition. EC can interact with various ECM components and are exposed to different growth factors and cytokines released by its neighbors [95]. As a result, EC lining different vesseis in different tissues exhibit morphological and functional specializations that are reflected in their gene expression profiles $[96,97]$.

\section{Arteries and veins}

Differences in gene expression have been observed between arterial and venous endathelium. These differences are established even before circulation begins [98]. Venous-specific genes, identified by large scale gene expression analysis of EC of diverse origin include EphB4 and NRP-2, and a number of genes critically involved in left-right asymmetry such as smoothened, lefty- 1 , lefty-2 and growth differentiation factor [96]. Interestingly, defects in left-right symmetry are frequently accompanied by vascular malformations [99]. Among the arterial endothelial specific genes are the cell surface proteins Notch4, EVA1, CD44 and Ephrin-B1, metabolic enzymes such as alcohol dehydrogenase $\mathrm{A} 1$ and endothelial lipase, keratin 7 and the basic helix-loophelix transcription factor Hey2 that is induced by Notch signaling [96].

\section{Large vessels and capillaries}

Clear differential expression is also evident between large vessel derived endothelium and microvascular endothelium [96]. Genes involved in biosynthesis and remodeling of ECM, such as fibronectin, osteonectin and collagens Va1 and Va2 are overexpressed in large vessel endothelium. Basement membrane proteins such as collagens IV 1 1 and IV $\alpha 2$, and their interaction partners such as integrins $a 4, a 1, a 9$ and 34 are overexpressed in microvascular EC. In addition, large vessel EC express genes associated with neuronal guidance such as those discussed above. In contrast microvascular EC express receptors for paracrine signals of neuroglial cells such as interleukin (IL)-1 receptor, IL-6 receptor, platelet-derived growth factor receptor (PDGFR) and endothelin receptor-1. Furthermore, microvascular EC express secreted factors that promote survival and differentiation of neuroglial cells [96]. In addition, EC display organ-specific gene expression. For example, osteoglycin, secreted frizzled related protein (sFRP) and phospholipase A2, group X\|IA (PLA2G12) were specific for 
lung endothelium, whereas galanin and the calcitonin receptor emerged as uterus specific. Skin endothelium expressed many genes involved in cholesterol biosynthesis, such as stearoyl-CoA desaturase (SCD), fatty acid desaturase (FADS2), and 3hydroxy-3-metheylglutaryl-CoA synthase 1 (HMGCS1), pointing towards active roles played by the endothelium in the organ physiology [96].

\section{$\gg$ Gene expression profiling for target identification}

Large-scale gene expression profiling has become feasible with the development of techniques such as serial analysis of gene expression (SAGE) [100], suppression subtractive hybridization (SSH) [101] and CDNA microarrays [102], and in the past decade vast amounts of data on gene expression in healthy and diseased tissues has been generated. In the early years, microarray technology was limited to the analysis of known genes that could be spotted on the arrays but since the recent completion of the human genome project virtually every gene that is expressed in the human body can be samplled. Refined techniques such as oligonucleotide arrays allow very high throughput gene expression profiling to be performed with very high sequence selectivity. In contrast to cDNA and oligonucleotide arrays, SSH and SAGE do not depend on known sequences. SSH involves the creation of CDNA libraries with genes overexpressed in one cell population compared to another [101]. Subsequent screening of these cDNA repertoires enables the identification of differentially expressed sequences. SAGE relies on the creation of sequence tags representative of a unique mRNA that are concatamerized and subsequently sequenced. The number of unique tags derived from cells in one condition is counted and compared to that of cells in another condition [100].

Analysis of gene expression can be used to determine molecular changes associated with particular phenotypes or diseases. The data can provide insight in the molecular mechanisms and pathways that govern disease. Importantly, differentially expressed genes may be used as targets for therapeutic intervention. For example. certain breast cancers overexpress ErbB-2, which is targeted by Herceptin ${ }^{\mathrm{TM}}$ [103]. The phenotypic differences of tumor EC as compared to EC in normal tissues argue for differences in gene expression that may be exploited therapeutically to attack the tumor's vasculature. Crucial to this is that the targeted gene is to a certain extent specific for the diseased tissue to prevent side effects associated with interference in non-diseased tissue.

\section{Therapeutic targets}

Some aspects need to be considered to determine whether a differentially expressed gene may be a putative therapeutic target. Surface expressed or secreted proteins are most easily accessible and can be used for targeted therapy using antibodies, small molecules with or without conjugation to cytotoxic molecules. Such 
targets can also be exploited for imaging purposes (e.g. for disease monitoring and diagnosis) by conjugation to detector molecules (Figure 1:3).

Differential expression of a gene can have either a causative or an associative relation to the disease or condition. Interfering with the function of a gene that has a causative contribution to the disease phenotype, for example involved in migration of cells, is most effective, as the whole process will be inhibited. Blocking differentially expressed genes that have a function in a process that does not directly contribute to the disease phenotype is not likely to give significant therapeutic effect.

Different agents can be designed to therapeutically target differentially expressed proteins. Antibodies can be used that black surface expressed proteins and hence inhibit cell function or induce antibody-mediated cytotoxicity. They can also be conjugated to bioactive molecules such as toxins or cytokines to accomplish bialogical effect. Other binding molecules (e.g. peptide ligands, aptamers) are also suitable. However, these approaches generally rely on targeting a surface expressed or secreted protein [104]. Gene vectors may be used to silence expression of intracellular targets and interrupt crucial cell processes, for example progression through the cell cycle, but also need to be delivered at the proper location. This can be achieved by changing the tropism of a viral vector to redirect it to the target cell [105], or by placing the transgene under control of a target cell specific promoter (transcriptional targeting) [106] (Figure 1.3),

Though the identification of differentially expressed genes involved in disease processes has been boosted by now readily available technologies, the validation of a gene as putative therapeutic target is still a time-consuming and labor-intensive process. Target identification can be performed in a high-throughput fashion, but target validation is mainly being performed on a gene-to-gene basis. In vitro methods can be increased in throughput [107], but in vivo validation remains laborious.

\section{>> Identification of tumor endothelial targets}

The identification of putative targets for therapeutic intervention in tumor angiogenesis or for vascular targeting holds promise for the future design of agents that combine the specificity of targeted therapy with the effectivity of attacking the tumor vasculature. The first proof that targeted anti-vascular therapy can eradicate solid tumors was provided by Burrows and Thorpe in 1993 [108]. They used a neuroblastoma cell line expressing interferon- $y$ that induced major histocompatibility class (MHC) class II expression on the tumor vasculature in a xenograft model. MHC class II on the tumor vasculature was targeted with an antibody coupled to ricin. The ricin caused cell death of the tumor endothelium and subsequent eradication of the tumor [108]. Unfortunately, the development of therapy targeted at the tumor vasculature in humans has been hampered by a limited availability of suitable targets so far identified. Different studies have attempted to identify tumor endothelial targets 


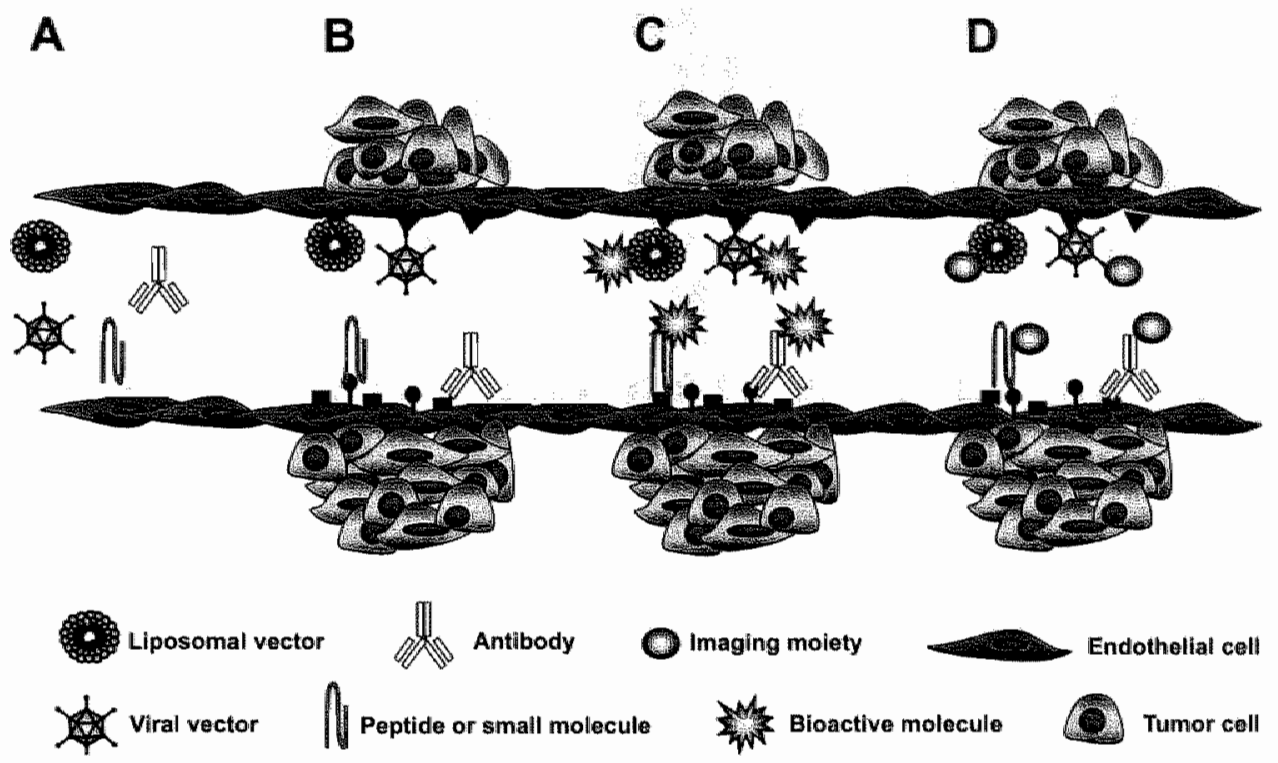

Figure 1.3: Targeting of tumor endothelium

A) Different binding molecules can be designed that can be administered intravenously. B) The binding of these targeting agents to the tumor vasculature depends on the presence of the appropriate target molecules on the tumor endothellum. The agents can act directly, or can be conjugated to bioactive molecules for local destruction of the fumor endothelium (C), or conjugaled to compounds that enable imaging of the tumor vasculature (D).

for anticancer therapy by using in vitro models that mimic the conditions in tumor and normal tissues respectively. However, as the microenvironment has a major influence on gene expression in EC [80-82], targets identified by in vitro models may not be readily applicable in vivo. To date, some tumor endothelial markers have been identified, but (pre-)clinical data is still limited.

\section{Tumor endothelial markers}

Using bioinformatics approaches, roundabout-4 (Robo4) and endothelial-specific protein disulfide isomerase (EndoPDI) were identified as endotheliall-specific genes $[109,110]$. Subsequent in situ hybridization showed predominant expression of Robo4 on the tumor vasculature [31]. Fibronectin containing the ED-B domain is undetectable in healthy tissues, but is abundantly present in the tumors and localizes to the vasculature [111]. The human antibody L19 was shown to localize to the tumor vasculature in animal models and in humans [112,113]. SAGE analysis of tumor EC identified a number of tumor endothelial markers (TEMs) [87]. One of these was later proven to be identical to endosialin, which is predominantly expressed by pericytes associated with tumor vessels [114]. Another TEM was shown to be the anthrax-toxin 
receptor. Binding of the toxin to the receptor elicits cell death, which may explain the antitumor activity of the toxin [115].

A few in wivo approaches have so far been exploited to identify tumor endothelial targets. Terminal perfusion of tumor-bearing rats with silica particles was performed to coat the luminal membrane of the endothellium for subsequent isolation using subcellular fractionation. Differentially expressed proteins were then identified by a combination of two-dimensionall gel electrophoresis and mass-spectrometry. Several proteins were shown to be upregulated on the tumor endothelium, including annexin A1, aminopeptidase N and NRP-1. Antibody-mediated targeting of annexin A1 was used for scintigraphic detection of tumors in rats, but also effectively eradicated the tumors [116]. A similar perfusion approach was performed using a biotin ester to label accessible endothelial molecules [117]. Biotinylated proteins were isolated using streptavidin and directly processed for identification by mass-spectrometry. Several tissue- and tumor-specific endothelial proteins were identified, including an acetyl-CoA carboxylase 265 fragment that was present on the endothelium of both F9 teratocarcinoma and RENCA renal carcinoma in mice [117]. Though these data are certainly promising, the quest for more and better targets for angiogenesis inhibition and vascular targeting needs to continue to have broader applicability and clinical effectivity.

\section{$>$ Outline of this thesis}

The aim of the work described in this thesis is the identification and validation of novel candidate target genes for therapeutic inhibition in tumor angiogenesis. For the design of novel and better anti-angiogenic and vascular targeting agents, it is crucial to have thorough knowledge of the differences in gene and protein expression in tumor EC versus normal EC. Various large-scale gene expression profiling surveys have been conducted in EC. Diverse in vitro models have been used to study the effects of angiogenic growth factors such as bFGF and VEGF on gene expression in EC [118122]. Furthermore, gene expression changes in tube-forming $E C$ in vitro have been studied [123-127]. In chapter 2, different studies describing gene expression changes in both growth factor stimulated EC in vitro and in tube-forming EC in vitro are compared. Furthermore, data obtained from SAGE analysis of isolated EC from different tumors are compared $[87,128,129]$.

Since angiogenesis is not limited to pathological conditions such as cancer, merely comparing gene expression profiles in tumor EC with that of normal EC will also result in the identification of molecules that are involved in physiological angiogenesis. Therapeutic targeting of such molecules could lead to unwanted side effects associated with impaired physiological angiogenesis. Based on the hypothesis that differences exist between angiogenic EC in tumors as compared to tissues with ongoing physiological angiogenesis, we performed a gene expression analysis of not 
only tumor and normal, resting EC, but also of placenta EC representative of physiological angiogenesis (chapter 3). Differential expression of a putative target between tumor angiogenesis and physiological angiogenesis creates a therapeutic window in which tumor angiogenesis might be affected without inducing side effects associated with physiological angiogenesis. Candidate genes were identified that are overexpressed in tumor EC compared to both normal, resting EC and physiologically activated placenta EC. The contribution of several cell-surface or secreted candidate genes to the process of angiogenesis was analyzed by different in vitro and in vivo assays. Vimentin, a well-known mesenchymal marker and type III intermediate filament protein was targeted using an antibody and inhibited tumor growth and angiogenesis. Further analysis showed that inhibition of vimentin expression in EC impairs migration and sprouting (chapter 4). Inhibition of high-mobility group box 1 (HMGB1), previously described as an inflammatory mediator, also resulted in impaired migration and sprouting of EC. This was accompanied by a decrease in MMP expression (chapter 5).

As the validation of putative therapeutic targets is a labor-intensive and timeconsuming effort, high-throughput methods are being developed that facilitate the process. First, validation assays can be miniaturized, allowing the parallel analysis of multiple putative targets. Second, functional screenings can be applied that directly isolate or identify a gene or protein that functionally contributes to a particular phenotype (chapter 6). These developments will allow for more straightforward target identification and validation of disease targets, thereby reducing time from the laboratory to the clinic. 


\section{$\gg$ References}

[1] Griffioen AW. Molema G. Angiogenesis: poltentials for pharmacologic intervention in the treatment of cancer cardiovascular diseases, and chronic inflammation. Pharmacol Rev 2000; 52 (2):237-68.

(2) Hanahan $\mathrm{D}$, Folkrian d. Patterns and emerging mechanisms of the angiogenic switch during tumorigenesis. Cell 1996:86 (3):353-64.

[3] Carmeliet $P$; Jain RK Angiogenesis in cancer and other diseases. Nature 2000;407 (6801):249-57.

[4] Hashizume $H$, Baluk $P$, Morikawa S, McLean JW, Thurston G, Roberge S, Jain RK, McDonald DM. Openings between defective endothelial celis explain tumor vessel leakiness. Am J Pathol 2000:156 (4):1363-80.

[5] Ferrara N. Vascular endothelial growth factor: basic science and clinical progress. Endocr Rev 2004:25 (4):581-611.

[6] Klagsbrun $M$. Eichmann A. A role for axon guidance receptors and ligands in blood vessel developmient and tumor angiogenesis. Cytokine Growth Factor Rev 2005;16 (4-5):535-48.

[7] Presta M, Dell'Era P, Mitola S, Moroni E, Ronca R, Rusnati M. Fibroblast growth factor/fibroblast growth factor receptor system in angiogenesis. Cylokine Growth Factor Rev 2005;16 (2):159-78.

[8] Tait $\mathrm{CR}$, Jones PF. Angiopoletins in tumours: the angiogenic switch. J Pathol 2004;204 (1):1-10.

[9] Senger DR, Galli SJ, Dvorak AM ${ }_{n}$ Pernuzzi CA, Harvey VS, Dvorak HF. Tumor cells secrete a vascular permeablity factor that promotes accumulation of ascites fluid. Science 1983;219 (4587):983-5.

[110] Cross MJ, Claesson-Welsh L. FGF and VEGF function in angiogenesis: signalling pathways, blological responses and therapeutic inhibition. Trendis Pharmacol Sci 2001;22 (4):201-7.

[11] Rak J, Filmus J, Finkenzeller $G$, Grugel $S$, Marme $D$, Kerbel RS. Oncogenes as inducers of tumor angiogenesis. Cancer Metastasis Rev 1995;14 (4):263-77.

[12] Laughner E, Taghavi P, Chiles K, Mahon PC, Semenza GL. HER2 (neu) signaling increases the rate of hypoxia-inducible factor 1alpha (HIF-1alpha) synthesis: novel mechanism for HIF-1mediated vascular endothelial growth factor expression. Mol Cell Biol 2001;21 (12):3995-4004.

Jones A, Fujiyama C, Blanche C, Moore JW, Fuggle S, Cranston D, Bickmell R, Harris AL. Relation of vascular endothelial growth factor production to expression and regulation of hypoxia-inducible factor-1 alpha and hypoxia-inducible factor-2 alpha in human bladder tumors and cell lines. Clin Cancer Res 2001;7 (5):1263-72.

[14] Ferrara N, Kerbel RS. Angiogenesis as a therapeutic target. Nature 2005:438 (7070):967-74.

[15] Waltenberger J, Claesson-Welsh L. Siegbahn A, Shibuya $M_{r}$ Heldin $C H$. Different signal transduction properties of KDR and Flt'1, two receptors for vascular endothelial growth factor. J Biol Chem $1994 ; 269(43): 26988-95$.

[16] Davis S, Yancopoulos GD. The angiopoietins: Yin and Yang in angiogenesis. Curr Top Microbiol Imrnunal 1999;237:173-85.

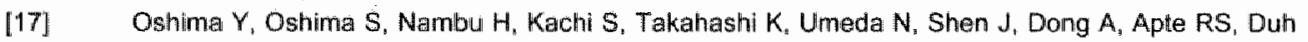
$E$, et al. Different effects of anglopoietin-2 in different vascular beds: new vessels are most sensitive. Faseb J 2005; $19(8): 963-5$.

[18] Maisonpierre PC, Suri C, Jones PF, Bartunkoval S, Wiegand S., Radziejewski C, Compton D. McClain J, Aldrich $\mathrm{TH}_{\mathrm{B}}$ Papadopoulos $\mathrm{N}_{\mathrm{a}}$ et al. Angiopoietin-2, a natural antagonist for Tie2 that disrupts in vivo anglogenesis. Science 1997;277 (5322):55-60.

[19] Suchting $S_{n}$ Bicknell $R_{n}$ Eichmann A. Neuronal clues to vascular guidance. Exp Cell Res 2005.

[20] He Z, Tessier-Lavigne M. Neuropilin is a receptor for the axonal chemorepellent Semaphorin III. Cell 1997;90 (4):739.51.

[21] Kolodkin AL, Levengood DV, Rowe EG, Tai YT, Giger RJ, Ginty DD. Neuropillin is a semaphorin III receptor. Cell 1997;90 (4):753-62.

[22] Soker S, Takashima S, Miao HQ, Neufeld G, Klagsbrun M. Neuropillin-1 is expressed by endothelial and tumor cells as an isoform-specific receptor for vascular endothelial growth factor. Cell 1998:92 (6):735 45 .

[23] Miao HQ, Soker S, Feiner L, Alonso JL. Raper JA, Klagsbrun M. Neuropilin-1 mediates collapsin1/semaphorin III inhibition of endothelial cell motility: functional competition of collapsin-1 and vascular endothelial growth factor 165 . J Cell Biol 1999:146 (1):233-42. 
[24] Serini $G$, Valdembri $D$, Zanivan $S$, Morterra $G$, Burkhardt $C$, Caccavari $F$, Zammatara $L$, Primo $L$ Tamagnone $L$, Logan $M$, et al. Class 3 semaphorins control vascular morphogenesis by inhibiting integrin function. Nature 2003;424 (6947):391-7.

[25] Heroult $M$, Schaffner $F$, Augustin HG. Eph receptor and ephrin ligand-mediated interactions during angiogenesis and tumor progression. Exp Cell Res 2005.

[26] Orioli $\mathrm{D}$, Klein $\mathrm{R}$. The Eph receptor family: axonal guidance by contact repulsion. Trends Genet 1997; $43(9): 354-9$.

[27] Chen J, Hicks D, Brantley-Sieders D, Cheng N, McCollum GW, Qi-Werdich X, Penn J. Inhibition of retinall neowascularization by soluble EphA2 receptor. Exp Eye Res 2005.

[28] Bicknell $R$, Harris $A L$. Novel angiogenic signaling pathways and vascular targets. Annu Rev Pharmacol Toxicol 2004;44:249-38.

[29] Kim II, Ryu YS, Kwak HJ, Ahn SY, Oh JL, Yancopoulos GD, Gale NW, Koh GY. EphB ligand, ephrinB2, suppresses the VEGF- and angiopoietin 1-induced Ras/mitogen-activated protein kinase pathway in venous endothelial cells. Faseb $J$ 2002;16, (9):1126-8.

[30] Vihanto MM, Plock J Erni $D_{n}$ Frey BM, Frey Fل، Huynh-Do U. Hypoxia up-regullates expression of Eph receptors and ephrins in mouse skin. Faseb J 2005; 19 (12):1689-91.

[31] Huminiecki $L$, Gorn $M_{8}$ Suchting $S$, Poulsom R, Bicknell R. Magic roundabout is a new member of the roundabout receptor family that is endothelial specific and expressed at sites of active angiogenesis. Genomics 2002;79 (4):547-52.

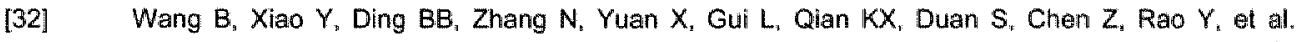
Induction of tumor anglogenesis by Slit-Robo signaling and inhibition of cancer growth by blocking Robo activity. Cancer Cell 2003;4 (1):19-29.

[33] Park KW, Morrison CM, Sorensen LK, Jones CA, Rao Y, Chien CB, Wu JY, Urness LD, Li DY. Robo4 is a vascular-specific receptor that inhibits endothelial migration. Dev Biol 2003;261 (1):25167.

[34] Suchting $S$, Heal $P$, Tahtis $K$, Stewart LM, Bicknell R. Soluble Robo4 receptor inhibits in vivo angiogenesis and endothelial cell migration. Faseb $\mathrm{J} 2005 ; 19(1): 121-3$.

[35] Hong $K$, Hinck $L$, Nishiyama $M$, Poo MM, Tessiler-Lavigne $M$, Stein E. A ligand-gated assoclation between cytoplasmic domains of UNC5 and DCC family receptors converts netrin-induced growth cone attraction to repulsion. Cell 1999;97 (7):927-41.

[36] Lu X, Le Noble F, Yuan L, Jiang Q, De Lafarge B, Sugiyama $D$, Breant C, Claes F, De Smet F, Thomas $\mathrm{JL}$, et al. The netrin receptor UNC5B mediates guidance ewents controlling morphogenesis of the vascular system. Nature 2004:432 (7014):179-86.

[37] Park KW, Crouse D, Lee M, Karnik SK, Sorensen LK, Murphy KJ, Kulo CJ, LI DY. The axonal attractant Netrin- 1 is an angiogenic factor. Proc Natl Acad Sci U S A 2004;101 (46):16210-5.

[38] Brouty-Baye D. Zetter BR. Inhibition of cell motility by interferon. Siclence 1980;208 (4443):516-8.

[39] Marler JJ, Rubin JB, Trede NS, Connors S, Grier H. Uplon J. Mulliken JB, Folkman J. Successful antiangiogenic therapy of giant cell angioblastoma with interferon alfa $2 b$; report of 2 cases. Pediatrics 2002;109 (2):E37.

[40] Singh RK, Gutman M. Bucana CD, Sanchez R, Llansa N. Fidler IJ. Interferons alpha and beta down-regulate the expression of basic fibroblast growth fiactor in human carcinomas. Proc Natl Acad Sci U S A 1995;92 (10):4562-6.

[41] Taraboletti G, Roberts D, Liotta LA, Giavazzi R. Platelet thrombospondin modulates endothellial cell adhesion, motility, and growth: a potential angiogenesis regulatory factor. I Cell Biol 1990;111 (2): $765-72$.

[42] Sheibani $N$, Newman PJ, Frazier WA. Thrombospondin-1, a natural inhibitor of angiogenesis, regulates platelet-endothelial cell adhesion molecule-1 expression and endothelial cell morphogenesis. Mol Biol Cell 1997;8 (7):1329 41.

[43] Jimenez B, Volpert OW. Crawford SE, Febbraio M, Silverstein RL, Bouck N. Signals leading to apoptosis-dependent inhibition of neovascularization by thrombospondin-1. Nat Med 2000;6 (1):41 8 .

[44] Armstrong LC, Bornstein P. Thrombospondins 1 and 2 function as inhibitors of anglogenesis. Matrix Biol 2003:22 (1):63-71.

[45] Bikfalvi A. Platelet factor 4: an inhibitor of angiogenesis. Semin Thromb Hemost 2004;30 (3):379. 85. 
[46] van der Schaft DW. Dings RP, de Lussanell QG, van Eijk LI. Nap AW, Beets-Tan RG, Bouma-Ter

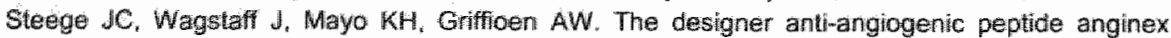
targets lumor endothelial cells and inhibits tumor growth in animal models. Faseb $d$ 2002;16 (14): $1991-3$.

[47] Bikfalvi A, Gimenez-Gallego $G$. The control of angiogenesis and tumor invasion by platelet factor-4 and platelet factor-4-derived molecules. Semin Thromb Hemost $2004 ; 30$ (1):137-44.

[48] van der Schaft DW, Toebes EA, Haseman JR, Mayo KH, Grifficen AW. Bactericidallpermeabilifyincreasing protein (BPI) inhibits angiogenesis via induction of apoptosis in wascular endathelial Cells, Bload 2000;96 (1):176-81.

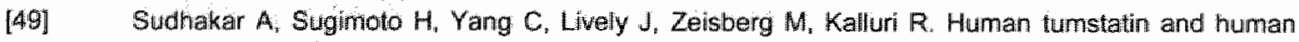
endostatin exhibit distinct antiangiogenic activities mediated by alpha $v$ beta 3 and alpha 5 beta 1 integrins. Proc Natl Acad Sci U S A 2003;100 (8):4766-71.

[50] Folkman d. Tumor angiogenesis: therapeutic implications. N Engl J Med 1971;285 (21):1182-6.

[51] Ferrara N. VEGF as a therapeutic target in cancer. Oncalogy 2005;69 Suppl 3:11-6.

[52] Scappaticci FA, Fehrenbacher L, Cartwright T, Hainsworth JD, Heim W, Berlin J, Kabbinavar $F$, Novotny $W$. Sarkar $S_{i}$ Hurwitz. H. Surgical wound healing complications in metastatic colorectal cancer patients treated with bevacizumab. J Surg Oncol 2005;91 (3):173-80.

[53] Kerbel RS. Inhibition of tumor angiogenesis as a strategy to circumvent acquired resistance to anticancer therapeutic agents. Bioessays 1991;13 (1):31-6.

154] Carmeliet $P$. Anglogenesis in life, disease and medicine. Nalure 2005 438 (7070):932-6.

[55] Miller KD. Sweeney C.J, Sledge GW, Jr. Can tumor angiogenesis be inhibited without resistance? Exs 2005 (94):95-112.

[56] Cahill DP, Kinzler KW, Vogelstein B, Lengauer C. Genetic instability and darwinian selection in tumours. Trends Cell Biol 1999;9 (12):M57-60.

[57] Wouters BG, van den Beucken T, Magagnin MG, Lambin P. Koumenis C. Targeting hypoxia tolerance in cancer. Drug Resist Updat 2004; 7 (1):25-40.

[58] Auguste $P$, Lemiere $S$, Larrieu-Lahargue $F$, Bikfalvi A. Molecular mechanisms of tumor vascularization. Crit Rev Oncol Hematol 2005;54 (1):53-61.

[59] Streubel $B_{n}$ Chott $A_{*}$ Huber $D$, Exmer M, Jager U, Wagner $O$, Schwarzinger I. Lymphoma-specific genetic aberrations in microvascular endothelial cells in B-cell lymphomas. N Engl J Med 2004;351 (3):250-9.

[60] Hida $K_{1}$ Hida $Y$, Amin DN, Flint AF, Panigrahy D, Morton CC, Klagsbrun M. Tumar-associated endothelial cells with cytogenetic abnormalities. Cancer Res 2004;64 (22):8249-55.

[61] Holash J, Davis S, Papadopoulos $N_{*}$ Croll SD, Ho L, Russell M, Boland P, Leidich R, Hylton D,

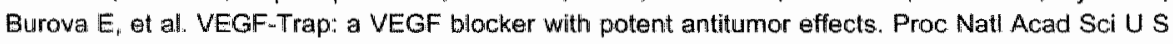
A $2002 ; 99(17): 11393-8$.

[62] Thomas AL, Morgan B, Horsfield MA, Higginson A, Kay A, Lee L, Masson E, Puccio-Pick $M_{*}$ Laurent D, Steward WP. Phase I study of the safety, tolerability, pharmacokinetics, and pharmacodynamics of PTKTB7/ZK 222584 administered twice daily in patients with advanced cancer. $\Perp \mathrm{Clin}$ Oncoll 2005:23(18):4162-71.

[63] Motzer R.J, Michaelson MD, Redman BG, Hudes GR, Wilding G, Figlin RA, Ginsberg MS, Kim ST, Baum CM. DePrimo SE, et al. Activity of SU11248, a multitargeted inhibitor of vascular endothelial growth factor receptor and platelet-derived growth factor receptor, in patients with melastatic renal cell carcinoma. J Clin Oncol 2006;24 (1):16-24.

[64] Gingras D, Boivin D, Deckers C, Gendron S, Barthomeuf C, Beliveau R. Neovastat-a novel antiengiogenic drug for cancer therapy. Anticancer Drugs 2003:14 (2):91-6.

[65] Maquoi E, Sounni NE, Devy L. Olivier F, Frankenne $F$, Krell HW, Grams F, Foidart JM, Noel A. Anti-invasive, antitumoral, and antiangiogenic efficacy of a pyrimidine-2,4,6-trione derivative, an orally active and selective matrix metalloproteinases inhibitor. Clin Cancer Res: 2004:10 (12 Pt 1): $4038-47$.

[66] Jones $\mathrm{PH}$, Christodoulos $\mathrm{K}$, Dobbs $\mathrm{N}$, Thavasu $\mathrm{P}$, Balkwill $\mathrm{F}$, Blann $A D$, Caine $G$, Kumar $S$, Kakkar $\mathrm{AJ}$, Gompertz $N$, et al. Combination antiangiogenesis therapy with marimastat, captopril and fragmin in patients with advanced cancer. Br a Cancer 2004:91 (1):30-6. 
Griffioen AW, van der Schaft DW, Barendsz-Janson AF, Cox A, Struigker Boudler HA, Hillen HF, Mayo KH. Anginex, a designed peptide that inhibits angiogenesis. Biochem $J 2001,354$ (PI 2),23342.

[68] Dings RP, van der Schaft DW, Hargittai $B$, Haseman J, Griffioen AW, Mayo KH. Anti-tumor activity of the novel angiogenesis inhibitor anginex. Cancer Lett 2003:194 (1):55-66.

[69] Dings RP, Williams BW, Song CW, Griffioen AW, Mayo KH, Griffin Ru. Anginex synergizes with radiation therapy to inhibit tumor growth by radiosensitizing endothelial cells. Int $J$ Cancer 2005:1 15 (2):312-9.

[70] Dings RP, Yokoyama $Y$, Ramakrishnan $S$, Griffioen AW, Mayo KH. The designed angiostatic peptide anginex synergistically improves chemotherapy and antiangiogenesis therapy with angiostatin. Cancer Res 2003;63 (2):382-5.

[71] Mayo KH, Dings RP. Flader C, Nesmelova I. Hargittai $B$, van der Schaft DW, van Eijk $L_{0}$ Walek $\mathrm{B}_{\text {, }}$ Haseman J, Hoye TR, et al. Design of a partial peptide mimetic of anginex with antiangiogenic and anticancer activity. J Biol Chem 2003;278 (46):45746-52.

[72] Brandwijk RJ, Nesmelowa I, Dings RP, Mayo KH, Thijssen VL, Griffioen AW. Cloning an artificial gene encoding angiostatic anginex: From designed peptide to functional recombinant protein. Biochem Biophys Res Commun 2005:333 (4):1261-8.

[73] Ahmed B, Van Eijk LI, Bouma-Ter Steege JC, Van Der Schaft DW, Van Esch AM, Joosten-Achjanie $\mathrm{SR}_{\mathrm{r}}$ Lambin $\mathrm{P}_{\mathrm{n}}$ Landuyt $\mathrm{W}$, Griffioen AW. Vascular targeting effect of combretastatin A-4 phosphate dominates the inherent angiogenesis inhibitory activity. Int J Cancer 2003;105 (1):20-5.

[74] El-Emir E, Boxer GM, Petrie IA, Boden RW, Dearling JL, Begent RH, Pedley RB. Tumour parameters affected by combretastatin A-4 phosphate therapy in a human colorectal xenograft model in nude mice. Eur J Cancer 2005:41 (5):799-806.

[75] Hayot C, Farinelle $S$, De Decker R, Decaestecker C, Darro F, Kiss R, Van Damme M. In vitro pharmacological characterizations of the anti-angiogenic and anti-tumor cell migration properties mediated by microtubule-affecting drugs, with special emphasis on the organization of the actin cytoskeleton. Int J Oncol 2002;21 (2):417-25.

[76] Folkman ل. Angiogenesis. Annu Rev Med 2006;57:11-18.

[77] Satchi-Fainaro R, Mamluk $R$, Wang $L$, Short SM, Nagy JA, Feng D, Dvorak. AM, Dvorak HF, Puder $M$, Mukhopadhyay $D$, et al. Inhibition of vessel permeability by TNP-470 and its polymer conjugate. caplostatin. Cancer Cell 2005; 7 (3):251-61.

[78] Jain RK. Normalization of tumor vasculature: an emerging concept in antiangiogenic therapy. Science 2005;307 (5706):58-62.

[79] Kerbel RS, Kamen BA. The anti-angiogenic basis of metronomic chemotherapy. Nat Rev Cancer 2004:4 (6):423-36.

[80] Zetter BR. Endothelial heterogeneily: Inffuence of vessel size, organ localization, and species specificity on the properties of cultured endothelial cells: CRC Press. Florida, 1988.

[81] McCarthy SA, Kuzu I, Gatter KC, Bicknell R. Heterogeneily of the endotheliel cell and its role in organ preference of tumour metastasis. Trends Pharmacal Sci 1991:12 (12):462-7.

[82] Aird WC. Endothelial cell heterogeneity. Crit Care Med 2003;31 (4 Suppl):5221-30.

[83] Aird WC. Endothelial cell heterogeneity: a case for nature and nurture. Blood 2004:103 (11):3994-5.

[84] Hillen F, Melotte V. van Beijnum JR, Griffioen AW. Endothellal cell biology. In: Staton CA, Lewis C,

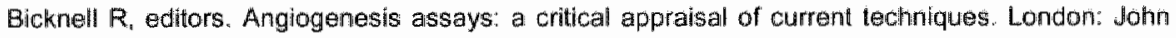
Wiley and Sons, in press.

[85] Tatsula T, Naito M. Mikami K, Tsuruo T. Enhanced expression by the brain matrix of P-glycoprotein in brain capillary endothelial cells. Cell Growth Differ 1994:5 (10):1145-52.

[86] Favre CJ, Mancusa M, Maas K, McLean JW, Baluk P. McDonald DM. Expression of genes involved in vascular development and angiogenesis in endothelial cells of adult lung. Am J Physiol Heart Circ Physiol 2003,285 (5):H1917-38.

[87] St Croix B, Rago C, Velculescu V. Traverso $G$, Romans KE, Montgomery $E$, Lal A, Riggins GJ, Lengauer $C$, Vogelstein $B$, et al. Genes expressed in human fumor endothelium. Science 2000;289 (5482):1197-202.

[88] Pasqualini R, Ruoslahti E. Organ targeting in wivo using phage display peptide libraries. Nature 1996;380 (6572):364-6. 
Rajotte D. Arap W, Hagedorn M. Koivunen E, Pasqualini $\mathbb{R}_{\varepsilon}$ Ruoslahti E. Molecular heterogeneity of the vascular endothelium revealed by in wivo phage display. J Clin Invest 1998; 102 (2):430-7.

[90] Pasqualini $\mathbf{R}_{\text {a }}$ Arap $W_{i}$ McDonald DM. Probing the structural and molecular diversity of tumor vasculature. Trends Mol Med 2002;8 (12):563-71.

[91] Ruoslahti E, Rajotte D. An address system in the vasculature of normal tissues and tumors. Annu Rev Immunol 2000:18:813-27.

(92) Pasqualinil $R$, Koivunen $E$, Ruoslahti $E$. Alpha $v$ integrins as receptors for fumor targeting by circulating ligands. Nat Biolechnol 1997, 15 (6):542-6.

[93) Pasqualini R, Koivunen E, Kain R, Lahdenranta J, Sakamoto M, Stryhn A, Ashmun RA, Shapiro LH. Arap $W, R u a s i a h i l E$. Aminopeptidase $\mathbb{N}$ is a receptor for tumor-homing peptides and a target for inhibiting angiogenesis. Cancer Res 2000;60 (3):722-7.

[94] Joyce JA, Laakkonen P, Bernasconi M, Bergers G. Ruoslahti E, Hanahan D. Stage-specific vascular markers revealed by phage display in a mouse model of pancreatic islet turnorigenesis. Cancer Cell 2003;4 (5):393-403.

[95] Jung YD, Ahmad SA, Liu W, Reinmuth N, Parikh $A$, Stoeltzing $O$, Fan $F$, Ellis LM. The role of the microenvironment and intercellular cross-talk in tumor angiogenesis. Semin Cancer Biol 2002;12 (2): 105-12.

[96] Chi JT, Chang HY, Haraldsen G, Jahnsen FL, Troyanskaya OG, Chang DS ${ }_{n}$ Wang $Z_{n}$ Rockson $S G$, van de Rijn $M$, Botstein $D_{i}$ et al. Endothelial cell diversity revealed by global expression profiling. Proc Natl Acad Sici U S A 2003;100 (19): 10623-8.

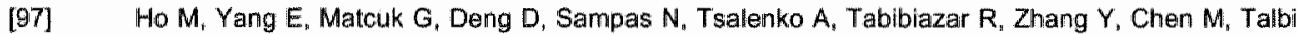
$S$, et al. Identification of endothelial cell genes by combined database mining and microarray analysis. Physiol Genomics 2003;13 (3):249-62.

[98] Lawson ND, Weinstein BM. Arteries and veins: making a difference with zebrafish. Nat Rev Genet $2002 ; 3(9): 674-82$.

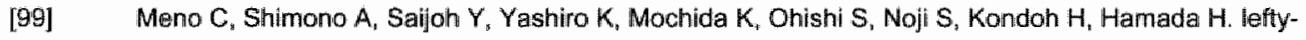
1 is required for left-right determination as a regulator of lefty-2 and nodal. Cell 1998;94 (3):287-97.

[100] Velculescu VE, Zhang L, Vogelstein B, Kinzler KW. Serial analysis of gene expression. Science $1995 ; 270(5235): 484-7$.

[101] Diatchenka L, Lau YF, Campbell AP, Chenchik A, Mogadam F, Huang B, Lukyanov S, Lukyanov K, Gurskaya N, Sverdlov ED, el al. Suppression subtractive hybridization: a method for generating differentially regulated or tissue-specific cDNA probes and libraries. Proc Natl Acad Sci U S A 1996;93 (12):6025-30.

[102] Schena $M$, Shalon D, Dawis RW, Brown PO. Quantitative monitoring of gene expression patterns with a complementary DNA microarray. Science $1995 ; 270(5235): 467-70$.

[103] Goldenberg MM. Trastuzumab, a recombinant DNA-derived humanized monoclonal antibady, a novel agent for the treatment of metastatic breast cancer. Clin Ther 4999;21 (2):309-18.

[104] Neri D, Bicknell R. Tumour vascular targeting. Nat Rev Cancer 2005;5 (6):436-46.

[105] Work LM, Buning $H$. Hunt E, Nicklin SA, Denby L, Britton $N$, Leike $K_{s}$ Odenthal M. Drebber $U$, Hallek $\mathrm{M}_{*}$ et al. Vascular bed-targeted in vivo gene delivery using tropism-modified adenoassociated viruses. Mol Ther 2005.

[106] Nicklin SA, Reynolds. PN, Brosnan MJ, White SJ, Curiel DT, Dominiczak AF, Baker AH. Analysis of cell-specific promoters for viral gene therapy targeted at the vascular endothelium. Hypertension 2001;38(1):65-70.

[107] van Beinum JR, Eijgelaar WJ, Griffioen AW. Towards high-throughput functional target discovery in angiogenesis research. Trends Mol Med 2005.

[108] Burrows FJ, Thorpe PE. Eradication of large solid tumors in mice with an immunotoxin directed against tumor vasculature. Proc Natl Acad Sci U S A 1993;90 (19):8996-9000.

[109] Sullivan DC, Huminiecki L, Moore JW, Boyle JJ. Poulsom R, Creamer D, Barker J. Bicknell R. EndoPDI, a novel protein-disulfide isomerase-like protein that is preferentially expressed in endothelial cells acts as a stress survival factor. J Biol Chem 2003;278 (47);47079-88.

[110] Huminiecki L. Bicknell R. In silico cloning of novel endothelial-specific genes. Genome Res 2000;10 (11): 1796-806. 
[111] Zardi L, Camemolla $B$, Siri A, Petersen TE. Paolella G, Sebastio G, Baralle FE. Transfomed human cells produce a new fibronectin iscorm by preferential alternative splicing of a previously unobserved exon. Embo J 1987;6 (8):2337-42.

[112] Santimaria M, Moscatelli $G$, Viale GL, Giovannoni L, Neri G, Viti F, Leprini A, Borsi L, Castellani P. Zardi $L$, et al. Immunoscintigraphic detection of the ED-B domain of fibronectin, a marker of angiogenesis, in patients with cancer. Clin Cancer Res 2003;9 (2) 571-9.

[113] Borsi L, Balza E, Bestagno M, Castellani $P$, Carnemolla B, Biro A, Leprini A, Sepulveda ل, Burrone $O$. Neri $D$, et al. Selective targeting of tumoral vasculature: comparison of different formats of an antibody (L19) to the ED-B domain of fibronectin. Int J Cancer 2002;102 (1):75-85.

[114] MacFadyen JR, Haworth O, Roberston D. Hardie D, Mebster MT, Morrls HR, Panico M, SuttonSmith $M$, Dell $A$, van der Geer $P$, et al. Endosialin (TEM1, CD248) is a marker of stromal fibroblasts and is not selectively expressed on tumour endothelium. FEBS Lett 2005;579 (12):2569-75.

[115] Duesbery NS, Resau J, Webb CP, Koochekpour S, Koo HM, Leppla SH, Vande Woude GF. Suppression of ras-mediated transformation and inhibition of tumor growth and angiogenesis by anthrax lethal factor, a proteolytic inhibitor of multiple MEK pathways. Proc Nati Acad Sci U S A 2001;98 (7):4089-94.

[116] Oh P, Li Y, Y'u J, Durr E, Krasinska KM, Carver LA, Testa JE, Schnitzer JE. Subtractive proteomic mapping of the endothelial surface in lung and solid tumours for tissue-specific therapy. Nature 2004;429 (6992):629-35.

[117] Rybak JN, Ettorre A, Kaissling B, Giavazzi R, Neri D, Elia $G$. In vivo protein biotinylation for identification of organ-specific antigens accessible from the vasculature. Nat Methods 2005;2 (4):291-8.

[118] Wang JL, Liu YH, Lee MC, Nguyen TM, Lee C, Kim A, Nguyen M. Identification of tumor anglogenesis-related genes by subtractive hybridization. Microvasc Res 2000;59 (3):394-7.

[11:9] Zhang $H-T$, Gorn M, Smith K, Graham AP, Lau KKW, Bicknell R. Transcriptional profiling of human microvascular endiothelial cells in the proliferative and quiescent state using cDNA arrays. Angiogenesis 1999;3:211-9.

[120] Abe M, Sato $Y$, CDNA microarray analysis of the gene expression profile of VEGF-activated human umbilical vein endothelial cells. Angiogenesis $2001 / 4$ (4):289-98.

[121] Jih YJ, Lien WH, Tsai WC, Yang GW, Li C, Wu LW. Distinct regulation of genes by bFGF and VEGF-A in endothelial cells. Angiogenesis 2001:4 (4):313-21.

[122] Gerritsen ME, Tomlinson JE, Zlot $C$, Ziman M, Hwang S. Using gene expression profiling to identify the molecular basis of the synergistic actions of hepatocyte growth factor and vascular endothelial growth factor in human endothelial cells. Br J Pharmacol 2003;140 (4):595-6.10.

[123] Aitkenhead M, Wang SJ, Nakatsu MN, Mestas $J$, Heard C. Hughes CC. Identification of endothelial cell genes expressed in an in vitro model of angiogenesis: induction of ESM-1, (bota)ig-th3, and NrCAM. Microwasc Res 2002;63 (2):159-71.

[124] Bell SE, Mavila A, Sallazar R, Bayless KJ, Kanagala S, Maxwell SA, Davis GE. Differential gene expression during capillary morphogenesis in 3D collagen matrices: regulated expression of genes inwolved in basement membrane matrix assembly, cell cycle progression, cellular differentiation and G-protein signaling. J Cell Sci 2001:114 (Pt 15):2755-73.

[125] Gerritsen ME, Soriano R, Yang $S$, Zlot C, Ingle G, Toy K, Willams PM. Branching oul: a molecular fingerprint of endothelial differentiation into tube-like structures generated by affymetrix oligonucleotide arrays. Microcirculation 2003;10 (1):63-81.

[126] Kahn J, Mehraban F, Ingle G, Xin X, Bryant JE, Vehar G, Schoenfeld J, Grimaldi C., Peale $F$.

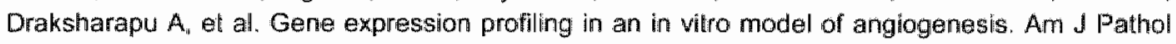
2000:156 (6):1887-900.

[127] Wary KK. Thakker GD, Humtsoe JO, Yang J. Analysis of VEGF - Fesponsive Genes Involved in the activation of endothelial cells. Mol Cancer 2003:2 (1):25.

[128] Parker BS. Argani P, Cook BP, Liangfeng $H$, Chartrand SD, Zhang M, Saha S, Bardelli A, Jiang $Y$, St Martin TB, et al. Alterations in vascular gene expression in invasive breast carcinoma. Cancer Res 2004:64 (21):7857-66.

[129] Madden SL, Cook BP, Nach M, Weber WD, Callahan MR, Jiang $Y$, Dufault MR, Zhang $X$, Zhang $W$, Walter-Yohrling $J_{i}$ et al. Vascular gene expression in nonneoplastic and malignant brain. Am $J$ Pathol 2004:165 (2):601-8. 


\section{Chapter 2}

\section{In silico analysis of angiogenesis associated gene expression identifies angiogenic stage related profiles}

Judy R. van Beijnum \& Arjan W. Griffioen

Biochim Biophys Acta. 2005 Jul 25;1755(2):121-34 


\section{> Abstract}

In vitro models have been extensively used to map gene expression in EC but few studies have used cells from in vivo sources directly. Here, we compare different gene expression surveys on both cultured and fresh tissue derived EC, and it emerges that gene expression profiles can be paralleled with the angiogenic stage of the cells. EC stimulated with different growth factors in monolayer cultures exhibit gene expression profiles indicative of an active proliferative state, whereas gene expression in tube forming cells in vitro involves genes implicated in cell adhesion processes. Genes overexpressed in tumor EC are biased towards ECM remodeling, a late event in angiogenesis. The elucidation of gene expression profiles under these different conditions will contribute to a better understanding of the molecular mechanisms during angiogenesis in both pathological and physiological circumstances and will have implications for the development of angiogenesis interfering treatment strategies. 


\section{$>$ Introduction}

\section{Endothelial cell biology and angiogenesis}

Endothelial cells (EC) are among the most quiescent cells of the body since their turnover rate can be up to hundreds of days. However, during the growth of new capillaries from pre-existing blood vessels (angiogenesis), activated EC can proliferate as rapidly as bone marrow cells [1], highlighting their capacity to readily respond to microenvironmental changes. Angiogenesis is in essence a physiological phenomenon and is a hallmark of processes such as wound healing, embryonic development, tissue remodeling and the female reproductive cycle ${ }_{n}$ in which tissue growth is essential. However, angiogenesis also occurs during pathological conditions such as diabetic retinopathy, rheumatoid arthritis and cancer. The role of angiogenesis in the progression of cancer has gained particular interest once it became clear that the growth, invasion and metastasis of tumors are dependent on the formation of blood vessels [2]. In addition to providing a metastatic route, the vasculature provides the indispensable metabolic support for the tumor. Without adequate blood supply, the size of tumors is limited due to deprivation of oxygen and nutrients in the tumor cell mass. In response to these limitations tumors start to produce angiogenic factors that activate EC to initiate sprouting from nearby pre-existing vessels [2]. The genetic change of tumor cells, leading to the formation of tumor vasculature, is referred to as the angiogenic switch $[1,3]$. In the tumor microenvironment, both anti-angiogenic and proangiogenic factors are expressed, and angiogenesis is induced once the balance tips over in favor of the latter. The expression of pro-angiogenic factors can be induced by hypoxia, and also by oncogene activation or tumor-suppressor gene mutations; the relative contribution of these events is likely to be determined by the specific type and location of the tumor $[3,4]$. A variety of endothelial growth factors have been described, among which vascular endothelial growth factors (VEGFs) [5], fibroblast growth factors (FGFs) [6], hepatocyte growth factor (HGF) [7] and the angiopoietins [8].

Once angiogenesis is induced, a sequence of events is set in motion. Angiogenic sprouting comprises (i) local degradation of the basement membrane and ECM surrounding the capillaries, (ii) migration of EC in the direction of the tumor mass, (iii) proliferation of EC, (iv) differentiation and ( $V$ ) subsequently the formation of tube-like structures, in which attraction of pericytes and smooth muscle cells and deposition of new ECM occurs. During the final stages, the ECM is remodeled, and sprouts will fuse with each other to create a circulation $[4,9]$.

Tumor progression is highly dependent on the development of a tumor vasculature by angiogenic sprouting. The precise requirements of tumors, however, may wary among different tumor types and during tumor progression. Hence, tumor phenotype heterogeneity dictates tumor vasculature heterogeneity [4]. It has been recognized that tumor vessels are irregularly shaped, tortuous and often leaky. Under normal conditions, vessel density is tightly controlled and newly formed vessels rapidly mature, but the aberrant balance of angiogenic factors produced in malignancies result in a 
chaotic tumor vasculature [4]. Tumor vessells fail to become quiescent; therefore, tumors have been described as "wounds that never heal" [10].

\section{Angiogenesis inhibition}

Given the observation that most tumors are angiogenesis dependent, both for metabolic support and for metastatic dissemination, inhibition of angiogenesis is thought to be a promising strategy for the treatment of solid tumors [11], and likely hematological malignancies as well $[12,13]$. The concept of angiogenesis inhibition for cancer treatment has gained much attention over the past years and a number of different strategies have been employed, based on knowledge of EC biology and behavior during angiogenesis. To this purpose, synthetic agents have been developed that act on EC, a number of endogenous proteins and peptides with anti-angiogenic actions have been discovered, but also the use of antibodies to interfere with the angiogenesis process has been explored.

In addition to interfering with the unwanted de novo formation of blood vessels, targeting existing tumor blood vessels for destruction resulting in tumor regression (vascular targeting), may also hold promise. EC express genes that are not or to a lower extent expressed by other cell types $[14,15]$ and this may offer the possibility of using gene products that are specific for a certain subset of EC for targeting purposes. It has been shown that EC exhibit differences in gene and protein expression, relating to their microenvironmental origin and activation status $[16,17]$.

Tumor blood vessels express specific markers that are not present on normal blood vessels and these markers can be present on the EC themselves, on pericytes and on the ECM [18]. By in vivo phage display selections, it was demonstrated that EC express 'address molecules' that differ according to their location in the body and their specific signature $[19,20]$. A phage-displayed peptide that specifically bound to tumor vasculature contained an RGD sequence (arginine-glycine-aspartic acid), known to bind integrins aVp3 and aVP5 [20]. Another tumor vasculature specific peptide, containing the NGR sequence (asparagine-glycine-arginine), was shown to bind aminopeptidase $N$, also known as CD13 [21]. Although this protein is also expressed in severall epithelial tissues and macrophages, the cyclic NGR peptide does not bind to these cells, indicating a specific form of aminopeptidase $\mathrm{N}$ is present on angiogenically activated EC [22]. Other markers that are upregulated on tumor EC include prostatespecific membrane antigen (PSMA) [23], CD44 [16], endoglin [24] and the oncofetal ED-B domain of fibronectin [25], whereas CD34 and intercellular adhesion molecule 1 (ICAM1) are suppressed $[17,26]$.

Probably the most crucial element in both anti-angiogenic and vascullar targeting approaches is the identification of specific target molecules. Since angiogenesis is not limited to pathological conditions, careful evaluation of the putative targets is warranted to prevent side effects associated with impaired physiological angiogenesis. Gene expression studies can be very helpful tools in elucidating the transcriptional differences between EC of different sources and to identify tissue or tumor endothelial 
specific markers. Furthermore, gene expression analysis in this context will lead to a better understanding of EC biology during (tumor) angiogenesis. Different models have been developed to study angiogenesis, but the temporal and spatial complex actions of all factors exerting effect on EC in vivo may not be accurately reflected in witro.

Here we will overview different studies that used large-scale gene expression profiling of $\mathrm{EC}$ in different stages of angiogenic activation in vitro and in vivo. Gene expression changes associated with the different stages of angiogenesis that emerge from these studies are discussed and related to their potential use in the development of angiogenesis inhibitors or vascular targeting agents.

\section{> Gene expression profiling in angiogenesis research}

\section{Expression profiling techniques}

Large-scale gene expression profiling techniques are widely used to detect changes in transcript expression levels and provide the tools to study molecular events in biological processes. For the comparison of two or more cell types, a number of techniques have been developed and employed. Serial analysis of gene expression (SAGE) provides a quantitative analysis of large numbers of transcripts, based on sequence analysis of short specific, concatenated tags. Multiple direct comparisons are possible by assessing the frequencies at which transcripts are present in the libraries [27]. Another technique, suppression subtractive hybridization (SSH) combines an effective cDNA subtraction between two samples with the requirement of only limited amounts of starting material and is, like SAGE, independent of previously cloned genes and existing sequence information [28]. SSH can be used in combination with cDNA arrays to screen for differentially expressed genes [29]. cDNA can be spotted on nylon filters for hybridization with radioactively labeled probes, usually referred to as macroarrays due to their relatively low spot density and their large size. Sequential hybridization of different samples to identical arrays allows for comparison of gene expression in the different probes.

Differential display provides a systematic and unbiased procedure to detect differences in MRNA species [30] and GeneCalling ${ }^{T /}$ is a modification of this technique. Double-stranded CDNA is digested with pairs of restriction enzymes, amplified with specific linkers and resolved on polyacrylamide gel. Based on fragment length and the combination of restriction enzymes used, transcripts are identified using sophisticated database searches [31].

The advent of microarray technology has boosted gene expression profiling research [32]. High-density robotic printing of thousands of cDNAs on glass slides and subsequent two-color fluorescent hybridization and detection allows for a quantitative comparison of genes in complex probe mixtures [32]. Oligonucleotide arrays are a variation on the theme of microarrays. Complex probes of one experimental sample at the time are hybridized and signal intensities are measured by scanning [33]. A. 
limitation of the latter techniques is that they rely fully on known sequences, but ongoing efforts to characterize and annotate the human genome are likely to enable screening the majority of expressed transcripts in the near future. Furthermore, data management and analysis are key to success when using these large-scalle gene expression profiling techniques [34]. Clustering analysis can help identify coordinately regulated genes that are likely to be functionally related in the applied experimental conditions [35]. All of these techniques have their own advantages and disadvantages related to scale, effort, cost and availability of sample material. Furthermore, techniques can be combined to enhance sensitivity or throughput.

\section{In silico profiling of EC}

The avallability of public gene expression data sets has opened additional doors for gene expression profiling studies. By using different bioinformatics tools to query existing databases, it is possible to identify genes that are expressed in a particular cell type $[14,15]$ or to overlap data sets to identify genes that are co-regulated under different circumstances [36]. In silico comparison of existing data sets may also be helpful in the elucidation of gene expression on tumor endothelium. Available databases of gene expression profiles in EC can be overlapped with expression profiles of tumors to identify commonly regulated genes [36,37]. A minor drawback of this approach might be that only limited gene expression data of EC from in vivo sources is availlable to date. Also, formats need to be interchangeable for easy data transfer and data analysis.

In this review, we analyze published data sets of genes induced in growth factor stimulated and tube forming EC in vitro, as well as from EC isolated from tumor tissues. Gene expression profiles of EC treated with bFGF, VEGF, HGF, epidermal growth factor (EGF) and different combinations thereof are reviewed and common pathways identified that play key roles in the initial activation of EC. Differentiation of EC in tube-like structures can be accomplished by providing three-dimensional (3D) support, leading to the induction of genes associated with this process. Finally, genes identified to be overexpressed on tumor EC of different types of tumors are discussed. This method allows filtering out interesting candidate genes amenable for interference in angiogenic events in different stages of progression, and can provide tools to define therapeutic agents to perform these tasks.

Gene expression associated with cytokine and growth factor stimulation of EC in witro

Gene expression profiling has been applied to EC treated with different proangiogenic cytokines in various models to elucidate genes involved in angiogenesis. SSH in combination with differential screening was used to study transcriptional changes in human umbilical vein EC (HUVEC) cultured for 4 hours in the presence of tumor conditioned medium (CM) from the mellanoma cell line C8161 and the breast cancer cell line MDA-MB231 that contain high levels of angiogenic stimulators [38]. Twenty genes were confirmed to be upregulated, some of which had previously been 
associated with angiogenesis, e.g. E-selectin [39] and fibronectin [40]. Cytokines associated with angiogenesis that were identified in this study included monocytechemoattractant protein-1 (MCP-1) [41] and interleukin-8 [42]. One of the most interesting candidate genes for follow-up was endomucin. Endomucin is a highly glycosylated transmembrane protein expressed predominantly on vascular EC [43] and high endothelial venules, where it can function as a ligand for $\mathbb{L}$-selectin [44]. Its expression seems to correlate with $\mathbb{E C}$ proliferation as it is increased upon stimulation with bFGF, tumor necrosis factor $\alpha$ (TNF $\alpha$ ) and under the influence of tumor CM [43]. Due to its elevated expression in angiogenically activated EC and its cell surface localization, endomucin might be a putative tumor endothelium targeting candidate. However, it remains to be determined whether a sufficiently large therapeutic window can be created for therapies not to interfere with endomucin expressed on non-tumor EC. Furthermore, although the authors state that this in vitro model provides an accurate stimulation of the tumor environment, one can question whether 4 hours of stimulation with tumor-derived factors is sufficient for EC to adopt a tumor endothelial phenotype since tumor initiation and progression is a relatively slow process.

By using HUVEC cultured for three days in the presence of bFGF, VEGF and supernatant of two colorectal tumor cell lines, Caco-2 and LS174T, we created SSH repertoires that were used for macroarray screening. Twenty different genes were identified that showed upregulation in both tumor derived EC when compared to normal EC (isolated from fresh tissues) and in HUVEC cultured in the above mentioned conditions compared to quiescent HUVEC [45]. Functional annotation of the identified transcripts showed that most genes were indicative of a high proliferative status of the $E C$, since more than one third of these genes are involved in protein turnover and metabolism such as ribosomal proteins L21 and S27, and HSP90. Furthermore, a number of genes have previously been associated with angiogenesis " such as thymosin $\beta 4$, matrix metalloproteinase (MMP) 10 and integrin $\beta 1$. Thymosin $\beta 4$ is implicated in EC migration, proliferation and differentiation by interfering with actin polymerization [46]. Exoglenously applied, it acts as a chemoattractant for $E C$, stimulates migration, increases MMP production [47] and induces tube formation and sprouting $[46,48]$. The most interesting aspect of thymosin $\beta 4$ is therefore that it affects EC biology both as endogenous and exogenous peptide, creating ample opportunities for modulating EC function.

A comparison of quiescent versus proliferating EC stimulated with EGF by cDNA array revealled a large proportion of genes associated with cell cycle regulation to be upregulated in proliferating human dermal microvascular EC (HDMEC) [49]. Various cyclins were induced, among which G1/S specific cyclins D1 and D2 and the mitosis specific cyclins B1 and $G$. Increased expression of cyclin D1 in response to VEGF and bFGF has later been reported [50]. Furthermore, cyclin D1 expression has been shown to be downregulated in EC by the anti-angiogenic agent TNP-470 [51] and the endogenous angiogenesis inhibitor endostatin [50]. Endostatin induces cell cycle arrest in G1, associated with an inhibition of hyperphosphorylation of $\mathrm{Rb}$ protein and $\mathrm{a}$ 
downregulation of cyclin D1 promoter activity [50]. However, forced overexpression of cyclin D1 in EC overrides the effect of endostatin [50]. The study by Zhang et al. [49] also confirmed the upregulation of the known angiogenesis stimulators interleukin-8, TIE-1 and TIE-2 in activated EC. Furthernore, it stressed the involvement of different integrin subunits ( $\alpha \mathrm{V}, \alpha 5, \alpha 6$ and $\beta 1)$ in $\mathrm{EC}$ adhesion and tumor angiogenesis $[52,53]$. As discussed earlier, integrins pose interesting candidate molecules for interference in angiogenesis $[54,55]$. Connective tissue growth factor (CTGF) was also upregulated in HDMEC in response to EGF and belongs to the CCN family of matricellular proteins. Several members of this family are positively unvolved in angiogenesis and their activities are mediated by integrins and by the induction of MMP expression $[56,57]$. CTGF (CCN2) and CYR61 (CCN1) are transcriptionally activated in EC by bFGF and VEGF and are capable of promoting EC growth, migration, adhesion and survival. Furthermore, these proteins can act in a paracrine or autocrine fashion by upregulating the endothelial growth factors VEGF and bFGF [58]. CCN proteins have been recognized to be important regulators in angiogenesis during wound healing, placenta formation, fibrosis and tumor growth [58], hence attempts to interfere in the complex actions of these proteins with the aim of inhibiting tumor angioglenesis may turn out to be difficult.

Microarray analysis was used to identify genes induced by VEGF at different time points in HUVEC [59]. Over a period of 24 hours, 139 genes showed induction by VEGF, of which 53 were induced within the first two hours of VEGF stimulation. From this analysis it was apparent that a number of genes show peak expression at early time points and reduce their expression to basal levels within 12 hours after stimulation with VEGF. Among the genes upregulated within 30 minutes were 3 transcription factors (early growth response (EGR) 1, EGR2 and EGR3) and 10 genes associated with cellular support, involved in metabolism, protein turnover and protein transport. Five known positive regulators of angiogenesis were identified: cyclooxygenase-2 (COX-2), heparin-binding epidermal growth factor-like growth factor (HBEGF). EGR1, CYR61 and angiopoietin-2. Induced by cytokines, COX-2 catalyzes the production of prostaglandins from arachidonic acid [60]. COX-2 metabolites promote Rac1 and CDC42 activation resulting in integrin $\alpha$ VB3-mediated cell spreading and migration [61]. Furthermore, COX-2 inhibitors such as non-steroidal anti-inflammatory drugs (NSAIDs), have a protective role against the development of cancer [62], and this effect is partly due to diminished tumor angiogenesis via the inhibition of $\alpha$ V $\beta 3$ mediated Rac1 activation [52,63]. HBEGF has been associated with the induction of tube-like structures of EC in type $\|$ collagen [64] and increased tumorigenicity associated with increased angiogenic potential [65]. EGR1 is a key transcription factor in EC and mediates the VEGF induced upregulation of tissue factor, platelet-derived growth factor (PDGF) and transforming growth factor- $\beta$ (TGF- $\beta$ ), as well as the transcription of membrane type 1 MMP (MMP14), facilitating the invasion of EC into the surrounding matrix [66]. Growth factor induced EGR1 transcriptional activity is inhibited 
by the NGFI-A binding protein 2 (NAB2) corepressor as well as by NSAIDs, the latter further explaining the observed protective role of these drugs [67].

A survey of genes regulated by VEGF, bFGF and the combination of both revealed only a partial overlap in expression profiles of HUVEC [68]. Interestingly, the combination of bFGF and VEGF induced a number of VEGF receptors, whereas the administration of VEGF alone failed to do so. Various cyclins and cyclin-dependent kinases were induced by the different treatments [68]. Furthermore, EGR1 was identified to be induced by the combination of bFGF and VEGF, in contrast to the finding of Abe et al. [59] who identified this transcription factor to be upregulated by treatment with VEGF alone. It is interesting to note that bFGF treatment regulated the expression of the oncogenic transcription factors myc, jun and fos [68]. Induction of oncogenes was also observed in bFGF transformed EC [69], suggesting a specific trait of bFGF action.

Relatively little overlap was also observed when the expression profiles of HUVEC treated with HGF, with VEGF, and with a combination of both were compared [70]. In addition, few genes were coordinately regulated after 4 hours and 24 hours of VEGF treatment. The importance of the above-mentioned key angiogenesis transcription factor EGR1 is underscored by the fact that both combination treatments (bFGF+VEGF and HGF+VEGF) induced its expression, evident already 1 hour and 4 hours following growth factor treatment, respectively $[68,70]$.

The above described studies used cultured EC stimulated with different growth factors as models for angiogenesis. It appears, however, that only a few genes are commonly regulated during growth factor stimulation of EC (Table 2.1). Components of the mitogen-activated protein kinase (MAPK) signaling pathway (jun, myc, MAP2K3) and cytokine signaling components (FIt1, IL-8, IL6ST, CCL2, TEK) were distinctly present, as were different cell cycle mediators (MCM2, CDC20, CCND2). Different effects on gene expression profiles by different growth factors and their combination was also evident in the studies performed by Gerritsen et al. [70] and Jih et al. [68], indicating largely separate signaling pathways are mediating the responses. Furthermore, different time points were analyzed which can have considerable effect on the identification of early acting genes and transcription factors that activate secondary genes. The gene expression platforms and data analysis in the above discussed studies differ considerably, creating additional bias. Further contributing to the observed differences can be the diversity of the EC used in the above described studies. EC of macrovascular origin, such as HUVEC $[38,59,68,70]$, have recently been shown to differ substantially from microvascular EC, such as HDMEC [49], by large scale gene expression profiling [71]. These differences are supposed to support local specialization of the vascular beds and consequently contribute to inherent differences in expression patterns. 
Table 2.1: Growth factor regulation of common players in in vitro modells of angiogenesis

\begin{tabular}{|c|c|c|c|c|c|}
\hline Function Deseription & Gente & Ungene HD & \multicolumn{2}{|c|}{ Growth factor regulation } & References \\
\hline \multicolumn{6}{|c|}{ Cell cycle regulators and apoptosis retater proleing } \\
\hline \multicolumn{6}{|l|}{ 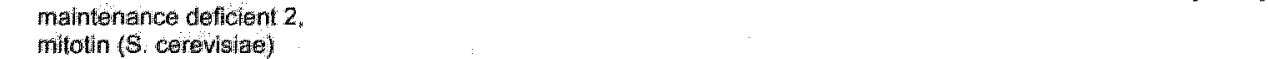 } \\
\hline \multicolumn{6}{|l|}{$\begin{array}{l}\text { CDC20 cell division cycle } 20 \\
\text { homolog (s. creverisiale) }\end{array}$} \\
\hline \multirow{2}{*}{$\begin{array}{l}\text { Cychin D2 } \\
\text { DHA-dange-inducible } \\
\text { trangcript } 3\end{array}$} & $\mathrm{CCND2}$ & $\mathrm{HS.376071}$ & $E G F$ & DFGF+VEGF & {$[49,68]$} \\
\hline & DLIT3 & Hs 370771 & EGF & bFGF+VEGF & {$[49,68]$} \\
\hline $\begin{array}{l}\text { Cyclin-dependem kinase } \\
\text { inhibitor } 1 \mathrm{~A} \text { (p21, Cip1) }\end{array}$ & CDKNNAA & $H s .505777$ & VEGF & bFGF + VEGF & {$[59,68]$} \\
\hline Calspalse 3 & CASP3 & Hs. 141125 & VEGF & EGF & 49,68 \\
\hline \multicolumn{6}{|l|}{ Extracillular matrix proteins } \\
\hline $\begin{array}{l}\text { Serine (ar cysteme) proteinase } \\
\text { inibilittor clade } \mathrm{B} \text {, member } 2 \\
\end{array}$ & SERPINB2 & Hs.514913 & VEGF & VEGF+HGF & {$[59,68]$} \\
\hline \multicolumn{6}{|c|}{ Growth factors, cytokines and hormones } \\
\hline \multirow{4}{*}{$\begin{array}{l}\text { Angiopoietin } 2 \\
\text { Chemokine (C-C motif) ligand } 2 \\
\text { Interleukin } B \\
\text { Diphtheriat toxin neceptor (HB- } \\
\text { EGF-like growth factor) }\end{array}$} & ANGPT2 & His.549021 & VEGF & VEGF+HGF & {$[59,70]$} \\
\hline & COL2 & $\mathrm{Hs.303649}$ & $\mathrm{CM}$ & WFGF +VEGF & {$[38,68]$} \\
\hline & 168 & $\mathrm{Hs.624}$ & VEGF & EGF $\mathrm{CM}$ & {$[38,49,68]$} \\
\hline & HBEGF & $\mathrm{Hs} .799$ & VEGF & & {$[59,68]$} \\
\hline \multicolumn{6}{|l|}{ Metabolism } \\
\hline \multirow{2}{*}{$\begin{array}{l}\text { Prostaglandin-endoperoxide } \\
\text { synthase } 2 \text { (Cox-2) } \\
\text { Superoxide dismutase 2, } \\
\text { mitochondrial }\end{array}$} & PTGS2 & Hs. 196384 & CM & VEGF & $\llbracket 38,59\rfloor$ \\
\hline & SOD2 & $\mathrm{Hs} .487046$ & $\mathrm{CM}$ & $\mathrm{DFGF}+\mathrm{VEGF}$ & {$[38,68]$} \\
\hline \multicolumn{6}{|c|}{ Proteim turnower, modification and transport } \\
\hline \multirow{2}{*}{\multicolumn{2}{|c|}{$\begin{array}{cc}\text { Alpha-2-macroglabulin } & \text { A2M } \\
\text { Cell surfiace proteins, antigens, receptors and adh }\end{array}$}} & $H \mathbb{\$}, 212838$ & VEGF & VEGF+HGF & 59,70 \\
\hline & & \multicolumn{4}{|c|}{ Cell surfiace proteins, antigens, receptors and adhesion molecules } \\
\hline \multicolumn{2}{|c|}{$\begin{array}{l}\text { Low densily lipopratein } \\
\text { receptar }\end{array}$} & Hs.2113289 & VEGF & VEGF+HGF & {$[5970]$} \\
\hline AXL receptor tyrosine kinase & AXL & $\mathrm{Hs.4667911}$ & $\mathrm{CM}$ & bFGF+VEGF & {$[38,68]$} \\
\hline Integrin aV & ITGAV & Hs. 4368873 & EGF & VEGF & {$[49,68]$} \\
\hline Integrin $B 3$ & ITGB3 & $H s .218040$ & EGF & $\mathrm{bFGF}$ & {$[49,68]$} \\
\hline $\begin{array}{l}\text { TEK tyrosine kinase, } \\
\text { endothellall }\end{array}$ & TEK & Hs. 89640 & EGF & DFGF+VEGF & {$[49,68]$} \\
\hline $\begin{array}{l}\text { Tyrosine kinase with lig-like } \\
\text { and EGF-like domalins t }\end{array}$ & TIE & $\mathrm{Hs} .788024$ & EGF & DFGF+VEGF & {$[49,68]$} \\
\hline Thrombonodulin & $\pi H B D$ & $\mathrm{H}: 2030$ & VEGF & VEGFHHGF & {$[59,68,70]$} \\
\hline $\begin{array}{l}\text { Interlaukin } 6 \text { signal irranseducer } \\
\text { (gp1 } 130, \text { oncostatin M receptor) }\end{array}$ & ILST & $\mathrm{Hs} .532082$ & VEGF & WEGF+HGF & {$[68,70]$} \\
\hline \multirow{2}{*}{$\begin{array}{l}\text { Frnswralated tyrosine kinase } 1 \\
\text { (VEGE receptor) } \\
\text { lntegrin } a 6\end{array}$} & FLTH & $H s .507624$ & $\mathrm{bFGF}+\mathrm{VEGF}$ & VEGF+HGF & {$[68,70]$} \\
\hline & ITGAG & Hs. 133397 & $\begin{array}{l}\text { BFGF+VEGF } \\
\text { EGF }\end{array}$ & VEGF+HGF & {$[49,68,70]$} \\
\hline \multicolumn{6}{|l|}{ Signal transduction proteins } \\
\hline $\begin{array}{l}\text { Mitogen-gctivated protein } \\
\text { kirbase kinasa } 3\end{array}$ & MAP2K3 & $4 \mathrm{~s} .514012$ & bFGF & VEGF+HGF & {$[68,70]$} \\
\hline \multicolumn{6}{|c|}{ Tramscription factors and chromatin associated proteins } \\
\hline Earfly growth response 1 & EGR\| & $H 15.326035$ & $\begin{array}{l}\text { bFGF+VEGF } \\
\text { VEGF }\end{array}$ & VEGF+HGF & {$[59,68,70]$} \\
\hline $\begin{array}{l}\text { Vujun sarcomv viris } 17 \\
\text { oncogene homolog (avian) }\end{array}$ & JUN & Hs. 525704 & bFGF & $\mathrm{EGF}$ & {$[49,68]$} \\
\hline
\end{tabular}

When reviewing the functional classification rather than the identity of the genes reported to be upregulated in the six studies discussed, it emerges that cell cycle related genes make up the larger part of regulated genes, followed by genes 
associated with metabolism (Figure 2.1A). Such a 'cell cycle signature' of upregulated genes can be related to the transition from quiescent to proliferative EC under the influence of these growth factors, an early event in angiogenesis.

\section{Gene expression associated with tube formation of $E C$ in vitro}

EC grown in collagen type 1 gels form tube structures in vitro. During this differentiation process, changes in gene expression are evident. $A$ time course of gene expression during capillary morphogenesis in 3D collagen matrices was studied using microarrays to compare expression profiles of HUVEC at 0, 8, 24 and 48 hours [72]. Extracellular matrix components comprised the most abundant functional class of genes upregulated during capillary formation in this model. Most pronounced was the upregulation of collagen $I V \alpha 1$ and laminin $\gamma 1$, both involved in basement membrane synthesis, assembly and ECM remodeling. Very interesting was the finding of a novel capillary morphogenesis gene, CMG-2, that encodes for a $45 \mathrm{kDa}$ transmembrane protein and that showed binding to collagen type IV and laminin but not to fibronectin and osteopontin [72]. Integrin $\beta 1$, which can dimerize with upregulated integrins $\alpha 1$ and $\alpha 2$, also shows affinity for collagen type IV and laminin [73], stressing again the importance of extracellular matrix remodeling events during capillary formation. Also, a number of signaling pathways involved in capillary formation emerged from the data. JAK/STAT pathway signaling molecules were induced, among which gp 130, leukemia inhibitory factor, janus kinase-1 (JAK-1) and its inhibitor suppressor of cytokine signaling-1 (SOCS-1). Sprouty, a negative regulator of bFGF signaling was upregulated. HUVEC transfected with a mouse sprouty4 showed a decrease in cell migration [74]. Inhibitor of differentiation genes (Id1, Id2 and Id3) were downregulated, as were ephrin $A 1$ and the Eph receptors $B 1$ and $B 4$. This is intriguing since these proteins have been implicated in the promotion of (tumor) angiogenesis [75]. However, they might play a temporal role during the different stages of angiogenesis [76 77$]$. Id proteins are implicated in the control of cell cycle progression and cell differentiation [78]. Heterodimers of basic helix-loop-helix (bHLH) transcription factors normaliy bind E-boxes in the promoters of differentiation genes, and Id proteins prevent transcription of these genes by forming non-functional heterodimers with bHLH proteins. Upregulation of Id 3 can therefore prevent differentiation of EC. Furthermore, Id proteins are upregullated in tumor EC and induce the expression of integrin $\alpha \mathrm{V} \beta 3$ that binds MMP2, required for EC migration, indicating that Id proteins might be involved in the switch from quiescent to angiogenic. EC. Loss of Id1 and Id3 leads to a decreased VEGF production and impaired tumor angiogenesis, suggesting that blocking ld protein protein expression might be an approach to block angiogenesis [78]. Indeed, knockdown of Id3 by RNA interference (RNAi) was able to overcome VEGF induced proliferation, migration and tube formation in HUVEC [79]. Id proteins are also required for neurogenesis [78] and it has recently been appreciated that many genes involved in the development of neuronal tissues are also implicated in angiogenesis, such as the neuropilins, ephrins and roundabout family [80-83]. Other developmental genes, 
among which genes involved in the Jagged/Notch pathway, have also been implicated in particular aspects of angiogenesis, such as adhesion, proliferation and migration [84-86]. The activation of Notch upon ligand binding leads to the transcription of its target genes, including the enhancer of split E(spl) bHLH transcription factors $[80,87]$.

It is interesting to note that neuronal cell adhesion molecule (NRCAM), a protein involved in neuronal development, emerges as upregulated during endothelial tube formation, further extending the analogies observed between neurogenesis and angiogenesis $[88,89]$ : NRCAM acts in concert with integrin $\beta 1$ in mediating neuronal adhesion and neurite outgrowth [90]. NRCAM and integrin $\alpha \mathrm{V}$ were indeed heavilly upregulated in tube forming capillary EC in collagen matrices when compared to proliferating EC in vitro, hence NRCAM is likely to play a role in cell-cell communication and migration during angiogenesis $[88,89]$. Furthermore, NRCAM was extensively expressed in brain but also in placenta, a highly vascularized and angiogenic tissue [88].

In a similar study, HUVEC were cultured in 3D type I collagen gel, in the presence or absence of VEGF [91]. SSH in combination with differential screening identified 31 genes that were upregulated under the influence of VEGF in this culture model, including 4 different MMPs (MMP1, MMP2, MMP3 and MMP9) and the lysosomal cysteine protease cathepsin $B$, all of which are associated with invasion in the collagen gel. In addition, known EC adhesion molecules, including VE-cadherin, vascular cell adhesion molecule-1 (VCAM1) and integrin a2, were upregulated in response to VEGF. Interesting novel candidate genes involved in angiogenesis include epiregulin, a member of the EGF family of mitogens and an activator of COX-2 [92,93], and VCIP, a transmembrane phosphatase with an RGD motif that mediates cell-cell interactions $[94,95]$.

Using GeneCalling ${ }^{\top M}$, Kahn et al. [96] aimed to identify genes upregulated in HUVEC cultured in 3D collagen gels, stimulated with phorbol myristate acetate (PMA), VEGF and bFGF. Genes of different classes were identified, but most prominently upregulated were those associated with extracellular matrix remodeling and adhesion. Of these, integrin $\alpha 2$, collagen IV, MMPs and cathepsin B have already been discussed. This study was later used to identify genes both upregulated in in vitro models of EC differentiation and associated with tumor vasculature by an in silico comparison [36]. In total, 128 genes were identified to be upregulated in in vitro models of angiogenesis as well as in tumor samples compared to normal tissue controls. From these, all genes that showed expression in epithelial tumor cell lines were subtracted yielding a list of 24 genes. The most prominently regulated genes included stanniocalcin-1 and OX40 ligand, previously unrecognized for a role in angiogenesis. Stanniocalcin-1 (STC1) was identified to be upregulated during tube formation of EC $[72,91,96]$ and during stimulation of EC with a combination of HGF and VEGF [70]. STC1 is a secreted glycoprotein whose fish homolog regulates calcium and phosphate uptake and excretion. An angio-inhibitory role of STC1 was demonstrated by the inhibition of migration of EC in response to HGF in the presence of recombinant STC1. 
Furthermore, STC1 expression might act as a stabilizing factor contributing to the maturation of newly formed vessels [97]. OX40 ligand or gp34 is a membrane-bound TNF superfamily member thought to play a role in T-cell costimulatory responses and T-cell interactions with endothelium $[98,99]$. OX40 binding to gp34 leads to the induction of fos and jun expression and the subsequent downstream activation of CCL5/RANTES [100].

A comprehensive overview of gene expression in endothelial tube formation in vitro in different experimental models investigated by means of oligonucleotide arrays has recently been published [89] and discusses relevant genes in light of their functional classiffication. Here, it also emerges that genes related to metabolism, extracellular matrix remodeling and cell surface molecules including adhesion molecules comprise an important group of regulated genes in endothelial tube formation.

A number of genes have been identified (Table 2.2), mainly adhesion molecules (NRCAM, VCAM1, ICAM1), integrins (integrin $\alpha \mathrm{V}$ and $\alpha 2$ ) and matrix remodeling mediators (MMP1, MMP9, laminins $\alpha 4$ and $\gamma^{1}$ ) that show induction in response to different combinations of growth factors in the reported tube formation models. However, when all genes reported in the above described studies $[72,88,89,91,96]$ are subject to functional classification, it appears that cell-cell contact, cell-matrix interactions and matrix turnover related genes represent the larger part of genes regulated in these models of tube formation in three dimensional culture (Figure 2.1B). Furthermore, a clear shift in global gene expression is observed in these models representing the intermediate stages of angiogenesis (Figure 2.1B) when compared to the early stages of angiogenesis (Figure 2.1A).

\section{Gene expression associated with angiogenic EC in vivo}

To date, only a very limited number of studies have attempted to characterize the gene expression profile of tumor EC. The major challenge in doing so is to abtain a sufficiently pure population of cells. The difficulty lies in the fact that only a few percent of the tissue mass consists of EC, and that the EC are embedded in extracellular matrix components and surrounded by pericytes. Ideally, the isolated cells should be used in downstream applications immediately, omitting any subculturing steps or time consuming isolation procedures that can introduce changes in gene expression $[101,102]$. Antibody-based procedures in combination with magnetic bead separation have been used to isolate EC from tissues [101]. In addition high-speed fluorescence activated cell sorting can be applied to isolate EC from tissue sources [102].

The first study published to tackle these technical challenges used SAGE technology to identify markers in EC isolated with magnetic beads [101]. Both a negative selection using antibody-coupled beads directed against epithelial cells, leukocytes, monocytes and macrophages and a positive selection using $\mathrm{P} 1 \mathrm{H} 12$ antibody-coupled beads ensured the selection of a highly pure population of $\mathrm{EC}$ from both colon tumor and normal colon tissue. SAGE tags were categorized as pan- 
Table 2.2: Regulation of common players in in vitro models of 3D collagen tube formation

\begin{tabular}{|c|c|c|c|c|c|}
\hline Function Dessription & Gene : & UniGene ID & Growh factor regulation & & References \\
\hline \multicolumn{6}{|c|}{ Cell cycle regulators and apoptosis related proteins } \\
\hline $\begin{array}{l}\text { BCL2-related protein } \\
\text { A1 }\end{array}$ & $B C L L 2 A 1$ & $H s .227817$ & PMA + GFGF $: M E G F+H G F$ & PRMA+DFGF+VEGF & {$[89,96]$} \\
\hline \multicolumn{6}{|l|}{ Cytosketeton proileins } \\
\hline $\begin{array}{l}\text { Geisolin } \\
\text { Myosin le }\end{array}$ & $\begin{array}{l}\text { GSN } \\
\text { MYOMC }\end{array}$ & $\begin{array}{l}M 8.522373 \\
H s .289226\end{array}$ & $\begin{array}{l}\text { PMA+bFGF +VEGF+HGF } \\
P M A+b F G F+V E G F\end{array}$ & $\begin{array}{l}\text { PMA } \\
\text { PMA }\end{array}$ & $\begin{array}{l}{[72,89]} \\
{[72,96]}\end{array}$ \\
\hline \multicolumn{6}{|c|}{ Extracellular matrix proteins } \\
\hline $\begin{array}{l}\text { A disintegrin and } \\
\text { imstalloprotentiase } \\
\text { domain } 10\end{array}$ & AIDAM10 & $\mathrm{H} \$ .172028$ & $P M A+D F G F+V E G F+H G F$ & $\mathrm{BFGF}+\mathrm{VEGF}$ & {$[88,89]$} \\
\hline Collagan $/ \mathrm{V} 1$ & $\mathrm{COH} 4 \mathrm{AI}$ & Hs. 17441 & PMA+ $+\mathrm{BFGF}$ VEGF & PMA & {$[72,96]$} \\
\hline Cathepsin $B$ & CTSB & Hs.520898 & PMA+DFGF+VEGF & VEGF & {$[91.96]$} \\
\hline Laminin 0 & LAMA4 & $H s .213861$ & PMA +BFGF+VEGF+HGF & PMA & {$[72,89]$} \\
\hline Laminin $y$ & LAMC1 & $\mathrm{Hs.497039}$ & PMA +DFGF+VEGF+HGF & PMA & {$[72,89]$} \\
\hline $\begin{array}{l}\text { Matrix } \\
\text { metalloproteinase } 1\end{array}$ & MMP 1 & $\mathrm{Hs.83} 169$ & PMA+bFGF+VEGF & VEGF & {$[91,96]$} \\
\hline $\begin{array}{l}\text { Matrix } \\
\text { metalloproteinase } 9\end{array}$ & MWP9 & $\mathrm{Hs.297413}$ & $P M A+B F G F+V E G F$ & WEGF & {$[91,96]$} \\
\hline Nidogen 2 & $\mathrm{~N} \| \mathrm{D}_{2}$ & Hs. 369840 & PMA+DFGF+VEGF+HGF & $P M A+B F G F+V E G F$ & {$[89,96]$} \\
\hline $\begin{array}{l}\text { Tissue factor } \\
\text { pathway inhibitor } 2 \\
\end{array}$ & TFPl2 & $H s .438231$ & $\begin{array}{l}\text { PMA+bFGF+VEGF+HGF } \\
\text { PMA }\end{array}$ & $P M A+B F G F+V E G F$ & $\begin{array}{r}{[72,89} \\
96] \\
\end{array}$ \\
\hline \multicolumn{6}{|c|}{ Growth factors, cytokines and hormones } \\
\hline $\begin{array}{l}\text { Placental growth } \\
\text { factor }\end{array}$ & $\mathrm{PGF}$ & Hs.252820 & PMIA + DF GIF + VEEG & PMA & {$[72,96]$} \\
\hline Stanniocalcim 1 & STC1 & Hs. 25590 & PMA $b F G F+V E G F$ & VEGF PMA & {$[72,91,96]$} \\
\hline $\begin{array}{l}\text { Transforming growth } \\
\text { factor } \beta 1\end{array}$ & TGFB1 & Hs. 1103 & $P M A+B F G F+V E G F$ & BFGF+VEGF & {$[88,96]$} \\
\hline \multicolumn{6}{|l|}{ Metabollsm } \\
\hline $\begin{array}{l}\text { HMG-Coenzyme A } \\
\text { reductase }\end{array}$ & HMGCR & Hs. 11899 & PMA+bFGF+VEGF+HGF & PMA & {$[72,89]$} \\
\hline \multicolumn{6}{|c|}{ Protein turnover, modification and transport } \\
\hline $\begin{array}{l}\text { Peptidyglycine: } \\
\text { alpha-amidaling } \\
\text { monooxygenase }\end{array}$ & PAM & Hs.369430 & PNA+bFG|F+VEGF+HGF & PMA+bFGF+VEGF & {$[89,96]$} \\
\hline \multicolumn{6}{|c|}{ Cell surface piroteins, antigens, receptors and adhesion molecules } \\
\hline $\begin{array}{l}\text { Ectonucleaside } \\
\text { triphosphate } \\
\text { diphospholkydrolase } 1\end{array}$ & ENTPD1 & Hs.523173 & PMA+bFGF+VEGF+HGF & PMA & {$[72,89 \rrbracket$} \\
\hline $\begin{array}{l}\text { Chemokine ( } \mathrm{C}-\mathrm{X}-\mathrm{C} \\
\text { motif) recepptor } 4\end{array}$ & CXCR4 & $H s .421986$ & PMA+BFGF+VEGF+HGF & 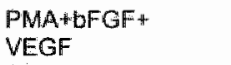 & {$[89.96]$} \\
\hline Dipeptidy peptidase 4 & DPP4 & Hs. 369912 & PMA+bFGF+VEGF+HGF & PNA & {$[72.89]$} \\
\hline $\begin{array}{l}\text { Fms-riglated lyrosine } \\
\text { kinase } 1\end{array}$ & $\mathbb{F} \mathrm{L}$ T1 & $\mathrm{Hs.507621}$ & PMA & VEGF & {$[72,89,91]$} \\
\hline $\begin{array}{l}\text { Intercellutat ad hesion } \\
\text { molectle } 1 \text { (CD54) }\end{array}$ & $\mathrm{CAM} 1$ & $H s .515126$ & PMA+DFGF+VEGF+HGF & PMA & {$[72,89]$} \\
\hline $\begin{array}{l}\text { Interlaukin } 6 \text { signal } \\
\text { transducer }\end{array}$ & ILEST & Hs.532082 & PMA + DFGF+VEGF & PMA & {$[72,96]$} \\
\hline Hntegrio or $(\mathrm{CD} 49 \mathrm{~B})$ & ITGA2 & Hs.482077 & $\begin{array}{l}P M A+b F G F+V E G F+H G F \\
P M A+b F G F+V E G F\end{array}$ & $\begin{array}{l}\text { PMA } \\
\text { VEGF }\end{array}$ & $2,89,91,96 \mathrm{j}$ \\
\hline Integrin aV (CD51) & ITGAV & Hs. 438873 & $\begin{array}{l}\text { PMA+ } \mathrm{DFGF}+\mathrm{VEGF}+\mathrm{HGF} \\
\text { PMA }\end{array}$ & DFGF+VEGF & {$[72,88,89]$} \\
\hline $\begin{array}{l}\text { Neuronal cell } \\
\text { adhesion malecule }\end{array}$ & NRCAM & HSs. 21422 & PMA+ + FGF+VEGF+HGF & DFGF+VEGF & {$[88,89]$} \\
\hline Podocalyxinn-like & PODXL & Hs. 16426 & PMA+BFGF+VEGF & $P M A$ & {$[72,96]$} \\
\hline $\begin{array}{l}\text { Vascullar cell } \\
\text { adhesion molecule } 1\end{array}$ & VCAM1 & Hs. 109225 & PMA+BFGF+VEGF+HGF & VEGF & {$[89,91]$} \\
\hline
\end{tabular}


endotheliall markers when expression was high in normal $E C$, tumor EC and in HUVEC and thuman microvascullar EC (HMVEC). Tumor endothelial markers (TEMs) showed high expression in tumor-derived $E C$ but not in normall EC or in HUVEC, HMVEC, or cell lines. A substantial number of previously uncharacterized genes have been classified as TEMs in this study. This can be partly attributed to the technique used, SAGE, which is not dependent on previously documented or cloned genes. Also, as EC represent only a small fraction of the total cell population in tissues, libraries constructed from these tissues will only reveal endothelial genes that are very highly expressed [101]. Interestingly, TEMs showed a strong bias towards genes functioning in extracellular matrix turnover such as collagens $\|\alpha 1,|\alpha 2, \| l \alpha 1|, V \alpha \mid, V / \alpha 3$ and $X\| l_{\alpha} 1$, and matrix metalloproteinases MMP11 and MMP2, stressing the importance of ECM remodeling during angiogenesis in wivo. When expressed as a percentage of tags, $82 \%$ of the TEMs coded for proteins that function in ECM remodeling and cell migration [101]. Furthermore, many TEMs were involved in adhesion and cytoskeletal remodeling, already discussed to be involved in tube formation. Genes thought to play a role in the initiation of angiogenesis, e.g. nuclear signaling molecules, and genes involved in cell-cycle regulation, metabolism and proliferation were almost completely absent [101].

Very recently, SAGE profiles were published representing malignant brain endothelium and invasive breast carcinoma endothelium [103,104]. Two normal brain EC samples were compared with three glioma-derived EC preparations. The majority of glioma endothelial markers (GEMs) function in extracellular matrix remodeling or are expressed as surface molecules involved in cell-cell interactions and adhesion. Collagens $\mid \alpha 1$, IV $\alpha \|, I V \alpha 2$, and $V / \alpha 1$ were shown to be overexpressed in glioma $E C$, as were a number of MMPs [104]. A similar profile is apparent in breast tumor EC compared to normal breast EC [103]. Combining the information in these three SAGE data sets, it is readily apparent that genes involved in extracellular matrix remodeling and cell-cell or cell-matrix contact represent the majority of upregulated genes during tumor angiogenesis in different types of tumors (Figure 2.1C; Table 2.3).

From the available SAGE data sets, a number of genes can be identified that are overexpressed on the endothelium of different tumors. Colon tumor and glioma EC overexpressed collagens I $\alpha 1, I I / \alpha 1, I V \alpha 1$ and CD164/sialomucin-like [101,104]. Collagen IV 2 2, MMP9, SerpinE, SPARC and an expressed sequence tag (EST) were coordinatelly upregulated in both glioma EC and breast tumor EC when compared to their respective normal counterparts $[103,104]$. Interestingly, almost no overlap in tumor endothelial genes is seen between colon and breast tumors, though the functional classes of upregulated molecules do indicate similarities in gene expression (Table 2.3). Most of these genes are associated with the basement membrane (BM), a speciallized form of extracellular matrix. It has been recognized that BM components such as collagen IV, laminin, nidogen and SPARC are key regulators of angiogenesils. Type IV collagen provides the scaffold for BM assembly and is together with collagens type XV and type XVIII associated with vasculature. EC are generally quiescent when 
bound to the BM suggesting this matrix provides growth arresting cues [105]. During angiogenesis, MMP9 is produced that mobilizes sequestered growth factors and degrades collagen type IV, thereby disrupting $\mathrm{BM}$ organization and exposing cryptic domains of partially degraded collagens. These domains are proangiogenic, and further stimulate EC proliferation [106]. When BM degradation reaches completion, MMP9 resistant collagen fragments remain that are generally anti-angiogenic, such as arrestin and tumstatin. The anti-angiogenic activity of these endogenous inhibitors generated by proteclytic cleavage of collagens is mediated by binding to integrins, mainly type $\beta 1$ [105].

SPARC expression has previously been associated with EC in various tissues $[107,108]$. It is involved in tissue remodeling and proteolytic peptides produced by MMPs in the extracellular matrix can have differential effects on angiogenesis [109]. This interplay between several overexpressed genes in tumor EC may hold promise for the design and application of therapeutic modalities. One major concern that arises from the above described studies is the uncertainty that the genes that were identified are truly markers of tumor angiogenesis rather than physiological angiogenesis. Indeed, most of the TEMs described by St Croix et al. were also expressed during angiogenesis of corpus luteum formation and wound healing [101]. Furthermore, in all published SAGE studies, a relatively small number of samples was used: 2 invasive breast tumor specimen were compared to 1 normal breast sample [103], EC isolated from 1 colon tumor were compared to EC from 1 normal colon [101] and EC from 2 normal temporal lobotomies were compared to 3 grade III or grade IV gliomas [104].

Table 2.3: Tumor endothelial markers in brain, breast and colon identified by SAGE

\begin{tabular}{|c|c|c|c|c|c|}
\hline DDascriptian & Gene & UniGene 10 & Expression & & \\
\hline & & & $\begin{array}{l}\text { Madden } \\
\text { at }[104]\end{array}$ & $\begin{array}{l}\text { Stcroix } \\
\text { ef al. [101] }\end{array}$ & $\begin{array}{l}\text { Parker } \\
\text { et al. }[103]\end{array}$ \\
\hline \multicolumn{6}{|l|}{ Extracollular matrix protelng } \\
\hline $\begin{array}{l}\text { Secreted protein, adidic, } \\
\text { cystelng-rich }\end{array}$ & SPARG & $H 111779$ & Brain & Collon & Breast \\
\hline Collagen lat & COL1A1 & His. 172928 & Brain & Collon & \\
\hline Collagen $\| l l o t$ & COL3AH & $H_{5}: 443625$ & Bralm & Colon & \\
\hline Colfagen Wa 1 & COL4AI & $H s .1744 \|$ & Braärn & Colon & \\
\hline Collagen IVa2 & COL4A2 & $\mathrm{Hs} .508716$ & Brain & & Breast \\
\hline Matrix metalloproteinase 1 & MMPI & $\mathrm{Hs} .83169$ & Drain & Collon & \\
\hline Matrix metalloproteirase 9 & MMPg & $H s .297413$ & Brain & & Breast \\
\hline cD164 antigen, siallomucin & CD164 & Hs. 195727 & Brain & Collon & \\
\hline $\begin{array}{l}\text { Serine (or cysteine) proteinase } \\
\text { inhibitor, clade } \mathbb{E} \text { member } 1\end{array}$ & SERP\|NE & Hs. 414795 & Brain & & Breast \\
\hline \multicolumn{6}{|c|}{ Cell surface proteins, antigens, receplors and adhesion molecules } \\
\hline $\begin{array}{l}\text { Thy-1 cell surface antigen } \\
\text { Plexin domain containing } 1\end{array}$ & $\begin{array}{l}\text { THY1 } \\
\text { PLXDC1 }\end{array}$ & $\begin{array}{l}\text { HS. } 134643 \\
H s .125036\end{array}$ & Bralin & $\begin{array}{l}\text { Colon } \\
\text { Colon }\end{array}$ & Breast \\
\hline \multicolumn{6}{|l|}{ Unkinown } \\
\hline $\begin{array}{l}\text { Homo sapiens clone FLC1492 } \\
\text { PRO312* mRNA }\end{array}$ & EST & & Brain & & Breast \\
\hline
\end{tabular}


The expression of extracellular matrix remodeling related genes and those involved cytoskeleton and cell interactions seems a predominant theme in EC in wivo (Figure 2.1C). The identification of novel genes and genes previously not thought to be involved in angiogenesis by using unblased gene expression profiling techniques will shed new light on the process of angiogenesis and the possible interference therein for therapeutic purposes. Since angiogenesis is not limited to pathological conditions, careful evaluation of putative markers for their tissue specificity is warranted if these are to be used in targeting undesired angiogenesis.

\section{> EC diversity}

\section{Microenvironmental interactions in angiogenesis}

$E C$ in a particular microenvironment interact with various types of cells, such as fibroblasts, pericytes, immune cells, tumor cells or organ cells. In addition, EC can interact with various ECM components and are exposed to different growth factors and cytokines released by its neighbors [110]. As a result, EC lining different vessels exhibit morphological and functional specializations. EC derived from arteries, veins and tissues clearly differed in global gene expression profiles, related to various processes such as ECM remodeling and coagulation cascades [14,71]. A gene expression comparison of cerebral EC (HCEC), part of the blood-brain barrier, with HUVEC revealed that HCEC are characterized by the expression of genes associated with neuroprotection and growth support. Marked differences in growth factor protein release between HCEC and HUVEC in culture were observed that supported the gene expression data [111]. It has been demonstrated that tumor EC isolated from renal cell carcinomas $(R C C)$ retain their persistently activated phenotype in culture. Initially it was shown that RCC tumor EC downregulate adhesion molecules such as ICAM1, ICAM2 and CD34 [112]. Later it was shown that RCC tumor EC were resistant to serumwithdrawal induced apoptosis, a higher proliferation rate and more pronounced tube formation in comparison to HMVEC [113]. Thus, it seems that the original microenvironment programs the endothelial phenotype and that these properties persist (at least to some extent) in both in vitro behavior and gene expression.

\section{Tumor angiogenesis models}

One of the advantages of using cell culture models that mimic an in vivo situation in vitro is the virtually unlimited supply of cells that can be obtained for these purposes. Furthermore, assay conditions can be carefully monitored and can be kept constant ensuring a certain degree of reproducibility. However, in cell culture systems, cells are no longer in their natural environment and might respond aberrantly to certain stimuli, giving a false representation of the in vivo situation [114]. Also, in primary cell cultures such as HUVEC, the culture process itself can induce changes in these cells $[102,115]$. 


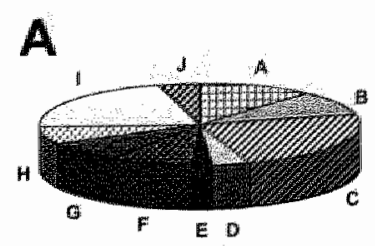

G Signal transduction (A)

Transcription (B)

Apoptosis \& cell cycle (C)

Cytoskeleton (D)

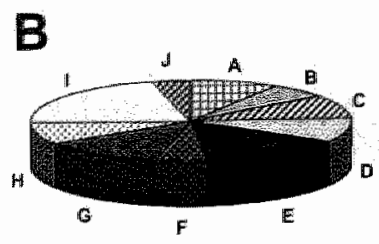

Extracellular matrix (E)

Growth factor/Cytokine (F)

Metabolism (G)

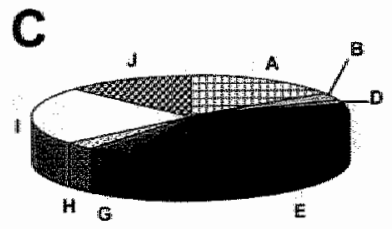

Protein turnover $(\mathrm{H})$

Cell surface and adhesion (I)

8 Unknown (J)

Figure 2.1: Functional classification of annotated genes associated with (tumor-) angiogenesis. A) Genes upregulated by growth factor stimulation of EC in vitro were classified according to their functions ( $N=464)[38,45,49,59,68,70]$. B) Genes associated with capillary tube formation of $E C$ in vitro $(\mathbb{N}=385)[72,88,89,91,96]$. C) Putative tumor endothelial markers overexpressed in EC isolated from tumor tissue and compared to non-tumor $E C(N=69)[101,103,104]$. Gene function was associated with signal transduction (A), transcription (B), cell cycle regulation or apoptosis (C), cytoskeleton (D). extracellular matrix remodeling (E), growth factor, hormone or cytokine action ( $F$ ), metabolism (G). protein turnover, modification and transport (H), cell surface molecules, antigens, receptors and adhesion molecules (I), or unknown function (J).

When regarding angiogenesis in cancer, tumor EC have generally resided in a tumor microenvironment for months to years, whereas culture systems only cover a time period of days. This discrepancy between in vitro and in vivo conditions might translate in an incomplete or hampered mimic of in vivo conditions. Thus, though in vitro approaches might provide useful information in certain settings, the results require cautious interpretation.

Several attempts have been made to overcome these limitations. Co-culture of EC with tumor cells allows studying the interaction between the different cell types. Increased proliferation and network formation of HUVEC was apparent in co-culture with U87 glioma cells. Interestingly, global gene expression profiles of EC in co-culture concordantly shifted towards more genes involved in ECM remodeling and cytoskeletal changes [116]. Depending on the model used, direct interactions, or bidirectional cross-talk over a membrane can be analyzed.

Endothelial precursor cells (EPC), derived from $C D 34+/ A C 133+$ bone marrow progenitor cells were evaluated as a model for tumor EC in comparison to widely used microvascular EC (HMVEC). Only partial overlap $(\sim 30 \%)$ in gene expression patterns of HMVEC and EPC was evident, pointing towards intrinsic differences between these cells. Hence, it was postulated that EPC could be a better model for tumor EC than HMVEC or HUVEC. However, the expression of 565 EPC gene tags overlapped with 
tumor EC, whereas 503 HMVEC gene tags overlapped with tumor EC [117]. suggesting that EPC provide only a marginally better model for tumor EC.

Although apparently similarly regullated, the exact differences, if existing, between angiogenic EC under physiological circumstances and angiogenically activated EC in tumors have not fully been elucidated. Different models have been developed to study angiogenesis in vitro, however, it may be difficult to accurately mimic the temporal and spatial complex actions of all factors exerting effect on EC in vivo. Therefore, extrapolation of data generated by in vitro experiments to the in vivo situation might be limited.

\section{EC heterogeneity and therapeutic interference}

EC diversity observed in tissues, large and small vessells arteries and veins, and tumors constitutes a challenge for the development of therapeutic strategies for the interference with angiogenesis. From the above described SAGE analysis it was apparent that there was only very limited overlap in genes regulated concordantly in breast and colorectal cancer EC, but that both colon tumor EC and breast tumor EC associlated genes were overexpressed in glioma EC. This indicates tumor EC heterogeneity between different tumors and holds implications for the design of future targeted therapies. Also, this heterogeneity may lead to differences in responsiveness to current (anti-angiogenic) therapies. In addition, EC heterogeneity may exist within a tumor [110].

The markedly different global gene expression profiles in growth factor stimulated $E C$, tube forming $E C$ in $3 D$ collagen and EC isolated from tumors (Figure 2.1), stresses the influence of environmental factors on phenotype and gene expression. Therefore, for both the identification of putative therapeutic targets and for the evaluation of novel therapeutics, careful evaluation of the model systems used is warranted.

\section{>> Implications and future directions}

Different studies have attempted to find novel targets for angiogenesis interfering therapies by elucidating gene expression patterns of EC. A number of investigators stimulated $E C$ in culture with different cytokines and growth factors $[38,49,59,68,70]$ whereas others used tube formation models in vitro $[72,88,89,91,96]$. Only very few attempts have been made to profile EC from in wivo sources, mainly due to cumbersome isolation techniques that are required to isolate sufficiently pure populations of EC from tissues [101,103,104]. These different approaches, cell sources and cytokines applied, have led to the identification of different subsets of genes regulated under these circumstances. In general, genes involved in ECM or BM remodeling, e.g. collagen IV 1 , MMP1 and MMP9, showed upregulation in both endothelial tube formation in vitro and in tumor endothelium in vivo. Also, different integrins were identified in the diverse EC sources described here. Some of these 
molecules have been explored for therapeutic interference in cancer. Different inhibitors of MMP activity have been developed for anticancer therapy [118] but they were not very successful in clinical trials [119]. Inhibiting EC adhesion to ECM components by blocking integrin $\alpha V \beta 3$ induces apoptosis in EC and tumor regression [120]. Currently, two oV integrin inhibiting agents, monoclonal antibody Vitaxin and cyclic RGD-like peptide cilengitide, are about to enter the market (www medimmune.com, www merck de). Furthermore, different proteolytic fragments of BM collagens have proven anti-angiogenic activity [121]. Gene expression profiles emerging from the different models described, although not exhaustive, are best viewed in the context of the distribution of the identified genes over a number of functional classes. When the functional classification of the reported genes associated with in witro growth factor and cytokine stimulation of EC growing in monolayers is regarded, it is apparent that cell cycle related genes make up the larger part of regulated genes; followed by genes associated with metabolism (Figure 2.1A). Genes associated with tube formation are those involved in cell-cell and cell-matrix contact, extracellular matrix turnover and signaling (Figure 2.1B). The involvement of extracellular matrix remodeling proteins is even more evident in $E C$ isolated from fresh tissues (Figure 2.1C).

The observation that very few genes overlap in the above mentioned types of studies might reflect the different activation of the used EC sources. Stimuli applied in vitro might be incomplete for a perfect mimic of the tumor microenvironment. It is possible that the concentrations of cytokines and growth factors used are not representative for the in vivo situation. In vitro activation of $E C$ with only one angiogenic growth factor may even overstimulate one pathway and silence others. Likewise, the presence of other specific types of cells such as pericytes, stromal or epithelial cells in vivo influences the phenotype and hence the gene expression profile of the endothelium by a plethora of different signals. Furthermore, one might speculate what the influence of time is; tumor EC have generally been exposed to their tumor environment for months to years whereas most in vitro studies cover onlly a limited period of time. It has been proposed that tumor EC have further progressed into the sequence of angiogenic events whereas cultured EC are at the early stages of angiogenesis. This could explain the gradual increase (from confluent monolayers of cultured cells, via in vitro stimulated tube forming cells to tumor-derived EC) of the proportion of expressed gienes that are associated with extracellular matrix remodeling, a late event in angiogenesis.

Novel genes and genes not previously associated with angiogenesis identified by gene expression profiling studies will provide more insight in the molecular events that direct angiogenesis and may hold clues for the development of novel therapeutic moieties. Tumor endothelium specific markers that are expressed on the cell may be targeted for vessel destruction by, for example, antibodies conjugated to cytotoxic drugs. Gene products that play a crucial role in the active sprouting of capillaries from 
existing vessels are putative candidates for therapeutic interference in the angiagenesis process.

The successes in isolating pure fractions of EC has provided the opportunity to study gene expression in EC from in vivo sources directly, without the introduction of artifacts by culturing steps. Also, bioinformatics approaches to identify novel endothelial markers $[15,36,37,122]$ and to functionally annotate them $[123]$ are promising. Furthermore, public availability of gene expression data in uniform formats provides a tool for surveying gene expression profiles over a large number of experiments, to identify common denominators of centain processes and signaling pathways [124-127]. Taken together, these progresses in understanding angiogenic EC biology, and the concomitant identification of molecules pivotal to this process, might eventually result in the development of novel, potent and specific angiogenesis. modulators for therapeutic purposes. 


\section{> References}

[1] Folkman $\mathrm{d}$. The role of angiogenesis in tumor growth. Semin Cancer Biol 1992;3 (2):65-71.

Folkman $\downarrow$. Tumor angiogenesis; therapeutic implications. N Engl d Med 1971,285 (21):1182-6.

[3] Hanahan D, Folkman J. Patterns and emerging mechenisms of the angiogenic switch during tumorigenesis: Ceil 1996;86 (3):353-64.

(4) Bergers $G$, Benjamin $L E$. Tumerigenesis and the angiogenic switch. Nat Rev Cancer 2003;3 (6):401. 10.

[5] Ferrara $N_{\text {, Houck }} K$, Jakeman $L_{\text {, Leung }}$ DW. Molecular and biological properties of the vascular endothelial growth factor family of proteins. Endocr Rev 1992;13 (1):18-32.

[6] Shing $Y$, Folkman $\downarrow$, Sullivan $\mathrm{R}_{x}$ Butterfield C, Murray ل, Klagsbrun M. Heparin affinity: purification of a tumor-derived capillary endothelial cell growth factor. Science 1984;223 (46-42):1296-9.

[7] Zhang $\mathrm{XN}_{\text {" Su }} Y$, Volpert OV, Vande Woude GF. Hepatocyte growth factoriscatter factor mediates angiogenesis through positive VEGF and negative thrombospondin 1 regulation. Proc Natl Acad Sci U SA 2003; $100(22): 12718-23$.

[8] Davis S, Yancopoulos GD. The angiopoietins: Yin and Yang in angiogenesis. Curr Top Microbiol Immunol 1999;237:173 85 .

[9] Carmeliet P. Mechanisms of angiogenesis and arteriogenesis. Nat Med 2000;6 (4):389-95.

[10] Dvorak HF. Tumors: wounds thall do not heal. Similarities between tumor stroma generation and wound healing. N Engl J Med 1986:315 (26):1650-9.

[11] Folkman J, Ingber D. Inhibition of angiogenesis. Semin Cancer Biol 1992;3 (2):89-96.

[12] Ribatti $D$, Vacca A, Dammacco $F$, English D. Angiogenesis and anti-angiogenesis in hematological malignancies. J Hematother Stem Cell Res 2003:12 (1):11-22.

[13] Perez-Atayde AR, Sallan SE, Tedrow U, Connors $S$, Allred E, Folkman J. Spectrum of tumor angiogenesis in the bone marrow of children with acute lymphoblastic leukemia. Am J Pathol 1997; 150 (3):815-21.

[14] Ho $M$, Yang E, Matcuk $G$, Deng D. Sampas $N$, Tsalenko A, Tabibiazar $R$, Zhang $Y$, Chen M, Talbi $S$, et al. Identification of endothelial cell genes by combined database mining and microarray analysis. Physiol Genomics 2003;13 (3):249-62.

[15] Huminiecki $L_{n}$ Bicknell R. In silico cloning of novel endothelial-specific genes. Genome Res 2000;10 (11):1796-806.

[16] Griffioen AW, Coenen MJ, Damen CA, Hellwig SM, van Weering DH, Vooys W, Blijham GH, Groenewegen G. CD44 is involved in tumor angiogenesis; an activation antigen on human endothelial cells. Blood 1997;90 (3):1150-9.

[17] Hellwig SM, Damen CA, van Adrichem NP, Blijham GH, Groenewegen G, Griffioen AW. Endothelial CD34 is suppressed in human malignancies: role of angiogenic factors. Cancer Lett 1997;120 (2):203 11.

[18] Ruoslahti E. Specialization of tumour vasculature. Nat Rev Cancer 2002;2 (2);83-90.

[19] Ruoslahti $E_{\text {a }}$ Rajotte $D$. An address system in the vasculature of normal tissues and fumors. Annu Rev Immunol 2000; 18:813-27.

[20] Pasqualini R, Ruostahti $E$. Organ targeting in vivo using phage display peptide libraries. Nature $1996 ; 380(6572), 364-6$.

[21] Pasqualini $R$, Koivunen E, Kain $R$, Lahdenranta J, Sakamoto $M$, Stryhn $A$, Ashmun RA, Shapiro LH, Arap $W$, Ruoslanti $E$. Aminopeptidase $N$ is a receptor for tumor-homing peptides and a target for inhibiting angiogenesis. Cancer Res 2000;60 (3):722-7.

[22] Curnis $F$. Arrigoni $G$, Sacchi $A$. Fischetti $L$ " Arap W. Pasqualini R, Corti A. Differential binding of drugs containing the NGR motif to CD13 isoforms in tumor vessells, epithelia, and myeloid cells. Cancer Res 2002:62 (3):867-74.

[23] Chang SS, Reuter VE, Hestom WD, Bander NH, Grauer LS, Gaudin PB. Five different anti-prostatespecific membrane antigen (PSMA) antibodies confirm PSMA expression in tumor-associated neovasculature. Cancer Res 1999:59 (113):3192-8, 
[24] Burrows FJ, Derbyshire EJ, Tazzari PL, Amlot P, Gazdar AF, King SW, Letarte M, Vitetta ES, Thorpe PE. Up-regulation of endoglin on vascular endothelial cells in human solid tumors: implications for diagnosis and therapy. Clin Cancer Res 1995; 1 (12):1623-34.

[25] Castellani $P$, Viale $G$, Dorcaratto $A$, Nicolo $G$, Kaczmarek J. Querze $G$, Zardi $L$, The fibronectin isoform containing the ED-B oncofetal domain: a marker of angiogenesis. Int $\mathrm{J}$ Cancer 1994,59 (5):612-8.

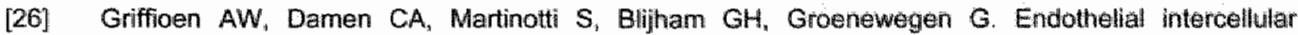
adhesion molecule-1 expression is suppressed in human malignancies: the role of angiogenic factors. Cancer Res 1996;56 (5):1111-17.

[27] Velculescu VE, Zhang L, Vogelstein B, Kinzler KW. Serial analysis of gene expression. Science $1995 ; 270(5235): 484-7$.

[28] Diatchenko L, Lau YF, Campbell AP, Chenchik A, Moqadam F, Huang B, Lukyanov S, Lukyanov K, Gurskaya N, Sverdlow ED, et al. Suppression subtractive hybridization: a method for generating differentially regulated or tissue-specific cDNA probes and libraries. Proc Natl Acad Sci U S A 1996;93 (12):6025-30.

[29] Yang GP, Ross DT, Kuang WW, Brown PO, Weigell RJ. Combining SSH and cDNA microarrays for rapid identification of differentially expressed genes. Nucleic Acids Res 4999:27 (6):1517-23.

[30] Llang P, Pardee AB. Differential display. A general protocol. Mol Biotechnol 1998;10 (3):261-7.

[31] Shimkeis RA, Lowe DG, Tai JT, Sehl P, Jin H, Yang R, Predki PF, Rothberg BE Murtha MT, Roth ME, et al. Gene expression analysis by transcript profiling coupled to a gene database query. Nat Biotechnol 1999;17 (8):798-803.

[32] Schena M, Shalon D, Davis RW, Brown PO. Quantitative monitoring of gene expression patterns with a complementary DNA microarray. Science 1995;270 (5235):467-70.

[33] Lipshutz RJ, Fodor SP, Gingeras TR, Lockhart DJ. High density synthetic oligonucleotide arrays. Nat Genet 1999;21 (1 Suppl):20-4.

[34] Wu TD. Analysing gene expression data from DNA microarrays to identify candidate genes. J Pathol 2001;195 (1):53-65.

[35] Eisen MB, Spellman PT, Brown PO, Botstein D. Cluster analysis and display of genome-wide expression patterns. Proc Natl Acad Sci U S A 1998;95 (25):14863-8.

[36] Gerritsen $M E_{*}$, Soriano $R$, Yang $S$, Ingle $G$, Zlot $C$, Toy $K$, Winer $d_{0}$ Draksharapu $A_{*}$ Peale $F$, Wu TD, ett al. In silico data filtering to identify new angiogenesis targets from a large in vitro gene profiling data set. Physial Genomics 2002;10 (1):13-20.

[37] Gerritsen $M E_{n}$ Peale FV, Jr. Wu T. Gene expression profiling in silico: relative expression of candidate angiogenesis associated genes in renal cell carcinomas. Exp Nephrol 2002;10 (2):114-9.

[38] Wang JL, Liu YH, Lee MC, Nguyen TM, Lee $C$, Kim A, Nguyen M. Identification of tumor anglogenesis-related genes by subtractive hybridization. Microvasc Res 2000:59 (3):394-7.

[39] Bischoff $\Downarrow$, Brasel $C$, Kraling B, Vranovska K. E-selectin is upregulated in proliferating endothelial cells in vitro. Microcirculation 1997;4 (2):279-87.

[40] Tonnesen MG, Jenkins D, Jr., Siegal SL, Lee LA, Huff JC, Clark RA. Expression of fibronectin, laminin, and factor VIll-related antigen during development of the human cutaneous microvasculature. J Invest Dermatol 1985;85 (6):564-8.

[41] Wempe F, Lindner $V$. Augustin HG. Basic fibroblast growth factor (BFGF) regulates the expression of the CC chemokine monocyte chemoattractant protein-1 (MCP-1) in autocrine-activated endothelial cells. Arterioscler Thromb Vaso Biol 1997;17 (11):2471-8.

[42] Miller LJ, Kurtzman SH, Wang $Y$, Andersan KH, Lindquist RR, Kreutzer DL. Expression of interleukin8 receptors on tumor cells and vascular endothelial cells in humen breast cancer tissue. Anticancer Res 1998:18; (1A):77-8:1.

[43] Liu $C$, Shao ZM. Zhang L, Beatty $P$, Sartippour M, Lane T, Livingston $E$. Nguyen M. Human endomucin is an endothelial marker. Biochem Biophys Res Commun 2001:288 (1):129-36.

[44] Kanda H, Tanaka T, Matsumoto $M$, Umemoto E, Ebisuno $Y$, Kinoshita M, Noda M, Kannagi R, Hirata $T$. Murai $T$, el al. Endomucin, a sialomucin expressed in high endothelial venules, supports L-selectinmediated rolling. Int Immunol 2004; 16 (9): 1265-74.

[45] van Beijnum $\Perp R$, Dings RPM, van der Linden $E_{x}$ Zwaans BMM, Ramaekers FCS, Mayo KH, Griffioen AW. Gene expression tumor angiogenesis dissected; specific targeting of tumor endothellum. Submitted. 
(46) Philp D. Huff $T$, Gho YS, Hannappet $E$, Kleinman HK The actin binding ste on thymosin beta4 promotes angiogenesis: Faseb $\mathrm{J} 2003 ; 17(14) 2103-5$.

[47] Malinda $\mathrm{KM}$, Goldstein AL, Keinman HK. Thymosin beta 4 stimulates directional migration of human

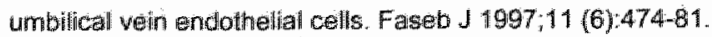

[48] Cha HJ Jeong M, Keinman HK. Role of thymosin beta4 in tumor metastalsis and angiogenesis. $J$ Natl Cancer ingt 2003:95 (22):1674-80.

[49] Zhang $H-T$, Gorn M. Smith $K_{*}$ Graham AP, Lau KKW, Bickinell R. Transcriptional profiling of human microwascular endothelial cells in the proliferative and quiescent state using CDNA arrays. Angiogenesis $1999 ; 3: 211-9$.

[50] Hanai $J$, Dhanabal M, Karumanchi SA, Albanese $C$, Waterman M, Chan $B$, Ramchandran $R$, Pestell $P_{1}$ Sukhatme VP. Endostatin causes $\mathrm{G}$ t arrest of endothelial cells through inhibition of cyclin D1. I Biol chem 2002,277 (19):16464:9.

[51] Hor A. Ikeyama $S$, Sudo K. Suppression of cyclin D1 mRNA expression by the amgiogenesis inhibitor TNP470 (AGM-1470) in vascular endothelial cells. Biochem Biophys Res Commun 1994:204 $(3): 1067-73$

[52] Dormond $O$, Ruegg $C$. Regulation of endothelial cell integrin function and angiogenesis by $C O X-2$, CAMP and Protein Kinase A. Thromb Haemost 2003,90 (4):577-85.

[53] Ruegg C, Mariotti A. Vascular integrins: pleiotropic adhesion and signaling molecules in vascular homeostasils and anglogenesis. Cell Mol Life Sci 2003;60 (6):1135-57.

[54] Ruegg C, Dormond O, Foletti A. Suppression of tumor angiagenesis through the inhibition of integrin function and signaling in endothelial cells: which side to target? Endothelium 2002;9 (3):151-60.

[55] Gutheil JC, Campbell TN, Pierce PR. Watkins JD, Huse WD, Bodkin Du, Cheresh DA. Targeted antilanglogenic therapy for cancer using Vitaxin: a humanized monoclonal antibody to the integrin alphavbeta 3. Clin Cancer Res 2000;6 (8):3056-61.

[56] Chen $N$, Leu SJ, Todorovic $V$, Lam SC, Lau LF. Identification of a novel integrin alphavbeta3 binding site in CCN1 (CYR61) critical for pro-anglogenic activities in vascular endothelial cells. J Biol Chem 2004,279 (42):44166-76.

[57] Brigstock DR. The CCN family: a new stimullus package. J Endocrinol 2003;178 (2):169-75.

[58] Brigstock DR. Regulation of angiogenesis and endothelial cell function by connective tissue growth factor (CTGF) and cysteine rich 61 (CYR61). Angiogenesis 2002;5 (3):153-65.

[59] Abe M, Sato $Y$, cDNA microarray analysis of the gene expression profile of VEGF-activated human umbilical vein endothelial cells. Angiogenesis 2001:4 (4):289-98.

[60] Kuwano T, Nakao S, Yamamoto $H$, Tsuneyoshi M, Yamamoto T, Kuwano M, Ono M. Cyclooxygenase 2 is a key enzyme for inflammatory cytokine-induced angiogenesis. Faseb $\mathrm{J}$ 2004;18 (2):300-10.

[6i1] Dormond $O$, Folletti $A$, Paroz $C$. Ruegg $C$. NSAIDs inhibit alpha $V$ beta 3 integrin-mediated and Cidc42/Rac-dependent endothelial-cell spreading. migration and angiogenesis. Nal Med 2001;7 (9): $1041-7$.

[62] Willams CS, Mann M. DuBois RN. The role of cyclooxygenases in inflammation, cancer, and development. Oncogene 1999;18 (55):7908-16.

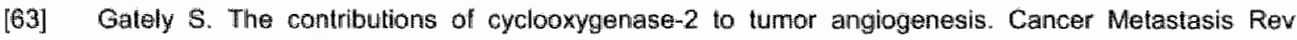
$2000: 19(1-2): 19-27$

[64] Ushiro $S$, Onó $M$. Izumi $H$, Kohno $K$, Taniguchi $\mathbb{N}$. Higastaiyama $S$, Kuwano $M$. Heparin-binding epidermal growth factor-like growth factor: p91 activation induction of plasminogen activatorinhibitor. and tubular morphogenesis in human microvascular endotheliall cells. Jpn J Cancer Res 1996;87 (1):68-77.

[65] Ongusaha PP, Kwak JC. Zwible AJ, Macip S, Higashiyama S, Taniguchi N, Fang L, Lee SW. HB-EGF is a potent inducer of tumor growth and anglogenesis. Cancer Res 2004;64 (15),5283-90.

[66] Haas TL, Stitelman D, Davis SJ. Aple SS, Madri JA. Egr-1 mediates extracellular matrix-driven Iranscription of membrane type 1 matrix metalloproteinase in endothelium. I Biol Chem 1999;274 (32):22679-85.

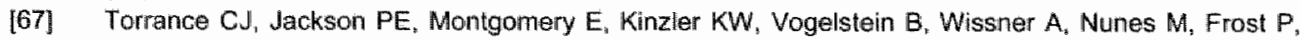
Discafani CM. Combinatorial chemoprevention of intestinal neoplasia. Nat Med 2000:6 (9):1024-8.

[68] Jih YJ, Lien WH, Tsai WC, Yang GW, Li C, WU! LW. Distinct regulation of genes by bFGF and WEGF-A in endothelial cells. Angiogenesis 2001;4 (4),313-21. 


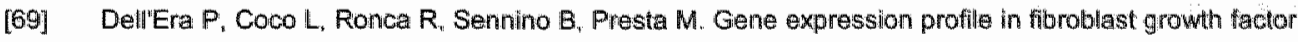
2-transformed endothelial cells. Oncogene 2002;21 (15):24:33-40.

[70] Gerritsen ME, Tomlinson JE, Zlot $C_{6}$ Ziman M. Hwang $S$. Using gene expression profiling to identify the molecular basis of the synergistic actions of hepatocyte growth factor and vasidar endothelial growth factor in human endothelial cells. Br J Pharmacol 2003;140 (4);595-610.

[71] Chi JT, Chang HY, Haraldsen $G$, Jahnsen FL, Trơyanskaya OG, Chang DS, Wang $Z$. Rockson $\mathrm{SG}_{*}$ van de Rijn $M$; Botstein $D$, et al. Endothelial cell diversity revealed by global expression profiling. Proc Natt Acad Sci U SA 2003;100 (19):10623-8.

[72] Bell SE, Mavila A, Salazar $R$, Bayless KJ, Kanagala $S$, Maxwell SA, Davis GE. Differential gene expression during capillary morphogenesis in 3D collagen matrices: regulated expression of genes involved in basement membrane matrix assembly, cell cycle progression, cellular differentiation and G-protein signaling. J Cell Sci 2001:114 (Pt 15):2755-73.

[73] Senger DR, Claffey KP, Benes JE, Perruzzi CA, Sergiou AP, Detmar M. Angiogenesis promoted by vascular endothelial growth factor: regulation through alphalbetal and alpha2betal integrins. Proc Natl Acad Sci U S A 1997;94 (25):13612-7.

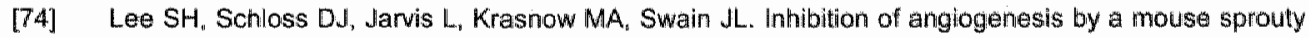
protein. J Biol Chem 2001;276 (6):4128-33.

[75] Sultivan DC, Bicknell R. New molecular pathways in angiogenesis. $\mathrm{Br} J$ Cancer 2003;89 (2):228-31.

[76] Oike $Y$, lto $Y$, Hamada $K_{\text {, }}$ Zhang $X Q$, Miyata $K$, Arai $F$, lnada $T$, Araki $K_{i}$ Nakagata $N$, Takeya $M$, at al. Regulation of vasculogenesis and angiogenesis by EphB/ephrin-B2 signaling between endothellal cells and surrounding mesenchymal cells. Blood 2002;100 (4):1326-33.

[77] Norton JD. ID helix-loop-hellix proteins in cell growth, differentiation and tumorigenesis. J Cell Sci 2000;113 (Pt 22):3897-905.

[78] Lyden $D_{\text {" }}$ Young $A Z$, Zagzag $D$, Yan $W$, Gerald $W$, O'Reilly $R$, Bader BL, Hymes RO, Zhuang $Y$, Manova $K$, et all. Id 1 and $I d 3$ are required for neurogenesis, angiogenesis and vascularization of tumour xenografts. Nature 1999;401 (6754):670-7.

[79] Sakurai $D_{n}$ Tsuchiya $N$, Yamaguchi $A$, Okaji $Y$, Tsuno $N$, Kobata $T$, Takahashi K, Tokunaga $K$. Crucial role of inhibitor of DNA binding/differentiation in the vascular endothellal growth facior-induced activation and angiogenic processes of human endothelial cells. J Immunol 2004;173 (9):5801-9.

[80] Bicknell $\mathrm{R}$, Harris AL. Novel angiogenic signaling pathways and vascular targets. Annu Rev Pharmacol Toxicol 2004;44:219-38.

[81] Parikh AA Fan F. Liu WB, Ahmad SA, Stoeltzing O, Reinmuth $N$, Bielenberg $D$, Bucana $C D$, Klagsbrun $M$, Ellis LM. Neuropilin-1 in human colon cancer: expression, regulation, and role in induction of angiogenesis. Am J Pathol 2004;164 (6):2139-51.

[82] Shima DT, Mailhos C. Vascular developmental biology: getting nervous. Curr Opin Genet Dew 2000;10 (5):536-42.

[83] Suchting $S$, Heal $P$. Tahtis $K_{x}$ Stewart $L M$, Bicknell $R$. Soluble Robo4 receptor inhibits in wivo angiogenesis and endothelial cell migration. Faseb $\mathrm{J} 2005 ; 19$ (1):121-3.

[84] Zimrin AB, Pepper MS, McMahon GA, Nguyen F, Montesamo R, Maciag T. An antisense oligonucleotide to the notch ligand jagged enhances fibroblast growth factor-induced angiogenesis in vitro. J Biol Chem 1996;271 (51):32499-502.

[85] Liu ZJ, Shirakawa T, Li $Y$, Soma A, Oka M. Dotto GP. Fairman RM, Velazquez OC, Herlyn M. Regulation of Notch1 and D\|l4 by vascular endothelial growth factor in arterial endothellial cells: implications for modulating arteriogenesis and angiogenesis. Mol Cell Biol 2003;23 (1):14-25.

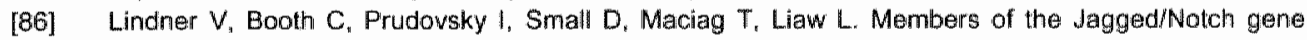
families are expressed in injured arteries and regulate cell phenotype via alterations in cell matrix and cell-cell interaction. Am J Pathol 2001;159 (3);875-83.

[87] Iso T. Hamamori $Y$, Kedes L. Notch signaling in vascular development. Arterioscler Thromb Vasc Biol 2003;23 (4):543-53.

[88] Aitkenthead $M$, Wang $S \mathrm{~J}$. Nakatsu MN. Mestas $\mathrm{J}$, Heard $C$. Hughes CC. Identification of endathelial cell genes expressed in an in vitro model of anglogenesis: induction of ESM-1, (beta)ig-h3, and NrCAM. Microvasc Res 2002;63 (2):159-71.

[89] Gerritsen ME, Soriano R, Yang S, Zlot C, Ingle G. Toy K. Williams PM. Branching out: a molecular fingerprint of endothelial differentiation into tube-like structures generated by affymetrix oligonucleotides arrays. Microcirculation 2:003;10 (1):63-81. 
[90] Treubiert $U$, Brummendorf $T$. Functional cooperation of beta 1-integrins and members of the Ig superfamily in neurite outgrowh induction. 3 Neurosici 1998; 18 (5):1795-805.

191] Wary KK, Thakker GD. Humtsoe JO, Yang J. Analysis of VEGF-responsive Genes Involved in the activation of endothelial cells. Mol Cancer 2003:2 (1):25.

[92] Sasaki $E_{\text {, Pai }} \mathbb{F}_{\text {, Halter }} F_{0}$ Komurasaki $T$, Arakawa T, Kobayashi $K$, Kuroki $T$, Tarnawski AS. Induction of cyclooxygenase-2 in a rat gastric epithellall cell line by epiregulin and basic fibroblast growth factor. J Clin Gastroenterol 1998;27 Suppl 1:S21:7.

[93] Toyoda $H$, Komurasaki $T$, Uchida $D_{*}$ Morimoto $S$. Distribution of mRNA for human epiregulin, a differentially expressed member of the epidermal growth factor family. Biochem $\$ 1997 ; 326$ ( Pt 1):6975 .

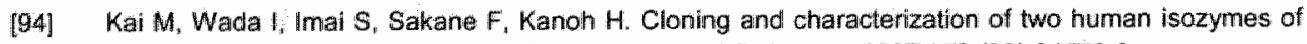
Mg2+aindependent phosphatidic acid phosphatase. J Biol Chem 1997:272 (39):24572-8.

[95] Humtsoe JO, Fong $S_{i}$ Thakker GD, Yang J. Hong J, Wary KK. Regulation off cell-cell interactions by phosphatidic acid phosphatase 2b/NCIP. Embo $J 2003 ; 22(7): 1539-54$.

[96] Kahn J, Mehraban $F$, Ingle G, Xin X, Bryant JE, Vehar G. Schoenfeld J, Grimaldi CJ, Peale $F$, Draksharapu $A$, ot al. Gene expression profiling in an in witro model of angiogenesis. Am J Pathol 2000; $156(6): 1887-900$.

[97] Zlot C, Ingle G, Hongo d, Yang S, Sheng Z, Schwall R, Paoni N, Wang F, Pealle FV, Jr., Gerritsen ME. Stanniocalcin 1 is an autocrine modulator of endothellal angiogenic responses to hepatocyte growth factor. B Biol Chem 2003.

[98] Arch RH, Thampson CB. 4-1BB and Ox40 are members of a tumor necrasis factor (TNF)-nerve growth factor receptor subfamily that bind TNF receptor-associated factors and activate nuclear factor kappaB. Mol Cell Biol 1998:18 (1):558-65.

[99] Imura $A$, Hori $T$, Imada $K$, Ishikawa $T$, Tanaka $Y_{\text {, Maeda }} \mathrm{M}_{2}$ Imamura $S$, Uchiyama $T$. The human OX40/gp34 system directly mediates adhesion of activated $T$ cells to vascular endothelial cells. J Exp Med 1996:183 (5):2185-95.

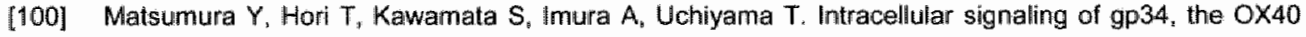
ligand: induction of c-jun and c-fos mRNA expression through gp34 upon binding of its receptor, OX40. لI Immunol 1999; 1633 (6):3007-11.

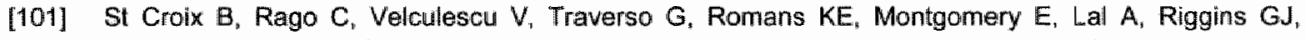
Lengauer $C$, Vogelstein $B$, et al. Genes expressed in human tumor endothelium. Science 2000;289 (5482): $1197-202$.

[102] Favre CJ, Mancuso M, Maas K, McLean JW, Baluk P, McDonald DM. Expression of genes involved in vascular development and angiogenesis in endothelial cells of adutt lung. Am J Physiol Heart Circ Physiol 2003,285 (5): H1917-38.

[103] Parker BS, Argani P, Cook BP. Liangfeng $H_{*}$, Chartrand SD, Zhang M, Saha S, Bardelli A, Jiang $\gamma_{\text {; }}$ St Martin TB, et al. Alterations in vascular gene expression in invasive breast carcinoma. Cancer Res 2004;64 (21):7857-66.

[104] Madden SL, Cook BP, Nacht $M$, Weber WD, Callahan MR, Jiang $Y$, Dufault MR, Zhang $X$, Zhang $W$, Walter Yohrling $J$, et al. Vascular gene expression in nonneoplastic and malignant brain. Am J Pathol 2004;165 (2):601-8.

[105] Kalluri R. Basement membranes: structure, assembly and role in tumour angiogenesis. Nat Rev Cancer 2003;3 (6):422-33.

[106] Xu J, Rodriguez D, Petitclerc E, Kim JJ, Hangai M, Moon YS, Davis GE, Brooks PC. Proteolytic axposure of a cryptic site within collagen lype IV is required for angiogenesis and tumor growth in vivo. J Cell Biol 2001;:154 (5):1069-79.

[107] Porter PL, Sage EH, Lane TF, Funk SE, Gown AM. Distribution of SPARC in normal and neoplastic human tissue. J Histochem Cytochem 1995;43 (B):791-800.

[108] Van Beighum JR, Moerkerk PT, Gerbers AJ, De Bruine AP, Arends JW, Hoogenboom HR, Hufton SE. Target validation for genomics using peptide-specific phage antibodies: a study of five gene products overexpressed in colorectal cancer. Int J Cancer 2002; 101 (2):118-27.

[109] Sage EH, Reed M, Funk SE, Truong: T, Steadele M. Puolakkainen P. Maurice DH, Bassuk ${ }^{A}$. Cleavage of the matricellular protein SPARC by matrix metalloproteinase 3 produces polypeptides that influence angiogenesis. J Biol Chem 2003;278 (39):37849-57. 
[110] Jung YD, Ahmad SA, Liu W, Reinmuth $N$, Parikh A, Stoeltzing O, Fan F, Ellis LM. The rolle of the microenvironment and intercellular cross-talk in tumor angiogenesis. Semin Cancer Biol $2002 ; 12$ (2):105-12.

[111] Kallmann BA, Wagner $S$, Hummel V. Buttmann M, Bayas A, Tonin JC, Rieckmann P. Characteristic gene expression profile of primary human cerebral endothelial cells. Faseb J 2002; 16 \{6):589-91.

[112] Grifficen AW. Phenotype of the tumor vasculature; cell adhesion as a target for tumor therapy. The Cancer Journai 1997;10 (5):249-55.

[113] Bussolati B, Deambrosis I, Russo S, Deregibus MC, Camussi G. Altered angiogenesis and survival in: human tumor-derived endothelial cells. Faseb J 2003:17 (9):1159-61.

[114] Egginton $S$, Gerritsen M. Lumen formation: in vivo versus in vitro observations. Microcirculation 20003:10 (1):45-61.

[115] Aird WC, Glueck SB, Dzau WJ, Pratt RE. Separating the wheat from the chaff: focus on "in sillico data filtering to identify new anglogenesis targets from a large in vitro gene profile data set". Physiol Genomics 2002; $10(1): 1-3$.

[116] Khodarev NN, Y'L J, Labay E, Darga T, Brown CK, Mauceri HJ, Yassari R, Gupta N, Weichselbaum RR. Tumour-endothelium interactions in co-culture: coordinated changes of gene expression profiles and phenotypic properties of endothelial cells. J Cell Soi 2003;116 (Pt 6):1013-22.

[117] Bagley RG, Watter-Yohrling J, Cao $X$, Weber W, Simons $B$, Cook BP, Chartrand SD, Wang $C_{\text {u }}$ Madden SL, Teicher BA. Endothelial precursor cells as a model of turnor endothelium: characterization and comparison with mature endothelial cells. Cancer Res 2003;63 (18):5866-73.

[118] Rudek MA, Venitz J, Figg WD. Matrix metalloproteinase inhibitors: do they have a place in anticancer therapy? Pharmacotherapy 2002;22 (6):705-20.

[119] Overall CM, Lopez-Otin C. Strategies for MMP inhibition in cancer: innovations for the post-trial era. Nat Rev Cancer 2002;2 (9):657-72.

[120] Brooks PC, Montgomery AM, Rosenfeld M, Reisfeld RA, Hu T, Klier G, Cheresh DA. Integrin alpha v beta 3 antaganists promote fumor regression by inducing apoptosis of angiogenic blood vessels. Cell $1994 ; 79(7): 1157-64$.

[121] Sund $M_{n}$ Xie $L$, Kalluri $R$. The contribution of vascullar basement membranes and extracellular matrix to the mechanics of tumor angiogenesis. Apmis 2004;112 (7-8):450-62.

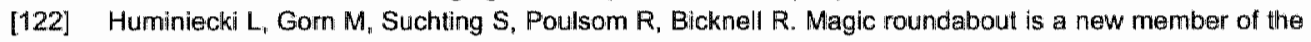
roundabout receptor family that is endothelial specific and expressed at sites of active anglogenesis. Genomics 2002;79 (4):547-52.

[123] Novatchkova $M$, Eisenhaber $F$. Can molecular mechanisms of biological processes be extracted from expression profiles? Case study: endothelial contribution to tumor-induced angiogenesis. Bioessays $2001: 23(12): 1159-75$.

[124] Dudoit S, Gentleman RC, Quackenbush J. Open source software for the analysis of microarray data. Biotechniques 2003; Suppl:45-51.

[125] Brazma A, Hingamp P, Quackenbush J, Sherlock G, Spellinan P, Stoeckert C, Aach J "Ansorge W, Ball CA. Causton $\mathbb{H C}$, et al. Minimum information about a microarray experiment (MIAME)-toward standards for microarray data. Nat Genet 2001;29(4):365-71.

[126] Brazma $A$, Parkinson $H$, Sarkans $U$, Shojatalab $M$, Vilo J, Abeygunawardena $N_{i}$ Holloway $E_{\text {. }}$ Kapushesky M, Kemmeren P. Lara GG, et al. ArrayExpress--a public repository for microarray gene expression data at the EBI. Nucleic Acids Res 2003;31 (1):68-71.

[127] Stoeckert CJ, Jr., Causton HC. Ball CA. Microarray databases: standards and ontologies. Nat Genet $2002 ; 32$ Suppl $469-73$. 


\section{Chapter 3}

\section{Gene expression of tumor angiogenesis dissected; specific targeting of tumor endothelium}

Judy R. van Beijnum, Ruud P.M. Dings, Edith van der Linden, Bernadette M.M. Zwaans, Frans C.S. Ramaekers, Kevin H. Mayo \& Arjan W. Griffioen

Submitted 


\section{$>$ Abstract}

Crucial to designing angiostatic and vascular targeting agents is the identification of target molecules. Since angiogenesis is not limited to pathologies, careful evaluation of putative therapeutic targets is warranted to prevent side effects associated with impaired physiological angiogenesis. To identify tumor-specific angiogenesis markers, we compared transcriptional profiles of angiogenic endothelial cells isolated from both malignant and non-malignant tissues with that of resting endothelial cells. We identified 17 genes that show specific overexpression in tumor endothelium but not in angiogenic endothelium of normal tissues, creating a therapeutic window for tumor vasculature specific targeting. Antibody targeting of four cell-surface expressed or secreted products (vimentin, CD59, HMGB1 and IGFBP7) inhibited angiogenesis in vitro and in vivo. Finally, targeting endothelial vimentin in a mouse tumor model significantly inhibited tumor growth and reduced microvessel density. Our results demonstrate the utility of the identification and subsequent targeting of specific tumor endothelial markers for anticancer therapy. 


\section{> Introduction}

Tumor progression and the development of distant metastases require the presence of an extensive vasculature [1,2]. Active angiogenesis is a hallmark of most malignancies and inhibition of this process is considered to be a promising strategy for the treatment of tumors. In order to develop the most specific and effective antiangiogenic therapies for treating cancer, it is of importance to have a fundamental understanding of the mollecular differences between tumor endothelial cells (EC) and their normal counterparts. Since angiogenesis is not limited to pathological conditions, careful evaluation of the putative targets is warranted to prevent side effects associated with impaired normal physiological angiogenesis. Gene expression profiling techniques are widely used to detect changes in transcript expression levels to study molecular events in biological processes and to identify tissue or tumor endothelium specific markers. Different cell culture models have been developed to study angiogenesis, but the temporal and spatial complex actions of all factors exerting effect on EC in vivo may not be accurately reflected in cultured EC [3]. Gene expression analysis of tumor EC can be problematic because these cells are embedded in complex tissues and comprise only a small fraction of the cells present in a tumor.

To date, only a limited number of studies have characterized the gene expression profile of freshly isolated tumor EC [4-6]. SAGE tag repertoires were generated from EC isolated from both tumor and normal tissues and were compared to identify differentially expressed genes for the discovery of tumor endothelial markers. In these studies, however, gene expression associated with physiological processes was never directly taken into account. In addition, proof of successful targeting of tumor endothelial markers in vivo for cancer therapy has as yet never been provided.

In the present study we used suppression subtractive hybridization (SSH) to compare gene expression profiles of isolated EC from colon carcinoma tissues, nonmalignant angiogenic pllacental tissues, and non-angiogenic normal tissues. We identified 17 tumor angiogenesis genes (TAGs) overexpressed in tumor endothelium as compared to both angiogenic and non-angiogenic endothelium. Four of these genes, encoding surface expressed or secreted proteins, i.e. vimentin, CD59, highmobility group box 1 (HMGB1) and insulin-like growth factor binding protein 7 (IGFBP7), were selected for further investigation. Antibodies targeting these proteins inhibited angiogenesis both in in vitro and in vivo assays. We demonstrate the success of our approach by targeting one of these markers, i.e. vimentin, in a mouse tumor model, resulting in markedly inhibited tumor growth, accompanied with a reduced microvessel density. These results validate the used approach of target finding and suggest the applicability of the identified TAGs. 


\section{> Materials and methods}

Isolation of endothellal cells from fresh tissues

Colorectal carcinoma tissues (Dukes $C_{n} n=5$ ) and distant normal colon tisstes of the same patient $(n=5)$ were obtained directly after surgery Fresh placental tissues $(n=5)$ were obtained from the department of Obstetrics (University Hospital Maastricht). EC were isolated by previously described methods [4], with minor modifications. Tissues were minced with surgical blades and digested for $30^{\prime \prime}$ with $1 \mathrm{mg} / \mathrm{ml}$ collagenase (Life Technologies) and $2.5 \mathrm{U} / \mathrm{ml}$ dispase (Life Technologies) at $37^{\circ} \mathrm{C}$ during continuous agitation. DNAse I (Sigma) was added to a final concentration of 100 $\mu \mathrm{g} / \mathrm{ml}$ and the cell suspension was incubated for another $30^{\prime}$ prior to Ficoll Paque density gradient centrifugation (Amersham Blasciences). EC were immunolabeled with anti-CD31 (clones JC/7OA, DAKO; and EN4, Monosian) and anti-CD34 antibodies (clone Qbend10, Novocastra) and isolated by positive selection using goat anti-mouse lgG coated paramagnetic beads (Dynal). The purity of the isolated EC fraction was assessed by immunofluorescence staining for endothelium specific von Willebrand Factor (rabbit polyclonal antibody, DAKO), and was estimated to be over $97 \%$.

\section{Cell culture}

HUVEC were isolated and cultured as previously described [7] using standard cell culture materials (Greiner Bio-One), HUVEC were activated in RPMll-1640 (Life Technologies) supplemented with $20 \%$ human serum, $10 \%$ filter-sterile conditioned medium of the colorectal tumor cell line LS174T, $10 \%$ filter-sterile conditioned medium of the Caco-2 collorectall tumor cell line, $2 \mathrm{mM}$ L-glutamine (Life Technologies), $50 \mathrm{ng} / \mathrm{ml}$ streptomycin (MP Biomedicals), $50 \mathrm{U} / \mathrm{ml}$ penicillin (MP Biomedicals), $1 \mathrm{ng} / \mathrm{ml}$ bFGF (Reliatech) and $10 \mathrm{ng} / \mathrm{m} \|$ VEGF (Reliatech) until $80 \%$ confluence was reached. Quiescent EC were prepared by culturing in culture medium supplemented with low amounts $(2 \%)$ of serum.

RNA isolation and CDNA synthesis

RNA was isolated using RNeasy Mini reagents (Qiagen) according to the manufacturer's instructions. RNA samples were pooled per 5 EC fractions and SMART $^{\text {TM }}$ CDNA (BD Biosciences) was synthesized from the RNA and amplified for use in SSH.

\section{Suppression subtractive hybridization (SSH)}

SSH was performed with the PCR-Select ${ }^{\mathrm{TM}}$ CDNA subtraction kit (BD Biosciences) according to the manufacturers' instructions. Subtractions were performed to create CDNA repertoires enriched for genes overexpressed in tumor EC (TEC) and for genes differentially expressed in activated and quiescent HUVEC. Subtracted CDNA repertoires were T/A cloned in pCR2.1 (Invitrogen) and introduced in TOP10 cells, 
according to the manufacturers' instructions. Individual colonies were picked and grown overnight at $37^{\circ} \mathrm{C}$ in $2 \times T Y$ bacterial medium (BD Biosciences) supplemented with $10 \mu \mathrm{g} / \mathrm{ml}$ ampicillin (Roche Applied Science).

\section{Differential screening}

Inserts were amplified using the adaptor specific primers Nested 1 and Nested 2R (BD Biosciences) using HotGoldstar Taq polymerase (Eurogentec). PCR products were spotted in duplicate onto nylon membranes (Eurogentec) and hybridized to ${ }^{33} \mathrm{P}$ dCTP (Amersham) labeled cDNA probes derived from colon tumor EC (TEC), normal colon EC (NEC), placenta EC (PLEC), activated and quiescent HUVEC. Membranes were exposed to phosphor screens (Kodak) and images were acquired using the Personal FX phosphorimager (Bio-Rad) at a resolution of $50 \mu \mathrm{m}$ and analyzed as Tiff files using Quantity One software (Bio-Rad). All experiments were performed two times.

Data was processed in MS Excell to identify differentially expressed transcripts. Pair-wise comparisons were performed between duplicate filters hybridized with different probes. Duplicate spots showed excellent concordance $\left(R^{2}>0.99\right.$, data not shown) and were averaged. Average spot intensities were included in the analysis when expression was at least 2.5 times background in any experiment. Spot intensities were normalized for total intensity of the filters under comparison. Gene expression ratios were calculated using the average normalized intensities for each spotted insert cDNA. Hierarchical clustering analysis was performed with Cluster 3.0 [8] and visualized using TreeView (Michael Eisen, University of California at Berkeley, CA).

\section{Sequencing and database searching}

Inserts of selected clones were sequenced using BigDye ${ }^{T M}$ Terminator Cycle Sequencing mix (Applied Biosystems) and analyzed on a 3100 Genetic Analyzer (Applied Blosystems; Genome Center Maastricht). Homology searches were performed using NCBI nucleotide-nucleotide Blast (blastn) algorithm on the combined GenBank/EMBL/DDBJ non-redundant $(\mathrm{nr})$ and expressed sequence tags (EST) databases (http://www.ncbi.nlm.nih.gov/blast) ). Functional annotation of the genes was determined using public GeneOntology databases.

\section{Real-time quantitative PCR}

SYBR green assays were performed using $10 \mathrm{ng}$ cDNA template per reaction, consisting of 1x SYBR Green Master Mix (Applied Biosystems) and $200 \mu \mathrm{M}$ of each primer (Sigma Genosys) (Table 3.1). Reactions were run and analyzed on the ABI7700, performed in triplicate and analyzed using SDS software (Applied Biosystems). All experiments were normalized for cyclophilin A transcript expression to account for variations in template input as previously described [9]. 
Table 3.1: Amplification primers for TAGs

\begin{tabular}{|c|c|c|c|c|c|c|}
\hline TAG & Gane ID & $\begin{array}{l}\text { Accession } \\
\text { No }\end{array}$ & Forward & Reverse: & $5-3^{x}$ & Length \\
\hline TAG 1 & ARPCZ & WM_ 1528629 & GCAMCTGAAGGCTGGAACA & TGAAGAGO & SCGCAACATTAAA & 62 \\
\hline$T A G-3$ & Cofs? & AN_203330 & AGTGGGTGAATGTGGTTATGGCO & CTGGCAC & FGCTCAGGATGTCTTO & 85 \\
\hline $\operatorname{TAG}-4$ & CQKQAP1 & NM_ 0046242 & GCTGOCCATCATTOAABAGCT & TCTCCATO & GCACICTTECTCC & 71 \\
\hline TAS-5 & Col1A 1 & $N H_{1}=00098.2$ & GAGATCGAGATCCGCGC & TGCAGCCA & TTCGACAGTGAC: & 64 \\
\hline TAS-7. & COIAAT & $N M 0016452$ & GQCACCCCATCTOTIGATCAC & GGTAAAG & ATITTGGTOCCAGAA & 94 \\
\hline TAG-2H & HMGB: & MM_002128 & TCTAAGAAGTGCTCAGAGAGGTG & TCATTRC & TCTITCATAACGGG & 104 \\
\hline TAG 23 & EST & $B C O 41913$ & CAAATTCACTAGGCAAGCGGA & GGTGRCO & CIITAATGCAGCTT & 105 \\
\hline TAG. 25 & HEYL & NMOL4457 & TCTGAGCTGCCCCTTCACCAC & ACGTGCC & TTCACATATGAGCCAG & $\Downarrow 22$ \\
\hline TAS-27 & $\mathbb{E} \mathbf{S}$ & NM_017904 & ATTTTGTCCCGAGAAGGTGGC & AGCAGGC & AAGGATTATGGTTCTC & 93 \\
\hline$\pi A G-28$ & HSAPRPR & $x 02160$ & TTCTCAAGGGTGCGAGCTCATC & TCCTCCC $\pi$ & TGGCCACCAATG & 1338 \\
\hline TAQ -29 & IGFEP7 & NM_001553 & AAGGGGTCACTATGGAGTTCAAA & GGCACTCA & ATATTCTCCAGCATCT & 153 \\
\hline TAG 30 & LDHA & NM_O02300 & TGGGCTATTGGATIAAGTGTGGC & TTAACACO & GGGATGAATCCTGG & 76 \\
\hline TAG-31 & PPAP2E & CW337080 & TGGGGAGAATCACATTTGGGTC: & ATGGCTRC & AGAGCTGGTCATGG: & 111 \\
\hline TAC-32 & $\mathrm{PHIC3}$ & A 320446 & TCGCAGATGAATTCAGAGCACAG & TTGATGOG & TGCACAGATCTTCAG & 123 \\
\hline TAG-33 & SPARC & NAM_O0311:B & GCACCACCCGCTITTC & GATCCTTS & TCGATATCCTTCTG & 108 \\
\hline TAG-3Q & $\mathrm{HSPC} 014$ & AFO 077200 & CATTCAGGGTCTATTTGCTCCO & GAAGACGC & ETGAACCTGCTCO & 71 \\
\hline TAG-39 & WM & $\times 56613$ & ACACACICAGTGCAGCAATATAT & GGAGTGTO & GGITGTIAAGAACTA & 152 \\
\hline
\end{tabular}

\section{Immunohistochemistry}

Colon carcinoma and normal colon tissue sections were stained with mouse antihuman CD31 (cllone JC7O/A, DAKO), mouse anti-human vimentin (clone V9. DAKO), mouse anti-human CD59 (clone MEM-43, Chemicon), rabbit anti-human HMGB1 (kind gift of Dr. R.G. Roeder. The Rockefeller University, New York, NY), and rabbit antihuman IGFBP7 (kind gift of Dr. R. Rosenfeld, Oregon Health and Sciences University, Portland, OR). Primary antibodies were diluted in phosphate buffered saline (PBS), $0.5 \%$ bovine serum albumin (BSA) and detected with peroxidase conjugated rabbit anti-mouse IgG (DAKO) or goat anti-rabbit lgG (DAKO). Color was developed using $\mathrm{DAB}$ according to standard protocols.

\section{FACS analysis}

Single cell suspensions of fresh colorectal carcinoma and normal colon tissues were obtained as described above and fixed in $1 \%$ paraformaldehyde. EC were stained with a PE-labelled anti-CD31 antibody (Serotec) and separated from other cells by cell sorting (BD FACSAria; BD Biosciences). CD31 positive cells were subsequently stained using the following antibodies, diluted in PBS, 0.5\% BSA: rabbit anti-vimentin (kind gift of Dr. F.C.S. Ramaekers, Maastricht University, Maastricht, The Netherlands), rabbit anti-IGFBP7 and rabbit anti-HMGB1 followed by biotinylated swine anti-rabbit IgG (DAKO) and streptavidin-FITC (DAKO). 
In vitro sprouting

Sprouting of EC was studied in the tube formation assay. Cytodex 3 beads were overgrown with bovine capillary $E C,(B C E)$ and transferred to a $3 D$ gel, as described previousily [7]. Antibodies dialyzed to PBS were added to the collagen gel and culture medium at the described concentrations. A non-relevant control anti-c-myc antibody was included as control (9E10; Roche). Beads with cells were incubated for 48 hours, after which photographs were taken. Five concentric rings were projected over the photographs, and the number of intersections of rings and sprouting $\mathrm{EC}$ was determined digitally and used as a measure of in vitro tube formation.

\section{Chick chorioallantoic membrane (CAM) assay}

Fertilized white leghorn chicken eggs were used to monitor vessel development in the CAM as described previouslly [7]. Antibodies were dialyzed to $0.9 \% \mathrm{NaCl}$ and administered at the indicated concentrations in a volume of $65 \mu$ for four consecutive days. On day 14, the CAMs were photographed. Quantification of microvessels was performed as described for the sprouting assay.

\section{Mouse tumor model}

Female athymic Swiss nu/nu mice were used and randomly split in four groups. All experiments were approved by the University of Minnesota Research Animal Resources ethical committee. Mice ( $n=6$ per group) were inoculated with $10^{6} \mathrm{LS174T}$ colorectal carcinoma cells in $100 \mu$ RPMI subcutaneously in the right flank. Four days post-inoculation, when established and palpable tumors were present, treatment was started. Mice were treated by i.p. injections every third day with purified RV202 antivimentin antibody (10 mg/kg and $1 \mathrm{mg} / \mathrm{kg}$; MUbio Products), isotype matched IIB5 antiBrdu control antibody ( $10 \mathrm{mg} / \mathrm{kg} ; \mathrm{MUbio}$ ) or saline alone. Tumor volume was determined daily by measuring the diameters of tumors using calipers and calculated as follows: width ${ }^{2} \times$ length $\times 0.52$. Mice were weighed daily to assess possible toxic effects of the treatment. Cryosections $(5 \mu \mathrm{m})$ of excised tumors were stained for CD31 and microvessel density was evaluated as described previously [10]. Antibody targeted to the tissue in vivo was detected using biotinylated secondary goat anti-mouse antibodies (DAKO), and visualized with streptavidin-FITC.

\section{Statistics}

Results are expressed as mean \pm SEM. Comparisons of values in the in witro biloassays were assessed using the Student's t-test. For statistical analysis of the tumor growth curves, two-way ANOVA analysis was performed. 


\section{> Results}

\section{Identification of tumor angiogenesis genes by SSH}

We performed suppression subtractive hybridization (SSH) in combination with CDNA array screening to identify novel tumor specific EC markers in an unbiased manner. We isolated tumor EC (TEC) from a series of colon carcinoma tissues and patient-matched normal EC (NEC) from adjacent normal colon tissues, as well as from placental tissues (PLEC). These isolations were $>97 \%$ pure and therefore perfectly suitable for gene expression analysis as has been demonstrated before [11]. RNA was isolated and used to create subtraction repertoires of genes overexpressed in TEC. In addition, HUVEC were stimulated in vitro with tumor-conditioned medium and used to create additional subtraction repertoires. Subtracted cDNA libraries comprising a total of 2746 cDNA sequences were arrayed and screened for differential expression in TEC, NEC, PLEC and HUVEC. Merely comparing gene expression differences between TEC and NEC may identify genes involved in angiogenesis in general, in addition to genes that represent a "tumor signature" of the EC. To distinguish between these two groups, a comparison with PLEC - representing angiogenic EC - was included. Those genes that are overexpressed in TEC compared to both NEC and PLEC were considered to be tumor angiogenesis specific (Figure 3.1A).

By comparing expression profiles of TEC with NEC, PLEC, and HUVEC, we categorized the TEC overexpressed genes in three different subgroups. Firstly, we identified genes specific for tumor endothelium (tumor angiogenesis genes, TAGs). Forty-one transcripts classified as TAGs (Figure 3.1B, Table 3.2) and showed overexpression in TEC vs. NEC as well as in TEC vs. PLEC. Secondly, 85 transcripts were found to be upregulated in TEC vs. NEC, as well as in PLEC vs. NEC (general angiogenesis genes group $A, G A G / A$, Figure 3.1B, Table 3.2). Thirdly, we identified 24 upregulated transcripts in activated HUVEC vs. quiescent HUVEC, as well as in TEC vs. NEC, which we named GAG/B markers (Figure 3.1B, Table 3.2).

Table 3.2: Characteristics of EC gene expression identified by differential screening of SSH irepertolies

\begin{tabular}{|c|c|c|c|}
\hline \multicolumn{2}{|c|}{ Classification of fumor angiogenesis genes " } & Spiots & Gene IDs \\
\hline TAG & TEC $>$ NEC and TEC $>$ PLEC & 41 & 17 \\
\hline GAG/A & TEC $>$ NEC and PLEC $>$ NEC & 85 & 46 \\
\hline$G A G / B^{\circ}$ & TEC $>$ NEC and HUVEC $+>$ HUVEC- & 24 & 20 \\
\hline
\end{tabular}

\footnotetext{
"Tumor angiogenesis associahed genes

General angiogeinesis gones (in wivo markers)

* General angiogenesis gentes (ion witro and in viwo markmrs

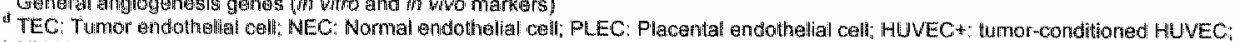
HUVEC-: getescent HUWEC

Whuber of spots thet showed at teast 2 -fold difference in expression in the indicated comparisons

"Number of different genes representing differeratia!ly expressed spots
} 
Sequence analysis revealed that the 41 TAG transcripts represented 17 different genes (Table 3.3). Five of these have previously been identified by SAGE analysis as overexpressed on tumor derived EC, validating our approach [4-6]. The highly abundant collagen l $\alpha 1$ and collagen IV $\alpha 1$ have been reported to be overexpressed on the endothelium of different tumors, including colon carcinoma, breast carcinoma and glioma [4-6], pointing towards the possible existence of pan-tumor endothelium specific transcripts. HEYL is a basic hellix-loop-helix transcription factor that has recently been reported as upregulated in breast tumor vasculature [5]. SPARC and IGFBP7 have been classified as pan-endothelial markers and showed overexpression in EC isolated from colon carcinoma as compared to EC derived from normal colon [4].

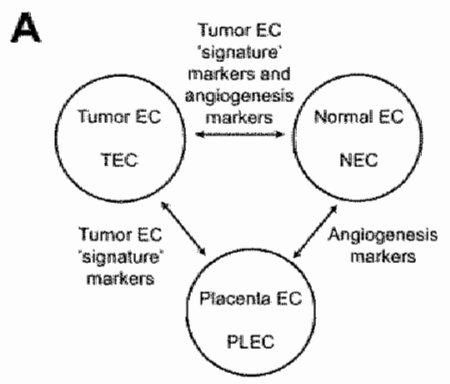

C

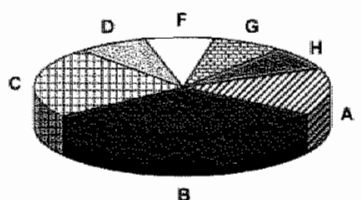

TAG

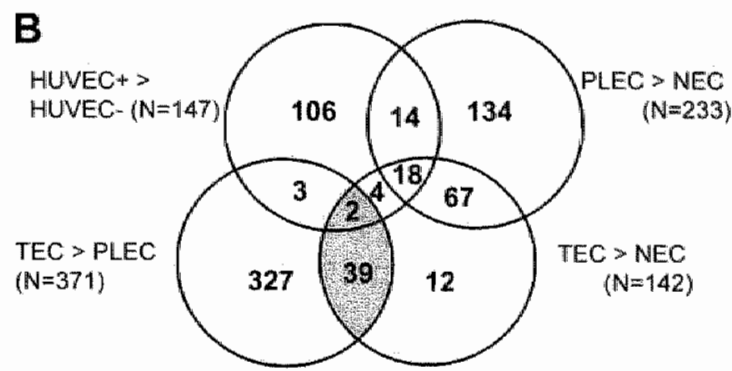

D

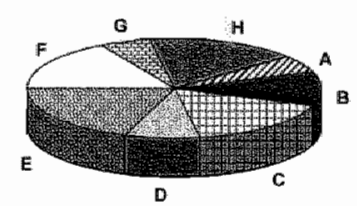

GAG/A
$\mathbf{E}$

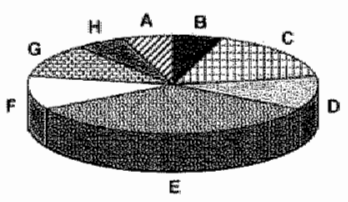

GAG/B
Oy Cytoskeletion (A)
areceptor $(C)$
Protein turnaver $\{$ E
Signallno (O)
Extracellular matrix (B)
Appoptos lis cell cyrole (D)
Motiabolis an (F)
Transeription (H)

Figure 3.1: Endlothelial gene expression analysis.

A) Interrelationship between $\mathbb{E C}$ of different sources and their gene expression signatures. EC from a malignant and pro-angiogenic environment (TEC) are compared with EC from organ matched and patient matched non-malignant sources (NEC), and with non-malignant pro-angiogenic microenvironment (placenta) derived EC (PLEC) to identify the subset of genes that show expression induced by the tumor microenvironment specifically (tumar EC 'signature' markers). B) Venn diagram representation of subtraction repertoire screening. Four pair-wise comparisons were performed by CDNA array screening of SSH repertoires: tumor conditioned (HUVEC+) vs. quiescent HUVEC (HUVEC-), colorectal carcinoma EC vs. normal colon EC (TEC vs. NEC), colorectal cancinoma EC vs. placental EC (TEC vs. PLEC) and placental EC vs, normal colon EC (PLEC vs. NEC). Included are clones that showed at least a 2-fold difference in expression. The shaded area represents the TAGs (overexpressed in TEC vs. NEC and in TEC vS. PLEC). C) TAG markers are strongly biased towards genes associated with extracellular matrix remodeling. D) GAG/A markers (overexpressed in both TEC and PLEC vs. NEC) show a diverse functional profile. E) GAG/B markers (overexpressed in TEC and in activated HUVEC) are biased to protein turnover and transcriptional activity. 
We identified two more TAG transcripts with proposed roles in angiogenesis. PPAP2B has been described as a gene that is upregulated during VEGF-stimulated tube formation of EC in vitro [12]. Very recently, the cytokine HMGB1 was recognized for its role in promoting angiogenesis in vitro [13]. The 10 remaining TAG markers have so far not been reported to functionally contribute to (tumor) angiogenesis, though some are described as being expressed in EC, e.g. vimentin and CD59 [14,15].

\section{Gene expression of tumor EC resembles the profile of physiological angiogenesis}

Further gene expression analysis revealed that the majority of TEC overexpressed transcripts $[(18+67) / 142 \approx 60 \%]$ are also associated with angiogenesis under physiological conditions in vivo, and are therefore not specific for tumor angiogenesis (Figure 3.1B). These $85 \mathrm{GAG} / \mathrm{A}$ transcripts represent 46 different genes (Table 3.4), including genes that have been associated with angiogenesis such as MMPs [16], integrin $\beta 1[17]$ and endothelial cell specific molecule-1 [18].

Table 3.3: Tumor angiogenesis genes (TAGs)

\begin{tabular}{|c|c|c|c|c|c|c|c|}
\hline $\mathrm{TAG}^{\mathrm{a}}$ & Gene $1 D^{b}$ & & Anccession $\mathrm{No}^{\mathrm{C}}$ & Function & $\begin{array}{l}\text { No of } \\
\text { spots }\end{array}$ & $\begin{array}{l}\text { Library oris } \\
\text { HUNEC }\end{array}$ & $\begin{array}{l}\text { igin } \\
\text { TEC }\end{array}$ \\
\hline \multicolumn{8}{|c|}{ Genes prevlously associated with anglogenesis } \\
\hline TAG-5 & Collagen $|\alpha|$ & ColtA1 & NM_000088.2 & Extracellular matrix & 4 & & $x$ \\
\hline TAG-7 & Collagen $|\mathrm{W} \alpha|$ & Col4A1 & NM_001845.2 & Extracellular matrix & 16 & $x$ & $x$ \\
\hline TAG-2H & High mobility group box -1 & HMGB1 & $\mathrm{NM}_{\operatorname{moz}} 002128.3$ & Extracelular matrix & 1 & & $x$ \\
\hline TAG-25 & $\begin{array}{l}\text { Hairy/enhancer of split } \\
\text { with YRPW motif }\end{array}$ & $H E Y L$ & NM_014571 & Transcription & 1 & & $x$ \\
\hline $\mathrm{TAG}-29$ & $\begin{array}{l}\text { Insulin- jike growth factor } \\
\text { binding protein } 7\end{array}$ & IGFBP7 & $\mathbb{N M} 001553$ & Extracellular matrix & 1 & $x$ & \\
\hline TAG-31 & $\begin{array}{l}\text { Phosphatidic acid } \\
\text { phosphatase type } 2 B\end{array}$ & PPAP2B & CV337080 & $\begin{array}{l}\text { Metabolism, } \\
\text { coll maintenance }\end{array}$ & 1 & & $x$ \\
\hline TAG-33 & $\begin{array}{l}\text { Secretad protein acidic, } \\
\text { rich in cysteine }\end{array}$ & SPARC & $\mathrm{MM} 003118.1$ & Extracellular matrix & 5 & & $x$ \\
\hline \multicolumn{8}{|c|}{ Genes with no prewlous association to anglogenesis } \\
\hline TAG-1 & Actin related protein $2 / 3$ & ARPC2 & NM_152862.1 & Cyloskeleton & 2 & & $x$ \\
\hline TAG 3 & CD59 antigen $\mathrm{p} 1 \mathrm{~B}-20$ & CD59 & NM_000611 & Cell surface & 1 & & $x$ \\
\hline $\mathrm{TAG}_{4}$ & COK2-associated protein 1 & CDK2AP1 & $N M \_004642.2$ & $\begin{array}{l}\text { Apoptosis, } \\
\text { Cenl cycle }\end{array}$ & 1 & & $x$ \\
\hline TAG-23 & IMAGE 5299642 & EST & $\mathrm{BC} 041913$ & Unknown & 1 & $x$ & \\
\hline TAQ-27 & IMAGE 4332004 & $\mathbb{E S T}$ & NM_017994.1 & Unkinown & 1 & & $x$ \\
\hline TAG-28 & Insulin receptor precursor & HSIRPR & $\times 02160$ & Cell surface & 1 & & $x$ \\
\hline TAG. 30 & Lactate dehydrogenase $\mathrm{B}$ & LDHB & NM_002300 & $\begin{array}{l}\text { Metabolism, } \\
\text { cell maintenance }\end{array}$ & 1 & $x$ & \\
\hline $\mathrm{TAG}-32$ & Pollyhomeotic like 3 & $\mathrm{PHC3}$ & A.J 320486 & Unkinown & 1 & & $x$ \\
\hline TAG-38 & $\begin{array}{l}\text { Voltage gated } K \text { channel } 3 \\
\text { subunit } 4.1\end{array}$ & HSPC014 & AF 077200 & Unknown & 1 & $x$ & \\
\hline $\mathrm{TAG}-39$ & Vimentin & VIM & $\times 56134$ & Cytoskeleton & 3 & $x$ & $x$ \\
\hline
\end{tabular}


In vitro endothelial cell activation has limited value for studying tumor angiogenesis

From our gene expression analysis, it is obvious that only a limited number of genes upregulated in TEC vs. NEC overlapped with genes overexpressed in tumorconditioned HUVEC in vitro (GAG/B; Figure 3.1B. Table 3.4). Most of the GAG/B markers overlap with genes associated with physiological angiogenesis (GAG/A; Figure 3.1B, Table 3.4). In addition, hierarchical clustering analysis suggests that the overall expression pattern in the HUVEC model relates most to that emerging from physiological angiogenesis (i.e. the comparison between PLEC and NEC; Figure 3.2).

\section{TAG markers are functionally classified as associated with late events of angiogenesis}

We assigned a functional annotation to every gene, and analyzed the distribution of genes within different functional classes. TAG markers are predominantly biased towards genes associated with cytoskeletal and extracellular matrix remodeling. indicative of late events in the process of tumor angiogenesis. Genes associated with protein turnover and transcription, indicative of early events in the angiogenesis cascade, are underrepresented within TAG (Figure 3.1C). In contrast, the latter genes are present in the GAG/A class (Figure 3.1D). Similarly, GAG/B molecules are mainly involved in these early stages in the angiogenesis process (Figure 3.1E).
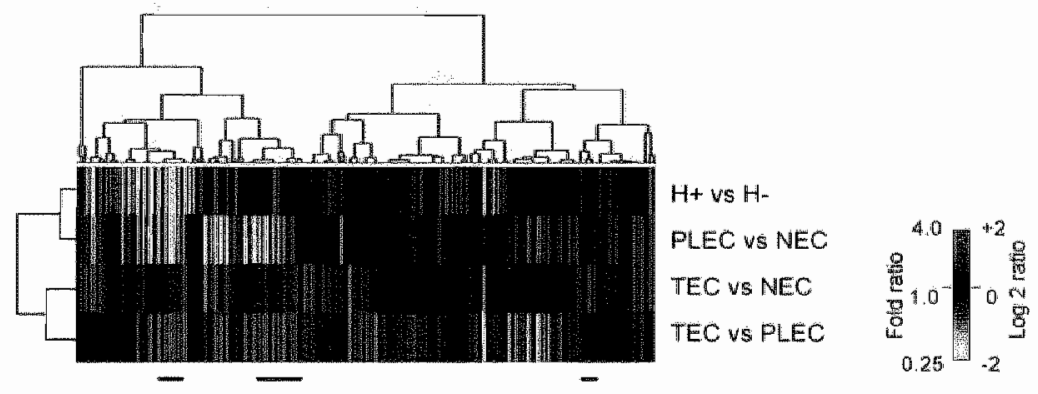

Figure 3.2: Hierarchical clustering of differential gene expression patterns in TEC, NEC, PLEC and HUVEC.

Hierarchical clustering analysis of expression ratios of the entire SSH repertoire. The dendrogram visualizes the results of hierarchical clustering analysis based on similarities in gene expression patterns of the different comparisons indicated to the right of the clustered image maps. Expression ratios are color-coded as indicated on the far right and shown for the indicated comparisons. Bars at the bottom indicate clustered regions containing the genes that confer a tumor 'signature' to EC (TAGs). The dendrogram at the left is an indicator of overall correlation between the comparisons shown in the rows. Note that the differential gene expression during physiological angiogenesis (PLEC vs. NEC) is most closely related to the differential gene expression in activated vs. quiescent HUVEC $(\mathrm{H}+$ vs. $\mathrm{H}-)$. 
Table 3.4: General angiogenesis genes (GAG/A and GAG/B)

\begin{tabular}{|c|c|c|c|c|c|c|c|}
\hline Gene $\mathbb{D D}^{3}$ & & $\begin{array}{l}\text { Accession } \\
\text { Mo }\end{array}$ & Class $^{C}$ & Funnction $^{\sigma}$ & $\begin{array}{l}\text { No of } \\
\text { spoitsit }\end{array}$ & $\begin{array}{l}\text { Library o } \\
\text { HUVEC }\end{array}$ & $\begin{array}{l}\text { rigin } \\
\text { TEC }\end{array}$ \\
\hline $\begin{array}{l}\text { A kinase (PRKA) anctior protein } \\
13 \text { (AKAP } 13 \text { ) }\end{array}$ & AKAP13 & Nilu 007200 & $A$ & Signating & 1 & $x$ & \\
\hline Cathepsin $B$ & $\operatorname{crse}$ & NHA_ $147783:-1$ & $A$ & Extracellular matrix & 11 & & $x$ \\
\hline Caveoulin 1 , caveolae protein & CAVI & Whit 004753 & A & Receptor & 2 & $x$ & \\
\hline CD86 antigen & $\operatorname{coses}$ & AlM 175882 & A & Surface artigen & 1 & & $\mathrm{x}$ \\
\hline QONA FLUNZ199 & EST & AK05676\% & A. & Unknown & 1 & $x$ & \\
\hline Chemokine $(\mathrm{C}-\mathrm{C}$ motin) ligand 2 & Colz & NAM_002982 & A & Signaling & 1 & $x$ & \\
\hline dCMP deaminase & DCTD & Mat_on1924.1 & A & $\begin{array}{l}\text { Meltabolism, } \\
\text { cell maintenance }\end{array}$ & 1 & & $x$ \\
\hline Defender aganst cell death 1 & DADI & No_A_001344: & A & $\begin{array}{l}\text { Apaptosis, Cell } \\
\text { cycle }\end{array}$ & 1 & $x$ & \\
\hline EST10870 HUVEC & EST & AA296386 & A & Unknown & 2 & $x$ & \\
\hline $\begin{array}{l}\text { Eukaryotic translation initiation } \\
\text { fector } 4 A \text {, isoform } 1\end{array}$ & EIFAAT & NMLOD1416i & A & Protein tumover & 1 & $x$ & \\
\hline FK506 bindting protein $1 \mathrm{~A}$ & FKEP 1A & NM 000801 & A & Signalíng & 1 & $x$ & \\
\hline FLل 37490 & EST & AKOgABOS.1 & $A_{1}$ & Unknown & 2 & & $\times$ \\
\hline Heme binding protein 1 & HEBPI & NM_015987.2 & $A_{1}$ & $\begin{array}{l}\text { Metabolism, } \\
\text { cell maintenance }\end{array}$ & 1 & & $x$ \\
\hline Hypothetical protein MGC 7036 & MGC7036 & NAM 145058 & A & Unknown & 1 & & $x$ \\
\hline MAGE 2028956 & EST & A.1793192 & $\mathbf{A}$ & Unknown & 1 & $x$ & \\
\hline MAGE 2096486 & EST & A/422919 & A & Unknown & 1 & & $x$ \\
\hline MAGE 28:6112 & EST & AN 269923 & A & Unknown & 1 & $x$ & \\
\hline integrin beta 1 & ITGB1 & NM_002211 & A & Receptor & 1 & $x$ & \\
\hline $\begin{array}{l}\text { Isoprenylcysteine carboxyl } \\
\text { methyltransferase }\end{array}$ & $\mathrm{CANT}$ & NM_ 1701705.1 & A & $\begin{array}{l}\text { Metabolism, } \\
\text { cell maintenance }\end{array}$ & 1 & & $x$ \\
\hline Lung cancer oncogene 5 & HLCS & AY 1176900.1 & A & Unknown & 1 & $x$ & \\
\hline $\begin{array}{l}\text { Major histocompatibility } \\
\text { complex, class II, DR alpha }\end{array}$ & HLA-DFA & $\mathrm{BC} 032350$ & A & Surface antigen & 24 & & $x$ \\
\hline $\begin{array}{l}\text { Matrix metalloproteinase } 1 . \\
\text { intersititial collagenase }\end{array}$ & MMP1 & $N M_{-} 002421$ & A & Extracelliular matrix & H & $x$ & \\
\hline $\begin{array}{l}\text { Matrix metalloproteinase } 3 \text {, } \\
\text { stromelysin } 1\end{array}$ & MMP3 & $N M_{-} 002422$ & A & Extracellular matrix & 1 & & $x$ \\
\hline $\begin{array}{l}\text { Pitulary tumor-transforming } 1 \\
\text { interacting protein }\end{array}$ & PTTGIP & NM_004339.2. & A & Signaling & 1 & & $x$ \\
\hline Rød51 ตสcociated protein & RADS1API & NilM 006479 & A & $\begin{array}{l}\text { Melabolism, } \\
\text { cell maintenence }\end{array}$ & 1 & $x$ & \\
\hline Filjogomal proteir L22 & $\mathrm{RPL} 22$ & Nit___000983 & A & Protein turnover & 9 & $x$ & \\
\hline Tubulin, atphe 3 & TUBA3 & $\operatorname{Bcos0637}$ & A & Cytoskeletor & 4 & $x$ & \\
\hline $\begin{array}{l}\text { Writ simian leukemia wiral } \\
\text { oncogene homolog } \mathrm{B}\end{array}$ & RALE & Bco18163 & A & Signaling & 1 & & $x$ \\
\hline Androgene induced 1 & AIG-1 & $\mathrm{BCO} 25278$ & $A, B$ & Unknown & 1 & $x$ & \\
\hline $\begin{array}{l}\text { Atp synthase tht transporting } \\
\text { complex subunit } c\end{array}$ & ATPSG1 & NM__oot:575 & $A, B$ & $\begin{array}{l}\text { Metabolism, } \\
\text { cell maintenance }\end{array}$ & 1 & $x$ & \\
\hline Diazepam binding inhibitor & DBI & $M+5087$ & $A, B$ & Signaling & 1 & $x$ & \\
\hline $\begin{array}{l}\text { Ectonucleoside triphosphate } \\
\text { diphospholnydrolase } 1\end{array}$ & ENTPO4 & $\mathrm{BCO} 77664$ & $A B$ & Receptor & $\|$ & & $x$ \\
\hline $\begin{array}{l}\text { Endothellal cell-specific } \\
\text { molecule } 1\end{array}$ & ESM1 & NM_oo7036 & $A B$ & Receptor & $\pi$ & $x$ & \\
\hline $\begin{array}{l}\text { Eukaryotic translation elongation } \\
\text { factor } 1 \text { psilon } 1\end{array}$ & EEFIEA & NM_OOA280.2 & $A, B$ & Protein turnaver & 2 & * & \\
\hline $\begin{array}{l}\text { Hesterogeneous nuclear } \\
\text { ribonucleoprotein } \mathrm{C} \text { C } / / C 2)\end{array}$ & HNRPC & $\mathrm{BC} 003394$ & $A, B$ & Protein turnover & 1 & $x$ & \\
\hline HSPgo alphe & HSPCA & NM_ 005348 & $A, B$ & $\begin{array}{l}\text { Metabolism, } \\
\text { cell maintenance }\end{array}$ & 1 & $x$ & \\
\hline IMAGE 757234 & EST & $18 \times 115183$ & $A, B$ & Unikmown & 1 & $x$ & \\
\hline $\begin{array}{l}\text { WMAGE } 4182080, \text { CARDB } \\
\text { homologue }\end{array}$ & CARDB & $B C 046136$ & A. B & $\begin{array}{l}\text { Apoptosis, } \\
\text { Cell cycle }\end{array}$ & 1 & $x$ & \\
\hline
\end{tabular}




\begin{tabular}{|c|c|c|c|c|c|c|c|}
\hline $\begin{array}{l}\text { KLAA0349, FLJ33555, Ub:1 } \\
\text { homologue }\end{array}$ & KUA40349 & ABOOL347 & A, 8 & Protein tumover: & 1 & & $x$ \\
\hline $\begin{array}{l}\text { Matrix metalloproteinase } 10, \\
\text { stromelysin } 2\end{array}$ & MMP10 & NM_ 002425 & $\mathrm{AB}$ & Extracellutar matrix & 2 & $x$ & \\
\hline $\begin{array}{l}\text { Mitochoindrial ribosomall protein } \\
\$ 27\end{array}$ & MRPS27 & $8 \mathrm{CO} 011818$ & $A_{B} B$ & Protein turnover & 1 & $x$ & \\
\hline $\begin{array}{l}\text { Split hand/foot malformation } \\
\text { (ectrodactyly) type } 1\end{array}$ & SHFM1 & NM_-106304 & $\mathbb{A}, \mathrm{B}$ & $\begin{array}{l}\text { Apoptosis. } \\
\text { Cell cyole }\end{array}$ & 1 & $x$ & \\
\hline $\begin{array}{l}\text { SRY (sex-determining reglon } Y \text { ) } \\
\operatorname{box} 4\end{array}$ & $\sin \times 4$ & NM_@03107 & $A, B$ & Transcription & 2 & $x$ & \\
\hline Thymosin, betta $4, X$-linked & TMSBAX & NM_ 021109 & $A, B$ & Cytoskeleton & 1 & $x$ & \\
\hline $\begin{array}{l}\text { Ubiquitin conjugating enzyme } \\
\text { E2L3 }\end{array}$ & UBE2L3 & NM_00334.7 & $A, B$ & Protein turnower & 1 & $x$ & \\
\hline $\begin{array}{l}\text { Zinc finger motif enthancer } \\
\text { binding protein } 2\end{array}$ & ZNFG44 & NM_ 032186 & $A, B$ & Transcription & 1 & $x$ & \\
\hline $\begin{array}{l}\text { Platelet/endothelial cell } \\
\text { adhesion molecule } 1\end{array}$ & PECAM1 & MM_.00044.2.2 & $B$ & Surface antigen & 1 & $x$ & \\
\hline Ribosomal protein L21 & RPL21 & 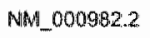 & $\mathrm{B}$ & Protein turnower & 2 & $x$ & \\
\hline
\end{tabular}

\section{Validation of TAGs}

Overexpression of the 17 TAGs was confirmed using real-time quantitative PCR as a second independent validation technique. For 16 different genes (94\%) overexpression in TEC vs. NEC was confirmed, also for 16 genes (94\%) overexpression in TEC vs. PLEC was confirmed (Figure 3.3A). Taken together, 15 out of $17(88 \%)$ genes were validated by RTQ-PCR to be TAG markers.

For subsequent studies of TAG markers at the protein level, we selected 4 different membrane associated or secreted molecules that may be feasible drug targets: (i) CD59 (TAG-3), a GPI membrane-anchored inhibitor of complement activation [19]; (ii) HMGB1 (TAG-21), a secreted cytokine as well as a non-histone DNA binding protein [20,21]; (iii) insulin-like growth factor binding protein 7 (IGFBP7. TAG-29), a secreted molecule with growth factor modulating function [22]; and (iv) vimentin (TAG-39), an intermediate filament protein that was recently demonstrated in macrophages to be actively secreted [23]. Immunohistochemical analysis in colorectal carcinoma and normal colon epithelium indicated that all four proteins were overexpressed on the tumor vasculature. While vimentin, IGFBP7 and CD59 were predominantly expressed in the endothelial compartment, HMGB1 was found to be expressed in stromal and epithelial cells as well (Figure 3.3B). Vimentin expression was detected in EC of both tumor and normal colon tissue, though heavily overexpressed on tumor endothelium. IGFBP7 expression in normal colon tissue was hardly detected, whereas tumor blood vessels showed abundant expression of IGFBP7. CD59 expression was mainly localized to vasculature, in particular to the luminal cell membrane (Figure 3.3B). This is in line with its reported expression as membrane protein with a role in protecting EC from complement-mediated lysis by binding complement proteins $\mathrm{C} 8$ and $\mathrm{C} 9$ to prevent the formation of the membrane attack complex [19]. HMGB1 staining was detected in EC, as cytoplasmic protein, but 
also in epithelial cells, where the localization was predominantly nuclear. In addition, diffuse stromall staining was observed. Protein expression was much more abundant in colorectal tumor tissue compared to normal colon tissue, predominantly in the stromal compartment, consistent with a secretion product (Figure 3.3B) [24].

Since immunohistochemistry is a qualitative rather than a quantitative technique, we set out to determine the expression of these TAGs on freshly isolated EC of tumor and normal tissues by flowcytometry. We were able to quantitatively confirm the overexpression of vimentin, IGFBP7 and HMGB1 protein on colon tumor endothelium compared to normal colon endothelium (Figure $3.3 \mathrm{C}$ ). Antibody species cross-reactivity prevented CD59 protein detection on freshly isolated EC by this method. The expression of CD31 did not differ between TEC and NEC (Figure 3.3C). These observations further support the value of these TAG proteins as tumor EC markers.
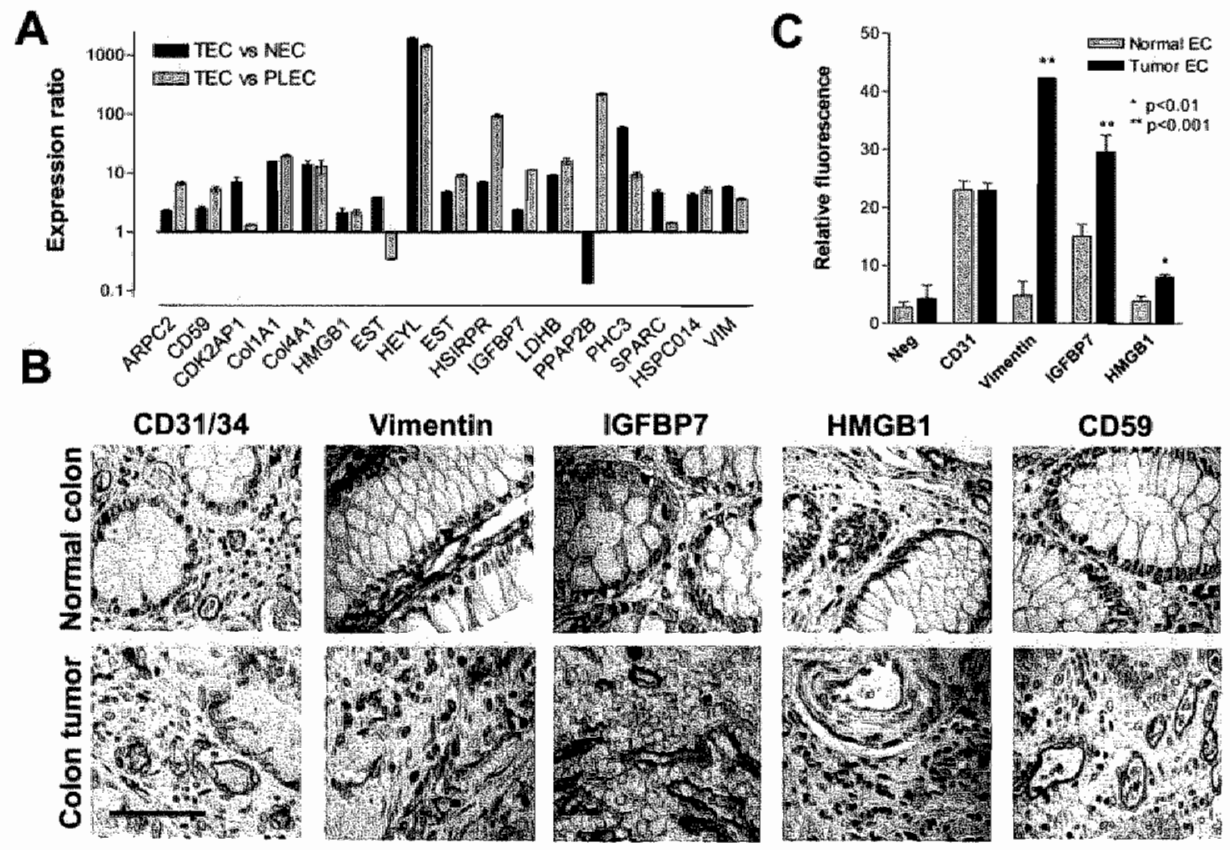

Figure 3.3: Expression vallidation of TAGs.

A) Transcriptional validation of TAG markers by quantitative real-time PCR. Expression ratios (meantSEM) in TEC vs. NEC (black bars) and TEC vs. PLEC (grey bars) normalized fior cyclophillin A are shown. B) Immumohistochemilcal staining of CD31/CD34 and different TAGs in colorectal tumor and normal colon tissue sections. Scale ber represents $50 \mathrm{wm}$. C) Protein expression levels (mean fluorescence intensity, \pm SEM) of HMGB1, IGFBP7 and vimentin on tumor $\mathrm{EC}$ as compared to normal EC, assessed by flow cytometry. 
Interference with TAG proteins inhibits angiogenesis in vitro and in vivo

To investigate whether the overexpression of the selected TAG markers is causally related to the process of angiogenesis, in vitro bioassays were performed. Antibodies directed against CD59, HMGB1, IGFBP7 and vimentin were tested for their effect on endothelial tube formation in an in vitro collagen gel based sprout formation assay. Antibodies directed against the latter three showed significant inhibitory effects on sprout formation in vitro whereas antibodies directed against CD59 had a limited effect. The control antibody did not show any effect (Figure 3.4A). These observations suggest that the targeted proteins are actively involved in the process of capillary tube formation in vitro.

To investigate whether these TAGs are involved in anglogenesis in vivo, the antibodies were tested in the chorioallantoic membrane (CAM) of the chick embryo. All four antibodies were checked for reactivity with CAM endothelium by immunohistochemistry. Three of the antibodies (directed against CD59, HMGBI and vimentin) positively stained CAM blood vessels and were therefore usable in the CAM assay (data not shown). Similar to the sprout formation assay, antibodiles against

A
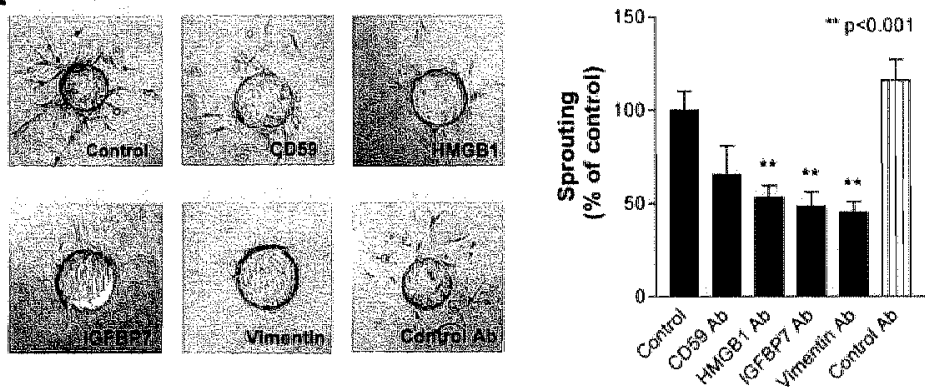

B
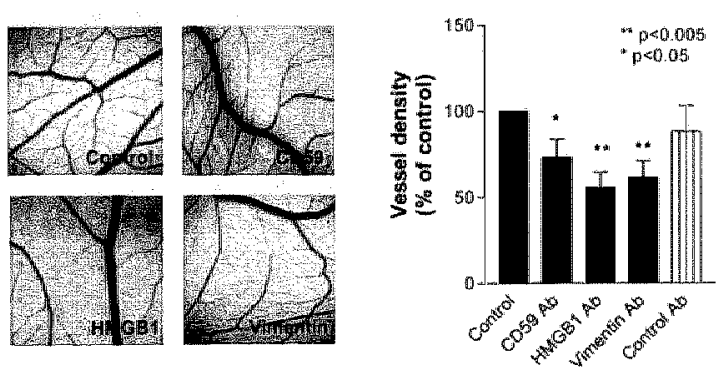

Figure 3.4: Inhibition of in vitro and in vivo angiogenesis by targeting of TAG proteins.

A) Sprout formation (mean \pm SEM) of $B C E$ in a 3D-collagen gel is inhibited by the addition of antibodies $(10 \mu \mathrm{g} / \mathrm{ml})$ directed against different cell surface and secreted TAGs. B) Angiogenesis in the CAM is inhibited by treatment with antibodies $(10 \mu \mathrm{g} / \mathrm{ml})$ directed against the indicated TAGs. Control antibody used is $9 E 10$ anti-myc antibody. 
CD59. HMGB1 and vimentin inhibited angiogenesis by $27 \%, 45 \%$ and $40 \%$, respectively, while a control antibody did not show any activity (Figure 3.4B). These results strongly suggest a role for these molecules in the process of angiogenesis and together with the overexpression on tumor endothelium support their potential for usie in targeting of tumor vasculature as therapy against cancer.

In a subsequent experiment we provided evidence for the validity of our approach to identify endothelial targets that can be used for the treatment of cancer. Athymic mice bearing human LS174T colon carcinoma tumors were treated with the mousereactive $\mathrm{RV} 202$ mouse anti-vimentin antibody. This treatment resulted in a significant dose-dependent inhibition of tumor growth (Figure 3.5A). Since LS174T tumor cells do not express wimentin (Figure $3.5 \mathrm{~B}$, panels a and b), this effect was the result of targeting endothelial vimentin. The latter was supported by the reduced microvessel density (MVD) in the RV202 treated tumors (Figure 3.5B, panels e and f), as compared to MVD in mice treated with controll antibody or saline (Figure 3.5B, panels $c$ and $d$; Figure 3.5C). Furthermore, we showed the binding of injected RV202 antibody to the tumor vasculature (Figure 3.5E), suggesting that activity is mediated through EC vimentin. Treatment with anti-vimentin antibody did not induce toxicity, as determined by normal weight gain (Figure 3.5D) and behavior.

\section{> Discussion}

In the present study, we describe the identification of tumor angiogenesis genes (TAGs) that are overexpressed in tumor EC, also when compared to physiologically activated placental EC. From the series of 17 TAGs we identified several different genes that encoded membrane-bound or secreted proteins. Four of these were selected to investigate their role in angiogenesis and to serve as tumor endothelial target for therapeutic applications. We demonstrated that all four proteins are necessary in the process of anglogenesis and provided proof that TAGs can be used for intervention in angiogenesis and tumor growth using antibodies as a treatment opportunity. A crucial element in designing anti-angiogenic and vascular targeting approaches is the identification of specific target molecules. Some tumor endothelial cell associated markers have been identified $[4-6,25,26]$, but translation to the clinic remains an obstacle. Since angiogenesis is not limited to pathological conditions, careful evaluation of putative targets is warranted to prevent side effects associated with impaired physiological angiogenesis. The followed subtraction strategy provided us with genes that are overexpressed on tumor endothelium but this does not exclude the possibility of expression on other endothelial cells as well. We demonstrated in a mouse tumor model that overexpression on tumor EC provides a therapeutic window that can be used to treat cancer. Alternatively, the used approach also does not exclude the identification of markers that are expressed by tumor cells. It is interesting to speculate that this may even be considered an advantage for therapeutic 
application. Finally, it may be argued that a target can be expressed by other (vascular) cells (e.g. pericytes). Although, the latter scenario applies for this situation too, we demonstrate in the mouse model that injected (anti-vimentin) antibody definitely targets the tumor EC (Figure 3.5E).

Vimentin is an extensively studied intermediate filament protein (reviewed by Hendrix et al. [27]) which has also been described as a target gene of HIF-1a, a major

A

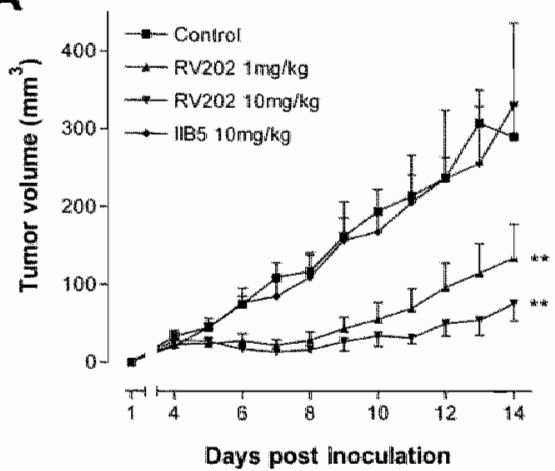

B
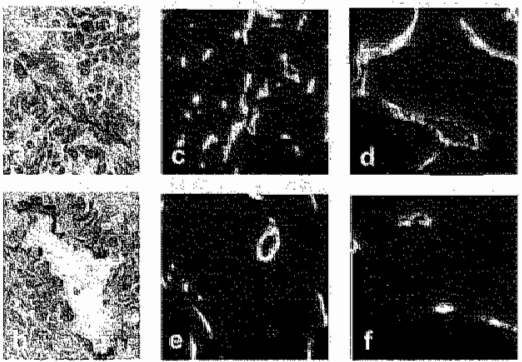

E
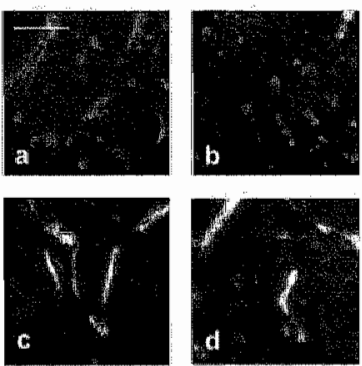

Figure 3.5: Inhibition of tumor growth by targeting tumor endothelial vimentin.

A) Tumor growth curves of LS174T human colon carcinoma tumor xenografts in nude mice, treated with wehicle, IIB5 anti-BrdU isotype matched control antibody (10 mg/kg) or RV202 anti-vimentin antibody (10 $\mathrm{mg} / \mathrm{kg}$ and $1 \mathrm{mg} / \mathrm{kg}$ ). Antibodies were administered every 3 days I.p. for a period of 12 days. A dose-dependent inhibition of tumor growth is evident in mice treated with anti-vimentin antibody ( $1 \mathrm{mg} / \mathrm{kg},{ }^{* *} p<0.0001 ; 10 \mathrm{mg} / \mathrm{kg}$, *" $\left.p<0.0001\right)$, whereas treatment with the isotype control antibody did not show inhibition of tumor growth (IIB5 $10 \mathrm{mg} / \mathrm{kg}_{2} \mathrm{p}=0.6611$ ). B) Immunohistochemical staining of LS174T tumor xenografts in mice with CD31 (a) and anti-vimentin antibody RV202 (b) show that wimentin expression is restricted to the endothelium. Microwessel staining with phycoerythrirn-Habeled CD31 antibody in control mice (c), isotype control antibody treated mice (d), RV202 (1 mg/kg/treatment) (e) and RV202 (10 mg/kg/treatment) treated mice (f). C) Quantification of microvessel density was assessed digitally ( ${ }^{*} \mathrm{p}<0.001$. Student's *test). D) Body weight of mice during treatment, indicating absence of toxicity. E) Detection of treatment antibodies targeted to the tumor endothelium. Mouse antibodies were detected (green fluorescence) in mice treated with saline (a), isotype control antibody (b). RV202 (1 mg/kg/treatment) (c) and RV202 (10 mg/kg/treatment) (d). Endothelial cells are stained with phycoerythrin-labeled anti-CD31 antibody in red. Yellow color indicates co-localization. Scale bar = $25 \mu \mathrm{m}$ 
inducer of VEGF [28]. In different tumor cell lines, vimentin expression has been linked to increased invasiveness $[29,30]$. We have shown quantitative data on the overexpression of vimentin on EC in colon tumor samples compared to normal colon samples, both at the transcriptional level (Figure 3.3A) and the protein level (Figures $3.3 \mathrm{~B}$ and $3.3 \mathrm{C}$ ). These results suggest a contribution of this protein to the tumor endothelial phenotype. We present evidence that targeting of vimentin by means of antibodies clearly inhibits angiogenesis both in vitro and in vivo. In a mouse tumor model, an almost full abrogation of tumor growth was observed. Due to the absence of vimentin on tumor cells in this model (Figure 3.5B, panel b), and the demonstration of homing of injected antibody to the tumor EC (Figure 3.5E, panels $c$ and $d$ ), this was suggested to be caused by a direct effect on tumor angiogenesis. The latter was supported by the marked inhibition of microvessel density. An interesting and as yet not fully elucidated aspect of vimentin is its presumed extracellular localization that makes it targetable using antibodies. Vimentin is an abundant intermediate filament protein in cells of mesenchymal origin. However, it has been shown to be actively secreted in macrophages and to be functionally involved in phagocytosis of bacteria [23]. One might speculate that in tumor endothelium vimentin is associated with integrins $[31,32]$ that mediate its externalization. This cell biological aspect of vimentin awaits further study.

Although HMGB1 was originally identified as a non-histone DNA binding molecule [20], more recently focus has shifted towards its role as a secreted cytokine. As an extracellular protein, it has been involved in the regulation of cell migration [33], tumorigenesis [34], cell activation [21], inflammation [35] and sprouting of EC [13]. Given its role in positive feedback mechanisms in endothelial cell activation, cell migration and invasion, targeting HMGB1 as a means of anti-angiogenic therapy is promising. Here we demonstrated that an antibody directed against HMGB1 was effective at inhibiting endothelial cell sprouting in vitro as well as angiogenesis in vivo.

CD59 is a GPI anchored membrane protein and an inhibitor of complement activation [19]. Cells overexpressing CD59 show resistance to antibody-mediated immunotherapy when complement activation is compromised [19]. Neutralizing CD59 function can improve tumor immunotherapy [36]. Therefore, theoretically, anti-CD59 antibodies may have dual efficacy in vivo, both by inducing complement upon antibody binding and by inhibiting CD59 as a complement inhibitory protein. Complement activation does not apply in vitro, which may explain our result that antibodies directed against CD59 were not readily effective in our in vitro assays. It may well be that targeting of CD59 in vivo is more successful [37]. Indeed, in the in vivo CAM assay we observed a small but significant effect of anti-CD59 antibodies on vessel formation.

IGFBP7 is a secreted protein that accumulates in the basement membrane, where it can bind collagens type II, IV and V, heparan sulfates and different cytokines $[22,38]$. By binding these collagens, it supports the organization of EC into tube-like structures. In addition, IGFBP7 induces prostacyclin secretion from EC, a potent vasodilator that may mediate metastatic spread of tumors [22]. In summary, there is ample evidence 
for an important function of $1 G F B P 7$ in tumor blood vessels. Indeed, we showed that overexpression of IGFBP7 in tumor endothelium was evident both at the transcriptional level and at the protein level. In addition, targeting IGFBP7 with an antibody clearly inhibited endothelial sprouting in vitro, possibly caused by inhibition of the interaction between IGFBP7 and collagens present in the three-dimensional culture matrix.

The extensive bias towards genes functioning in extracellular matrix remodeling among the TAG markers (Figure 3.1C) was also evident in published SAGE data sets of isolated tumor EC that were only compared to normal EC. Genes supposedly playing a role in the initiation of angiogenesis are only rarely identified in gene expression profiling of EC derived from tumors [3-6]. In contrast, gene expression profiling of growth factor stimulated EC and of three-dimensional EC cultures show biases to early events such as cell turnover and cell adhesion, respectively (reviewed by van Beijnum et al. [3]), and can be paralleled with the functional gene distribution in GAG/B and GAG/A, respectively (Figures $3.1 \mathrm{D}$ and $3.1 \mathrm{E}$ ). These differences in global gene expression profiles in EC cultured in witro as compared with isolated EC are likely influenced by differences in microenvironment and duration of stimuli in vitro vs. in vivo. Therefore, extrapolation of data generated by in vitro experiments to the in vivo situation may be limited for it appears difficult to accurately mimic in vitro the complex temporal and spatial actions present in vivo, emphasizing the importance of approaches that make use of more relevant cell sources such as tissue derived cells.

The data presented here demonstrate the presence of genes that show differential expression in tumor angiogenesis compared to physiological angiogenesis which may be sufficient to create a therapeutic window for cancer treatment without inducing significant side effects associated with interference in physiological angiogenesis. The successful targeting of tumor endothelium with antibodies directed at one such TAG, vimentin, and the subsequent inhibition of tumor growth underscores the power of our approach and holds promise for the therapeutic development of the remaining TAGs.

\section{> Acknowledgements}

We thank Susan Joosten and Mat Rousch for technical assistance with endothelial cell selections. This work was supported by a grant from the Research Institute for Growth and Development (GROW), Maastricht University. The study has been financially supported by the sixth EU Framework Programme (Integrated Project 'Angiotargeting'; contract No. 504743) in the area of 'Life sciences, gemomics and biotechnology for health'. 


\section{$>$ References}

[1] Giffioen $A$ W. Molemai $G$. Angiogenesis: potemtials for pharmacologic intervention in the treatiment of cancer, cardiowascular disealses, and chronic inflammation. Pharmacol Rev 2000;52 (2):237-68.

Folkrnan J Tumor angiogenesis. In Holland JF FEl, Bast RC Ji, Kufe DW, Pollock RE, Weichselbaum RR, editor. Cancer Medicine, 5 th Edition. Ontario, Canada: B.C. Decker Inc. 2000. pp. $132-52$.

[3] van Beijnum $\| \mathbb{R}$; Griffioen AW. In silico analysis of angiogenesis associated gene expression identifies angiogenic stage related profiles. Biochim Biophys Acta 2005;1755 (2):121-34.

[4] St Croix $B$, Rago $C$, Velculescu $V$. Trawerso $G$. Romans $K E_{\text {u }}$ Montgomery $E$, Lal $A$, Riggins $G J_{\text {; }}$

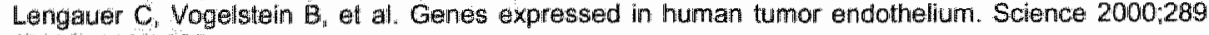
$(5482): 1197 \cdot 202$

[5] Parker BS, Argant $P$, Cook BP, Liangfeng $H_{3}$ Chartrand $S D$, Zhang $M$, Saha $S$, Bardelli $A$, Jiang $Y$, St Martin TB, et al. Alterations in vascular gene expression in invasive breast carcinoma. Cancer Res 2004:64 (21):7857-66.

[6]) Madden SL, Cook BP, Nacht M. Weber WD, Callahan MR, Jiang $Y$, Dufault MR, Zhang $X$, Zhang $W$, Walter-Yohrling $\mathrm{J}$, et al. Vascular gene expression in nonneoplastic and malignant brain. Am I Pathol 2004:165 (2):601-8.

[7] van der Schaft DW, Toebes EA increasing protein (BPI) inhibits angiogenesis via induction of apoptosis in wascular endothelial cells. Blood 2000;96 (1): 176-81.

[8] de Hoon MJ, Imoto S, Nolan J, Miyano S. Open source clustering software. Bioinformatics 2004;20 (9):1453-4.

[9] Thijssen $V L$ Brandwijk RJ, Dings RP, Griffioen AW. Angiogenesis gene expression profiling in xenograft models to study cellular interactions. Exp Cell Res 2004;299 (2):286-93.

[10] Dings RP, Yokoyama Y, Ramakrishnan S, Griffioen AW, Mayo KH. The designed angiostatic peptide anginex synergistically improves chemotherapy and antiangiogenesis therapy with angiostatin. Cancer Res 2003;63 (2):38:2-5.

[11] Szaniszlo P, Wang N, Sinha M, Reece LM, Van Hook JW, Luxon BA, Leary JF. Getting the right cells to the array: Gene expression microarray analysis of cell mixtures and sorted cells. Cytometry $A$ 2004;59(2):191-202.

[12] Humtsoe JO, Feng S, Thakker GD, Yang J, Hong J, Wary KK. Regulation of cell-cell interactions by phosphatidic acid phosphatase 2b/VCIP. Embo J 2003:22 (7):1539-54.

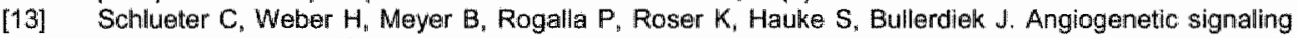
through hypoxia: HIMGB1: an angiogenetic switch molecule. Am J Pathol 2005;166 (4): 1259-63.

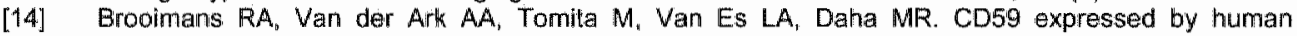
endothelial cells functions as a protective molecule against complement-mediated lysis. Eur $\downarrow$ Immunol 1992; $22(3): 791-7$.

[15] Obermeyer $N_{\text {n }}$ wanson $N$, Bergmann J, Buck $F$. lto WD. Proteone analysis of migrating versus nonmigrating rat heart endothellal cells reveals distinct expression patterns. Endothelium 2003:10 (3): $167-78$.

[16] Pepper MS. Role of the matrix metalloproteinase and plasminogen activator-plasmin systems in angiogenesis. Arterioscler Thromb Vasc Biol 2001;21 (7):1104-17.

[17] Senger DR, Perruzzi CA, Streit M, Koteliansky VE, de Fougerolles AR, Detmar M. The alpha(1)beta(1) and alpha(2)betta(1) integrins provide critical support for vascular endothelial growth factor signaling. endothalial cell migration, and tumor angiogenesis. Am J Pathol 2002; 160 (1):195-204.

[18] Aitkenhead M. Wang SJ, Nakatsu MIN. Mestas J, Heard C. Hughes CC. Identification of endothelial cell genes expressed in an in vitro model of anglogenesis: induction of ESM-1, (beta)ig-h3, and NrCAM Microvasc Res 2002;63 (2):159-71.

[19] Gelderman $K A_{1}$, Tomlinson $S$, Ross $G D$, Gorter $A$. Complement function in mAb-mediated cancer immunotherapy. Trends Immunol 2004:25 (3):158-64.

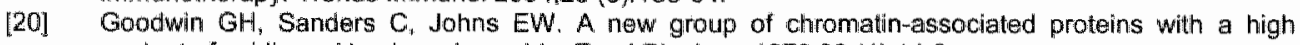
content of acidic and basic amino acids. Eur $J$ Biochem 1973:38 (1):14-9.

[21] Treutiger $C \Downarrow$. Mullins $G E$, Johansson $A S$, Rouhiainen $A *$ Rauwala $H M$, EErlandsson-Harris $H$, Andersson $\mathrm{U}$, Yang $\mathrm{H}$, Tracey $\mathrm{KJ}$, Andersson J, et al. High mobility group $1 \mathrm{Bmbox}$ mediates activation of human endothelum. J Intern Med 2003;254 (4):375-85.

[22] Akaogi $K$, Okabe $Y$, Sato J, Nagashima $Y$, Yasumitsu $H$, Sugahara $K$, Miyazaki $K$. Specific accumulation of tumor-derived adhesion factor in tumor blood vessels and in capillary tube-like structures of cultured vascular endothelial cells. Proc Natl Acad Sci U S A 1996;93 (16):8384-9.

[23] Mor-Vaknin N, Punturieri A, Sitwala K, Markovitz DM. Vimentin is secreted by activated macrophages. Nat Cell Biol 2003:5 (1):59-63. 
[24] Huttunen $H J$, Rauvala $H$. Amphoterin as an extracellular regulator of cell notily from discowery to diseasie. J Intern Med 2004,255 (3):351 I66.

[25] Pasqualini $R_{n}$ Ruoslahti $E$. Organ targeting in who using phage display peptide libraries. Nature $1996 ; 380(6572): 364-6$

[26] Ruoslahti E, Rajotte D. An address system in the vasculature of nomal issues and tumors. Anmu Rew Immunal 2000;18:813-27.

[27) Hendrix MJ. Seftor EA, Chu YW, Trevor KT, Seftor RE Role of intermediate fillaments in imigration, invasion and metastasis. Cancer Metastasis Rev 1996; 15 (4) $1507-25$.

[28] Krishnamachary $B$, Berg-Dixon $S$, Kelly $B$, Agani F, Feldser D, Ferreira $G$, Wen N, LaRusch $d$, Pak $B$, Taghavi $P$, ett al. Regulation of colon carcinoma cell inwasion by hypoxia-inducible factor 1 . Carnoer Res, $2003 ; 63(5): 1138-43$.

[29] Gilles $C$ Polette $M$, Mestdagt $M$, Nawrocki-Raby $B$, Ruggeri $P$, Birembaut P, Foidart JM. Transactivation of wimentin by beta-catenin in human breast cancer cells. Cancer Res 2003,63 $(10): 2658-64$.

[30] Singh $S$, Sadacharan $S$, Su S, Belldegrun A, Persad $S$, Singh $G$. Overexpression of vimentin: role in the invasive phenotype in an androgen-independent modeh of prostate cancer. Cancer Res 2003,63 (9):2306-11.

[31] Maniotis AJ, Chen CS, Ingber DE. Demonstration of mechanical connections between integrins, cytoskeletal filaments, and nucleoplasm that stabilize nuclear structure. Proc Natl Acad Sci U S A $1997 ; 94(3): 849-54$

[32] Gonzales M, Weksler B, Tsumuta D, Goldman RD, Yoon KJ, Hopkinson SB, Flitney FW, Jones JO Stiructure and function of a vimentin-associated matrix adhesion in endothelial cells. Mol Biol Cell 2001;12 (1):85-100.

[33] Fages $C$, Nolo $R$, Huttumen $H J$, Eskelinen $E$, Rauvala H. Regulation of cell migration by amphoterin. J Cell Sci 2000;113 ( Pt 41:611-20.

[34] Taguchi A, Blood DC, dell Toro $G$, Canet $A$, Lee DC, Qu W, Tanji $N$, Lu Y, Lalla E, Fu C, et al. Blockade of RAGE-amphoterin signalling suppresses tumour girowth and metastases. Nature 2000;405 (6784):354-60.

[35] Filuza $C$, Bustin M, Talwar $S$, Tropea $M$, Gerstenberger E, Shelhamer JH, Suffredini AF. Inflammationpromoting activity of HMGB1 on human microvascular endothelial cells. Blood 2003,101 (7):2652-60.

[36] Golay J Lazzari M, Facchinetti $V$, Bernesconi S, Borleri G, Barbui $T$, Rambaldi A, Introna M. CiD20 levels determine the in vitro susceptibility to rituximab and complement of B-cell chronic lymphocylic leukemia: further regulation by CD55 and CD59. Blood 2001;98 (12):3383-9.

[37] Durrant LG, Spendlove I. Immunization against tumor cell surface complementtregulatory proteins. Curr Opin lnvestig Drugs 2001;2 (7):959-66.

[38] Nagakubo D, Murai T, Tanaka T, Usui T, Matsumoto M, Sekiguchi K, Miyasaka M. A high endothelial venule secretory protein. mac25/angiomodulin, interacts with multiple high endolhelial venuleassociated molecules including chemokines. J Immunol $2003 ; 171$ (2):553-61. 
| 82 


\section{Chapter 4}

\section{Interference with vimentin expression affects the angiogenic potential of tumor endothelial cells}

Judy R. van Beijnum, Edith van der Linden, Bernadette M.M. Zwaans, Marjan Harmsma, Frans C.S. Ramaekers \& Arjan W. Griffioen 


\section{$>$ Abstract}

We have previously shown the specific overexpression of vimentin in tumor endothelial cells and the fact that targeting vimentin with antibodies inhibits tumor growth and angiogenesis. Here, we further examine the role of vimentin in endothelial cells. Flowcytometry of non-permeabilized endothelial cells suggests that a cell-surface associated pool of vimentin exists. Surface associated vimentin is inversely related to cell density and regulated by phosphorylation. We found that targeting surface associated vimentin with antibodies and downregulation by RNA interference impairs the ability of endothelial cells to migrate and to form capillary sprouts, while growth and cell viability were unaffected. Finally, antibodies directed against vimentin are capable of reducing vascular density in a model of tumor-induced angiogenesis on the chick chorioallantoic membrane. In conclusion, we provide novel insights in the role of vimentin in angiogenesis and provide proof of its feasibility as targeting molecule for the treatment of cancer. 


\section{$\gg$ Introduction}

Angiogenesis is a hallmark of diverse pathologies such as cancer, rheumatoid arthritis and diabetic retinopathy $[1,2]$. Inhibiting the process is considered to be a promising treatment strategy. The identification of gene products specifically expressed on tumor endothelial cells amenable for targeting may aid in the development of novel molecular imaging approaches and therapeutic modalities for combating cancer.

We have recently identified a series of genes (tumor angiogenesis genes or TAGs) upregulated in tumor endothelial cells (TEC) compared to resting, normal endothelial cells (NEC) as well as physiologically activated placenta endothelial cells (PLEC) by suppression subtractive hybridization ( $\mathrm{SSH}$ ). We identified vimentin as a gene that was overexpressed in TEC compared to both NEC and PLEC, and hence defined it as a tumor angiogenesis gene (TAG) [3].

Vimentin is the major type III intermediate filament protein of mesenchymal cells, including endothelial cells (EC). It is an important structural protein involved in cytoskeletal organization and mechanical transduction of extracellular signals to the nucleus [4]. Expression of vimentin has been associated with different types of cancer. It is used as a tumor marker for the diagnosis of melanoma [5]. In addition, coexpression of cytokeratin and vimentin in epithelial tumors, epithelial-mesenchymal transition (EMT), is indicative of increased aggressiveness [6,7]. Recently, vimentin has been detected as a secreted protein in activated macrophages [8] and as a surface protein on T-lymphocytes $[9,10]$ and neutrophils [11], which may point to a possible more elaborate role for vimentin in angiogenesis than thus far appreciated.

We further investigated the role of vimentin in different aspects of angiogenesis by targeting the protein with antibodies and by modulation of transcript levels with RNA interference and expression constructs. We show that cell survival and proliferation is dependent on the presence of vimentin and that migration and capillary sprouting of $E C$ is mediated by extracellular vimentin. In addition, we show that targeting vimentin with different antibodies inhibits angiogenesis in vitro as well as in vivo. In summary, we provide evidence for an active role for vimentin in angiogenesis and show that interference with the function and expression of the protein affects the angiogenic potential of EC.

\section{>> Materials and Methods}

\section{Cell culture and flowcytometry}

Native HUVEC were obtained by perfusion of umbilical veins with trypsin, allowed to adhere 2 hours to gelatin-coated tissue flasks and harvested by trypsinization. HUVEC, EVLC2 [12] and human microvascular EC (HMEC) were cultured as previously described [13]. Where indicated, okadaic acid (Merck) was added for 16 hours. 
For flowcytometry, cells were fixed in $1 \%$ paraformaldehyde (Merck) for 20 minutes at room temperature or in $70 \%$ ethanol on ice for 20 minutes. Cells were incubated in $25 \mu \mathrm{l}$ reactions with primary antibodies (V9 [DAKO], RV202 [MUbio Products], CD31PE [Serotec], rabbit polyclonal anti-vimentin [MUbio Products]), appropriately diluted in PBS $10.1 \%$ BSA/0.01\% sodium azide. Primary antibodies were detected using biotinylated rabbit-anti-mouse IgG (DAKO) or swine-anti-rabbit IgG (DAKO) in combination with streptavidin-FITC (DAKO). Flowcytometry was performed on a FACS Calibur (BD Biosciences) and data were analyzed using CellQuest ${ }^{\mathrm{TM}}$ software.

Fresh normal colon and colon tumor tissues were obtained from excision surgery at the department of Pathology (University Hospital Maastricht). Tissues were minced with surgical blades, digested with $1 \mathrm{mg} / \mathrm{ml}$ collagenase (Life Technologies), $2.5 \mathrm{U} / \mathrm{ml}$ dispase (Life Technologies) and $100 \mu \mathrm{g} / \mathrm{ml}$ DNAse I (Sigma) at $37^{\circ} \mathrm{C}$ with continuous agitation prior to Ficoll Paque gradient density centrifugation (Amersham). EC were stained with a PE-labeled anti-CD31 antibody (Serotec) and separated from other cells by cell sorting (BD FACSAria).

\section{Real-time quantitative PCR}

EC were isolated from fresh colon tumor tissues, patient-matched normal colon tissues and placental tissues as previously described [3]. SYBR green assays were performed using 10ng cDNA template per reaction, consisting of $1 \times$ SYBR Green Master Mix (Applied Biosystems) and $200 \mu \mathrm{M}$ of each primer (Sigma Genosys,) as previously described [14]. Primers used for amplification of the vimentin transcript were 5'-ACACACTCAGTGCAGCAATATAT-3' and 5'-GGAGTGTCGGTTGTTAAGAACTA-3'.

\section{Vimentin expression constructs and transfection of endothelial cells}

Expression constructs containing vimentin cDNA in the sense and antisense orientation were a kind gift of Dr Scott Su (Hamilton Regional Cancer Centre, Canada) [15]. Vimentin sense cDNA was excised from pCMV-Sport6 using Kpnl/Noll (New England Biolabs) and religated in pcDNA3.1+-hygro (Life Technologies). Vimentin antisense CDNA was recloned to pcDNA3.1+-hygro using Hindll//EcoRI (NEB).

EVLC2 cells were transfected using Nucleofector technology (Amaxa). Briefly, $5 \times 10^{5}$ cells were harvested and resuspended in $100 \mu$ Nucleofector solution R. The cell suspension was mixed with $1 \mu \mathrm{g}$ DNA and transferred to an electroporation cuvette. Following transfection using program T20,500 $\mu$ filtered HUVEC medium was added and cells were transferred to 2 wells of a gelatin coated 24-wells cell culture plate. Successfully transfected cells were selected based on hygromycin resistance using $25 \mu \mathrm{g} / \mathrm{ml}$ hygromycin (Life Technologies).

\section{Proliferation assay}

$5^{*} 10^{3}$ cells were seeded in 96-well cell culture plates coated with $0.2 \%$ gelatin (Merck) and allowed to adhere for 2 hours. Antibodies, dialyzed to PBS to remove 
traces of azide, were added to the culture medium in the indicated concentrations: Cells were cultured for 72 hours. During the last 6 hours of the assay, the culture was pulsed with $0.5 \mu \mathrm{CH}\left[\right.$ methyl- $\left.{ }^{3} \mathrm{H}\right]$-thymidine (Amersham) per well. Activity was measured using liquid scintillation counting (Wallac LSC; PerkinElmer) [13].

\section{Migration assay}

$5^{\star} 10^{3}$ cells were seeded in individual wells of gelatin coated 96 -well cell culture plates and grown to confluence. Using a blunt pipette tip, a cross-shaped wound of approximately $750 \mu \mathrm{m}$ wide was made in the well. Cells were washed with PBS, and fresh medium was added. Where appropriate, dialyzed antibody was added to the medium in the indicated concentrations. Wound width was measured in 4 predefined locations per well at $\mathrm{T}=0,2,4,6$ and 8 hours [13].

\section{Cell cycle analysis}

Cells, including floating cells, were harvested and fixed in $70 \%$ ethanol. Cells were resuspended in DNA extraction buffer $\left(45 \mathrm{mM} \mathrm{Na} 2 \mathrm{HPO}_{4} \cdot 2 \mathrm{H}_{2} \mathrm{O}, 2.5 \mathrm{mM}\right.$ citric acid, $0.1 \%$ Triton- $\times 100, \mathrm{pH} 7.4$ ) (Merck) and incubated at $37^{\circ} \mathrm{C}$ for 20 minutes. Propidium iodide (Merck) was then added to a final concentration of $2 \mu \mathrm{g} / \mathrm{ml}$. Based on DNA content and scatter, cells were classified as dividing (G2/M phase), resting (G1/GO), apoptotic or necrotic [16].

\section{In vitro angiogenesis assay}

Sprouting and tube formation of EC were studied with the use of cytodex-3 beads overgrown with $B C E$ in a $3 D$ gel as previously described [16]. Where appropriate, antibodies dialyzed to PBS were added to the collagen gel and overlay medium in the described concentrations.

Cells were incubated 48 hrs, after which photographs were taken of the beads. Five concentric rings were projected over the photographs, and the number of intersections of rings and sprouting EC was determined and used as a measure of in vitro tube formation.

\section{RNA interference}

Small interfering RNA (siRNA) duplexes were obtained from Eurogentec, one targeting vimentin and one negative control. Cells were transfected using JetSi-ENDO (Eurogentec) according to the manufacturers' instructions. Briefly, 2500 HUVEC were seeded in a gelatin coated 96-well cell culture plate and allowed to adhere overnight. Medium was replaced with DMEM (Life Technologies) containing L-glutamine (Life Technologies). SiRNA-JetSi-ENDO complexes were made by first combining $0.2 \mu l$ JetSi-ENDO with $10 \mu \mathrm{I}$ RPMI 1640 (Life Technologies) per well; this was incubated 20 minutes at room temperature to generate mix A. SiRNA duplexes were added to $10 \mu l$ RPMI-1640 to form mix B. Mix A was added to mix B and incubated at room 
temperature for 30 minutes. Complex $\mathrm{AB}(20 \mu \mathrm{l})$ was added dropwise to the cells and incubated 4 hours. Transfection medium was then replaced with normal medium and cells were grown for 72 hours prior to assaying. BCE were first grown on the cytodex beads as described above, treated with siRNA duplexes and grown for 48 hours prior to being embedded in the collagen gel.

\section{Immunocytochenistry}

HUVEC were cultured on gelatin coated glass coverslips in 24-well cell culture plates. Cells were fixed with $3 \%$ formaldehyde and incubated with anti-vimentin antibody clones V9 (DAKO) and RV202 (Mubio Products). Primary antibodies were visualized using FITC conjugated rabbit-anti-mouse $\operatorname{lgG}$. Cells were subsequently permeabilized to stain nuclei with DAPI (Life Technologies) and actin filaments with phalloidin-TRITC (Life Technologies). Images were obtained using a Zeiss Axioscope fluorescence microscope (Zeiss).

\section{Chick chorioallantoic membrane (CAM) assay}

Fertilized eggs of Lohman-selected White Leghorns were incubated as previously described [13]. At day 10, a silicone ring was placed on the chorioallantoic membrane (CAM) to apply antibody treatment and transplant LS174T spheroids.

LS174T colorectal tumor cells were cultured in DMEM supplemented with $10 \%$ FCS and L-glutamine. Cells were seeded in non-adherent cell culture plates (Greiner Bio-One) at a density of $10^{5}$ cells $/ \mathrm{ml}$ for 10 days to allow spheroids to form. A small surface area (approximately $3 \times 3 \mathrm{~mm}$ ) in the silicone ring placed on the CAM was denudated using lens paper and uniformly looking spheroids of $0.5-1 \mathrm{~mm}$ in diameter were applied on the CAMl. Antibodies were dialyzed to $0.9 \% \mathrm{NaCl}$ and administered in the indicated concentrations in a volume of $65 \mu \mathrm{l}$ for four consecutive days. At day 14, the CAMs were photographed. Five concentric rings were projected on the image. The number of intersections of rings and blood vessels was determined and used as a measure of vessel density.

Sections of the CAMs were excised, formalin-fixed and paraffin embedded. Tissue sections $(5 \mu \mathrm{m})$ were pretreated with xylene and rehydrated in a series of ethanol. Endogenous peroxidase activity was blocked using $\mathrm{H}_{2} \mathrm{O}_{2}$, and sections were boiled in citrate buffer ( $10 \mathrm{mM}, \mathrm{pH} 6.0)$ for antigen retrieval. Sections were incubated with RV202 and primary antibodies were detected with biotinylated rabbit anti-mouse (DAKO) in combination with streptavidin-HRP (DAKO). Antibody-binding was detected using DAB (Sigma).

\section{Statistical analysis}

Results are expressed as mean \pm SEM and statistical significance was assessed using Student's t-test. Experiments were repeated at least three times. Representative examples are shown where applicable. 


\section{$\gg$ Results}

Vimentin expression is induced in activated endothelial cells

Different studies have attempted to profile the gene expression changes associated with tumor angiogenesis in vivo (reviewed by wan Belinum et al. [17]). Major drawback of these studies was that they merely compared gene expression in tumor and normal EC, and did not take into account the gene expression changes associated with physiological angiogenesis. We approached this issue by simultaneously comparing gene expression profiles of tumor endothelial cells (TEC), isolated from fresh colon tumor tissues, with the gene expression profiles of nomal, resiting endothelial cells (NEC) isolated from fresh normal colon tissues, and with that of angiogenically activated placenta endothelial cells (PLEC) [3]. We performed SSH in combination with cDNA array screening and identified vimentin as a transcript that was overexpressed in colon TEC compared to NEC and angiogenic PLEC [3].

We validated the expression differences in these different endothelial cell sources by real-time quantitative PCR. Vimentin is significantly overexpressed in TEC as compared to both PLEC and NEC (Figure 4.1A). Vimentin expression on colon tumor and normal colon EC was assessed on CD31 positive cells sorted from single cell suspensions by FACS to determine whether the observed changes in mRNA levels

A

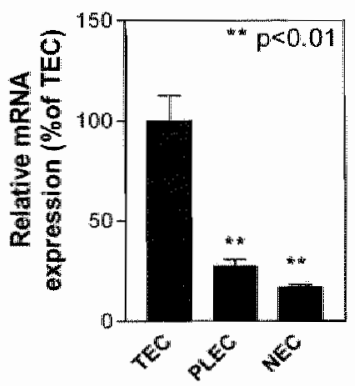

B

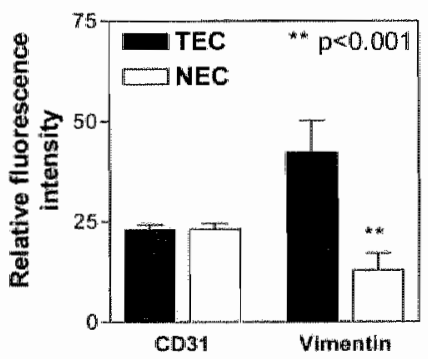

C

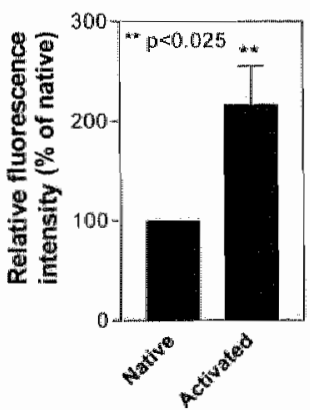

Figure 4.1: Vimentin expression in endothelial cells of different origins.

A) Vimentin MRNA expression was assessed by real-time quantitative PCR and normalized to cyclophilin A transcript levels. Endothelial cells (EC) were isolated from fresh colon tumor tissuess (TEC). patient-matched normal colon tissues (NEC) and placental tissues (PLEC) using antibodycoated paramagnetic beads as previously described [3]. Vimentin MRNA expression is significantly higher in TEC compared to angiogenically activated PLEC and resting NEC. B) Vimentin protein expression on EC in viwo was assessed by flowcytometry of sorted EC from fresh colon tumor tissues and patient-matched normal collon tissues. CD31 expression did not differ between tumor EC and normal EC, whereas vimentin expression on turnor $E C$ is significantly increased. C) Direct isolates of umbilical vein EC (native) were compared with HUVEC cultured in the presence of angloglenic additional growth factors (activated). Total vimentin expression was assessed by flowcytometry and shown to relate to the activation status of the EC. 
were correlated to protein levels. Indeed, colon tumor EC expressed significantly more vimentin protein than normal colon EC whereas CD31 expression did not differ (Figure 4.1B), strongly suggesting fumor-driven induction of vimentin on EC in vivo. As HUVEC are frequently used in angiogenesis research, we investigated the expression of vimentin in cultured and native, directly isolated, HUVEC by flowcytometry. The expression of vimentin was significantly higher in HUVEC that had been cultured for several days when compared to HUVEC directly isolated from umbilical cords (Figure 4.1C), suggesting that increased vimentin expression is also associated with activation of $\mathrm{EC}$ in vitro.

To determine whether vimentin would be a relevant targeting candidate molecule on EC, we determined its accessibility for antibodies using different fixation methods and flowcytometry. Cells were either fixed with $1 \%$ paraformaldehyde to detect surface associated protein [18], or fixed with permeabilizing $70 \%$ ethanol to detect total cellular vimentin. We used two monoclonal antibodies directed against vimentin, clones $V 9$ and RV202, and these showed comparable results on HUVEC (Figure 4.2A), EVLC2 and HMEC (data not shown). Flowcytometry shows that all EC abundantly express vimentin (Figure $4.2 \mathrm{~A}$, left panel), but that a percentage of the EC also has detectable vimentin when fixed with paraformaldehyde (Figure 4.2A, right panel), suggesting membrane-associated vimentin is present on EC.

We further investigated the expression of vimentin an EC grown in monolayers. In contrast to permeabilized, ethanol fixed cells that all displayed abundant vimentin intermediate filament staining throughout the cytoplasm (Figure 4.2B, panel a), in nonpermeabilized formaldehyde fixed EC we observed membranous staining in a

Figure 4.2: Vimentin expression is detected on the surface of endothelial cells and is inversely associated with cell density.

A) EC were either fixed with $1 \%$ paraformaldehyde or with $70 \%$ ethanol. Vimentin expression was assessed by flowcytometry using two different anti-vimentin monoclonal antibody clones, $v 9$ and RV202. A clear difference in immunoreactivity is observed. B) Immunofluorescence of HUVEC growing in monolayer. Abundant vimentin expression is detected in permeabilized cells (panel a), whereas a subpopulation of formaldehyde fixed cells showed membranous (panel b) as well as patchy staining of vimentin at the cell periphery (panel c). Scale bar $=10 \mu \mathrm{m}$. C) Surface associated vimentin expression on EC is associated with cell density. Confluent, contact-inhibited EC express considerably less vimentin on their surface, measured by flowcytometry of $1 \%$ paraformaldehyde fixed cells, as compared to non-conflluent, exponentially growing $\mathrm{EC}$ (left panels). Total cellular vimentin detected in $70 \%$ ethanol fixed cells by flowcytometry did not differ between confluent and non-confluent cells (right panels). D) Effect of okadaic acid treatment on vimentin expression. HUVEC were treated with different concentrations of the phosphatase inhibitor okadaic acid and cell surface associated wimentin was assessed by flowcytometry of paraformaldehyde fixed cells and increases with increasing okadaic acid concentrations (left $y$-axis), in contrast to $70 \%$ ethanol fixed cells (right $y$-axis). PF: $1 \%$ paraformaldehyde fixation; EtOH: $70 \%$ ethanol fixation. 
A

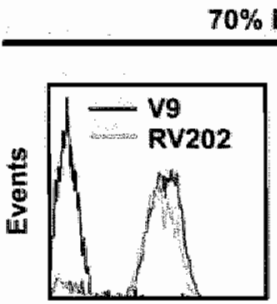

FLI-H

B

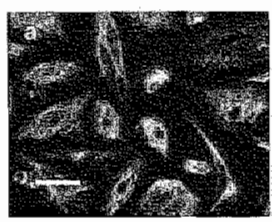

C

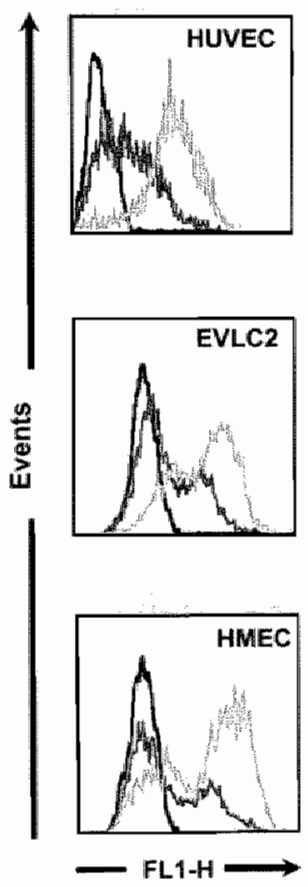

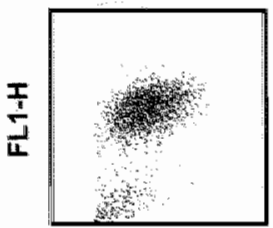

FSC.-H
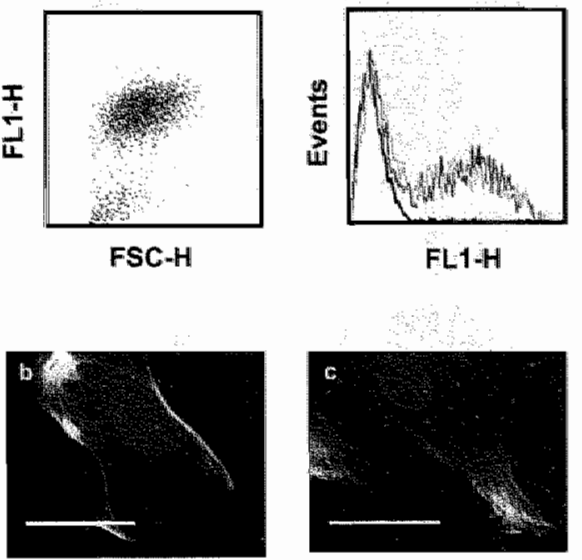

FL14H

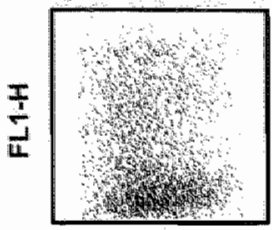

$\mathrm{FSCH}$

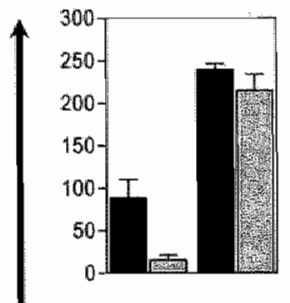

- Confluent
$=$ Non-confluent

D

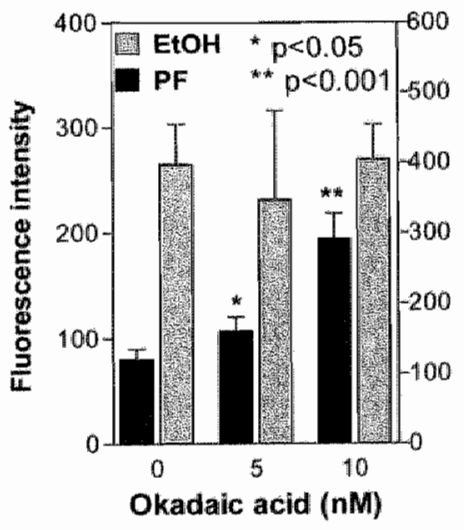


subpopulation of cells (Figure $4.2 \mathrm{~B}$, panel b). In addition, a patchy staining was observed at the edges of the cells (Figure $4.2 \mathrm{~B}$, panel c). The observation that vimentin expression was increased in activated EC made us investigate whether surface associated vimentin expression would be related to cell density. EC grown in culture become contact inhibited once cell density has reached its maximum. Indeed, as shown by flowcytometry, vimentin antibody immunoreactivity of paraformaldehyde fixed cells was markedly increased in non-confluent, exponentially growing EC. In contrast, no difference in vimentin expression was detected in permeabilized cells (Figure 4.2C). Vimentin can be phosphorylated on serine by diverse protein kinases [19-21], and in macrophages this has been associated with increased secretion [8]. We tested whether surface accessible vimentin was dependent on protein phosphorylation. Okadaic acid is a phosphatase type $2 \mathrm{~A}$ inhibitor and treatment of EC with okadaic acid increased the amount of vimentin detected by flowcytometry on paraformaldehyde fixed cells, but did not affect the total amount of vimentin (Figure 4.2D), suggesting surface associated expression might be related to vimentin phosphorylation status.

\section{Knockdown of vimentin expression primarily inhibits migration and sprouting}

To test the influence of vimentin expression levels in EC on their angiogenic properties in vitro, we stably transfected EVLC2 cells with expression vectors containing vimentin cDNA in either the sense or the antisense orientation [15] to increase or reduce vimentin expression, respectively (Figure 4.3A). Growth curves of the transfected cells indicated that EVLC2 harboring the antisense construct were not viable. Also, ectoplically expressed vimentin did not stimulate the growth of the EC compared to mon-transfected control or empty vector transfected cells (Figure 4.3B). This indicated that vimentin is essential for EC survival and growth, but that induced overexpression does not further contribute to these processes.

A

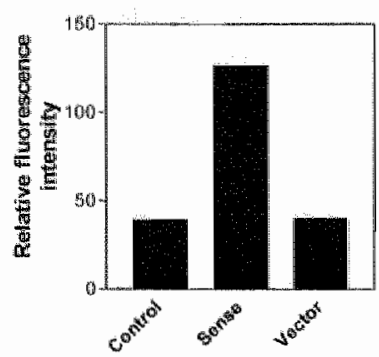

B

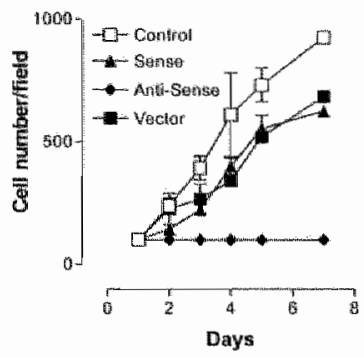

Figure 4.3: Transfection of full-length vimentin does not affect endothelial cell growth but antisense expression of vimentin is lethal.

A) EVLC2 cells were stably transfected with expression vectors expressing full-llength vimentin CDNA in either the sense or antisense orientation under control of a CMV promoter. Expression of fulllength vimentin constructs increased the expression of

vimentin as assessed by flowcytometry. B) Cell proliferation of transfected EVLC2 was assessed. Cell growth was to a limited extent affected by transfection of the vector. EC transfected with the anti-sense construct were not viable. 
To circumvent problems associated with lethality after complete knockdown of vimentin by the antisense expression construct, we employed RNA interference to transiently knockdown vimentin expression in HUVEC. Different concentrations of siRNA duplexes were tested for their effect on vimentin protein expression, as effective knockdown is dependent on protein abundance and turnover dynamics, as well as on cell type [22]. Vimentin siRNA duplexes or control siRNA duplexes were introduced in HUVEC and vimentin expression was assessed by flowcytometry after 72 hrs on both ethanol fixed and paraformaldehyde fixed cells. Total vimentin expression was only reduced by $10 \%$ using 50 nM siRNA duplex (Figure $4.4 \mathrm{~A}$ ), whereas vimentin detecled on paraformaldehyde fixed cells was reduced by almost $60 \%$ (Figure 4.2B), suggesting that the surface associated vimentin fraction is primarily affected upon partial protein knockdown by RNA interference. Using higher concentrations of siRNA duplexes, both total cellular vimentin (Figure 4.4A) and surface associated vimentin (Figure 4.4B) were downregulated by approximately $50 \%$. Proliferation of EC was significantly inhibited upon $50 \%$ reduction of total vimentin levels (Figure $4.4 \mathrm{C}$ ). In addition "total cell death in HUVEC was significantly increased (Figure 4.4D). Treatment of HUVEC with $50 \mathrm{nM}$ vimentin siRNA duplex, resulting in downregulation of the surface detectable but to a minimal extent total vimentin, did not affect the cell death or proliferation (Figures $4.4 \mathrm{C}$ and D), suggesting that a certain level of vimentin is required for EC viability. In contrast, a reduction in surface associated vimentin by $50 \mathrm{nM}$ vimentin SiRNA duplex already significantly decreased EC migration (Figure 4.4E), indicating that surface associated vimentin is critically involwed in this process. Finally, capillary sprouting was also inhibited by $50 \mathrm{nM}$ vimentin siRNA duplex (Figure 4.4F). Taken together, these data point to an important role for surface associated vimentin in EC migration and capillary tube formation, but also indicate that threshold levels of vimentin expression are required for EC viability and survival.

\section{Targeting vimentin inhibits angiogenesis in vitro and in vivo}

The accessibility of vimentin for antibodies in non-permeabilized cells allows targeting of this protein in in vitro and in (pre-)clinical settings. We therefore investigated the effect of the presence of anti-vimentin antibodies on EC migration and sprouting. Both clone V9 (Figure 4.5A) and clone RV202 (Figure 4.5B) significantly inhibited HUVEC migration. A control IgG did not affect EC migration. The presence of V9 in the culture medium did not affect HUVEC proliferation as assessed by ${ }^{3} \mathrm{H}=$ thymidine incorporation (Figure $4.5 \mathrm{C}$ ). We further investigated the role of extracellular vimentin on angiogenesis in an in vitro angiogenesis modell. Sprouting of BCE in a collagen gel was significantly inhibited by the presence of antibodies directed at vimentin (Figure $4.5 \mathrm{D}$ ). 
A

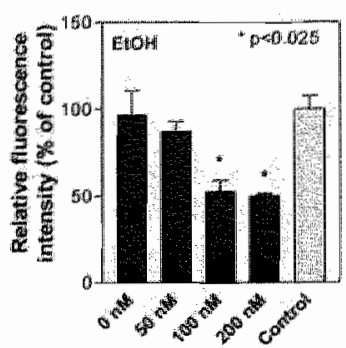

B

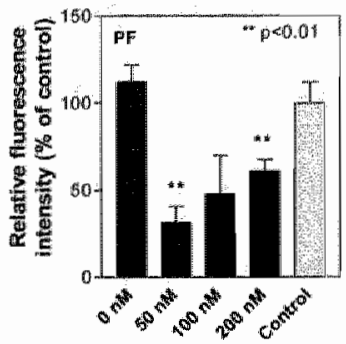

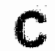

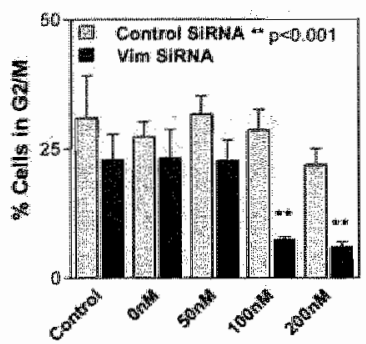

D

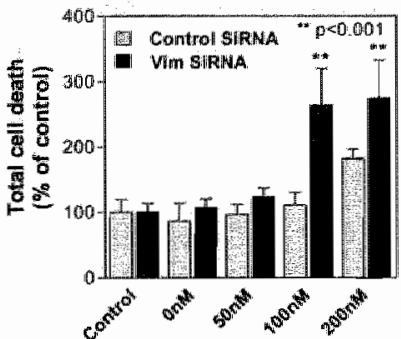

E

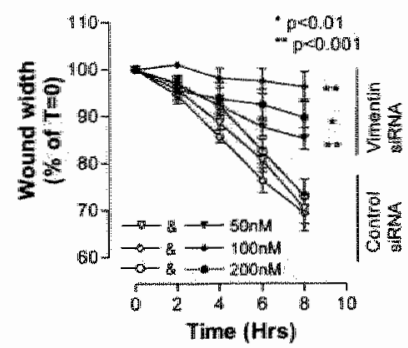

$\mathbf{F}$

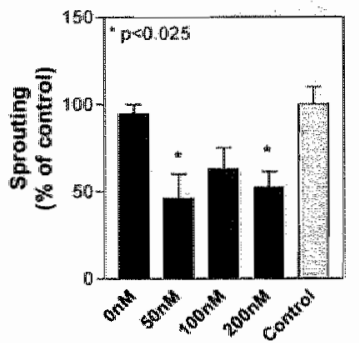

Figure 4.4: Inhibition of vimentin expression by RNA interference affects the angiogenic potentlal of endothelial cells.

HUVEC were transiently transfected with siRNA duplexes directed against vimentin. A) Vimentin expression was decreased with increasing vimentin siRNA duplex concentrations as determined by flowcytometry of ethanol (EtOH) fixed cells. B) Surface expression of vimentin on paraformalidehyde (PF) fixed cells was significantly decreased in response to low dose siRNA treatment. C) Downregulation of total vimentin but inot surface associated vimentin leads to a decrease in the fraction of dividing cells (black bars). No effects of identical concentrations of non-relevant siRNA duplexes were obsenved (grey bars). D) Downregulation of total vimentin by siRNA (black bars) but not of surface associated vimentin leads to endothelial cell death. No significant effects of identical concentrations of non-relevant siRNA duplexes were observed (grey bers). E) Downregulation of vimentin surface expression by siRNA inhibits the capacity of EC to migrate into a wounded area. F) Capillary sprouting of EC was markedly inhibited by downregulation of surface associated vimentin. Control samples in A), B) and (F) were treated with RPMI only. Non-relevant control duplex had no inhibitory effect on vimentin expression or on EC sprouting (data nat shown).

To provide an in vivo model of tumor angiogenesis, human LS174T colon carcinoma cell line spheroids were transplanted onto the CAM. This resulted in a markedly induced vasculature with a distorted morphology (Figure 4.6A), whereas the vasculature in the CAM distant from the tumor appears normal (Figure 4.6B). Immunostaining of sections of CAMs with anti-vimentin antibodies shows specific staining of vessels in the membrane, as compared to a control antibody (Figures 4.6E and 4.6D, respectively). Anti-vimentin antibodies were capable of reducing LS174T spheroid induced vasculature (Figure $4.6 \mathrm{C}$ ). CAMs treated with the antibody still show inorphologically abnormal vasculature (Figure $4.6 \mathrm{C}$, inset) but the vascular density is 
reduced to approximately normal levels (Figure 4.6F). These data indicate that targeting vimentin by means of extracellularly applied antibodies reduced the angiogenic potential of EC in vitro and the tumor induced angiogenic response in vivo.

\section{> Discussion}

Vimentin is the major intermediate filament protein of mesenchymal cells and its expression can be regulated by HIF-1 $\alpha$ [23], $\beta$-catenin/TCF [24], VEGF [25] and Twist [26]. Co-expression of vimentin and keratin (EMT) in diverse types of tumor cells has been associated with increased malignancy as a result of increased motility and invasiveness $[6,7]$. Vimentin expression was shown to be elevated in tumor EC compared to resting EC as well as physiologically activated $E C$, which suggests a functional contribution of this protein that is advantageous to tumor progression and/or survival. Downregulation of vimentin by an antisense expression construct proved lethal in EC, though upregulation by expression vectors did not affect cell growth (Figure 4.3B).
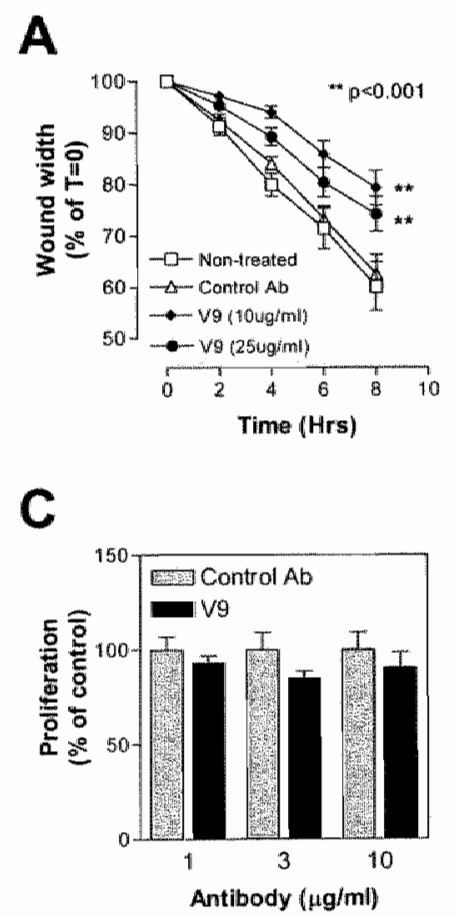

B

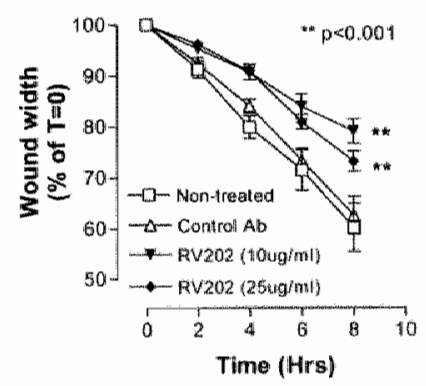

D

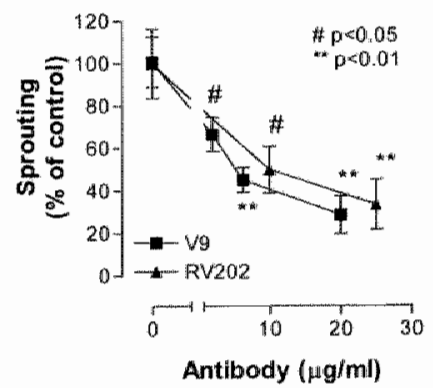

Figure 4.5: Targeting surface accessible vimentin with antibodies inhibits endothelial migration and sprouting.

A, B) Two different antibodies reactive with vimentin were added to wounded cultures of HUVEC. Migration into the wounded area was significantly inhibilted by both V9 (A) and RV202 (B). C) Antibodies reactive with vimentin added to the culture did not affect endothelial cell viability and prollferation. D) Capillary sprouting in a 3D collagen matrix was dose-dependently inhibited by both antivimentin monoclonal antibodies. 
Aggressive tumor cell lines tend to express more vimentin than non-aggressive tumor cell lines $[15,27,28]$. However, transfection of vimentin in non-aggressive, hormone-responsive LNCaP prostate cancer cells alone was not sufficient to increase invasiveness in vitro. In contrast, downregulation of vimentin by transfection of aggressive, hormone-refractory CL1 prostate cancer cells with a vimentin antisense expression construct inhibited migration and invasion in vitro [15]. In a model of EMT in breast carcinoma cells it was shown that vimentin is specifically induced in migrating epithelial cells and that vimentin expression levels were correlated with migration speed [29]. Again, transfection of these cells with a vimentin expression construct did not increase migration, whereas downregulation of vimentin reduced the migration speed of the cells [29].
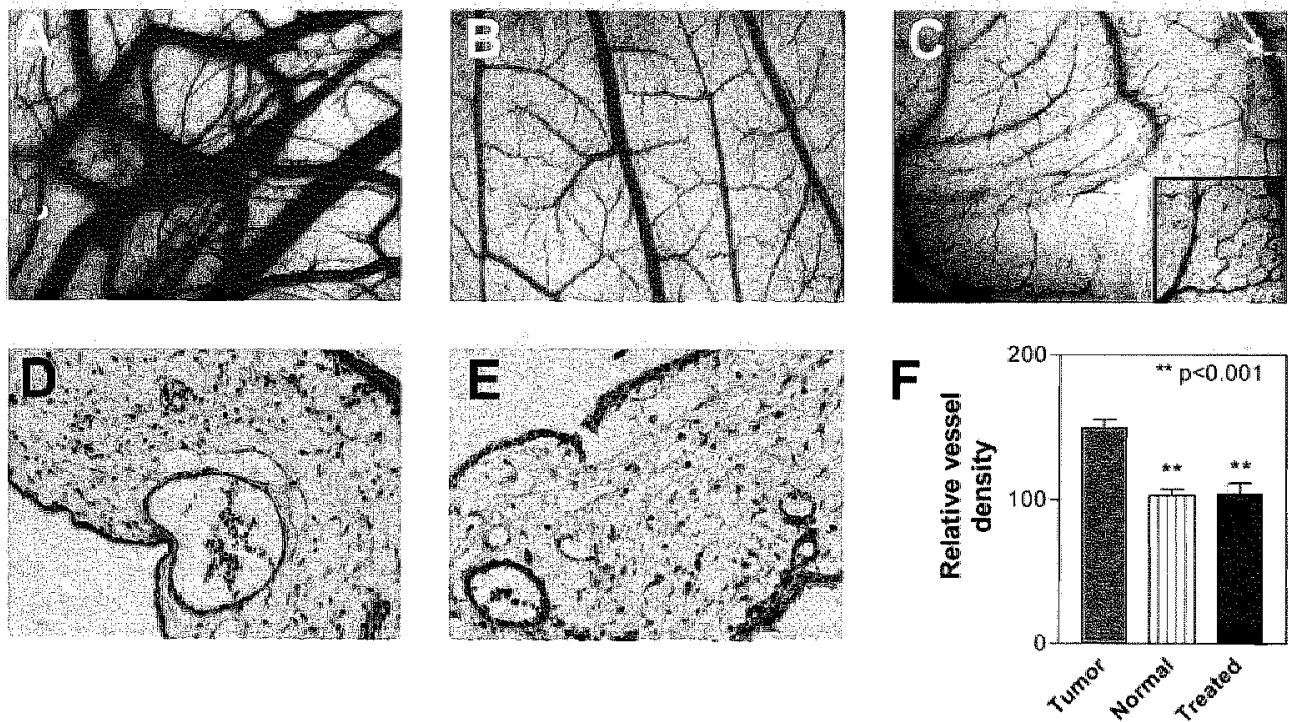

Figure 4.6: Targeting vimentin with antibodies inhibits tumor angiogenesis in an in wivo model of the chick chorioallantoic membrane.

A) LS174T human colon tumor cell spheroids were grown on the chick CAM and markedly induced vasculature with a disorganized appearance. B) Untreated sections of the CAM distant from the growing tumor cells show a normal vascular density and morphology. C) Treatment of the CAMs with RV202 reduced the extent of the tumor-induced vasculature. Morphological examination of these vessels shows thin and tortuous vessels that are composed of loops (inset). D, E) Immunohistochemical staining of paraffin embedded lissue sections of CAMs show no staining in the control (D) whereas RV202 specifically immunostained vessels in the chick CAM (E). F) Treatment of LS174T tumors growing on CAMs significantly reduced vascular density to normal levels. 
Our data indicate that EC express cell surface associated vimentin, as shown by both flowcytometry and immunofluorescence. Dowregulation of this fraction by SIRNA interfered with EC migration and capillary sprout formation but did not affect cell growth and survival. Marked downregulation of total cellular vimentin compromised cell proliferation and survival and was finally lethal, suggesting a threshold level of vimentin is required in EC. Thus, cell surface associated vimentin plays an important role in EC migration and sprouting, but does not influence EC viability. The presence of surface accessible vimentin on tumor EC makes this protein a putative targeting molecule. We have previously shown the success of targeting endothelial vimentin in a mouse tumor model [3]. Here, we showed that antibody mediated targeting of vimentin inhibited EC migration and tube formation but not proliferation in vitro and tumor-induced angiogenesis on the CAM in vivo. Thus, these results support a crucial role for cell surface accessible endothelial vimentin in angiogenesis. Indeed, recently it is becoming more and more apparent that vimentin expression is not restricted to the cytoplasm. The presence of vimentin reactive auto-antibodies in autoimmune diseases [30-32] and following transplantation [33] also suggests that certain pools of vimentin are accessible to the immune system, hence are present in the extracellular milieu. In fact, several immune effector cells have been shown to express vimentin at the cell surface, but its physiological significance is as yet unknown $[9,11]$. Interestingly, vimentin is actively secreted from activated macrophages, and involved in the process of phagocytosis of bacteria [8].

Surface associated vimentin is reduced upon contact inhibition of cells, and increased in the presence of phosphatase inhibitors, pointing towards a phosphorylation dependent process by which vimentin is presented on the cell surface. Phosphorylation of vimentin leads to reorganization of the intermediate filaments. Vimentin can be phosphorylated on serine residues by different kinases, e.g. p21 activated kinase (PAK), Rho kinase (ROK) $\alpha$, protein kinase $A(P K A)$, protein kinase $C$ (PKC), and cell division cycle (CDC) 2 kinase [19-21,34]. CDC42 and Rac1 have been described to play a major role in EC migration via modulation of integrin $\alpha V \beta 3$ [35]. A downstream target of Rac1 is PAK, which promotes the formation of lamellipodia $[19,20]$, a process that hence may involve vimentin phosphorylation. Interactions between vimentin and different integrins and its presence in focal adhesions have been demonstrated in different studies [36-38], and mediate the transduction of mechanical signals to the nucleus. In addition. ROK $\alpha$ increases the number of focal adhesion, structures where integrins associate with the supporting extracellular matrix [19]. Vimentin filaments are wrapped around $\alpha \mathrm{V} \beta 3$ integrins, in association with plectin, in so-called vimentin associated matrix adhesions (VMAs) in EC $[37,38]$. These VMAs were assembled in migrating cells and induced by growth factors, and partially disassembled in contact-inhibited cells [37]. Vimentin also interacts with $\alpha 2 \beta 1$ integrins, again more pronounced in spread cells than in confluent cultures [36]. PKC $c$-mediated phosphorylation of vimentin is involved in the recycling integrin $\beta 1$. During this process integrin $\beta 1$ is present in endosomal vesicles along with $\mathrm{PKC} \varepsilon$ and vimentin [34]. The 
importance of vimentin organization by kinases was demonstrated by the observation that overexpression of vimentin in PKC $\varepsilon-1$ - cells did not increase cell motility in contrast to wild-type cells [34]. Recently, vimentin was shown to be involved in transendothelial migration of peripheral blood mononuclear cells (PBMC), and vimentin of both cell types was required for stabilization of the interaction [39]. Furthermore, lymphocytes of vim- - mice had markedly reduced integrin $\beta 1$ levels and vim- $/$ - endothelial cells expressed reduced levels of ICAM1 and VCAM1, suggesting the involvement of vimentin in positioning adhesion molecules for interactions [39]. One might speculate that vimentin may become cell surface exposed in EC as a consequence of modulating the expression and/or position of integrins and that this is dependent on phosphorylation by specific protein kinases. The reorganization of vimentin filaments and the redistribution of adhesion molecules contribute to an increased angiogenic potential. The $\mathrm{N}$-terminal domain of vimentin can interact with negatively charged phospholipid bilayers [40], providing a putative anchor for the protein on the cell surface. However, the precise externalization of vimentin and its role in cell motility and angiogenesis awaits further study.

In conclusion, we have shown that vimentin expression is increased in angiogenically activated $\mathrm{EC}$ and that interference with surface associated vimentin fraction results in inhibition of endothelial migration and tube formation, as well as with tumor-induced angiogenesis in wivo. This surface accessibility and its functional contribution to tumor angiogenesis make it a valuable target for antiangiogenic anticancer therapeutics. 


\section{$>$ References}

[1] Folkman J. Tumor angiogenesis. In: Holland JF FEl, Bast RC Jr. Kufo DW, Pollock RE. Weichselbaum RR editor. Cancer Medicine, 5th Edition. Ontario, Canada: B.C. Decker inc., 2000. pp. $132-52$

[2] Griffioen AW, Molema G. Angiogenesis: potentials for pharmacologic intervention in the treatment of cancer, cardiovascular diseases, and chronic inflammation. Phamacol Rev 2000,52 (2):237-68.

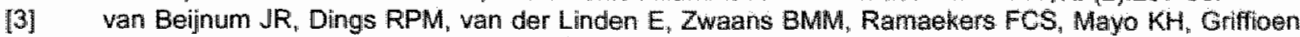
AW. Gene expression tumor angiogenesis dissected; specific tangeting of tumor endothelium. Submitted.

[4] Maniotis AJ, Chen CS, Ingber DE. Demonstration of mechanical connections between integrins, cytoskeletal filaments, and nucleoplasm that stabilize nuclear structure. Proc Natl Acad Sci U S A 1997:94 (3):849-54.

[5] Huszar $M_{s}$ Halkin $H$. Herczeg $E_{1}$ Bubis $J$, Geiger $B$. Use of antibodies to intermediate filaments in the diagnosis of metastatic amelanotic malignant melanoma. Hum Pathal 1983:14 (11):1006-8.

[6] Hendrix MJ, Seftor EA, Chu YW. Seftor RE, Nagle RB, McDaniel KM, Leong SP, Yohem KH, Lebovitz $\mathrm{AM}$, Meyskens $\mathrm{FL}, \mathrm{Jr}$, et al. Coexpression of vimentin and keratins by human melanoma tumor cells: correlation with invasive and metastatic potential. J Natl Cancer Inst 1992;84 (3):165-74.

[7] Ramaekers $F_{n}$ Haag D, Kant A, Moesker $O$, Jap PH, Vooijs GP. Coexpression of keratin- and vimentin-type intermediate fillaments in human metastatic carcinoma cells. Proc Natl Acad Sci U S A $1983 ; 80(9): 2618-22$.

[8] Mor-Vaknin N, Punturieri A, Sitwala K, Markovitz DM. Vimentin is secreted by activated macrophages. Nat Cell Biol 2003;5 (1):59-63.

[9] Boilard E, Bourgoin SG, Bernatchez C, Surette ME. Identification of an autoantigen on the surface of apoptotic human $T$ cells as a new protein interacting with inflammatory group IIA phospholipase A2. Blood 2003;102 (8):2901-9.

[10] Huet D, Bagot M, Loyaux D, Capdevielle J, Conraux L, Ferrara P, Bensussan A, Marie-Cardine A. SC5 mAb represents a unique tool for the detection of extracellular vimentin as a specific marker of Sezary cells. J Immunol 2006;176 (11):652-9.

[11] Moisan $E_{1}$ Girard D. Cell surface expression of intermediate fillament proteins vimentin and lamin $B \|$ in human neutrophil spontaneous apoptosis. J Leukoc Biol 2005.

[12] van Leeuwen EB, Veenstra $R$, van Wijk $R$, Molema $G$, Hoekstra A, Ruiters MH, van der Meer J. Characterization of immortalized human umbilical and liac vein endotheliall cell lines after transfection with SV40 large T-antigen. Blood Coagul Fibrinolysis 2000;11 (1):15-25.

[13] van der Schaft DW, Dings RP, de Lussanet QG, van Eijk LI, Nap AW, Beets-Tan RG, Bouma-Ter Steege JC, Wagstaff J, Mayo KH, Grifficen AW. The designer anti-angiogenic peptide anginex targets tumor endothelial cells and inhibits tumor growth im animal models. Faseb J 2002;16 (14): 1991-3.

[14] Thijssen VL. Brandwijk RJ, Dings RP, Griffioen AW. Angiogenesis gene expression profiling in xenograft models to study cellular interactions. Exp Cell Res 2004;299 (2):286-93.

[15] Singh $S$, Sadacharan $S$, Su $S$, Belldegrun $A$, Persad $S$, Singh $G$. Overexpression of vimentin: role in the inwasive phenotype in an androgen-independent model of prostate cancer. Cancer Res 2003;63 (9):2306-11.

[16] van der Schaft DW. Toebes EA, Haseman JR, Mayo $\mathrm{KH}$, Griffioen AW. Bactericidal/permeabilityincreasing protein (BPI) inhibits angiogenesis via induction of apoptosis in vascular endothelial cells. Blood 2000;96 (1): 176-81.

[17] van Beijnum JR, Griffioen AW. In silico analysis of angiogenesis associated gene expression identifies angiogenic stage related profiles. Biochim Biophys Acta 2005;1755 (2):121-34.

[18] Rouhiainen $A$, Kuja-Panula $d$, Wikman $E$, Pakkanen $J$ Stenfors J, Tuominen $R K$, Lepantalo $M$, Carpen O, Parkkinen J, Rauvala H. Regulation of monocyte migration by amphoterin (HMGB1). Blood 2004:404 (4):1174-82

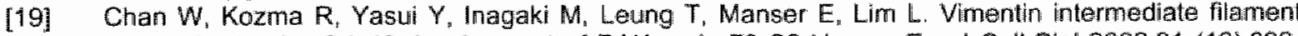
reorganization by Cdc42: involvement of PAK and p70 S6 kinase. Eur J Cell Biol 2002;81 (12);692701

[20] Goto $H$, Tanabe $K_{\text {, Manser }} E_{,}$Lim L, Yasui $Y$, Inagaki M. Phosphorylation and reorganization of wimentin by p21-activated kinase (PAK), Genes Cells 2002;7 (2):91-7.

[21] Ermakowa S, Choi BY. Choi HS, Kang BS, Bode AM, Dong $Z$. The intermediate filament protein vimentin is a new target for epigallocatechin gallate. J Biol Chem 2005:280 (17):16882-90.

[22] Chatteriee-Kishore M. Miller CP. Exploring the sounds of silence: RNAil-mediated gene silencing for target identification and validation. Drug Discow Today 2005;10 (22):1559-65.

[23】 Krishnamachary B, Berg-Dixon S, Kelly B, Agani F, Feldser D, Ferreira G, lyer N, LaRusch J, Pak B, Taghavi $P$, et al. Regulation of colon carcinoma cell invasion by hypoxia-inducible factor 1 . Cancer Res $2003 ; 63(5): 1138-43$. 
24) Glles C. Polette $M$; Mesidagt M. Nawrocki-Raby $B$, Ruggeri $P$, Birembaut $P$, Foidart JM. Transactivation of vimentin by bete-caterin in human breasi cancer cells Cancer Res 2003;63 $(10): 2858-64$

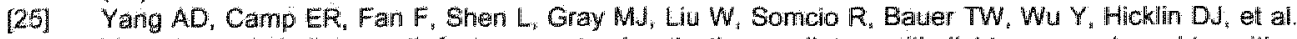
Vascular endotheliat growth factor receptor-1 actiwation mediates epithelial to mesenchymal transition in human pancheatic carcinoma cells. Cancer Res 2006,66 (1):46-51.

(26) Mironchik $Y$. Winnard PT, Jr, Vesuna $F$, Kato $Y$, Wildes F, Pathak. AP, Kominsky $S$, Artemov $D$; Bhujwalla 2, Van biest $P$, a l. Twist overexpression induces in vivo angiogenesis and correlates with chromosomal insitability in breast cancer. Cancer Res $2005 ; 65$ (23) 1080119 .

[27) Sommers $C L$. Walker-jones $D$, Heckford $S E$, Worland $P$. Valverius $E$, Clark $R$, McCormick $F$, Stampfeit M, Abularach $S$, Gelmann EP. Vimentin rather than keratin expression in some hormoneindependent breast cancer cell lines and in oncogene-transformed mammary epithellal cells. Cancer Res $1989 ; 49(15): 4258-63$

[281 Thompson EW, Paik S, Brunner $N$, Sommers CL, Zugmaier $G$, Clarke $R$, Shima TB. Torr J, Donahue S, Lippman ME, el al. Assiociation of increased basement membrane invasiweness with absence of estrogen receptor and expression of vimentin in human breast cancer cell lines. $₫$ Cell Physiol $1902: 150(3): 5344-4.4$.

129] Giltes $C$, Polette $M_{1}$ Zahm JM, Toumier JM, Volders $L$. Foidart JM, Birembaut $P$. Vimentin contributes to human mammary epithelial cell migration. J Cell Sci 1999;112 ( Pt 24):4615-25.

[30] Wossenaar ER, Despres M, Lapointe E, van der Heijden A, Lora M, Senshu T, wan Ventooi WJ, Menard HA. Rheumatold arthritis specific anti-Sa antibodies target citrullinated vimentin. Arthritis Res Ther 2004:6 (2):R142-50.

[31] won Mikecz A, Konstantinow K, Buchwald DS, Gerace L, Tan EM. High frequency of autoantibodies to insoluble cellular antigens in patients with chronic fatigue syndrome. Arthritis Rheum 1997;40 (2):295305

[32] Franch $A$, Castellote $C_{\text {, Vila }}$ ل ل Vilaro $S$, Casteil M. Anticytoskeletal autoantibody development In ad juwant arthritis. I Rheumatol 1994,21 (3):489-97,

[33] Jonker $M_{8}$ Danskine $A_{\text {, Heansitra } K} K_{n}$ Wubben $J_{y}$ Kondova I, Kuhn EM, Rose M. The autoimmune response to vimentin after renal transplantation in nonhuman primates is immunosuppression dependent. Transplantation 2005;80 (3):385-93.

[34] Waske J, Vuoriluoto $K$, Huovinen T, kawa I, lnagaki M, Parker PJ. PKCepsilon-medlated phosphorylation of vimentin controls imtegrin recycling and motility. Embo J 2005:24 (22):3B34-45.

[35] Dormond $O$. Foletti $A$, Paroz $C$ "Ruegg $C$. NSAIDs inhibit alpha $V$ beta 3 integrin-mediated and Cdc42/Rac-dependent endothelial-cell spreading, migration and angiogenesis. Nat Med 2001;7 (9): $1041-7$.

[36] Kreis S, Schonffeld HJ, Melchior C, Steiner B, Kieffer $N$. The intermediate flament proten vimentin binds specifically to a recombinant integrin alpha2/beta1 cytoplasmic tail complex and co-localizes with native alphazbeta1 in endothelial cell focal adhesions. Exp Cell Res 2005;305 (1):110-21.

[37] Gonzales M. Weksler B. Tsuruta D, Goldman RD, Yoon KJ, Hopkinsion SB, Flitney FW, Jones JC. Siructure and function of a vimentin-associated matrix adhesion in endothelial cells. Mol Biol Cell 2001:12(1):85-100.

[38] Tsuruta D. Jones JC. The vimentim cyloskeleton regulates focal contact size and adhesion of endothelial cells subpected lo shear stress. J Cell $5 c 12003 ; 116$ (Pt 24):4977-84.

[39] Nieminen M, Henttinen T, Merinen M, Martilla-Ichihara F, Eriksson JE Jakanen S. Vimentin function in lymphocyle adhesion and transcellular migration. Nat Gell Biol 2006.

[40] Perides $G$, Harter $C$, Traul $P$. Electrostatic and hydrophobic interactions of the intermediate filament proten vimentin and its amino terminus with lipid bilayers. J Bial Chem 1987,262 (28):13742-9. 


\section{Chapter 5}

\section{High-mobility group box 1 (HMGB1) positively contributes to tumor angiogenesis}

Judy R. van Beijnum, Edith van der Linden \& Arjan W. Griffioen 


\section{> Abstract}

High-mobility group box 1 (HMGB1) was originally identified as a chromatinbinding molecule, though it has later been recognized as a cytokine. We identified HMGB1 to be overexpressed in tumor endothelial cells. By modulating expression and function we demonstrate that HMGB1 is involved in diverse aspects of the angiogenic process. Overexpression of HMGB1 in endothelial cells increased migration and MMP9 expression, whereas downregulation of HMGB1 by antisense cDNA resulted in an impaired response to angiogenic growth factors and decreased angiogenic sprouting. Furthermore, antibodies directed against HMGB1 inhibited endothelial migration and sprouting in vitro but did not impact growth factor induced proliferation. In the chick chorioallantoic membrane assay anti-HMGB1 antibodies were found to inhibit tumorinduced angiogenesis. The present results indicate a significant role in tumor angiogenesis and may identify HMGB1 as a potential target for anti-angiogenesis or vascular targeting anti-tumor therapy strategies. 


\section{> Introduction}

Angiogenesis is pivotal to processes where new tissue growth is required. In addition to the development and progression of cancer, new blood vessel growth is also involved in the development of other pathologies, including atherosclerosis and diabetic retinopathy. The concept of inhibiting angiogenesis as a treatment strategy for cancer has gained widespread interest over the last decades. To develop specific antiangiogenic or vascular targeting agents, detailed insight in the phenotype of tumor endothelial cells (TEC) is required. We have recently conducted a gene expression survey to identify genes overexpressed in TEC compared to both resting, normal endothelial cells (NEC) and angiogenic placenta endothelial cells (PLEC), and identified high-mobility group box 1 (HMGB1) as a tumor angiogenesis gene (TAG) [1].

HMGB1 was first discovered as a chromatin binding protein [2]. It interacts with DNA and bends it, to facilitate interaction with diverse transcription factors, such as p53 [3]. Years later, it was identified as a membrane-bound protein that facilitates the outgrowth of neurites [4]. More recently, HMGB1 has been recognized as a late mediator of endotoxin lethality in mice [5] and many studies have focussed on its role as an inflammatory cytokine since. The primary receptor for HMGB1 is the $\lg$ superfamily member called receptor for advanced glycation end products (RAGE), though it can also bind toll-like receptor (TLR) 2 and TLR4 [6]. Advanced glycation end products (AGE) are formed during periods of hyperglycemia in diabetic individuals and AGE-RAGE interactions contribute to vascular complications such as retinopathy and nephropathy in diabetes $[7,8]$. HMGB-RAGE signaling has been implicated in inflammation and cancer progression (reviewed by Bierhaus et al. [9]). HMGB1 is abundantly present in many cancers and blocking HMGB1-RAGE interactions by using anti-HMGB1, anti-RAGE and signaling-deficient RAGE molecules resulted in decreased tumor growth in a glioma model [10]. Here, we identify HMGB1 as an active player in tumor angiogenesis. HMGB1 expression is induced in TEC and tumorconditioned HUVEC. Furthermore, interference with HMGB1 expression and function affects migration and sprouting of endothellal cells and the proliferative response to angiogenic factors. Finally, we show that tumor angiogenesis in vivo is inhibited by anti-HMGB1 antibodies. The role of HMGB1 in the progression of cancer is hereby extended from a previously predominant role in tumor cells themselves towards an additional role for endothelial HMGB1.

\section{> Materials and methods}

\section{Cell culture}

HUVEC were obtained by perfusion of umbilical veins with trypsin. EC were cultured in RPMI-1640 (Life Technologies) supplemented with 20\% heat-nactivated human serum, glutamine and penicillin/streptomycin (Life Technologies) in gelatin 
coated tissue flasks. Where indicated, $1 \mathrm{ng} / \mathrm{ml}$ bFGF (Reliatech) and $10 \mathrm{ng} / \mathrm{ml}$ VEGF (Reliatech) were added. Tumor-conditioned HUVEC (HUVEC+) were supplemented with $10 \%$ conditioned medium of Caco-2 and LS174T in addition to bFGF and VEGF. HUVEC were cultured under quiescent conditions by reducing the serum concentration to $2 \%$. Colon tumor cell lines were cultured in DMEM (Life Technologies) supplemented with $10 \%$ heat-inactivated fetal calf serum.

\section{Real-time quantitative PCR}

Cultured cells were harvested by trypsinization. EC were isolated from fresh collon tumor tissues, patient-matched normal colon tissues and placental tissues as previously described [1]. RNA was isolated using RNeasy-mini spin collumns (Qiagen) according to the manufacturers' instructions. cDNA was reverse transcribed using MMLV-RT (Bio-Rad) according to the manufacturers. instructions. SYBR green assays were performed using 10ng CDNA template per reaction, consisting of $1 \times$ SYBR Green Master Mix (Bio-Rad) and $200 \mu \mathrm{M}$ of each primer (Sigma Genosys) as previously described [11]. Primers used for amplification of the HMGB1 transcript were 5'TCTAAGAAGTGCTCAGAGAGGTG $-3^{\prime}$ and 5'- TTCATITCTCTITCATAACGGG-3', for MMP2 5'-AGATGCCTGGAATGCCAT-3' and 5'-GGTTCTCCAGCTTAGGTAAT-3', and for MMP9 5'-TACTGTGCCTTTGAGTCCG-3' and 5'-TTGTCGGCGATAAGGAAG3'.

\section{Flowcytometry}

EC were cultured as described. Cells were fixed in $70 \%$ ethanol on ice for 30 minutes and incubated in $25 \mu$ reactions with primary antibodies [mouse anti-HMGB1 (Sigma)] appropriately diluted in PBS/0.1\% BSAV0.01\% sodium azide $/ 0.05 \%$ triton $X$ 100. Primary antibodies were detected using biotinylated rabbit-anti-mouse lgG (DAKO) in combination with streptavidin-FITC (DAKO).

Fresh normal colon and colon tumor tissues were obtained from excision surgery at the department of Pathology (University Hospital Maastricht). Single-cell suspensions were prepared as described previously [1]. Endothelial cells were stained with a PE-labeled anti-CD31 antibody (Serotec) and separated from other cells by cell sorting (BD FACSAria; BD Biosciences). Sorted cells were incubated with rabbit antiHMGB1 (kind gift of R.G. Roeder, Rockefeller University, NY) and subsequently with biotinylated swine anti-rabbit lgG (DAKO) in combination with streptavidin-FITC (DAKO). Cells were analyzed on a flowcytometer (FACS Calibur; BD Biosciences) and acquired data was analyzed using CellQuest ${ }^{\mathrm{TM}}$ software.

\section{Immunofluorescence}

EVLC2 were grown in gelatin coated 96-well cell culture plates. Cells were fixed on ice with $70 \%$ ethanol and permeabilized with $0.05 \%$ triton $X-100$ in PBS. Cells were incubated with mouse anti-HMGB1 (Sigma) and subsequently with biotin conjugated rabbit anti-mouse lgG (DAKO). Fluorescent label was provided by streptavidin-FITC. 
Images were acquired under an inverted microscope equipped with a fluorescence unit (Leica).

\section{Constructs and transfection of endothelial cells}

HMGB1 open reading frame was amplified from HUVEC CDNA (using 5:GGGCACTGGGCGACTCTGTG-3' and 5'-ACTGCGCTAGAACCAACTTATTC-3') and inserted in pCDNA3-Hygro (Life Technologies) using Hindll and Xhol restriction enzymes (New England Biolabs).

EVLC2 cells, SV40 large T-antigen transformed HUVEC [12] were transfected using Nucleofector technology (Amaxa). Briefly, $5^{*} 10^{5}$ cells were harvested and resuspended in $100 \mu$ Nucleofector solution $R$. The cell suspension was mixed with 1 $\mu \mathrm{g}$ DNA and transferred to an electroporation cuvette. Following transfection using program T20, $500 \mu$ filtered HUVEC medium was added and cells were transferred to 2 wells of a gelatin coated 24-wells cell culture plate. Successfully transfected cells. were selected based on hygromycin resistance using $25 \mu \mathrm{g} / \mathrm{ml}$ hygromycin (Life Technologies). Cell growth was monitored by seeding $5^{\star} 10^{3}$ cells per well in gelatincoated 96-well plates and counting the number of cells per field in 4 locations of the wells.

\section{Antisense oligodeoxynucleotides (ODNs)}

Where indicated, $5 \mu \mathrm{M}$ antisense ODNs were added to the culture for 72 hours. Phosphorothioate-modified oligonucleotides were designed using Antisense Design from IDT SciTools (http://www.idtdna.com/SciTools/SciTools.aspx) according to previously published guidelines [13]. The following ODNs were used: 5'AGGATCTCCTTTGCCCAT-3' (HMGB1 ODN) and 5'-TCCCTAGTGACTCTTCC-3' (control ODN) (Eurogentec).

\section{Migration assay}

$5^{\star} 10^{3}$ cells were seeded in individual wells of gelatin coated 96-well cell culture plates and grown to confluence. Using a blunt pipette tip, a cross-shaped wound of approximately $750 \mu \mathrm{m}$ wide was made in the well. Cells were washed with PBS, and fresh medium was added. Where appropriate, antibody dialyzed to PBS (to remove traces of azide) was added to the medium in the indicated concentrations. Wound width was measured at 4 predefined locations per well at $T=0,2,4,6$ and 8 hours.

\section{Proliferation assay}

$5^{*} 10^{3}$ cells were seeded in 96-well gelatin-coated cell culture plates and allowed to adhere for 2 hours. Antibodies, dialyzed to PBS, were added to the culture medium in the indicated concentrations. Cells were cultured for 72 hours. During the last 6 hours of the assay, the culture was pulsed with $0.5 \mu \mathrm{Ci}$ [methyl- ${ }^{3} \mathrm{H}$ ]-thymidine (Amersham) per well. Activity was measured using liquid scintillation counting (Wallac LSC; PerkinElmer) [14]. 
In vitro angiogenesis assay

Sprouting and tube formation of EC were studied with the use of cytodex-3 beads overgrown with BCE in a 3D gel as previously described [14]. Where appropriate, antibodies dialyzed to PBS were added to the collagen gel and overlay medium in the described concentrations.

Cells were incubated 48 hours, after which photographs were taken of the beads. Five concentric rings were projected over the photographs, and the number of intersections of rings and sprouting endothelial cells was determined and used as a measure of in vitro tube formation.

Alternatively, a tumor blood vessel was prepared free from its surrounding tumor mass and sections of approximately $2 \mathrm{~mm}$ in length were embedled in collagen as described above. Tissue sections were incubated for 7 days in the presence of bFGF and VEGF to induce sprout formation.

\section{Chick chorioallantoic membrane (CAM) assay}

Fertilized eggs of Lohman-selected White Leghorns were incubated for 3 days at $37^{\circ} \mathrm{C}, 55 \%$ relative air humidity, while being rotated every hour. At day 3 , a rectangular window $(1 \times 1.5 \mathrm{~cm})$ was made in the shell. Albumin $(2 \mathrm{ml})$ was withdrawn through the blunt end of the egg. The window was covered with transparent tape to prevent dehydration, and the eggs were further incubated without rotation until day 10. At day 10, a silicone ring was placed on the chorioallantoic membrane (CAM) to apply antibody treatment and transplant LS174T spheroids.

LS174T were seeded in non-adherent cell culture plates (Greiner Bio-One) at a density of $10^{5}$ cells $/ \mathrm{ml}$ for 10 days to allow spheroids to form. A small surface area (approximately $3 \times 3 \mathrm{~mm}$ ) in the silicone ring placed on the CAM was denudated using lens paper and uniformly looking spheroids of $0.5-1 \mathrm{~mm}$ in diameter were applied on the CAM. Antibodies were dialyzed to $0.9 \% \mathrm{NaCl}$ and administered in a volume of $65 \mu l$ for four consecutive days. At day 14, the CAMs were photographed. Five concentric rings were projected on the image. The number of intersections of rings and blood vessels was determined and used as a measure of vessel density.

Pleces of the CAMs were excised, formalin-fixed and paraffin embedded. Tissue sections (5um) were pretreated with xylene and rehydrated in a series of ethanol. Endogenous peroxidase activity was blocked using $\mathrm{H}_{2} \mathrm{O}_{2}$, and sections were boiled in citrate buffer (10mM, pH6.D) for antigen retrieval. Sections were incubated with mouse anti-HMGB1 (Sigma) and primary antibodies were detected with biotinylated rabbit anti-mouse (DAKO) in combination with streptavidin-HRP (DAKO). Antibody binding was detected using DAB (Sigma). 


\section{Results}

\section{HMGB1 expression in endothelial cells}

Suppression subtractive hybridization (SSH) in combination with cDNA array screening identified HMGB1 to be overexpressed in colon tumor endothelial cells (TEC) as compared to both activated placenta endothellal cells (PLEC) and resting endothelial cells derived from normal colon (NEC) [1]. Differential gene expression levels were validated by means of quantitative real-time PCR on MRNA derived from HUVEC cultured under activating or sillencing conditions and from TEC, NEC and PLEC. As shown in figure 5.1, mRNA expression of HMGB1 is augmented in activated HUVEC (Figure 5.1A) and in TEC as compared to NEC and PLEC (Figure 5.1B). Furthermore, we observed considerable heterogeneity in HMGB1 expression among different colon tumor cell lines, as well between different endothelial cells.

A

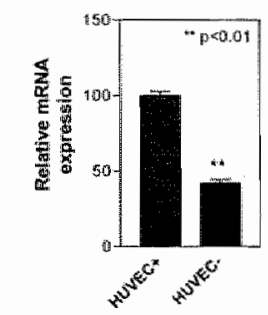

E

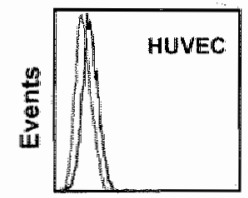

B

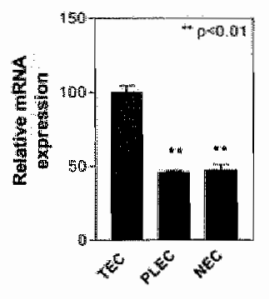

C

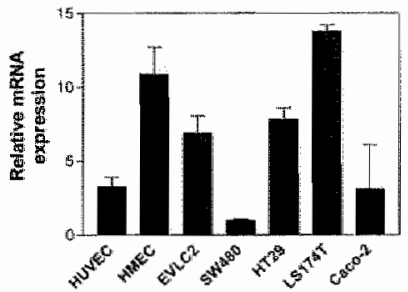

$\mathbf{F}$
D
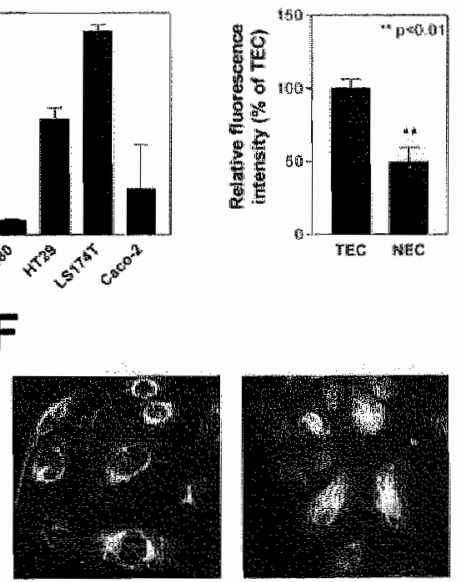

Figure 5.1: HMGB1 expression in endothelium.

A) Real-time quantitative PCR (RTQ-PCR) on fumor-conditioned HUVEC (HUVEC+) and quiescent HUVEC (HUVEC-). Expression levels were normalized against cyclophilin A transcript expression and expressed as percentage of expression in HUVEC+. B) RTQPCR on endothelial cells isolated from colon tumors (TEC), normal colon (NEC) and placenta tissues (PLEC). Expression levels were normalized against cyclophilin $A$ transcript expression and expressed as a percentage of the expression in TEC. C) RTQ-PCR analysis of HMGB1 expression in diverse colon tumor cell lines (SW480, HT29, LS174T and CaCo-2) and different types of endothelial cells (HUVEC, HMEC, EVLC2). Expression levels were normalized against cyclophilin A transcript expression and expressed relative to HMGB1 expression levels in SW480. D) HMGB1 protein expression levels in CD31 positive colon tumor endothelial cells and patient-matched normal colon endothelial cells assessed by flowcytometry. Expression levels of CD31 did not differ between TEC and NEC (data not shown). E) HMGB1 protein expression levels in HMEC and EVLC2 assessed by flowcytometry. A low to moderate expression of HMGB1 is detected in all cells. F) Immunofluorescence analysis of HMGB1 expression in EVLC2 cells. Scale bar $=10 \mu \mathrm{m}$. 
HMEC, endothelial celis of microvascular origin, expressed more HMGB1 than HUVEC and EVLC2, both of macrovascular origin (Figure 5.1C). We subsequently verified that mRNA levels represented protein levels in vivo. FACS analysis on CD31 positive cells was performed on síngle-cell suspensions from colon tumor and normal colon tissues. HMGB1 expression was considerably higher in TEC than in NEC (Figure 5.1D), whereas CD31 expression did not differ (data not shown). Thus, HMGB1 is upregulated in activated and tumor endothelial cells. Flowcytometry also confirmed low levels of HMGB1 protein expression in cultured endothelial cells (Figure 5.1E). Protein localization was assessed using immunofluorescence of cells grown in monolayers. We observed nuclear staining but also cytoplasmic staining (Figure 5.1F), that has previously been associated with secretion of the protein [15].

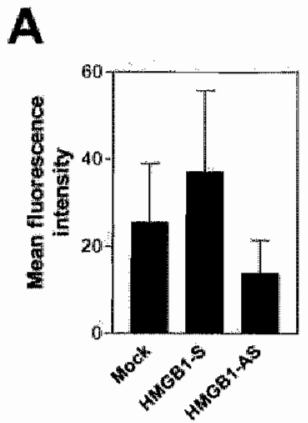

D

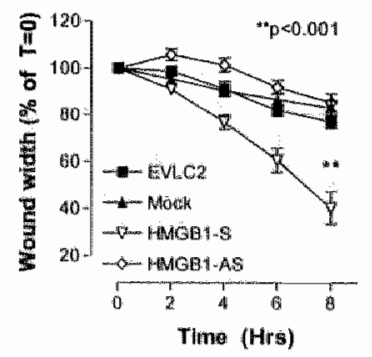

B

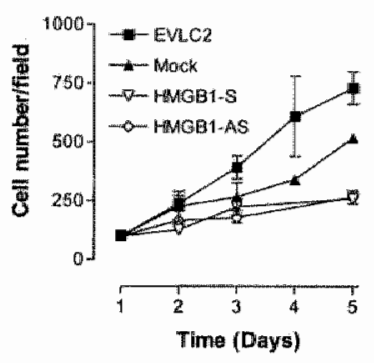

$\mathbf{E}$

Figure 5.2: Effects of HMGB1 sense and antisense expression constructs.

A) EVLC2 cells were stably transfected with expression constructs harboring the open reading frame of HMGB1 either in the sense (HMGB1-S) or in the antisense (HMGB1-AS) orientation. Flowcytometry of transfected cells demonstrates increased and reduced HMGB1 protein levels in these cells respectively as compared to mock transfected cells. B) Cell growth of both HMGB1-S and HMGB1-AS is impaired compared to control cells, but do not differ from each other. C) HMGB1-AS expressing cells have an impaired ability to respond to angiogenic growth factors as shown by a decreased proliferation rate. Basal proliferation is not affected. "* $p<0.01$ towards EVLC2 cells. D) Overexpression of HMGB1 increases the capacity of EVLC2 cells to migrate into a wounded area. Reduced HMGB1 expression only mimimally reduces migration. E) RTQ-PCR analysis of HMGB1-S and HMGB1-AS transfected cells. HMGB1 mRNA expression is clearly reduced in HMGB1-AS transfected cells compared to HMGB1-S transfected cells (left). MMP2 expression is equal in both HMGB1-S and HMGB1-AS transfected cells (middle). MMP9 expression is induced in HMGB1-S transfected cells (right). 


\section{Modulation of HMGB1 expression affects angiogenesis}

To address the significance of these findings, we employed different techniques to modulate the expression levels of HMGBI in EC to determine the exact roles of HMGB1 in different aspects of angiogenesis. The open reading frame of HMGB1 was cloned in either the sense (HMGB1-S) or the antisense (HMGB1-AS) orientation in an expression vector to achieve up- or downregulation of the protein, respectively. Expression levels of HMGB1 protein were assessed by flowcytometry following stable transfection of EVLC2 cells (Figure 5.2A). Both HMGB1-S and HMGB1-AS transfected EVLC2 demonstrated impaired growth characteristics as compared to control cells, suggesting altered HMGB1 expression affects EC biology (Figure 5.2B). However, in contrast to HMGB1-S expressing cells, HMGB1-AS expressing cells were not capable of increasing their proliferative rate upon stimulation with angiogenic factors (Figure 5.2C). HMGB1 also affected the migrational capacity of EVLC2 in a wounding assay. Cells overexpressing HMGB1 showed faster closure of a wounded monolayer, but downregulation of HMGB1 levels had only minor inhibitory effects on EC migration (Figure 5.2D). HMGB1 mRNA has previously been reported to be upregulated in migrating cells $s_{n}$ and downregulated upon contact inhibition [16], linking HMGB1 expression levels with the migrational capacity of cells. Migration and invasion are highly dependent on the degradation of the surrounding matrix by MMPs. Membranebound HMGB1 can, via tissue plasminogen activator (tPA), activate MMPs that facilitate matrix degradation [17], and AGE-RAGE signaling induces MMP2 and MMP9 mRNA expression [18]. We thus investigated the expression of MMP2 and MMP9 in transfected cells. No differences in MMP2 mRNA levels were detected between HMGB1-S and HMGB1-AS, but MMP9 expression was induced approximately 3-fold in HMGB1-S (Figure 5.2E).
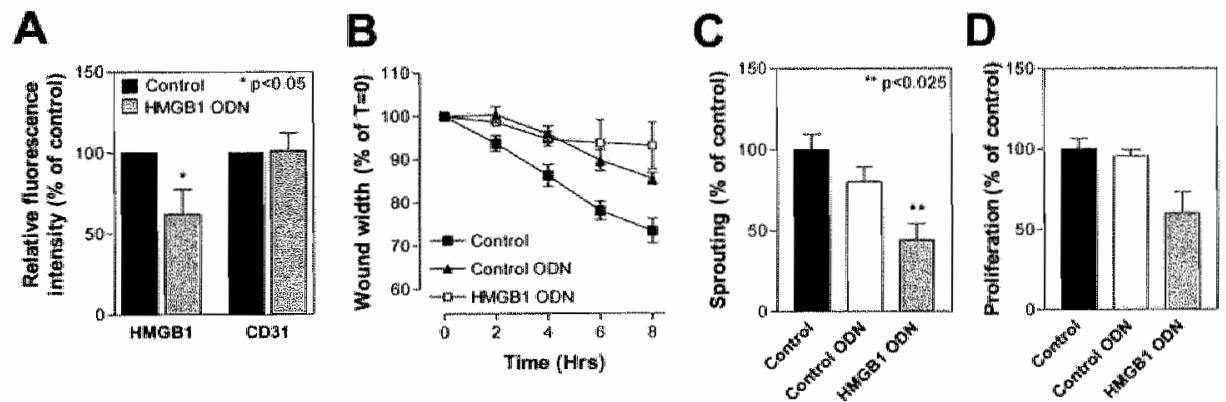

Figure 5.3: Effects of HMGB1 antisense ODNs on the angiogenic properties of EC.

A) EC were treated with $5_{\mu M}$ antisense ODN for 72 hours. Expression of HMGB1 was specilfically downregulated by HMGB1 ODNs but not by control ODNs. The expression of CD31 was not affected. B) HMGB1 antisense oligadeoxynucleotides (ODNs) inhibited the migration of EC into a wounded area, though this did not differ significantly from the non-relevant control ODN. C) HMGB1 ODNs significantly inhibited sprouting of EC. The control ODN only marginally inhibited EC sprouting. D) HMGB1 ODNs inhibited the proliferation of $\mathrm{EC}_{\mathrm{i}}$ whereas a control $\mathrm{ODN}$ did not. 
An alternative strategy for protein knockdown that does not necessarily require cell transfection is the use of ODNs $[19,20]$. Indeed, a FITC-labeled non-rellevant ODN added to the culture was readily taken up by EC (data not shown). Using a HMGB1specific ODN (Figure 5.3A), we observed inhibition of EC migration (Figure 5.3B) and sprouting (Figure 5.3C), though in some cases a considerable effect was observed in the presence of a non-specific control ODN, indicative of off-target effects. Growth factor induced prolferation was inhibited in HMGB1 ODN treated EC (Figure 5.3D), which is in concordance with the data obtained using the expression constructs.

\section{Antibody targeting of HMGB1 intibits endothelial cell migration and sprouting}

EC can secrete HMGB1 when stimulated with LPS and TNF $\alpha$, which is preceded by cytoplasmic expression of the protein [15]. Membrane-bound HMGB1 has been involved in the outgrowth of neurites and anti-HMGB1 antibodies inhibited this process $[17,21]$. Though we could not detect HMGB1 protein on intact cells (data not shown) the detection of HMGB1 in the cytoplasm of EC made us investigate whether antiHMGB1 antibodies would affect the angiogenic capacity of endothelial cells. AntiHMGB1 antibodies did not affect growth factor induced proliferation of endothelial cells (Figure 5.4A), but did inhibit migration (Figure 5.4B). In addition, we tested the effect on tube formation of BCE in a matrix of collagen. Sprouting of BCE was clearly inhibited by antibodies directed against HMGB1 (Figure 5.4C and D). In an ex wivo approach, tumor blood vessels were prepared free from their surrounding cell mass and $2 \mathrm{~mm}$ sections were embedded in collagen. Small vessel sprouts were induced by bFGF and VEGF in the controls, but treatment with anti-HMGB1 antibodies inhibited the sprouting (Figure 5.4E). This inhibitory effect of antibodies implicates an extracellular rolle for HMGB1 in endothelial migration and sprout formation [16].

\section{Anti-tumor treatment using anti-HMGB1 antibodies}

The effect of targeting HMGB1 using antibodies was tested in an in vivo tumor angiogenesis model using the CAM. LS174T tumor cells spheroids were transplanted onto the CAM of a developing chick embryo and anti-HMGB1 antibodies were applied. Anti-HMGB1 antibodies are immunoreactive with blood vessels in the CAM as well as with stromal and epithelial cells (Figure 5.5A and B). Administration of anti-HMGB1 antibodies resulted in a marked reduction of blood vessel density induced by the tumor cells (Figure 5.5C-F). These data point to an important role for HMGB1 in tumor angiogenesis, and its potential as target for therapeutic inhibition of tumor angiogenesis. 


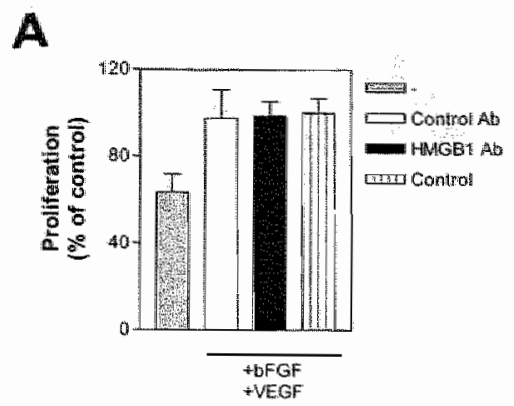

B

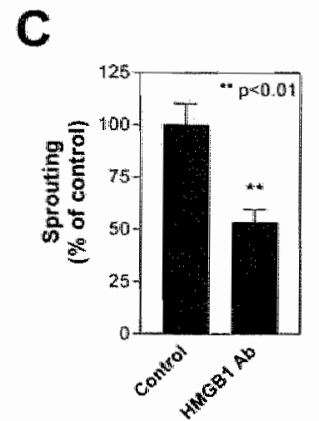

D

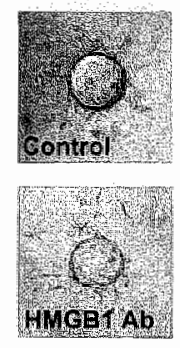

E

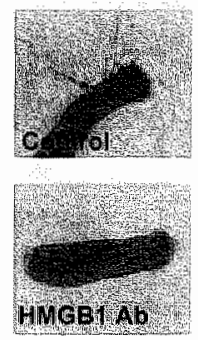

Figure 5.4: Inhibition of : endothelial migration and sprouting by antlHMGBI antibodies.

A) Growth factor induced proliferation of HUVEC is not affected by the presence of 10 ugm anti-HMGB1 antibodies in the culture medium. B) Migration of HUVEC into a wounded area is inhibited by the presence of antiHMGB1 antibodies

$(10 \mu g / m) \quad$ C. D) Sprouting of BCE embedded in a $3 \mathrm{D}$ collagen matrix is inhibited by the presence of antiHMGB1 antibodies $(10 \mu \mathrm{g} / \mathrm{m}$ l) $)(\mathrm{C})$. Both the number of sprouts formed and the distance they extend from the cell-covered beads is inhibited by the presence of the antibodies (D). E) Growth factor induced endothelial sprout formation of tumor vessels ex vivo is inhibited by anti-HMGB 1 antibodies.

\section{> Discussion}

We previously identified HMGB1 as overexpressed in TEC [1]. Here we document the role of HMGB1 in different aspects of angiogenesis and demonstrate a predominant role for the protein in migration and sprouting of EC.

HMGB1 is a player in several feedback loops, both positive and negative, upon interaction with its receptor RAGE. HMGB1 mediated RAGE activation results in increased RAGE expression, thereby amplifying RAGE related signaling events [22]. RAGE activation of EC leads to phosphorylation and inactivation of $\|_{\kappa} B$, resulting in nuclear translocation of nuclear factor $\kappa B(N F k B)$, stimulating the production of several cytokines, such as $T N F \alpha_{n}, \angle L 1 \beta$ and $I L-8$, and the upregulation of adhesion molecule expression, including VCAM1, ICAM1 and E-selectin [23,24]. TNF $\alpha$ stimulates secretion of HMGB1 from EC [15]. RAGE activation also results in the activation of CDC42 and Rac, and the phosphorylation of MAPK, ERK1/2, jun N-terminal kinase (JNK) and p38 [24]. Furthermore, membrane-bound HMGB1 can interact with plasminogen and IPA, resulting in the local generation of plasmin which is subsequently involved in breakdown of HMGB1, but also in the activation of MMP2 and 

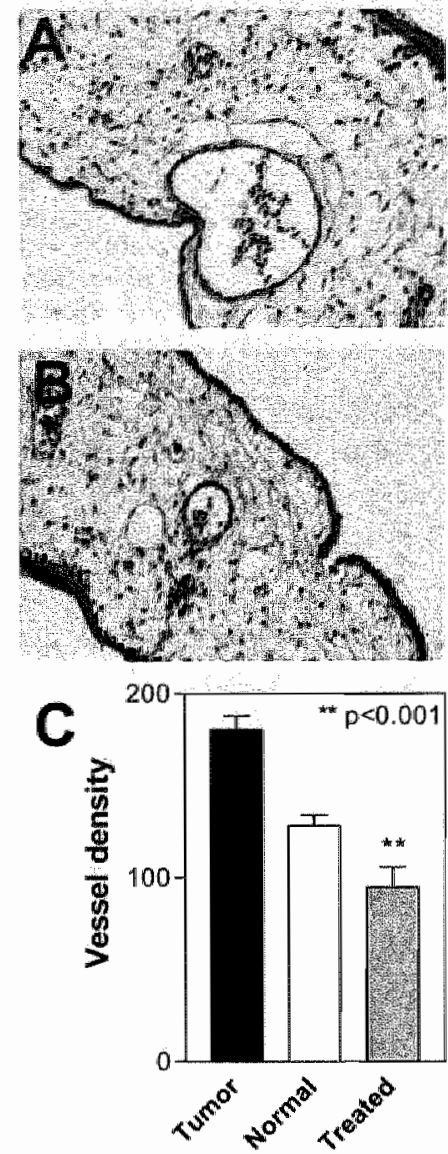
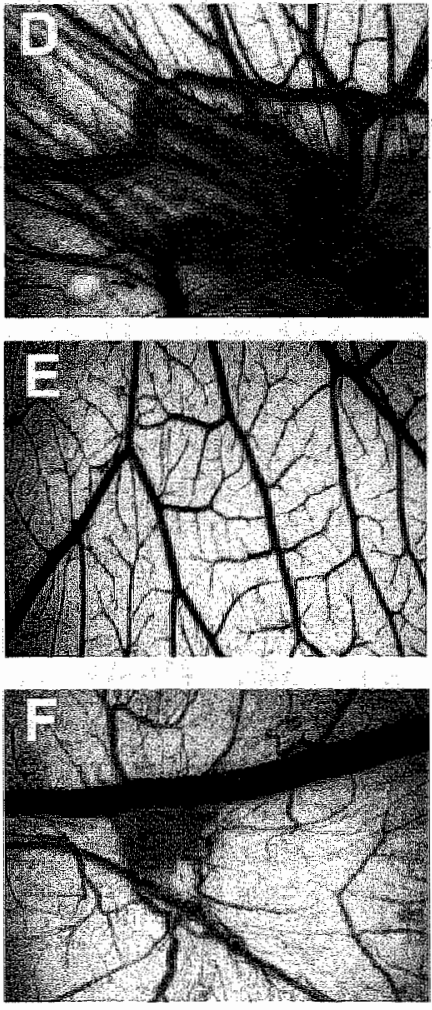

Figure 5.5: Targeting HMGB1 inhibits tumorinduced anglogenesis in vivo.

LS174T tumor cells were transplanted onto the CAM were treated with anti-HMGB1 antibody (10 $\mathrm{\mu g} / \mathrm{ml})$. A-B) HMGB1 antibodies were immunoreactive with the CAMs and stained endothelial cells, but also stromal and epithelial compartments ( $A$, negative control; $B$, anti-HMGB1 antibody). C-F) Treatment with antiHMGB1 antibodies reduced the tumorinduced vessel density (** $\quad p<0.001$ towards tumor and normal) (C). LS174T tumor cells induce increased vascular density and irregular morphollogy (D) as compared to normal untreated CAMs (E). Tumor induced vessel density was reduced by treatrment with antiHMGB1 antibodies (F).

MMP9 [17]. In addition, increased tPA secretion has been shown upon HUVEC stimulation with HMGB1 [24].

Secreted HMGB1 can interact with RAGE. Though we could not directly demonstrate the secretion of HMGB1, we detected the protein in the cytoplasm of EC, which was previously shown to precede externalization [15]. However, HMGB1 lacks a classical secretion signal $[25,26]$. Acetylation of HMGB1 prevents its re-entry to the nucleus resulting in cytoplasmic accumulation [25]. In tumors, necrosis of tumor cells results in the abundant presence of HMGB1 in the microenvironment. Indeed, in addition to endothelial localization, we observed diffuse stromal expression of HMBG1 in colon tumor tissues [1], as well as in diverse colon tumor cell lines.

Activation of RAGE by AGE on endothelial cells increases VEGF production $[27,28]$, though so far, this has not been demonstrated for HMGB1. Recently, it was 
shown that recombinant HMGB1, abeit at high concentrations, could induce ube formation of HUVEC, with its effect approaching that of VEGF [29]. Therefore, secreted HMGB1 might induce upregulation of VEGF via RAGE, which then faciltates endothelial tube formation and migration. Though EC may not be the major contributors of VEGF production in tumors, in vitro effects of HMGB 1 might be caused by increased endothellal VEGF production resulting from HMGB1-RAGE interactions. HMGB1-AS expressing cells indeed falled to respond to activation by bFGF and WEGF. Anti-HMGB1 antibodies however exerted no effect. Stimulation of EC with recombinant HMGB: and subsequent measurement of VEGF MRNA and protein levels in the absence or presence of RAGE blocking antibodies might clarify this issue.

Capillary sprouting of endothelial cells embedded in collagen requires local degradation of matrix components. AGE-RAGE signaling induces MMP expression [18], and membrane-bound HMGB1 can activate MMPs [17]. Furthermore, HMGB1 was detected in the filopodia of migrating neurites [4], suggesting a direct contribution to migration of cells. Taken together, these data suggest a role for HMGB1 in endothellal cell migration. Indeed, anti-HMGB1 antibodies inhibited EC migration and sprout formation and overexpression of HMGB1 increased migration and MMP9 expression of EC. However, whether the expression level of HMGB1 in EC correlates with MMP activity and whether the latter can be modified by exogenous HMGB1 needs to be addressed. The differential effects observed on migration and sprouting of EC as compared to growth factor activation after antibody treatment possibly suggest that these processes are mediated by different actions of HMGB1. HMGB1-mediated sprouting and migration might be regulated by both a RAGE-induced upregulation of VEGF and an induction of MMP activity, whereas a proliferative response might not depend on MMP induction.

In the CAM assay, we observed a significant inhibition of tumor-induced vessel density after treatment with anti-HMGB1 antibodies. However, we cannot exclude a possible additional effect on tumor cell derived HMGB1. Blocking HMGB1-RAGE interactions also inhibited tumor growth and invasion in C6 gliomas, LLC and Ha-ras $+1+$ spontaneous papillomas [10]. Unfortunately, in this report the authors did not address the vascularization of these tumors after treatment, rendering it speculative whether the observed effects were mediated by reduced angiogenesis.

In conclusion, we have demonstrated a role for HMGB1 in different aspects of angiogenesis and that inhibiting HMGB1 results in impaired (tumor) angiogenesis. Though we cannot exclude a possible transcription mediating role of HMGB1, we propose a role for HMGB1 in autocrine and paracrine regulation of VEGF and MMP production in tumor and endothelial cells that contributes to tumor growth and angiogenesis. 


\section{> References}

[11 wan Beînum JR, Dings RPM, wan der Linden E, Zwaans BMM, Ramaekers FCS, Mayo KH, Griffioen AW. Gene expression lumor angiogenesis dissected; specific targeting of tumar endothelium. Submitted.

[2] Yu SS, LIH, Goodwin GH, Johns EW. Interaction of non histone chromosonal proleins HMG1 and HMC2 with DNA. Eur $\mathbb{J}$ Bochem 1977:78 (2):497-502.

[3] Mckinney $K_{i}$ Prwes $C$. Efficient specific DNA binding by p53 requires both its central and $C$-terminal domains as revealed by studies with high-mobility group 1 protein. Mol Cell Bioll 2002;22 (19):6797800.

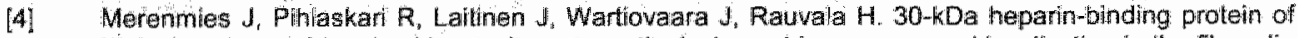
brain (amphoterin) involwed in neurite outgrowth. Amino acid sequence and localization in the flopodia of the advancing plasma membrane. J Biol Chem 1991;266 (25):16722-9.

[5] Wang $H_{1}$ Bloom $O$, Zhang $M$, Vishnubhakat $J M$, Ombrellino $M$, Che J, Frazier $A$, Yang $H$, Ivanova $S$, Borowikova $L$, ef al. HMG-1 as a late mediator of endotoxin lethality in mice. Science $1999 ; 285$ (5425):248-51.

[6] Park JS, Gamboni-Robertson F, He Q. Svetkauskaite D. Kim JY, Strassheim D, Sohn JW, Yamada S. Marwyama I. Banerjee $A_{6}$ et al. High Mobility Group Box 1 protein (HMGB1) interacts with multiple Toll like receptors. Am J Physiol Cell Physiol 2005.

[7] Wautier UL, Schmidt AM. Protein glycation: a firm link to endothelial cell dysfunction. Circ Res 2004:95 (3): $233-8$.

[B] Myint KM, Yamamolo $Y$, Sakurai $S$, Harashima $A$, Watanabe $T, L, H$, Takeuchi $A$, Yoshimura $K$,

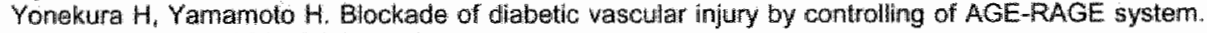
Curr Drug Targets 2005;5 (4):447-52.

[9] Bierhaus $A$. Humpert PM, Morcos M, Wendt $T$, Chavakis $T$, Arnold $B$, Stem DM. Nawroth PP. Understanding RAGE, the receptor for advanced glycation end products. \& Mol Med 2005.

[101 Taguchi A, Blood DC, del Toro G, Canet A, Lee DC, Qu W, Tanji N, Lu $Y$, Lalla E, Fu C, et al. Blockade of RAGE-amphoterin signalling suppresses tumour growth and metastases. Nature 2000:405 (6784):354-60.

[11] Thijssen VL, Brandwijk RJ, Dings RP, Griffioen AW. Angiogenesis gene expression profiling in xenograft models to study cellutar interactions. Exp Cell Res 2004;299 (2):286-93.

[12] van Leeuwen EB, Veenstral $R$, van Wijk $R$, Molema $G$, Hoekstra $A$, Ruiters MH, van der Meer $J$. Characterization of immortalized human umbilical and iliac vein endothelial cell tines after transfection with SV40 large T-antigen. Blood Coagul Fibrinolysis 2000; 11 (1):15-25.

[13] Matveeva OV. Tsodikov AD, Giddings $M$. Freier SM, Wyatt JR, Spiridonov AN, Shabalina SA, Gesteland RF, Atkins JF. Identification of sequence motifs in oligonucleotides whose presence is correlated with antisense activity. Nucleic Acids Res 2000;28 (15):2862-5.

[14] van eter Schaft DW, Dings RP, de Lussanet QG, wan Eijk LI, Nap AW, Beets-Tan RG, Bouma-Ter Steege JC. Wagstaff J Mayo KH. Griffloen AW. The designer anti-angiogenic peptide angimex targets tumor endothellal cells and inhlibits tumor growth in animal models. Faseb J 2002; 16 (14): 1991-3.

[15] Mullins GE, Sunden-Cultberg J, Johansson AS, Rouhiainen A, Erlandsson-Harris $H$, Yang $H$, Tracey $\mathrm{KJ}$. Rauvala $\mathrm{H}$, Palmbled J. Andersson J, et al. Activation of human umbilical vein endothelial cells leads to relocation and release of high-mobility group box chromosomal protein 1. Scand J Immunol 2004:60 (6):566-73.

[16] Fages $C$, Nolo $R_{8}$ Huttunen $H J_{v}$, Eskelinen $E$. Rauwala $H$. Regulation of cell migration by amphoterin. $J$ Cell Sci 2000:113 (Pt 4):611-20.

[17] Parkkinen $\mathrm{J}$, Rauvalia $\mathrm{H}$. Interactions of plasminogen and tissue plasminogen activator (t-PA) with amphoterin. Enhancement of A-PA-catalyzed plasminogen activation by amphoterin. $J$ Biol Chem $1991: 266(25): 16730-5$

[18] Ishiguro $H$, Nakaigawa $N$, Miyoshi $Y$, Fujinami $K$, Kubota $Y$, Uemura $H$. Receptor for advanced glycation end products (RAGE) and its ligand, amphoterin are overexpressed and associalted with prostate cancer development. Prostate 2005;64 (1):92-100

[19] Gleave ME, Monia BP. Antisense therapy for cancer. Nat Rev Cancer 2005;5 (6):468-79.

[20] Shi F, Nomden A, Oberle V. Engberls JB. Hoekstra D. Efficient cationic lipid-mediated delivery af antisense oligonucleotides into eukaryotic cells: down-regulation of the corticotropin-releasing factor receptor. Nucleic Acids. Res 2001:29 (10):2079-87.

[21] Parkkinen J, Raulo E, Merenmies J, Nolo R, Kajander EO, Baumann M, Rauvala H. Amphoterin, the $30-\mathrm{kDa}$ protein in a family of HMG1-type polypeptides. Enhanced expression in transformed cells, leading adge localization, and interactions with plasminogen activation. J Biol Chem 1993;268 (26): 19726-38.

[22] Huttunen $\mathrm{HJ}_{4}$ Rauvala $\mathrm{H}$. Amphoterin as an extracellular regulator of cell motility: from discovery to disease. J Intern Med 2004;255 (3):354-66. 
[23] Treutiger $C J$, Mullins GE, Johansson AS, Rouhiainen A, Rauvala HM, Erlandsson-Harris $H$, Andersson $U$, Yang $\mathrm{H}$, Tracey $\mathrm{KJ}$, Andersson J, et al. High mobility group $1 \mathrm{~B}-\mathrm{box}$ mediates activation of human endothelium. J Intern Med 2003;254 (4):375-85.

[24] Fiuza $C$, Bustin $M$. Tahwar $S$, Tropea $M_{n}$ Gerstenberger E, Shethamer JH, Sufredini AF. Inflammationpromoting activity of HMGB1 on human microvascular endothelial cells. Blood 2003;101 (7):2652-60.

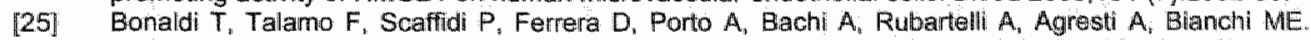
Monocytic cells hyperacetylate chromatin protein HMGB1 to redirect it towards secretion. Embo J $2003 ; 22(20): 5551-60$

[26] Erlandsson Harris $\mathrm{H}_{3}$ Andersson U. Mini-review: The nuclear protein HMGBil as a proinfiammatory mediator. Eur J Immunol 2004:34 (6):1503-12.

[27] Okamoto $T$, Yamagishi S, Inagaki $Y$, Amano $S$, Koga $K$, Abe R, Takeuchi M, Ohno S, Yoshimura A, Makita $Z$. Angiogenesis induced by advanced glycation end products and its prevention by cerivastatin. Faseb ل I 2002;16 (14):1928-30.

[28] Yamagishi $S$, Yonekura $H_{n}$ Yamamoto $Y$, Katsuno $K$, Sato $F$, Mita $I_{\text {, Ooka }} H_{\text {, Satozawa }} N_{\text {, Kawakami }}$ $T$, Nomura $M$, et al. Advanced glycation end products-driven angiogenesis in vitro. Induction of the growth and tube formation of human microvascular endothelial cells through autocrine vascular endothelial growth facior. J Biol Chem 1997;272 (13):8723-30.

[29] Schlueter $C$, Weber $H_{4}$ Meyer B, Rogalla P, Roser $K_{n}$ Hauke $S$, Bullerdiek d. Anglogenetic signaling through hypoxia: HMGB1: an angiogenetic switch molecule. Am J Pathol 2005; 166 (4):1259-63. 


\section{Chapter 6}

\section{Towards high-throughput functional target discovery in angiogenesis research}

Judy R. van Beijnum, Wouter J. Eijgelaar \& Arjan W. Griffioen

Trends Mol Med. 2006 Jan;12(1):44-52. 


\section{$>$ Abstract}

Angiogenesis is a hallmark of malignancies and other proliferative diseases and inhibition of this process is considered to be a promising treatment strategy. Classical gene expression analyses performed in the past decade have generated vast lists of genes associated with disease but have so far yielded only limited novel therapeutic targets for clinical applications. Recently, the focus has shifted from target identification based on gene expression analysis, to identification of genes based on the function of the encoded protein. Disease target genes can now be identified in a high-throughput fashion based on functional properties directly related to the disease phenotype. This new approach significantly shortens the time span for the development of therapeutic applications from the laboratory bench to the hospital bedside. 


\section{> Identification of targets for angiogenesis modulation}

Angiogenesis, the formation of novel blood vessels from pre-existing blood vessels, is a hallmark of numerous pathologies such as cancer, rheumatoid arthritis; endometriosis, atherosclerosis and diabetic retinopathy $[1,2]$. In normal tissues, blood vessels and capillaries are generally in a resting state, maintained by a fine-tuned balance of pro-angiogenic and anti-angiogenic factors present in the microenvironment. However, different stimuli can disturb this balance in favor of proangiogenic factors. These factors activate endothelial cells (EC) that subsequently degrade surrounding matrix components, migrate in the direction of the stimulus, proliferate and form a new capillary. Inhibition of angiogenesis, particularly in cancer, is a promising treatment strategy, and considerable effort has focused on the identification of markers on tumor EC [3-6] that might be targeted for therapeutic intervention. The possibility of using a gene as a target for therapeutic intervention depends on the role of that gene, or the protein it encodes, in a biological mechanism or a disease pathway. To identify gene function, diverse assays can be employed to mimic angiogenesis related processes in vitro such as capillary tube formation in threedimensional matrices (e.g. Matrigel ${ }^{\mathrm{TM}}$ ) or migration of $\mathrm{EC}$ towards a stimulus or into a wounded area [7]. Other assays, such as mouse tumor models or the chick chorioallantoic membrane assay (CAM) can be employed to study gene function in tumor angiogenesis in vivo [8]. From a clinical perspective, targeting a gene product that has a causal relationship with the disease phenotype is probably the most effective therapeutic intervention, because it enables control of the whole biological process.

High-throughput gene expression profiling analysis, boosted by the invention of cDNA microarrays [9] and the publication of the human genome sequence [10], has yielded a vast number of putative disease target genes, but has not yet produced clinically applicable targeted therapeutics. Lists of differentially expressed genes associated with known conditions do not reveal functional information or direct (causative) relevance to a given disease. The characterization and functional validation of these targets in vitro and in pre-clinical models is a time- and labor-intensive process. In addition, a relatively large proportion of these candidate genes will be of limited use because they do not directly contribute to disease development or progression. Thus, strategies are required that distinguish causative and associative changes in gene expression. Recently, the focus has shifted from the identification of disease target genes based on differential expression levels in diseased versus nondiseased tissues, to the identification of candidate target genes based on function, creating a direct link between gene expression levels and phenotype. These novel technologies enable a direct approach for elucidating clinically useful therapeutic targets, thereby reducing time, cost and effort for the development of therapeutics from the laboratory bench to the hospital bedside.

In this review, we highlight techniques used for the validation and functional identification of novel therapeutic targets. First, we discuss validation strategies of 
candidate targets identified by gene expression profiling studies through modulation of protein expression levels and the effect on cellullar properties (from gene to function).

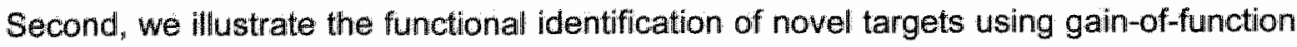
and loss-of-function expression screens (from function to gene), and discuss their applications in angiogenesis research.

\section{Glossiary}

Antisense oligodeoxynucleotide (ODN): A single-stranided, DNA-like molecule of 17-22 nucleotides in length that is complementary to its target mRNA and blocks protein transiation by forming DNA-RNA duplexes.

Array: $A$ systematically arranged repertaire of $D N A$ cells or tissues. These arrays can be amanged in microtiter plates, or printed on glass slides or chips (microarray).

CDNA library: A collection of CDNA. sequences in separate vectors.

Expression library: A collection of CDNA sequences incorporated in expression vectors for expression of transgenes in target cells.

Expression profiling: the study of expression levels of genes or proteins in different tissues.

Expression vector (construct): A circular DNA molecule containing a frequently transcribed promoter with a downstream gene to express. It is used to introduce and express a specific gene (transgene) in a target cell.

Functional genomics: The research field that aims to identify the function of genes.

Gain-of-function assay: The identification of gene function by inducing overexpression of the gene in the studied cell type.

Loss-of-function assay: The identification of gene function by inducing knockdown or knockout of the gene in the studied cell type.

Promoter: A DNA sequence that controls transcription of the downstream gene.

Reporter gene: A gene co-expressed on an expression vector that induces an irrelevant but detectable phenotype [e.g. green fluorescent protein (GFP)].

RNA interference (RNAi): The mechanism by which protein expression is specifically inhibited by interference in RNA translation into a protein, using a natural cellular defense mechanism against doublestranded (ds)RNA.

Selection marker: A gene co-expressed on an expression vector that enables successfully transfected cells to be selected out of untransfected cells (e.g. a gene thal encodes a protein that confers resistance to cytostatic agentsi.

shRNA: Small inverted repeats (hairpins) „also known as palindromes (19-29 nucleotides) linked by a loop of 6-9 bases, that can be cleaved by Dicer to form siRNA duplexes, which are then shunted into the RNAi pathway.

sIRNA: A short, double stranded RNA fragnent complementary to a specific target mRNA that induces RNA interference.

Target validation: Demonstration of the rolle of a particular molecular target in a pathogenic or physiologic process.

Transfection/transduction (transient or stable): Introdluction of DNA or RNA into eukaryotic cells. Transfection typlcally irwolves opening transient "holes' or gates in cells to enable the entry of extracellular molecules such as supercoiled plasmid DNA and siRNA. Transfection can be transient (the inserted DNA is lost over several generations) or stable (the inserted DNA is incorporated into the genome and is passed on to daughter cells). If viral particles are used, transfiection is often referred to as transduction.

Transgene: Exogenous gene expressed in a cell from an expression construct 


\section{> Target validation: From gene to function}

Gene and protein expression profiling techniques have been applied to study molecular events in angiogenesis [6]. Differentially expressed molecules might serve as targets for therapeutic intervention. Validating the relevance of a target for therapeutic applications requires the establishment of a causative relationship between protein expression and/or function and the disease phenotype. This can be achieved by either blacking protein function or by modulating protein expression levels. In this review, we describe several techniques to achieve knockout or knockdown of gene expression, of which RNA interference (RNAi) and antisense oligodeoxynucleotides (ODNs) are mast widely used. Alternatively, cDNA expression constructs can be introduced in the cells to achieve either up- or downregulation of the target protein.

\section{RNA interference}

Knockdown of protein expression offers a powerful means for target validation as protein levels can be directly correlated with the phenotype. RNAi is based on the introduction into cells of small, double stranded RNA molecules [small interfering RNAs (siRNAs)] that target the corresponding endogenous mRNA for destruction, thereby downregulating expression levels of the encoded protein (Figure 6.1A) [11-13]. The exploitation of RNAi has revolutionized functional genomics research, because it is an extremely effective tool for specific gene silencing. siRNAs may be chemically synthesized, produced by expression constructs [14-17] or generated by restriction digestion of long double-stranded RNA molecules produced in vitro (Box 1) [18-21]. This technique is useful for identifying the function of genes in a specific biological process. RNAi has been used extensively to target angiogenic growth factors such as vascular endothelial growth factor (VEGF) and basic fibroblast growth factor (bFGF). In diverse murine models, administration of VEGF siRNAs inhibits tumor growth and angiogenesis [22]. In addition, siRNAs can be targeted selectively to different VEGF splice variants and isoforms $[22,23]$. EC transformed by bFGF overexpress polymerase $\delta$ p12 subunit ( $\mathrm{p} 12$ ) in a gene expression survey [24]. Subsequent knackdown of $p 12$ by RNAi abrogates bFGF induced proliferation of EC, suggesting an important role for p12 in the response of EC to bFGF [25].

SiRNAs might be directly applicable as therapeutic agents and circumvent the need for the design of small-molecule unhibitors of protein activity. In wivo delivery of silRNAs for therapeutic purposes is still in its infancy, but the potential of this type of therapy has been recognized. However, the uptake of siRNAs in vivo is not always very effective, and thus requires high doses of siRNAs to achieve an acceptable therapeutic effect. In addition, systemic delivery of siRNA is needed for proper therapeutic implementation because many target organs can not be reached by local administration. To increase selectivity and avoid nonspecificity, it is of major importance the siRNAs target only the cells of interest. Recently, siRNAs that target VEGF were conjugated to antibody-protamine fusion proteins for specific delivery into 
tumor cells, resulting in inhibited tumor growth in mice [26]. In this study, nanoparticles displaying the RGD (arginine-glycine-aspartic acid) peptide were used for targetted delivery of siRNAs to tumor neovasculature for the knockdown of VEGF receptor 2 [26]. Both tumor growth and anglogenesis were inhibited following intravenous administration of the particles to mice with N2A neuroblastoma tumors [26]. These approaches are promising for the future exploration of various viral and non-viral vector systems for the targeted delivery of siRNA in vivo $[27,28]$.

Thus RNAi is a promising and versatile tool for target validation studies and an upcoming tool for therapeutic intervention. This is further strengthened by the recent advances in systemic, targeted delivery of siRNAs. Major drawbacks of RNAi include the limited success rate of targlet site selection and the high costs of siRNA synthesis; however, several technical advances have partially overcome these limitations (Box 1).

\section{Box 1. RNA interference}

In recent years, an RNA based gene silencing mechanism, originally based on a cellular response to double stranded RINA (dSRNA) derived from replicating viruses or integrated transposons, has been elucidated. These long intracellular ISRNAs are transformed into short dSR/NAs called short interfering RNAs (siRNAs) by the activation of a family member of RNase III ribonucleases termed Dicer. The siRNAs are incorporated into the RINA-induced silencing complex (RISC), which recognizes and degrades the homologous target $m R N A$, preventing protein transilation [11-13].

RNAi in its current applications is based on the introduction of exogenous chemically synthesized SIRNAS of $18-22 n t$ in length to achieve knockdown of the target protein for functional studies. The problem is the design of the siRNA sequences, which depends on published sequence information. Only approximately one in four SiRNAs effectively silences gene expression. siRNA transfection is transient, lasting 3-7 days, depending on the rate of cell division and intracellular degradation; therefore, it is a useful tool onlly in assays based on short periods of incubation. However, for analysis of long-term effects of silencing (e.g. In cell differentiation assays or when studying proteins with a low turnover rate) a more sustained silencing response is needed. To overcome these limitations, expression vectors have been created that can be stably transfected in cells to drive transcription of small hairpin RNA (shRNA) molecules [14,16], or complementary $49-21$ nucleotides RNA sequences $[15,17]$ that have almost the same properties as classic siRNAs. Vector modifications can include the addition of tissue-specific promoters [57], letON-tetOFF systems [58,59], and Cre-loxP regulation [60] to further improve tissue specificity and regulation of target protein expression levels.

Because the design of the siRNAs is crucial for success, methods that render in sifico predictions af the targeted sequences superfluous have been pursued extensively. Alternative methods, based on restriction enzyme digestion of double stranded DNA [e.g. restriction enzyme-generated siRNA (REGS) [19] and SIRNA production by enzymatic engineering of DNA (SPEED)] [18] or RNA [e.g. endonuclease prepared SIRNA (esiRNA) $[20,21]$ have been described recently. These techniques enable efficient generation of SIRNAs that cover the complete target mRNA, but have the intrinsic risk of targeting homologous, nontarget sequences resulting in unwanted side effects. 


\section{Antisense oligonucleotides}

An alternative to RNAi-mediated downregulation of protein expression is the use of antisense ODNs which are small single-stranded, DNA-like molecules (Bo* 2). Binding of antisense ODNs to their complementary target mRNA results in inhibition of protein

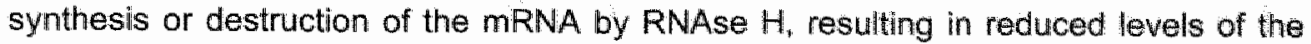
target protein (Figure 6.1B) [29].

The high level of expression of VEGF in many types of tumors and other vascular abnormalities has made it a frequently exploited target for anti-angiogenic therapy. Microarray analysis of VEGF treated EC [30] shows that Down syndrome candidate region 1 (DSCR1) is induced within 30 minutes after exposure to VEGF. DSCR1 was subsequently downregulated in EC using antisense ODNs to examine the effects in diverse angiogenesis assays [31]. The antisense ODN inhibited VEGF-induced transwell migration of HUVEC, which suggests a role for DSCR1 in migration. In a recent study, an orthotopic transplantation model of pancreatic cancer was used to study the effect of VEGF inhibition by an antisense ODN [32]; this inhibition increased survival and reduced tumor growth and microvessel density [32].

\section{Box 2. Antisense oligodeoxynucleotides}

Antisense oligadeoxynucleotides (ODNs) are small, single-stranded DNA-like molecules. The application of these antisense molecules for inhibition of gene expression has been explared since the mid$1980 \mathrm{~s}$, but the advent of siRNA technology has partially overshadowed it. Antisense ODNs bind to the complementary target mRNA, creating a DNA-RNA hybrid. The working mechanism of antisense ODNs to inhibit protein translation is mediated by: (i) triggering RNase H; (ii) interfering with splicing; (iii) blocking the sequences needed for translation by ribosomes; or (iv) inhibiting the ribosome itself [33]. Similar to siRNAs, the knockdown efficiency and specificity are dependent on the design of the ODN, but several software packages and guidelines are available; these rely on algorithms that predict secondary and tertiary structures of RNA or on identifying particular ODN sequence motifs of proven efficacy [61,62]. Different alligonucleotide analogs and chemical modifications aim to improve stability, affinity and recrultment of RNAse $H$, and to reduce of toxicity. Frequently used ODNs are phosphorothioate ODNs [63], peptide nucleid acid (PNA) [64], locked nucleic acid (LNA) [65] and morpholinos [66]. They differ somewhat in their mode of action, ability to recruit RNAse $H_{1}$ and efficiency of intracellular delivery [29,33].

Although the use of ODNs represents a versatile tool in gene expression research, there are general limitations to the application of this technology. Being charged molecules, ODNs are not readily absorbed in many cell types and are prone to endonuclease and exonuclease digestion. ODNs enter cells primarily via endocytosis but can become trapped in the endosomallysosomal compartment. Chemical modiffications of the ODNs, the use of classical transfection reagents or the use of specific carrier molecules might overcome these limitations [29]. Another general drawback associated with the use of antisense ODNs is that their effect is transient. These characteristics should be considered carefully when designing target validation experiments using antisense ODNs. 
In addition to being a valuable tool in target validation studies, antisense ODNs have also entered clinical trials as therapeutic agents for the treatment of diverse conditions and were shown to efficiently suppress target gene expression [33]. From a clinical point of view, the efficient uptake of antisense ODNs by EC might favor these molecules over siRNAs for therapeutic protein knockdown.

\section{Expression constructs}

A straightforward route for studying gene function is to upregulate or overexpress of a gene using expression constructs and to screen for phenotypic changes (Box 3 ). The mRNA of interest is first cloned in an expression vector and is then introduced into the cells to induce expression of the target protein (Figure 6.1C). Numerous different modifications of these vectors are possible, enabling customization of this technique to almost every experimental setup. However, various cell types such as hematopoietic cells or primary cells (including EC) are very difficult to transfect [34-36]; to overcome this limitation, viral vectors are used to transfect these cells $[37,38]$.

Gene expression analysis of EC derived from invasive breast carcinoma showed that HEYL, a transcriptional mediator of Notch signaling [39], is upregulated compared with HEYL in EC isolated from normal breast tissues [4]. To functionally validate HEYL, EC were transduced with adenoviral vectors expressing HEYL and assayed for different aspects of the angiogenesis process such as proliferation, migration, tube formation and apoptosis. Proliferation, but not migration or tube formation, was stimulated by overexpression of HEYL. Also, HEYL protected against apoptosis in serum-starved cells [4].

\section{Box 3. Expression vectors as tools in functional genomics}

Increased axpression of a target protein (gain-of-function) can be achieved by introduction of expression cassettes that are incorporated into vectors and contain the target gene open reading frame preceded by a promoter known to be activaly transcribed in the studied cell type. The same strategy can be axploited for loss-of-finction studies (e.g. by transcription of vector encoded ShRNA or antisense CDNA that can interact with the target MRNA to prevent protein translation, resulting in ireduced protein levels). Expression systems can be customized according to the users" definitions, but commercially available vectors aiready cover a wide range of possibilities. Depending on the aims of the study, systems that differ in, for example, the type of promoter sequences, the presence of reporter genes or selection markers, the efficiency and mode of transfer into cells or the presence of regulatory sequences that enable modulation of expression level are awaillable. Various cell types, sich as hematopoietic cells or primary cells are difficult to transfect by conventional methods strch as electroporation or the use of cationic lipids, although some progress has been made [34-36]. The use of viral vectors (e.g. lentivirus, adenowiruis or retrowirus) provides an alternative to traditional methods because these thave a higher transduction efficiency $[37,38]$. In addition to functional analysis of putative target proteins, expression constructs can be incorporated into warious delivery vehicles tor application in gene therapy. 
The use of expression constructs in cells is a relatively straightforward approach to study phenotypic changes induced by increased expression of the target protein. In addition to functional analysis of putative target proteins, expression constructs can be incorporated in various delivery vehicles for application in gene therapy.

Gene expression profiling studies have identified numerous genes that are associated with angiogenesis in vitro and in vivo, but these genes can only be fully exploited for therapeutic benefit if there is a causal relationship between the expression of the encoded protein and angiogenic properties of EC. Different tools are available to study the function of a particular protein and to validate its potential usefulness as a therapeutic target. Both overexpression of a protein driven by expression vectors and knockdown of protein expression by antisense ODNs or RNAi offer the opportunity to determine the effect of altered protein expression on cell phenotype whereby protein function can be deduced. However, alterations of the expression levels of a target gene may not always lead to a change in phenotype because of functional redundancy in signaling mechanisms. In addition, when transfection efficiency is limited, the induced phenotype change in individual cells might be obscured by the phenotype of background of untransfected cells.
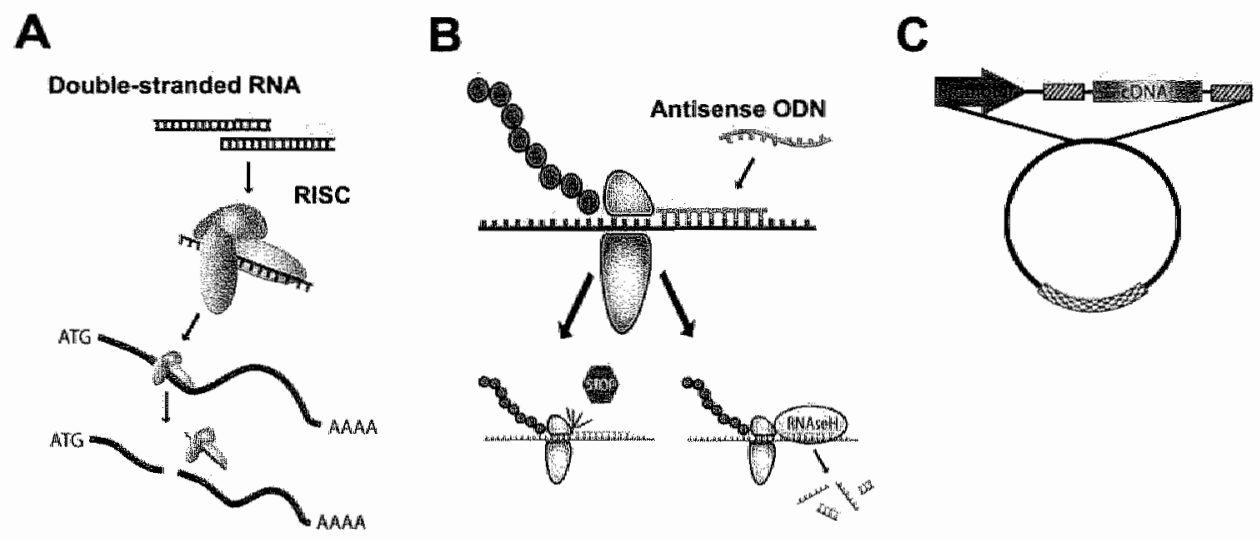

Figure 6.1: Classical target validation techniques.

A) RNA interference. Double-stranded RNA molecules are incorporated in the RNA induced sillencer complex (RISC) forming an active siRNA complex. This complex recognizes the complementary target mRNA that is subsequently cleaved, resulting in downregulated mRNA levels. B) Antisense oligodeoxynucleotides (ODNs). Antisense ODNs base-pair with their complementary target mRNA and can subsequently block the ribosome or induce mRNA degradation by RNAse $\mathrm{H}$, resulting in inhibition of protein synthesis. C) CDNA expression vectors. Expression cassettes containing the CDNA of interest (shaded box) is optionally flanked by sequences that facilitate the localization or detection of the encoded protein (striped boxes). Under the control of a promoter sequence these cassettes can be introduced in target cells to express the CDNA, causing overexpression of the encoded protein. Additionally, transfected cells can be selected for using vector-encoded antibiotic resistance proteins or fluorescent proteins (checkered box). 


\section{> Functional target discovery: From function to gene}

The wealth of gene expression data generated to date has presented the scientific community with the formidable challenge of functionally annotating the individual genes in a multitude of processes and diseases. Recently, diverse high-throughput methods have been shown to functionally annotate putative target molecules, overcoming these limitations. Advances in gene library generation, transfection methods, miniaturization of assays and screening techniques have provided the opportunity for target validation to keep up with the pace of target identification at a genomics scale. In addition, it is now feasible to perform genome-scale screens directly for phenotypic properties. thereby shifting focus from target identification based on expression patterns to function based target discovery. Here, we describe and discuss high-throughput methods that aim to identify candidate target genes based on the cellular phenotypes they induice. These approaches screen for functional properties induced by altering the expression levels of target proteins and therefore require no prior knowledge of the encoding sequence. Thus, genes having a causal role rather than an associative role in a particular disease can be identified directly.

\section{High-throughput library screening}

Transfection of cells with conventional expression constructs can be miniaturized to enable high-throughput, parallel assessment of the consequences of transgene expression. Arrayed expression libraries present a powerful, high-throughput tool for the analysis of gene function on a genome-wide scale using cell-based functional assays. Individually arrayed expression constructs are used for parallel transfections of cells in microtiter plates (Figure 6.2A). The arrayed format enables screening of the library in various cell assays for the expressed sequences that induce a particular phenotype, providing a direct linkage between phenotype and gene expression. Target cells can be directly transfected with the expression constructs and assayed for phenotypic properties (Figure 6.2B). Alternatively, transfection of non-target cells, resulting in the induction of secreted factors, and the subsequent transfer of conditioned medium to the target cell can be used to screen for biological effects of the secreted factor (Figure 6.2C).

Pro-angiogenic factors are secreted proteins that can act in a paracrine or autocrine fashion. To identify novel secreted pro-angiogenic factors, HeLa cells were first infected with adenoviral expression vectors, and conditioned medium of these cells was then transferred to HUVEC embedded in collagen. Capillary tube formation of HUVEC induced by the secreted factors present the conditioned medium was measured to determine possible pro-angiogenic effects [40]. Three different genes were reported to induce capillary tube formation: a truncated variant of VEGF, an inflammatory/transcription activator (CYR61) and an interferon-regulatory factor [40]. In a similar experiment, proliferation of EC mediated by secreted proteins was measured and a previously unknown factor as potent as VEGF was identified 
(http://www.xantos.de/index.php?page=Cancer). These findings illustrate the potential of using large-scale screens to assign functional clues to as unknown genes or assign novel functions to known genes. A general drawback of screening libraries for secreted factors with predefined activities is the predicted low hit rate. Only a minor proportion of the genes present in the transfected libraries encode secreted proteins and only a limited number of these will mediate the desired effect. In a similar way, libraries that express siRNA constructs can be used for lass-of-function screens [41] (http://www.galadeno.com/technology/sima.html; http://www.xantos.de/index.php?page=cDNA+Screening+Tools).

Expression library screening generates a wealth of functional data in an unbiased manner without a priori known sequence information and enables the identification of putative therapeutic targets based on the effect of alteration of the target protein level. New modulators of angiogenesis that might be targets in a therapeutic setting have been identified. In contrast to cell microarrays (described below), assays based on tissue culture in wells are compatible with both adherent cells and cells that grow in

A

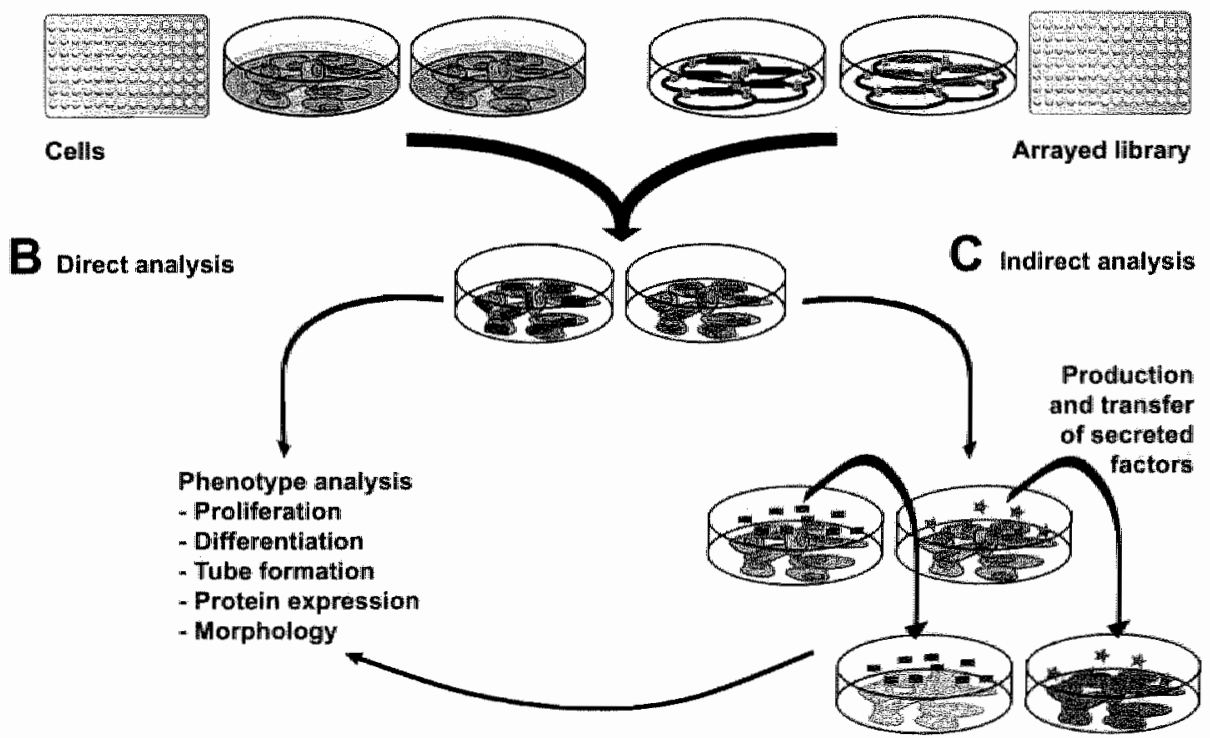

Figure 6.2: Arrayed expression library screening.

A) Expression constructs are arrayed to individual wells of microtiter plates (arrayed library) and used for parallel transfection of cells in individual wells. B) Transfected cells can be directly subjected to phenotype analysis (e.g. to assess proliferation), linking the expressed sequence to the observed functional properties of the cells. C) Alternatively, transfected cells can produce soluble, secreted factors (stars and boxes) that might act in a paracrine fashion on other cells. The conditioned medium of the transfected cells, containing these factors, is applied to other cells that are subsequently screened for changes in phenotype as described. 
suspension. Key to success using this library screening technique is the design of cellbased assays and data acquisition methods that are compatible with its highthroughput nature.

\section{Transfected cell arrays}

Further miniaturization of gene function analysis has become possible by the development of transfected cell arrays or cell (micro)arrays [42-47]. This technique is a promising new application that combines the high throughput of arrayed nucleic acid on glass slides and the functional readouts of cell-based assays. Oligonucleotides or expression libraries are printed, together with a transfection reagent, on glass slides. Cells are plated on the transfection layer, incorporate the DNA or RNA (referred to as reverse transfection), creating localized spots of transfected cells in a layer of untransfected cells. Genes whose expression induces the cellular phenotype of interest can then be identified (Figure 6.3A). After transfection any phenotype analysis that is compatible with the small amount of cells growing on a glass slide can be performed. Using this technology, genes involved in apoptosis induction, cell adhesion and tyrosine kinase signaling [43], proteasome function [46] and NFKB signaling [44] were identified. However, the small amounts of nucleic acid that are reverse transfected pose some technical challenges. Transfection efficiency has to be relatively high to achieve a significant knockdown that will enable phenotypic differences to be detected in a background of untransfected cells. In addition, cell adhesion has to be maintained and the spread of the nucleic acid-lipid complexes has to be restricted. The advantage of a miniaturized microarray format compared with microtiter plate-based techniques is particularly pronounced for cells that originate from limiting sources, such as primary cells. However, primary cells are hard to transfect and difficult to handle. The same limitations also apply to other cell types (e.g. EC). Overcoming these technical challenges would provide new opportunities in angiogenesis research, where (primary) EC are frequently used. Recently, Yoshikawa et al. [45] developed an optimized protocol for efficient on-chip siRNA transfection of mesenchymal stem cells, suggesting that transfected cell arrays will become a more widely applicable tool.

Both gain-of-function assays using conventional expression vectors and loss-offunction assays using small-hairpin RNA (shRNA) expression vectors can be performed. However, this technology is limited to adherent cells and two-dimensional growth, and assays are restricted to relatively static features. For example, capillary tube formation of $E C$ requires the presence of a three-dimensional matrix, which might prove difficult to adapt to this platform. Similarly, assaying migration of EC is not compatible with the array technology because readout relies on strictly localized transfected cells on the slide. However, this array technology can identify genes that, for example, induce proliferation or apoptosis in EC, or mediate the effect of antiangiogenic compounds, thereby providing insight in basic EC biology and putative therapeutic targets. 
A

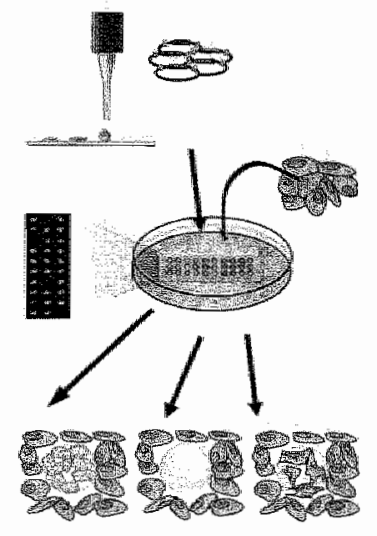

B

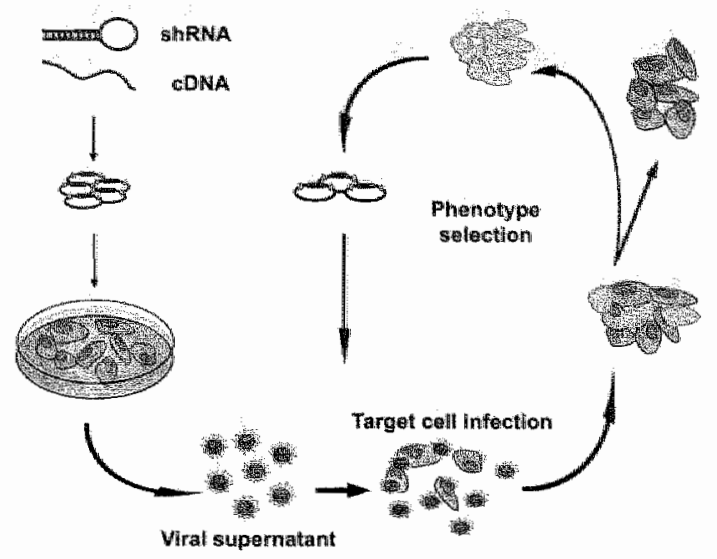

Figure 6.3: Functional target identification.

A) Transfected cell arrays. Nucleic acids are mixed with transfection reagents and spotted on glass slides to create the arrays. Cells are then seeded on the glass slides in cell-culture dishes. By reverse transfection, cells growing on top of a spot take up the nucleic acid. This creates an array of transfected cells within a background of untransfected cells. Finally, the effect of the internalized expression vector on the cell phenotype is measured [e.g. by detection of specific molecules (left), by assessing cell viability (middle) or by monitoring cell morphology (right)]. B) Genetic screens. High-complexity expression libraries (either cDNA for gain-of-function screens or shRNA for loss-of-function screens), usually of viral nature, are introduced into a population of cells. A selection procedure is applied to retrieve those cells from the population in which the expression construct induces the phenotype of interest. The responsible sequence can be retrieved from the selected cells. Subsequent selection rounds using the sequences retrieved from the first round can increase stringency and reduce the identification of false-positives.

\section{Genetic screens}

In genetic screens, complex expression libraries are introduced in a pool of cells that is then screened for individual cDNAs that confer a selectable phenotype. Cells that exhibit the trait of interest are thereby separated from the pool of cells and the inserted CDNA responsible is subsequently retrieved (Figure 6.3B). Selection can be based on, for example, cell survival, compound resistance, reporter gene expression or induction of particular proteins. The power of this approach lies in its unbiased nature because only genes directly relevant to the phenotype under study are selected and identified, providing immediate functional information. One major drawback of this approach is that induction or knockdown of a protein resulting in a lethal phenotype can not be selected. To identify genes that rescue EC from p53 mediated growth arrest, a retroviral CDNA library was introduced in Large-T endotheliall cells (LTEC) that express the temperature sensitive large- $T$ antigen (tsLT). These cells proliferate when grown at $32^{\circ} \mathrm{C}$, owing to the binding to and inactivation of $\mathrm{pRB}$ and $\mathrm{p} 53$ by tsLT. At $39^{\circ} \mathrm{C}$, tsLT becomes inactive and releases $\mathrm{pRB}$ and $\mathrm{p} 53$, and the cells enter growth arrest. Only those gene products that circumvent this p53 action permit cell growth at $39^{\circ} \mathrm{C}$, thus 
enabling selection of these cells. A novel low-density lipoprotein (LDL) receptor and a Ras-like GTPase are responsible for rescuing cellular growth arrest in LTEC. Overexpression of this Ras-like GTPase induces capillary tube formation in Matrigel ${ }^{\text {Th }}$ in vifro in HMEC and in vivo in mice, but its precise mechanism is unknown [48]. The development of siRNA expression vectors enables loss-of-function screening, using the same format as the gain-of-function assays.

Candidate gene identification directly based on function significantly reduces efforts relating to its validation as a putative therapeutic target and clinical development. Moreover, these approaches do not need sequence information a priori and are therefore relatively unbiased. Depending on the resources available, the choice can be made between screening individual genes in a well-based or array platform and applying genetic screens to functionally identify genes of interest. The highly parallel nature of library screening in microtiter plates and transfected cell arrays is advantageous because some genes may be involved in one process but not in another. Such genes may be missed in genetic screens when sequentially different phenotypic manifestations are selected. Recent advances in high content image analysis $[49,50]$ facilitate phenotypic analyses to be performed at a genome-wide scale, and will positively impact both the quantity and the quality of the data generated by these high-throughput applications.

\section{> Functional genomics in angiogenesis research}

Recent advances in high-throughput functional genomics will have a major impact on our future understanding of both pathological and physiological angiogenesis. This shift in focus towards functional identification of putative therapeutic targets enables more efficient clinical translation. Most techniques described in this review rely on efficient transfection of cells. This can be a complicating factor when studying some cell types, such as EC. Recent developments in high-throughput electroporation [51], more efficient methods of transfection of primary (endothelial) cells $[34,35]$, the use of viral vectors $[38,52,53]$, and extensive optimizations for reverse transfection $[45,54]$ might help to overcome these limitations. High-throughput assays for EC migration $[55,56]$ and capillary tube formation [40] meet the requirements for relevant angiogenesis assays and enable the identification of mediators of these processes in arrayed settings. By contrast, genetic screens focus more on cell viability or induction of specific surface proteins whereby cells can be selected for further characterization of the gene of interest. 


\section{$>$ Concluding remarks}

Functional validation tools, originally developed for the analysis of individual genes, have become useful for high-throughput functional identification with almost no limitations. In conclusion, the use of high-throughput gene expression analysis, which merely generates associative data rather than causative data, is being caught up by novel methods that enable direct functional linkage between the gene expression level and the phenotype. Although technical challenges remain, recent progresses have been made in the generation of libraries, and high-content data analysis will enable a broader scientific community to use these tools and to generate a more complete understanding of cellular processes and associated gene expression changes in a wide range of cell systems and diseases (Box 4).

\section{Box 4. Outstanding questions:}

- Will functional larget discovery prove superior to classical target identification by gene expression profiling?

- What (combination of assays should be used preferably to functionally dentify modulators of angiogenesis?

- How can we miniaurize assays but retain their relevance to the in wivo angiogenesis process?

- How can we overcome limitations associated with the low transfection efficiency of EC to enabla more efficient functionall identification of tumor endothelial cell targets?

- How can we integrate the wealth of functional data generated by high-throughput methods and translate this into the development of novel angiogenesis inhibiting therapeutics?

- How can we further streamline the process from functional target discovery to clinical use?

\section{> Acknowledgements}

This work was supported by a grant from the Research Institute for Growth and Development (GROW), Maastricht University. The study has been financially supported by the sixth EU Framework Programme (Integrated Project 'Angiotargeting: contract No. 504743) in the area of 'Life sciences, genomics and biotechnology for health:. 


\section{>> References}

[1] Griffoen AW: Molema $G$. Anglogenesis: potentials for phamacologic intervention in the treatment of cancer, cardiowascular diseases, and chronic inflammation. Pharmacol Rev 2000;52 (2):237-68.

[2] Folkman J. Tumor angiogenesis. In: Holland JF FEl, Basi RC Jr. Kufe DW, Pollock RE Weichselbaum RR, editor. Cancer Medicine, 5th Edition. Ontario. Canada: B.C. Decker linc, 2000. pp. $132-52$

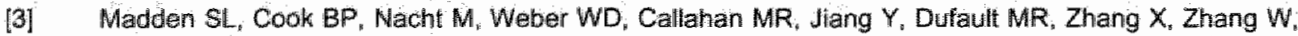
Walter-Yotrling $d$, et. al. Vascular gene expression in nonneoplastic ard malignant brain. Am $J$ Pathol 2004:165 (2):601-8.

(4) Parker BS, Argani P, Cook BP, Liangfeng $H$, Chartiand SD, Zhang M, Saha S, Bardelli $A$, Jiang $Y$, St Martin TB, et al. Alterations in vascular gene expression in invasive breasit carcinoma. Cancer Res $2004,64(21): 7857-66$.

[5] St Crox B, Rago C, Velculescu $V$, Traverso $G$. Romans KE, Montgomery $E_{*}$ Lal A Riggins GJ, Lengauer $C_{\text {i }}$ Vogelstein $B$, et al. Genes expressed in human tumor endothelium. Science $2000 ; 289$ (5482):1197-202.

[6] wan Beilnum JR, Griffioen AW. In silloo analysis of angiogenesis associated gene expression identifies angiogenic stage related profiles. Blochim Blophys Acta 2005;1755 (2):121-34.

[7] Auerbach R, Lewis R, Shinners B, Kubai L, Akhtar N, Anglogenesis assays: a critical overview. Clin Chem 2003:49(1):32-40

[8] Hasan J, Shnyder SD, Bibby Ml, Double JA, Bicknel $R$, Jayson $G C$ Quantitative angiogenesis assays in vivo-ma rewiew. Anglogenesis 2004,7 (1):1-16.

[9] Schena $\mathrm{M}_{*}$ Shalon D, Davis RW. Brown PO. Quantitative monitoring of gene expression patterns with a complementary DNA microarray. Science $1995 ; 270(5235): 467-70$.

[10] Venter JC, Adams MD, Myers EW, LI PW, Mural Ru, Sutton GQ, Smith HO, Yandell M, Evans CA, Holt RA, et al. The sequence of the human genome. Science 2001;291 (5507):1304-51.

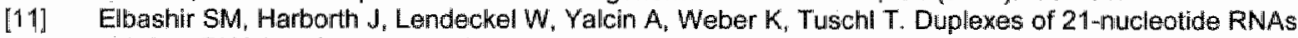
mediate RNA inlerference in ciultured mammalian cells. Nature 2001;411 (6836);494-8.

[12] Fire A, XU S, Mantgomery MK, Kastas SA, Driver SE, Mello CC. Potent and specific genetic interfierence by double-stranded RNA in Caenorhabditis elegans. Nature 1998;391 (6669):806-11.

[13] Plasterik RH. RNA silencing: the genome's immune system. Science 2002;295 (5571):1263-5.

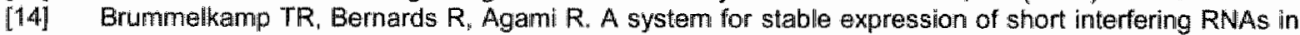
mammalian cells. Science 2002,296 (5567):550-3.

[15] Miyagishi M, Taira K. U6 promater-driven siRNAs with four uridine $3^{\prime}$ overhangs efficiently suppress targeted gene expression in mammalian cells. Nat Biotechnol 2002,20 (5):497-500.

[16] Paddison PJ, Caudy AA, Bernstein E, Hannon GJ, Conklin DS, Short hairpin RNAs (shRNAs) induce sequence-specific silencing in mammalian cells. Genes Dev 2002;16 (8):948-58.

[17] Lee NS, Dohjima T, Bauer G, Li H, Li MJ, Ehsani A, Salvaterra P. Rossi J. Expression of small interfering RNAs targeted aglainst HW- rev transcripts in human colls. Nat Biotechnol 2002;20 (5) $500-5$.

[18] Luo B, Haard AD, Lodish HF. Small interfering RNA production by enzymatic engineering of DNA (SPEED). Proc Nat Acad Sci U S A 2004,101 (15):5494-9.

[19] Sen G, Weliman TS, Myers JW, Blau HM. Restriction enzyme-generated siRIA (REGS) vectors and libraries. Nat Genet $2004 ; 36(2) ; 183-9$.

[20] Yang D, Buchholz $F$, thuang $Z$, Goga $A$, Chen CY, Brodsky FM. Bishop JM. Short RNA duplexes produced by hydrolysis with Escherichia coli RNase III mediale effective RNA interference in manmalian cells. Proc Natl Acad Sci U S A 2002;99 (15):9942-7

[21] Kitter $R$, Putz $G$, Pelletier $L$, Poser I. Heninger AK, Drechisel $D$, Fischer $S$, Konstantinova $I$. Habermann B, Grabner $H$, et al. An endoribonuclease-prepared siRNA scireen in human cells identifies genes essential for cell division. Nature 2004:432 (7020): 1036-40

[22] Lu PY, Xie FY, Woodle MC. Modulation of angiogenesis with siRNA inhibitors for novel therapeutics. Trends Mol Med 2005; 11 (3):104-13.

[23] Chen Z, Varney ML, Backora MW, Cowan K, Solheim JC, Talmadge JE. Singh RK. Down-regulation of vascular endotheliel cell growth factor-C expression using small interfering $R$ NA vectors in mammary tumors inhibits tumor lymphangiogenesis and spontaneous metastasis and enhances survival. Cancer Res 2005:65 (19):9004-11.

[24] Dell'Era $P_{n}$ Coco L. Ronca R, Sennino B, Presta M. Gene expression proflle in fibroblast growth factor 2-transformed endothellal cells. Oncogene 2002;21 (15):2433-40.

[25] Dell'Era P, Nicoli S, Peri G. Niedidu M. Ennas MG, Presta M. FGF2-induced upregulation of DNA polymerase-delta $p 12$ subunit in endothelial cells. Oncogene 2005;24 (6):1117-21. 
[26] Schiffelers RM, Ansari A, Xu J, Zhou Q, Tang Q, Storm G, Molema Q, Lu PY, Scaria PW, Noodle MC. Cancer siRNA therapy by umor selective detivery with ligand-targeted sterically stabilized nanoparticle. Nucleic Acids Res 2004,32 (19):e149.

[27] Lu PY, Xie F. Woodle MC. In wivo appliciation of RNA interference: from functional genomics to therapeutics. Adv Genet 2005:54:117-42.

[28] Sioud M. siRA Delivery in Vivo. Methods Mol Biol 2005; $3092237-50$.

[29] Shi $F$, Hoekstra D. Effective intracellular deliwery of oligonucieotides in order to make sense of antisense. J Control Release 2004;97 (2):189-209.

[30] Abe $M$, Sato $Y$. cDNA microarray analysis of the gene expression profile of VEGF-actiwated human umbilical vein endothelial cells. Angiogenesis 2001;4 (4):289-98.

[31] lizuka $M$, Abe $M$, Shibe $K$, Sasaki I, Sato $Y$. Down syndrome candidate region 1 , downstream target of VEGF, participates in endothelial cell migration and angiogenesis. J Vasc Res 2004:41:44:334-44.

[32] Hotz HG, Hines OJ, Masood R, Hotz $B$, Foitzik T, Buhr HJ, Gill PS, Reber HA, VEGF antisenge therapy inhibits tumor growth and improves survival in experimental pancreatic cancer. Surgery $2005,137(2): 192-9$.

133) Gleave ME, Monia BP. Antisense therapy for cancer. Nat Rev Cancer 2005:5 (6):468-79.

[34] Zaric W, Weltin D, Erbacher $P$. Remy JS, Behr JP, Stephan D. Eftective polyethyleninine-mediatted gene transfer into human endothelial cells. J Gene Med 2004,6 (2);176-84.

[35] Hernandiez $U$, coll T, Ciuldad CJ. A highly efficient electroporation method for the transfection of endothelial cells. Angiogenesis 2004;7 (3):235-41.

[36] Iwersen $N$. Eirkenes B, Torsdalen $K$, Djurowic S. Electroporation by nucleofector is the best nonviral transfection technique in tuman endothellal and smooth muscle cells. Genet Vaccines Theil 2005:3 (1):2.

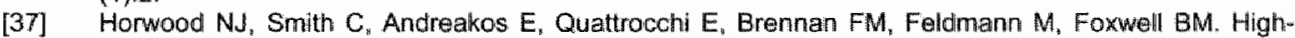
efficiency gene transfer into montransformed cells: utility for studying gene regulation and anallysis of potential therapeutic targets. Arthritis Res 2002;4 Suppli 3:S215-25.

[38] Li M. Rossi J.l. Lentiviral Vector Deliwery of siRNA and shRNA Encoding Genes into Cultured and Primary Hematopoietic Cells. Methods Mol Biol 2005;309:261-72.

[39] Leimeister C, Schumacher N, Steid C, Gessler M. Anallysis of Heyl expression un wilid-type and Notch pathway mutant mouse embryos. Mech Dev 2000;98 (1-2):175-8.

[40] Michiels F, van Es $H$, van Rompaey $L_{n}$ Merchiers $P$, Francken B, Pittois $K$, van der Schueren $J$, Brys $R$, Vandersmissen $J$, Beirinckx $F$, et al. Arrayed adenoviral expression libraries for functional screening. Nat Biotechnol 2002;20 (11):1154-7.

[41] Arts GJ, Langemeijer $E$, Tissingh $R$, Ma L, Pawliska H, Dokic K, Dooiles R, Mesic E, Clasen R. Michiels $F$, et al Adenoviral vectors expressing siRNAs fior discovery and validation of gene function. Genome Res 2003;13 (10):2325-32.

[42] Wheeler DB, Balley SN, Guertin DA, Carpenter AE, Higgins CO, Sabatini DM. RNAi living-cell microarrays for loss-ofmunction screens in Drosophila melanogaster cells. Nat Methods 2004:1 (2): $127-32$.

[43] Zlauddin J, Sabatini DM. Microarrays of cells expressing defined cDNAs. Nature 2001;4111(6833):10710.

[44] Zheng L, Liu J, Batalov S, Zhou Dr Orth A, Ding S, Schultz PG. An approach to genomewide screons of expressed small interfering RNAs in mammalian cells. Proc Natl Acad Sci U S A 2004:101 (1):13540.

[45] Yoshikawa T, Uchimura E, Kishi M, Funeriu DP, Miyake M, Miyake J. Transfection microarray of human mesenchymal stem cells and on-chip siRNA gene knockdown. J Control Release 2004.96 (2) $227-32$

[46] Silva JM, Mizuno H. Brady A, Lucito R, Hannon GJ. RNA interference microarrays: hilgh-throughput loss-of-function genetics in mammalian cells. Proc Natl Aciad Sci U S A 2004;101 (17);6548-52.

[47] Mousses S, Caplen NJ, Cornelison $R$, Weaver D. Basilk M, Hautaniemi S, Elkahloun A.G, Lotufo RA, Choudary $A$, Dougherty ER, et al. RNA microaray analysis in cultured mammalian cells. Genome Res 2003;13 (10):2341-7

[48] Abstracts of the 15th Endothelial Cell Research Symposium. Maastricht, the Netherlands, 23 November 2004. Angiogenesis, 2004. pp. 165-89.

[49] Harada JN, Bower KE, Orth AP, Callaway S, Nelson CG, Larís C, Hogenesch JB, Vogt PK, Chanda SK. Identification of novel mammalian growth regulationy factors by gienome iscale quantltative image analysis. Genome Res 2005:15 (8):1136-44.

[50] Conrad $C$, Erfle $H$, Warnat $P$, Daigle $N$, Lorch $T$, Ellenberg J, Pepperkok R, Eils R. Aultomatic identification of subcellular phenotypes on human cell arrays. Genome Res $2004 ; 14(6): 1130-6$

[51] Clayton J. RNA interference: the silent treatment. Nature 2004;431 (7008),599-605.

[52] Brummelkamp TR, Bemards R, Agami R. Stable suppression of tumorigenicity by virus-mediated RMA. interference. Cancer Cell 2002;2 (3);243-7.

[53] Mizuguchi $H_{1}$. Hayakawa T. Targeted adenovirus vectors. Hum Gene Ther $2004 ; 15(11): 1034-44$. 
[54] Palmer $E$, Freeman T: Cell-based microarraysi current progress, future prospects. Pharmaocgenomics $2005,6(5): 527-34$.

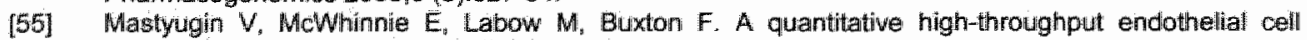
migration assay. J Biomol Sereen 2004;9 $(8): 712 \times 8$.

[56] Yarrow $4 C$, Periman ZE, Mestwood NJ, Mitchison TJ. A high-throughput cell migration assay using scratch wound healing, a comparison of image-based readout methods. BMC Biotechnol 2004,421.

[57] Song $\downarrow$, Pang $S$, Lu Y, Yokoyama KK, Zheng $J Y$, Chiu $R$, Gene silencing in androgen-responsive prostalle cancer cells from the tissue-specific prostate-speciftc antigen promoter. Cancer Res 2004;64 (21):7661-3.

[58] van de Wotering M, Oving I Muncan $V$, Pon Fong MT, Branties H, van Leenen D, Holstege FC, Brummelkamp TR, Agami $R$, Clevers H. Specific inhibition of gene expression using a stably integrated; Inducible small-interfering-RNA wertor: EMBO Rep 2003; 4 (6):609-15.

[59] Matsukura S, Jones PA, Takal D. Establishment of conditional vectors for hairpin siRNA knockdowns. Nucleic Acids Res 2003,31 (15):e77.

[60] Ventura A, Meissner A, Dillon CP. MclManus M, Sharp PA, Van Parijs L, Jaenisch $R$, Jacks $T$. Cre-loxregulated conditional RNA interference from transgenes. Proc Natl Acad Sci U $S$ A 2004;101 (28): $10380-5$

[61] Matveeva OV, Mathews DH. Tsodikov AD, Shaballina SA, Gesteland RF, Atkins JF, Freler SM. Thermodynamic criteria for high hit rate antisense oligonucleotide design. Nucleic Acids Res $2003 ; 31$ (17):4989-94.

[62] Giddings MC, Shah AA, Freier $S$, Alkins JF, Gesteland RF, Matveeva OV. Artificial neural network prediction of antisense oligadeoxynucleotide activity. Nucleic Acids Res 2002;30 (19):4295-304.

[63] Levin AA. A review of the issues in the pharmacokinetics and toxicology of phosphorothioate antisense aligonucleotldes. Biochim Biophys. Acta 1999;1489 (1):69-84.

[64] Ray $A$, Norden $B$. Peptide nuclelc acid (PNA): its medical and biotechnical applications and promise for the future. Fasseb J 2000;14 (9):1041-60.

[65] Jepsen JS, Wengel J. LNA-antisense rivals siRNA for gene silencing. Curr Opin Drug Discov Devel $2004,7(2): 188-94$

[66] Schmajuk $G$, Sierakowska $H$, Kole $\mathbb{R}$. Antisense oligonucleotides with different backbones... Modification of splicing pathways and efficacy of uptake. J Biol Chem 1999;274 (31):21783-9. 


\section{Chapter 7}

\section{General discussion}




\section{> Gene expression in endothelial cells}

The inhibition of new vessel formation in tumors and the destruction of existing tumor vasculature is thought to present a powerful means of cancer treatment. A thorough understanding of the functional and phenotypic characteristics of tumor endotheliall cells is pivotal to designing novel therapeutics.

In this thesis we describe the identification of candidate target genes for angiostatic tumor therapy by investigating gene expression changes in tumor endothelium as compared to normal and angiogenic endothelium. It has been recognized that tumor endothelial cells differ from normal, resting endothelial cells, and that these characteristics are highly influenced by microenvironmental clues (chapter 1). The gene expression response of endothelial cells to different angiogenic factors in vitro has been extensively studied. As described in chapter 2 , different growth factors applied to endothelial cells in vitro evoke different gene expression responses. Part of these differences can be intrinsic to the different growth factors applied; other biases may be related to the gene expression profiling platform and particular culture conditions that were used. Nevertheless, the functional signature of growth factor stimulated endothelial cells is indicative of active proliferation and turnover. Similarly, only a limited number of genes is concordantly regulated in different tube formation assays, though a clear functional bias towards adhesion molecules and matrix remodeling proteins is observed. However, the extrapolation of these data to the in vivo situation is limited. Therefore it may be desirable to use endothelial cells isolated directly from the tissues of interest. Based on the expression of specific markers, endothelial cells can be purified by using immunomagnetic or flowcytometric separation techniques [1]. So far, few studies have so far reported on gene expression profiles of endothelial cells isolated from tumor tissues [2-4]. Comparison of upregulated genes in these different tumors revealed a particularly strong bias towards extracellular matrix proteins, especially collagens, though only SPARC was upregulated in all tumor types examined. In conclusion, comparison of in vitro models with the in vivo situation indicates clear differences in gene expression patterns.

We observed similar differences when we compared genes overexpressed in tumor endothelial cells with genes upregulated in activated HUVEC (chapter 3 ), as only 24 transcripts of a total of $265(9 \%)$ were concordantly overexpressed in the two comparisons. It has been shown that endothelial cells isolated from fresh tissues retain their phenotype in culture for some time [5-8] though over time their phenotype may change as a consequence of the altered microenvironment in culture $[9,10]$. Recent work has demonstrated that isolated tumor endothelial cells maintained in culture differed considerably from normal endathelial cells $[11,12]$. Thus, cultured tumor endothelial cells may be considered an alternative source for expression profiling studies, circumventing problems associated with limited material available directly after isolation. We used suppression subtractive hybridization (SSH) to profile gene expression in diverse angiogenic and non-angiogenic endothelial cells. Major strengths 
of SSH are its independence of known sequences and the generation of nonredundant repertoires, enabling the discovery of rare and previously unknown transcripts, for example, certain tissue-specific splice variants. Comparing gene expression in tumor angiogenesis with physiological angiogenesis in the placenta revealed considerable overlap (85/42) referred to as GAG/A transcripts. This is not surprising, since many angiogenic factors play a role in both physiological and pathological angiogenesis. Moreover, it emphasizes the importance of our approach to focus on TAGs, which are genes that are overexpressed in tumor endothellal cells vs. both normal endothelial cells and placenta endothelial cells. This way, the chance of interfering with physiological angiogenesis when targeting a TAG is minimized.

Using our method, we identified SPARC, collagen loc 1 and collagen IVa.1 that have previously been confirmed as tumor endothelial markers in brain, colon and breast tumors by SAGE [2-4]. However, the latter studies used only a very limited number of tumors and normall tissues for their analysis, and therefore have a considerable risk of representing patient-related features rather than general ones. We poolled the RNA of endothelial cells isolated from 5 different individuals, and used normal tissue of the same patients to minimize the introduction of such artifacts. Therefore, we are confident that the TAGs we identified are representative for the endothelium of most colorectal tumors. However, different types of tumors may display different TAGs though some TAGs appear to be pan-tumor endothelium specific - and it would be valuable to further investigate this to enable the development of therapeutics applicable to diverse types of cancer.

\section{> Target validation}

Though gene expression studies provide valuable insights in the biology of the tissue under investigation, they do not discriminate between genes that are causally rellated to the phenotype, i.e. normalization of the changed expression level or biocking the aberrantly expressed protein results in reversal of the phenotype, and genes that are merely changed in expression to meet altered metabolic demands. Because the characterization and functional validation is a time-consuming and laborious process, it is critical to prioritize putative therapeutic targets. Based on gene ontology databases and literature searches, some functional clues about a gene can be elucidated to determine its potential as a therapeutically targetable molecule. For vascular targeting strategies, extracellular locallization of the targeted protein is required, though for classical anti-angiogenic strategies, molecules that function in cell-cycle progression or apoptosis regulation may also be valuable. From the set of 17 TAGs, we chose four genes with a reported extracellular localization: vimentin, CD59, HMGB1, and IGFBP7 (chapter 3). Using antibodies as targeting molecules we tested whether interference with protein function had impact on endothelial cells in vitro as well as in vivo. In chapter 3, we show that antibodies directed at these proteins interfered with tube 
formation of bovine endothelial cells. Furthermore, antibodies directed against HMGB1. CD59 and vimentin also inhibited blood vessel formation in vivo in the CAM assay. This latter model is actually a model for developmental angiogenesis and might not be considered appropriate to investigate tumor angiogenesis. However, different genes playing a role in developmental processes have been shown to be re-expressed during tumorigenesis and tumor angiogenesis [14], e.g. the ED-B domain of fibronectin [15]. In subsequent experiments, colon tumor cells were grown on top of the CAMs to provide a better model and antibodies directed against HMGB1 and vimentin were capable of inhibiting the tumor induced vasculature (chapters 4 and 5). Our findings that antibodies directed against vimentin were capable of inhibiting tumor vascularization and growth provides proof that the molecules we identified might be used for targeting tumor angiogenesis. Furthermore, the observation that anti-vimentin antibodies target to the tumor vasculature provides the opportunity to image the tumor vasculature for diagnosis and/or disease monitoring $[16,17]$, or to deliver therapeutics $[18,19]$.

\section{Vimentin}

The successful inhibition of angiogenesis by targeting vimentin with antibodies was somewhat surprising, as the protein has been extensively documented as an intracellular cytoskeletal protein. However, recent publications have questioned the exclusive intracellular localization of vimentin. In macrophages, secreted vimentin was shown to be actively involved in phagocytosis of bacteria [20]. Vimentin tail domain, detected by antibody clone $\mathrm{V} 9$, was detected on the surface of neutrophils undergoing apoptosis, though at present it is not clear whether the detected vimentin is representative of the total protein or of a caspase generated cleavage fragment [21]. In contrast, on apoptotic T-lymphocytes both the rod and the tail domain of vimentin could be detected on the surface using different antibodies [22]. Furthermore, vimentin was identified as the ligand for SC5 mAb and located on the extracellular side of the plasma membrane of activated normal T-lymphocytes and malignant Sézary syndrome cells [23]. Thus, vimentin expression on the surface of EC might be feasible, and might contribute to tumor angiogenesis.

In chapter 4 we further characterized the function of vimentin in different aspects of angiogenesis. Two different antibodies reactive with vimentin were capable of inhibiting endothelial cell migration and tube formation. This suggests the presence of vimentin on the cell surface or in the extracellular environment, as antibodies added to the culture medium can only interfere with proteins that are accessible from the extracellular space. Surface associated expression was further substantiated by the observations that non-permeabilized cells show immunoreactivity with the vimentin antibodies in flowcytometry and in immunofluorescence studies. This surface associated pool of vimentin appears more dynamic than the total cellular pool of vimentin as it was more abundant in expansively growing cells than in contact-inhibited cells, showed polarization in the direction of migration and was increased after treatment with the phosphatase $2 \mathrm{~A}$ inhibitor okadaic acid. Interestingly, 
epigallocathechin gallate (EGCG), a green tea compound that has proven antiangiogenic activity [24,25], was recently shown to bind vimentin [26]. EGCG can specifically block the phosphorylation of vimentin, via inhibition of CDC2 kinase activity, suggesting that phosphorylation of vimentin plays an important role in angiogenesis. Taken together, we have shown increased vimentin expression on the surface of tumor endothelial cells and demonstrated that interference with vimentin function impairs the angiogenic potential of endothelial cells.

Based on our observations, one might expect severe vascular defects or even embryonic lethality in vim- $/$ - mice. Interestingly, vimentin knockout mice are viable and show no obvious phenotype [27]. Only detailed examination revealed vascular defects [27-29] and impaired wound healing due to delayed migration of fibroblasts [30]. Furthermore, transplantation of vim- $/$ - teratocarcinoma cells in vim $+/+$ recipient mice did not show any differences as compared to vim $+1+$ teratocarcinomas transplanted in $v i m+/+$ mice [31]. Though the endothelial cells of vim-/ recipient mice do not express vimentin, compensatory mechanisms may be responsible for survival and tumor angiogenesis. Whether fibroblasts and other vimentin expressing cells also display vimentin on the cell surface, and whether this may give rise to adverse effects in a therapeutic setting requires further investigation.

It was recently postulated that PAL-E antibody, used for decades to distinguish blood and lymphatic vessels, recognizes a secreted vimentin dimer [32]. This PAL-E reactive protein was immunoprecipitated from HMEC and was recognized by different anti-vimentin antibodies. Hence, we hypothesized that this secreted form of vimentin might be the surface accessible fraction, which we successfully targeted with antivimentin antibodies in a therapeutic anti-angiogenesis setting. Indeed, in vitro migration and tube formation assays in the presence of PAL-E suggested an inhibitory effect of the antibody on the angiogenic properties of EC (data not shown). However, others have argued the antigen reactive with PAL-E antibody to be plasmalemmal vesicle 1 ( $P V-1)$, a homodimeric transmembrane protein associated with caveolae [33]. Transfection of vimentin and PAL-E antigen negative $\mathrm{CHO}$ cells with $\mathrm{PV}-1$ resulted in immunoreactivity with PAL-E. Also, clearance of lysates with V 9 antibody did not reduce $P A L-E$ reactivity, suggesting vimentin is not the antigen recognized by PAL-E. However, both studies lack the final proof of the identity of PAL-E antigen. First of all, V9 should have been used by $X u$ et al. [32] to immunoprecipitate a protein reactive with PAL-E in western blot, to confirm the immunoreactivity of immunoprecipitated PAL-E antigen with anti-vimentin antibodies. Second, downregulation of vimentin and PV-1 expression in PAL-E reactive endothelial cells by using RNA interference should reveal which gene is responsible for PAL-E reactivity. Thirdly, vimentin could be expressed in cells that are not reactive with PAL-E to determine whether it induces reactivity, though cell-type related protein modification factors may not allow PAL-E antigen to form in non microvascular endothelial cells. Our own observations point to a role for PAL-E antigen in EC migration and tube formation similar to that of vimentin, but we can not be conclusive about the identity of the antigen. Thus, whether PAL-E 
targets a post-translationally modified form of vimentin or the human homologue of PV1 (or possibly another protein) is still under debate.

\section{HMGB1}

HMGB1 is another protein that was initially regarded to be expressed intracellularly as a chromatin binding molecule [34], but later was shown to be expressed extracellularly as well $[35,36]$. As described in chapter 5 , antibodies directed against HMCB1 were effective in inhibiting endothelial cell migration and tube formation as well as blood vessel formation in the CAM assay, though we could not directly asses whether it was expressed on the surface of endothellall cells or whether it was secreted. Mullins et al. [37] reported that secretion of HMGB1 is preceded by relocalization of the protein from the nucleus to the cytoplasm after stimulation of endothelial cells with TNF $\alpha$ and LPS. Using immunofluorescence, we observed cytoplasmic staining for HMGB1 in a subset of endothellial cells cultured in vitro, suggesting the protein may be secreted.

HMGB1 exerts its extracellular effects by interacting with the receptor for advanced glyation end products (RAGE) (recently reviewed by Bierhaus et al. [38]). Another ligand for RAGE, AGE, induces VEGF production in endothelial cells $[39,40]$. Hence HMGB1-RAGE signaling may also induce VEGF production, though this has not been proven directly. Though EC may not be the major contributors of VEGF production in tumors, in vitro effects of HMGB1 may be caused by increased VEGF production resulting from HMGB1-RAGE interactions. Stimulation of endothelial cells with recombinant HMGB1 in the presence or absence of RAGE blocking antibodies and measurement of VEGF levels might clarify this issue. Blocking HMGB1-RAGE interactions inhibited tumor growth and invasion in C6 gliomas, LLC and Ha-ras +/+ spontaneous papillomas [41]. Unfortunately, the authors did not address the vascular density of treated tumors to determine whether some of the effects were mediated by angiogenesis inhibition, as we observed a predominant endothelial localization of HMGB1 protein in colon tumors by immunohistochemistry. At this moment, our data and that of others point to a role for HMGB1 in tumor angiogenesis, but whether it will prove to be feasible therapeutic target requires further investigation.

The therapeutic potential of the remainder of the TAGs has not been elucidated yet. Based on the successful targeting of vimentin and HMGB1 in (tumor) angiogenesis in witro as well as in vivo, we are confident that more TAGs will prove at least equally good therapeutic targets. The overexpression of collagens lal and IV 1 on the endothelial cells of other types of cancer [2-4] suggests these molecules might be interesting candidate genes for future investigation. A further challenge lies in the characterization of the genes with as yet an unknown function. It is interesting to note that TAG-38 (HSPC014) has previously been identified as overexpressed in an SSH analysis of colon tumor tissue vs. normal colon tissue [42]. Whether the encoded protein is present on both tumor and endothelial cells, is not known. A search for 
common transcription factors regulating the expression of TAGs by TransFac (http://www.gene-requlation.com/pub/databases.htmittransfac) revealed that of only a few TAGs the transcription factors were known. Hence, no conclusive statement can be made about possible transcription factors that are responsible for the observed gene regulation. Ingenuity pathway analysis (http:/www ingenuity com) revealed that the dominant pathways that TAGs and GAGs are involved in are cancer, invasion of cells, apoptosis of tumor cells, cellular growth and proliferation, and cell movement (Table 7.1). Surprisingly, vimentin is not classified as gene playing a role in cancer and cell movement, though extensive literature is available describing these functions $[30,43-45]$, and the same is true for HMGB1 $[36,46,47]$. Though very useful tools for the analysis of large datasets, such database analysis apparently need to be interpreted with caution as they have their limitations.

Table 7.1: Pathway analysis of TAGs and GAGs

\begin{tabular}{|c|c|c|c|c|}
\hline $\begin{array}{l}\text { Cell growth \& } \\
\text { proliferation }\end{array}$ & Cancer & Cell motility & $\begin{array}{l}\text { Invasion of } \\
\text { tumor cells }\end{array}$ & $\begin{array}{l}\text { Cell death \& } \\
\text { apoptosis }\end{array}$ \\
\hline $\begin{array}{l}\text { AKAP13 } \\
\text { ATP5G1 }\end{array}$ & AKAP13 & & & \\
\hline & & & & CARD8 \\
\hline CAV'1 & CAV1 & CAVII & CAV1 & CAV1 \\
\hline $\mathrm{CCL} 2$ & $\begin{array}{l}\mathrm{CCL} 2 \\
\mathrm{CD} 59\end{array}$ & $\begin{array}{l}\text { CCL2 } \\
\text { CD59 }\end{array}$ & $\mathrm{CCL} 2$ & $\begin{array}{l}\text { CCLL2 } \\
\text { CD59 }\end{array}$ \\
\hline $\begin{array}{l}\text { CD86 } \\
\text { CDK2AP1 }\end{array}$ & CDB6 & CD86 & & \\
\hline COL1A1 & $\operatorname{COL} \mid A \|$ & & & \\
\hline $\begin{array}{l}\text { CTSB } \\
\text { EIF4A1 }\end{array}$ & CTSB & CTSB & CTSB & CTSB \\
\hline FKBP1A & & & & $\begin{array}{l}\text { FKBP1A } \\
\text { FOSL2 }\end{array}$ \\
\hline $\begin{array}{l}\text { HEYL } \\
\text { HNRPC }\end{array}$ & & & & $\begin{array}{l}\text { HEYL } \\
\text { HNRPC }\end{array}$ \\
\hline ICMT & ICMT & HSPCA. & & \\
\hline $\begin{array}{l}\text { lGFBP7 } \\
\text { INSR }\end{array}$ & INSR & & & $\begin{array}{l}\text { GFBP7 } \\
\text { NSSR }\end{array}$ \\
\hline TGB & $\begin{array}{l}\text { ITGB1 } \\
\text { MMP4 }\end{array}$ & $\begin{array}{l}\text { TTGB1 } \\
\text { MMP1 }\end{array}$ & $\begin{array}{l}\text { ITGBY } \\
\text { MIMP1 }\end{array}$ & $\begin{array}{l}\text { ITGB1 } \\
\text { MMP1 }\end{array}$ \\
\hline $\begin{array}{l}\text { MMP3 } \\
\text { PECAM11 } \\
\text { PSMF1 }\end{array}$ & $\begin{array}{l}\text { MMP3 } \\
\text { PECAM1 }\end{array}$ & $\begin{array}{l}\text { MMP3 } \\
\text { PECAM11 }\end{array}$ & MMP3 & $\begin{array}{l}\text { MMP3 } \\
\text { PECAM1 }\end{array}$ \\
\hline RASGRF2 & RRALB & & & \\
\hline & & & & RNASE 1 \\
\hline $\begin{array}{l}\text { SHFM1 } \\
\text { SPARC }\end{array}$ & for & $\begin{array}{l}\text { SPARC } \\
\text { TMSB } 4 X\end{array}$ & $\begin{array}{l}\text { SPARC } \\
\text { VIM }\end{array}$ & SPARC \\
\hline
\end{tabular}




\section{> Technological advances}

The recent development of small interfering RNA molecules for knockdown of protein expression allows studying protein function without using small molecules or antibodies that block the protein directly. This is especially useful when genes are investigated for which no antibodies or small molecule inhibitors are available yet. Generally, the technique requires the introduction of small interfering RNA molecules into the cell, either as duplex RNA molecules or incorporated in vector systems, by transfection. Primary cells, e.g. EC can however be difficult to transfect, resulting in low transgene expression, which may obscure the effects of protein knockdown, and may be difficult to apply in vivo. As described in chapter $6_{*}$ the cumbersome process of target validation following gene expression profiling analysis has resulted in the development of novel high-throughput technologies for functional target validation and identification. Several techniques employing RNA interference or expression vectors are now available to identify candidate target genes based on the cellular phenotype they induce, enabling a more direct approach for identifying clinically useful therapeutic targets and reducing target validation efforts. Implementing such technologies in angiogenesis research could contribute considerably to a more efficient identification of putative therapeutic candidate molecules.

Bearing vascular targeting applications in mind, direct analysis of proteins expressed on tumor endothelial cells poses an alternative to gene expression profiling studies. These approaches may also take into account post-translational modifications of proteins. Peptide- and antibody phage display approaches have yielded some tumor endothelial targets directly accessible from the blood stream $[48,49]$. Recently, direct analysis of endothelial membrane fractions has been used to identify differentially expressed proteins on the luminal surface of tumor endothelial cells using peptide mass-spectrometry $[50,51]$. Major advantages of these proteomics approaches over genomics approaches are the ability to directly focus on extracellularly expressed proteins and to take into account post-translational protein modifications. A drawback of these techniques is unfortunately their currently limited applicability to the human siluation.

\section{$>$ Conclusions and outlook}

We have successfully used SSH to profile changes in gene expression in endothelial cells of different origins in order to identify genes associated specifically with tumor angiagenesis. We identified both known and novell markers of tumor angiogenesis (TAGs). We subsequently assessed the functional contribution of different TAGs to various aspects of angiogenesis in vitro and in vivo. We show that antibody targeting of one of the TAGs, i.e. vimentin, effectively reduces tumor size and tumor vascular density, underscoring the feasibility of our approach. 
Inhibition of angiogenesis is thought to contribute considerably to the treatment of cancer in the near future, though it is envisaged that this will mainly be in combination with other therapeutic modalities, such as chemotherapeutics. Inhibition of new vessel formation can help prevent the outgrowth of metastasis to clinically relevant tumors and prevent renewed growth of tumors that have acquired drug resistance. Clinical medicine will benefit most from truly novel therapeutics that have been rationally designed.

The approval of anti-VEGF antibodies merely illustrates the interest in vascular targeting and angiogenesis inhibition as anticancer strategy, but these drugs rely basically on the same idea as classical chemotherapeutics, i.e. a larger dependence of the diseased cell than the healthy cell on the factor or process being blocked. Hence, side effects of anti-VEGF antibodies as well as other angiogenic growth factor inhibition are imminent. In fact, besides its vascular activity, VEGF is trophic for nerve cells, lung epithelium and cardiac muscle, pointing out that when anti-VEGF therapeutics are overdosed this may give rise to neurodegeneration, respiratory distress and cardiac failure $[52,53]$. The use of anti-VEGF therapeutics should be carefully considered in patients at risk for stroke or other ischaemic heart diseases.

The deprivation of angiogenic growth factors is also prone to the development of drug resistance as tumors may escape the angiogenesis inhibition by shifting to the production of other growth factors. Agents that counteract the endothelial phenotype induced by the presence of the tumor can accomplish a prolonged suppression of angiogenesis. For example, endostatin was shown to downregulate several pathways that are induced during angiogenesis, resetting the activated endothelial cell to a quiescent one [54]. Profiling the response of tumor cells and endothelial cells to anginex revealed a considerable induction of angiopoietin-3/4, TIE1 and TIE2, and a decrease in VEGF-B and VEGF-D expression in non-tumor tissue (vasculature and stroma) [55]. The identification of the endothelial receptors that mediate these effects may further facilitate the development of novel angiogenesis inhibitors.

In conclusion, the identification of molecular targets amenable for interference with tumor endothelial cell function provides a more detailed insight in the molecular regulation of tumor angiogenesis and enables the development of novel diagnostic tools and improved strategies for the treatment of cancer by therapeutic interference in angiogenesis. 


\section{>> References}

11) Hilen $F$, Melotte $W$, wan Beifnum JR, Grifioen AW. Endothellal cell biology. In: Staton CA Lewis $C$.

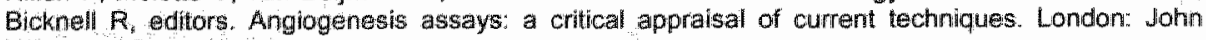
Wiley and soms, in press.

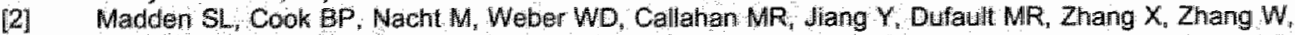
Waller Yohring w. Rouleau $C$ Akmaev VR, Wang $C J$, Cao $X$, Sil Martin TB, Roberts BL, Teicher BA, Kinger KW, Stan RV, Lucey B, Carson-Watter EB, Laterra J, Walter KA. Vascular gene expression in nonineoplastic and malignant brain. Am J Pathoil $2004,165(2), 60 *-8$.

[3] Parker BS, Argani $P$, Cook BP, Liangfeng $H$, Chartrand SD, thang $M$, Salna $S$, Bardell A, Jiang $Y$, St Martin $T B_{3}$, Nacht $M$; Teicher $B A_{*}$ Klinger $K M$, Sukumar $S$, Madden SL. Alterations in vascular gene expression in invasive breast carcinoma. Cancer Res $2004,64,(21), 7857-66$.

[4] St Croix B. Rago C, Velculescu $V$, Traverso G, Romans KE, Montgomery E, Lal A, Riggins Gl, Lengauer $C$, Vogelstein $B$, Kinzler KW. Genes expressed in human tumor endothelium. Science $2000 ; 289(5482): 1197-202$.

[5] Griffioen AW. Phenotype of the tumor vasculature; cell adhesion as a target for tumor therapy. The Cancer Journal 1997; 10 (5):249-55.

[6] Folkman J, Haudenschild CC, Zetter BR. Long-term culture of capillary endothelial cellis. Proc Natl Acad Sci U S A 1979;76 (10):5217-21.

[7] Bussolali $B$, Deambrosis I, Russo $S$, Deregibus MC, Camussi $G$. Altered angiogenesils and survival in human tumor-derived endothellal cells. Faseb i 2003;17 (9):1159-61.

[18] Kalmann BA, Wagner $S$. Hummel V, Buttmann M, Bayas A, Tonin JC, Rieckmann P. Characteristic gene expression profile of primary human cerebral endothelial cells. Faseb J 2002; 16 (6):589-91.

[9] Favre CJ, Mancuso M, Maas $K$, McLean JW, Balluk P. McDonald DM. Expression of genes involvedin vascular development and angiogenesis in endothelial cells of adult lung. Am J Physiol Heart Cinc Physiol $2003,285(5): H 1917-38$.

[10] Oxhorn BC, Hillizel DJ, Buxton IL. Isolation and characterization of large numbers of endothelial cells for studies of cell signaling. Microvesc Res $2002 ; 64(2): 302-15$.

[11] Blan XW, Jiang XF, Chen $J H_{*}$, Bai JS, Daü $C$, Wang $Q L$, Lu JY, Zhao $W, X i n R$, Lilu MY, Shi JQ, Wang $\mathrm{JM}$. Increased angiogenic capabilithes of endothelial cells from microvessels of malignant human gliomas. Int Immunopharmacol $2006 ; 6$ (1):90-9.

[12] Grange C, Bussolati B, Bruno S, Fonsato V. Sapino A. Camussi G. Isollation and characterization of human breast tumor-deriwed endothelihal cells. Oncol Rep 2006;15 (2):381-6.

[H3] Szaniszlo P. Wang N, Sinha M, Reece LM, Van Hook JW, Luxon BA, Leary JF. Getting the right cells to the array: Gene expression microarray analysis of cell mixtures and sorted cells. Cytametry A $2004 ; 59(2): 191-202$

[14] Coggin $\mathrm{JH}_{3} \sqrt{\mathrm{J}}$. The implications of embryonic gene expression in neoplasia. Crit Rev Oncol Hematoll $1986 ; 5(1): 37-55$.

[15] Kaczmarek u, Castellani P. Nicolo G. Spina B, Allemanni G, Zardi L. Distribution of oncofetal fibronectin isoforms in normal, hyperplastic and neoplastic human breast tissues. Int J Cancer $1994 ; 59$ (1) 116

[16] Brack SS. Dinkelborg LM, Neri D. Molecular targeting of angiogenesis for imaging and therapy. Eur J Nucl Med Mol Imaging 2004:31 (9):4327-41.

[17] Mulder WJ, Strijkers G.J, Griffioen AW, var Bloois L, Molema G, Storm G, Koning GA, Nicolay K. A lipasomal system for contrastuentranced magnetic resonance imaging of molecular targets. Bioconiug Chem 2004,15 (4):799-806.

[18] Fabbini M, Trachsel E, Soldani P. Bindi S, Alessi P, Bracci L. Kosmeth H, Zardi L, Neri D, Neri P. Selective occlusion of tumor blood vessels by targeted delivery of an antibody-photosensitizer conjugate. Int J Cancer 2005.

[19] Neri D, Bicknell R. Tumour vascular targeting. Nat Rev Cancer $2005 ; 5(6): 436-46$.

[20] Mor-Vaknin N, Punturieri $A_{*}$ Sitwala $K_{*}$ Markovitz OM. Vimentin is secreted by activated macrophages. Nat Cell Biol $2003.5(1): 59.63$.

[21] Molsan E, Girard D. Cell surface expression of intermediate fillament proteins vimentin and lamin $B 1$ in human neutrophil spontaneous apoplosis. J Leukoc Blol 2005.

22] Boilard E. Bourgoin SG, Bernatchez C. Surette ME. Identification of an autoantigen on the surface of apoptotic human T cells as a now protein interacting with inflammatory group IIA phospholipase A2. Blood $2003 ; 102(8): 2901-9$.

[23] Huel $D$, Bagot M, Loyaux D, Capdevielle d. Conraux L, Ferrara P. Bensussan A, Marie Cardine A. SC5 mAb Represents a Unique Tool for the Detection of Extracellular Vimentin as a Specific Marker of Sezary Cells. J Immunol 2006; 176 (1):652-9. 
[24] Tang FY. Nguyen N, Meydani M. Green tea catechins inhibit VEGF-induced anglogenesis in vitro through suppression of VE-cadherin phosphorylation and inactivation of Akt molecule: Int $J$ Ceancer $2003 ; 106(6): 8711-8$.

[25] Fassina $G$, Vene $R$, Morini M, Minghelli S, Benelil R, Noonan DM, Albini A Mechenisms of infibition of tumor angiogenesis and vascular tumor growth by epigallocatechin-3-gallate. Clin Cancer Res $2004: 10(14): 4865-73$.

[26] Ermakova $S$, Choi BY, Choi HS, Kang BS, Bode AM, Dong $Z$. The intermediate filament protein vimentin is a new target for epigallocatechin gallate. $J$ Biol Chem 2005:280 (17):16882-90.

[27] Colucci-Guyon E, Portier MM, Dunia I, Paulin D, Pournin S, Babinet C. Mice lacking vimentin develop and reproduce without an obvious phenotype. Cell 1994;79 (4),679;94.

[28] Henrion $D$, Terzi $F$, Matrougui $K$, Duriez $M$, Boulanger $C M$. Colucci-Guyon $E$, Babinet $C$, Briand $P$, Friedlander G, Poitevin P, Levy Bl. Impaired flow-induced dilation in mesenteric resistance arteries from mice lacking vimentin. J Clin Invest 1997;100 (11):2909-14.

[29] Terzi $F$, Henrion D, Colucci-Guyon $E$, Federici $P$, Babinet $C_{n}$ Levy BI, Briand $P$, Friedlander $G$. Reduction of renal mass is lethal in mice lacking vimentin: Role of endothelin-nitric oxide imbalance. J Clin Invest 1997;100 (6):1520-8.

[30] Eckes $B$, Dogic $D$, Coluccj-Guyon $E$, Wang $N$, Maniotis $A$, Ingber $D$, Merckling $A$, Langa $F$, Aumailley $M$, Delouvee $A_{0}$ Koteliansky $V$, Babinet $C$. Krieg T. Impaired mechanical stability migration and contractile capacity in vimentin-deficient fibroblasts. J Cell Scil 1998;111 (Pt 13):1897-907.

[3i1] Langa $F$, Kress $C$, Colucci-Guyon $E$, Khun $H$, Vandormael-Pournin $S$, Huerre $M$, Babinet $C$. Teratocarcinomas induced by embryonic stem (ES) cells lacking vimentin: an approach to study the role of vimentin in tumorigenesis. J Cell Sci 2000;113 Pt 19:3463-72

[32] Xu B "DeWaal RM, Mor-Vaknin N, Hibbard C, Markovitz DM, Kahn ML. The Endothelial Cell-Specific Antibody PAL-E Identifies a Secreted Form of Vimentin in the Blood Vasculature. Mol Cell Biol 2004:24 (20):9198-206.

[33] Niemela $\mathrm{H}$, Elima $\mathrm{K}$, Henttinen $T$, irjala $\mathrm{H}$, Salmi M, Jalkanen $S$. Molecular identification of PAL-E, a widely used endothelial-cell marker. Blood 2005;106 (10):3405-9.

[34] Yu SS, Li HJ, Goodwin $\mathrm{GH}_{4}$ Johns EW. Interaction of non-histone chromosomal proteins HMG1 and HMG2 with DNA. Eur J Biochem 1977;78 (2):497-502.

[35] Parkikinen J, Rauvala $\mathrm{H}$. Interactions of plasminogen and tissue plasminogen activator (t.PA) with amphoterin. Enhancement of t-PA-catalyzed plasminogen activation by amphoterin. J Biol Chem $1991 ; 266(25): 16730-5$.

[36] Merenmies J, Pihlaskari $R$, Laitinen J, Wartiovaara J, Rauvala $H_{.}$30-kDa heparim-binding protein of brain (amphoterin) involved in neurite outgrowth. Amino acid sequence and localization in the filopodia of the advancing plasma membrane. J Biol Chem 1991;266 (25):16722-9.

[37] Mullins GE, Sunden-Cullberg J, Johansson AS, Rouhiainen A. Erlandsson-Harris $H_{\text {, }}$ Yang $H_{\text {n }}$ Tracey $\mathrm{KJ}$, Rauvala $\mathrm{H}_{1}$, Palmblad J, Andersson J, Treutiger CJ. Activation of human umbilical vein endothelial cells leads to relocation and release of high-mobility group box chromosomal protein 1 . Scand $J$ Immunol 2004;60 (6):566-73.

[38] Bierhaus A. Humpert PM. Morcos $M$, Wendt $T$, Chawakis T. Arnold $B$, Stern DM, Nawroth PP. Understanding RAGE, the receptor for advanced glycation end products. J Mol Med 2005.

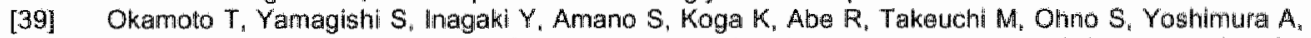
Makita $Z$. Angiogenesis induced by advanced glycation end products and itts prevention by cerivastatim. Faseb J 2002:16 (14):1928-30.

[40] Yamagishi S, Yonekura $H$, Yamamoto $Y$, Katsuno $K$, Salo F, Mita I, Ooka $H_{1}$, Satozawa N, Kawakami T. Nomura $M$, Yamamoto $H$. Advanced glycation end products-driven angiogenesis in vitro. Induction of the growth and tube formation of human microvascular endothelial cells through autocrine wascular endothelial growth factor. J Biol Chem 1997,272 (13):8723-30.

[41] Taguchi A, Blood DC, del Toro G, Canet A, Lee DC, Qu W, Tanji N, Lu Y, Lalla E. Fu C, Hofmenn MA,

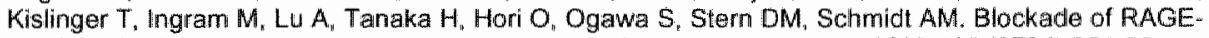
amphoterin signalling suppresses tumour growth and metastases. Nature 2000;405 (6784):354-60

[42] Van Beijnum JR, Moerkerk PT, Gerbers AJ, De Bruine AP, Arends JW, Hoogenboom HR, Hufton SE. Target validation for genomics using peptide-specific phage antibodies" a sfudly of five gene products overexpressed in colorectal cancer. Int J Cancer 2002; 101 (2):148-27.

[43] Ramaekers FC. Haag D, Kant A, Moesker O, Jap. PH, Vooijs GP. Coexpression of keratim- and vimentin-type intermediate fitaments in human metastatic carcinoma cells. Proc Natl Acad Sci U S A $1983 ; 80(9): 2618-22$

[44] Hendrix MJ, Seftor EA, Chu YW, Trevor KT, Seftor RE. Role of intermediate filtaments in migration, invasion and metastasis. Cancer Metastasis Rev 1996;15 (4);507-25.

[45] Gilles C. Pollette M, Zahm JM, Tournier JM, Volders L. Foidart JM, Birembaut P. Vimentin contributes to human mammary epithelial cell migration. J Cell Sci 1999;112 (Pt 24):4615-25.

[46] Fages $\mathrm{C}$. Nolo R, Huttunen $\mathrm{H} J$, Eskelinen $E$, Rauvala $H$. Regulation of cell migration by amphoterim. J Celli Sci 2000:113 ( Pit 4):611-20. 
[47] Huttunen HJ, Rauvala $H$. Amphoterin as an extracellular regulator of cell motitity: from discowery to disease. II Intern Med 2004;255 (3):351-66.

[48] Borsi $L$, Balza E, Bestagno M, Castellani P, Carnemolla B. Biro A, Leprini A, Sepulveda J, Burrone $O$, Meri $D_{1}$ Zardi $L$. Selective targeting of tumoral vasculature: comparison of different formats of an antibody (L+9) to the ED-B domain of fibronectin. Int J Cancer 2002;102 (1);75 85 .

[49] Ruostahti $E$, Rajotte D. An address system in the vasculature of normal tissues and tumors. Annu Rev Immunol $2000 ; 18: 81327$.

[50] Rybak JN, Ettorre A, Kaissling B, Giavazzi $R$, Neri $D$, Elia $G$. In vivo protein biotinylation for identification of organ-specific antigens accessible from the vasculature. Nat Methods 2005;2 (4):2918 .

[51] Oh P, LI Y, Yu J, Durr E, Krasinska KM, Carver LA, Testa JE, Schnitzer JE. Subtractive proteomic mapping of the endothelial surface in lung and solid tumours for tissue-specific therapy. Nature $2004: 429(6992): 629-35$

[52] Greenberg DA . Jin K. From angiogenesis to neuropathology. Nature 2005;438 (7070):954-9.

[53] Carmelliet P. Angiogenesis in life, disease and medicine. Nature 2005;438 (7070) 932-6.

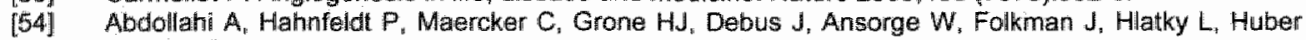
PE. Endostatin's antiangiagenic signaling network. Mol Cell 2004;13 (5):649-63.

[55] Thijssen $V L$. Brandwijk RJ, Dings RP, Griffioen AW. Angiogenesis gene expression profiling in xenograft models to study cellular interactions. Exp Cell Res 2004;299 (2):286-93. 


\section{Summary}


Angiogenesis, the formation of new blood vessels from pre-existing ones, is puvotal to a variety of physiological as well as pathological processes. Angiogenesis can be switched on in response to various stimuli, including hypoxia, metabolic stress and cellular signals. The hypothesis that tumor growth is angiogenesis-dependent was postulated over three decades ago and triggered a wide interest in inhibiting this process as a novel therapeutic strategy to treat cancer. Therapeutic inhibition of tumor angiogenesis is considered to have a number of major advantages over the current conventional therapies. Endothelial cells are easily accessible via the blood stream, are genetically stable and eradication of only a limited number of endothelial cells will result in the death of a multitude of tumor cells. Two general strategies can be employed to attack the tumor's blood supply. Either the formation of novel blood vessels can be inhibited - the narrow definition of angiogenesis unhibition - but it is also possible to destroy existing tumor vessels - frequently referred to as vascular targeting. However, depending on the mode of action of the agent, there is considerable overlap between these two applications. Nevertheless, for the design of effective angiogenesis inhibitors or vascular targeting agents for cancer treatment, thorough knowledge of endothelial celll biology is a prerequisite.

Analysis of gene expression can be used to determine molecular changes associated with particular phenotypes or diseases. The data can provide insight in the molecular mechanisms and pathways that govern disease. Importantly, differentially expressed genes may be used as targets for therapeutic intervention. The identification of putative targets for therapeutic intervention in tumor angiogenesis or for vascular targeting promises the combined specificity of targeted therapy and the efficacy of attacking the tumor vasculature.

In chapter 2 we analyzed published data of gene expression profiles of endothelial cells stimulated with growth factors in vitro, tube forming endothelial cells in vitro and isolated endothelial cells in vivo. Though different experimental setups were used, several genes were generally upregulated after growth factor stimulation in witro. Moreover, these genes were biased towards those involved in cell-cycle regulation and metabolism. This 'cell-cycle signature' can be ascribed to the transition from quiescent to activated proliferative endothelium under the influence of these growth factors. Endothelial cells differentiating into tube-like structures exhibit a gene expression profile indicative of cell-cell and cell-matrix interactions, evidenced by upregulation of adhesion molecules (e.g. ICAM1, VCAM1, NRCAM), integrims (ITGA2, ITGAV) and matrix turnover proteins (MMP1, MMP9, CTSB). Finally, genes identified by SAGE to be overexpressed in different tumor endothellal cells were evaluated. Again, genes involved in matrix remodeling and deposition are highly upregulated, such as different types of collagens and SPARC, representative of later stages of angiogenesis.

In chapter 3 we describe the analysis of gene expression in endothelial cells of malignant as well as non-malignant angiogenic tissues and compare this with glene expression in resting endothelial cells. By these means, genes that are commonly upregulated during angiogenesis are filtered out to yield only those that mark events 
associated with tumor angiogenesis. These tumor angiogenesis genes (TAGs) might be useful targets for imaging, diagnosis and therapy. When examining the functional classification of the TAGs, it emerges that there is a considerable bias towards genes associated with extracellular matrix remodeling. General angiogenesis genes (GAGs) can be divided into two groups: (i) those that are overexpressed in tumor endothelium (compared to normal endothelium) and simultaneously in placenta endothelium (compared to normal endothelium) (GAG/A), and (ii) genes that are overexpressed in tumor endothelium and simultaneously in activated HUVEC (GAG/B). The functional profile of GAG/A genes shows a bias to cell-adhesion whereas the GAG/B genes are biased towards cell and protein turnover. In conclusion, tumor endothelial cells are a heterogeneous population "containing cells in different stages of the angiogenic cascade. Furthermore, in vitro models of tumor conditioned endothelial cells are only of limited value in representing the in vivo events during tumor angiogenesis. Also, many genes are induced during both physiological angiogenesis and tumor angiogenesis. When translating putative candidate genes to a clinical setting, care must be taken not to interfere with physiological angiogenesis. Finally, we show in chapter 3 that targeting TAG-39, vimentin, with antibodies in a mouse tumor model is capable of inhibiting tumor growth and tumor vessel density.

In chapter 4 the contribution of vimentin to different aspects of the angiogenesis process is further characterized. Vimentin can be detected on non-permeabilized cells, suggesting cell-surface expression of the protein on endothelial cells. Downregulation of total vimentin by different knockdown strategies suggests that a threshold level of vimentin is necessary for survival of endothelial cells, whereas downregulation of surface-associated vimentin results in impaired migration and tube formation. This surface-associated pool of vimentin is increased in exponentially growing cells and might be regulated by phosphorylation as treatment with the phosphatase inhibitor okadaic acid results in increased vimentin immunoreactivity of non-permeabilized cells, but not of permeabilized cells. Our data suggest that surface-exposed vimentin contributes positively to cell migration and tube formation, and that interference with the expression or the function of this pool negatively impacts the angiogenic potential of endothelial cells.

In chapter 5 the contribution of TAG-21 (HMGB1) to angiogenesis is addressed. Inhibition of HMGB1 protein expression inhibited cell migration and MMP9 expression, suggesting an active involvement of HMGB1 in this process. Targeting HMGB1 in vitro with antibodies inhibited migration and tube formation of endothelial cells, supporting these results. In vivo, targeting HMGB1 with antibodies inhibited vessel formation on the CAM grafted with tumor cells. Taken together, HMGB1 positively contributes to angiogenesis, and targeting the protein has an anti-angiogenic effect. However, its role in inflammatory processes requires caution when translating this to a therapeutic anticancer setting.

Chapter 6 provides an outlook to the implementation of high-throughput target validation technologies and functional identification of therapeutically targetable 
molecules in angiogenesis. Major drawback of gene expression profiling techniques is that they generate vast lists of potential disease target genes, but these do not reveal functional information or direct (causative) relevance to the disease. Hence, validation of these putative targets is a time-consuming and labor-intensive process. Recent technical advances in high-throughput analysis of gene function in vitro, including library generation, transfection methods, miniaturization of assays and screening techniques have brought about the opportunity for target validation to keep up with the pace of target identification at a genomics scale. Furthermore; novel methods have been developed to identify candidate target genes based on the phenotype they induce in an unbiased screening approach. Examples of these techniques are transfected cell arrays and expression library screening in vitro that allow functional annotation of genes in a high-throughput setting. Genetic screens, either gain-of-function or loss-of function, can be applied to directly identify candidate genes that confer a selectable phenotype to the cells.

In conclusion, we have shown that tumor endothelial cells exhibit a gene expression profile that distinguishes them from cultured endothelial cells as well as from endothelial cells in non-tumor angiogenic tissue. Functional analysis indicated these genes are heavily biased towards extracellular matrix remodeling. We identified both genes previously acknowledged for a role in angiogenesis and genes not previously associated with angiogenesis. In vitro angiogenesis assays demonstrate the essential contribution of HMGB1 and vimentin to endothelial cell migration and tube formation. In vivo, therapeutic targeting of tumor vascular vimentin reduced tumor growth and vessel density, demonstrating the efficacy of our approach. Hence, the tumor angiogenesis genes (TAGs) we identified are promising candidate targets for therapeutic anticancer treatment. 


\section{Samenvatting}


Angiogenese, de vorming van nieuwe bloedvaten uit bestaande vaten, is vereist voor een aantal fysiologische alsook pathologische processen. Het angiogeneseproces kan worden geïnitieerd in reactie op verschillende stimuli, waaronder hypoxie, metabole stress en cellulaire signalen. De hypothese dat tumorgroei angiogeneseafhankelijk is, werd meer dan dertig jaar geleden voor het eerst geuit en heeft bij velen interesse gewekt in het concept dat angiogenese-inhibitie een nieuwe manier is om kanker te behandelen.

Angiogenese-inhibitie als antikanker therapie heeft een aantal voordelen: de endotheelcellen die de binnenkant van een bloedvat bekleden, zijn gemakkelijk bereikbaar via het bloed, zijn genetisch stabiel, en het doden van een beperkt aantal endotheelcellen heeft de dood van een meervoud aan tumorcellen tot gevolg. Twee algemene strategieën kunnen worden gebruikt om de bloedvatvoorziening van een tumor aan te vallen. De vorming van nieuwe bloedvaten kan worden geremd angiogenese-inhibitie - maar het is ook mogelijk om bestaande vaten te vernietigen meestal vasculaire targeting genoemd. Afhankelijk van de werking van een stof kan deze zorgen voor zowel angiogenese-inhibitie als vasculaire targeting, waardoor er redelijk veel overlap is tussen deze termen. Hoe dan ook, voor het ontwerpen van therapeutica met deze eigenschappen is een specifieke kennis van de endotheelcelbiologie vereist.

Genexpressie-analyses kunnen worden gebruikt om de moleculaire veranderingen te bepalen die gepaard gaan met een ziekte of een ander proces. Hiermee worden de moleculaire mechanismen waarvan de ziekte afhankelijk is duidelijk. De identificatie van targetmoleculen die geschikt zijn voor therapeutische interferentie belooft een mogelijke therapie die zowel zeer specifiek werkt, alsook zeer effectief is.

In hoofdstuk 2 hebben we gepubliceerde genexpressiedata geanalyseerd van groeifactor-gestimuleerde endotheelcellen, van buisvormende endotheelcellen, en van uit weefsels geïsoleerde endotheelcellen. Hoewel in deze studies verschillende experimentele methoden werden gebruikt, is er een aantal genen aan te wijzen die onder invloed van angiogene groeifactoren verhoogd tot expressie komen. Veel van de groeifactor-gereguleerde genen zijn betrokken bij regulatie van de celcyclus en bij metabole processen, wat waarschijnlijk te maken heeft met de overgang van rustend endotheel naar geactiveerd endotheel onder invloed van angiogene factoren. Het genexpressieprofiel van buisvormende endotheelcellen wijst op cel-cel en cel-matrix interacties, aangezien vele adhesiemoleculen (bv. ICAM1, VCAM1 en NRCAM), integrines (ITGA2, ITGAV) en matrix-afbrekende eiwitten (bv. MMP1, MMP9, CTSB) verhoogd tot expressie komen. In endotheelcellen die waren geïsoleerd uit tumoren kwamen ook met name die genen die betrokken zijn bij de afzetting van matrixmoleculen en de herstructurering van matrix, zoals SPARC en verschillende collagenen, verhoogd tot expressie.

In hoofdstuk 3 beschrijven we het genexpressieprofiel van endotheeicellen geïsoleerd uit zowel maligne als niet-maligne angiogene weefsels en vergelijken dit met het genexpressieprofiel van normale, rustende endotheelcellen. Op deze manier 
kunnen de genen die betrokken zi.jn bij fysiologische angiogenese worden uitgefilterd en blijven juist de genen die betrokken zijn bij tumorangiogenese over. Deze tumorangiogenese genen (TAGs) zouden bruikbare targets kunnen zijn voor beeldvormende technieken om angiogenese zichtbaar te maken, alsook voor diagnostische doeleinden en voor therapeutische doeleinden. Wanneer we kijken naar de functionele classificatie van deze TAGs, valt op dat vele betrokken zijn bij de herstructurering van de extracellulaire matrix. Genen die ook betrokken zijn bij fysiologische angiogenese (GAGs) kunnen in twee groepen worden onderverdeeld: (i) genen die verhoogd tot expressie komen in tumorendotheel (vergeleken met normaal endotheel) en tegelijkertijd in placenta-endotheel (vergeleken met normaal endotheel) (GAG/A), en (ii) genen die verhoogd tot expressie komen in tumorendotheel (vergeleken met normaal endotheel) en tegelijkertijd ook in geactiveerde HUVEC (GAG/B). Een groot deel van de GAG/A genen is betrokken bij celadhesie, terwijl GAG/B genen voornamelijk betrokken zijn bij celdeling en eiwitproductie. Tumorendotheelcellen vormen dus een heterogene populatie, bestaande uit cellen die zich in verschillende fasen van het angiogenese proces bevinden. Verder is gebleken dat endotheelcellen gekweekt in aanwezigheid van geconditioneerd medium van tumorcellen weinig overlap in genexpressieprofiel vertonen met endotheelceillen geilsoleerd uit tumoren. Dus, in vitro modellen zijn maar in een beperkte mate representatief voor de in vivo situatie. Ook zijn veel genen bij zowel fysiologische angiogenese als tumorangiogenese betrokken. Bij de implementatie van mogelijke kandidaatgenen in een klinische toepassing voor de behandeling van kanker, moet worden voorkomen dat fysiologische angiogenese wordt geremd. Ten slotte tonen we in hoofdstuk 3 aan dat antilichamen gericht tegen TAG-39, vimentine, tumorangiogenese en tumorgroei in een muismodel remmen.

In hoofdstuk 4 hebben we de bijdrage van vimentine in verschillende aspecten van angiogenese bekeken. Het feit dat we vimentine kunnen detecteren op nietgepermeabiliseerde cellen duidt erop dat vimentine ook op het oppervlak van endotheelcellen tot expressie komt. Remming van vimentine-expressie laat zien dat endotheelcellen een minimale hoeveelheid vimentine nodig hebben om te overleven en dat remming van celoppervlak gerelateerde vimentine-expressie de migratie en buisvormende capaciteit van endotheelcellen remt. Vimentine-expressie gerelateerd aan de oppervlakte van de cel is verhoogd in exponentieel groeiende cellen en wordt mogelijk gereguleerd door fosforylering, aangezien de fosfataseremmer okadaic acid zorgt voor een verminderde immuunreactiviteit van niet-gepermeabiliseerde cellen, maar niet van gepermeabiliseerde cellen. Dit alles duidt erop dat celoppervlakgerelateerd vimentine een bijdrage levert aan endotheelcel migratie en buisvorming, en dat het remmen van de functie of de expressie van deze vimentinefractie een negatieve invloed heeft op angiogene processen.

In hoofdstuk 5 beschrijven we de bijdrage van TAG-21, HMGB1, aan het angiogeneseproces. Remming van HMGB1 expressie remt endotheelcelmigratie en MMP9 expressie, wat duidt op een actieve rol van HMGB1 in angiogenese. 
Antilichamen gericht tegen HMGB1 remmen migratie en buisvorming van endotheelcellen in vitro, en de bloedvatvorming onder invloed van tumorcellen op het chorionmembraan van het kippenei in vivo. Samengevat levert HMGB1 een positieve bijdrage aan angiogenese, en heeft remming van het eiwit een anti-angiogeen effect. Aangezien het eiwit ook een rol speelt in ontstekingsreacties, dient eventuele implementatie in een klinische setting met grote voorzichtigheid te gebeuren.

Hoofdstuk 6 beschouwt de implementatie van geavanceerde targetvalidatietechnologieën en de functionele identificatie van therapeutische targets voor toepassing in angiogenese onderzoek. Genexpressiestudies resulteren in lange lijsten met genen die veranderd tot expressie komen tijdens ziekte, maar geven geen directe functionele informatie over het gen of informatie over een causale bijdrage aan het ziektebeeld. Validatie van deze genen voor hun mogelike bruikbaarheid voor therapeutische doeleinden is zeer tijdrovend en arbeidsintensief. Nieuwe, geavanceerde technologieën om de functie van genen te bestuderen, zoals het produceren van genenbanken, transfectiemethoden, miniaturisatie van experimenten en screeningsmethoden, stellen ons nu in staat het target-validatieproces in de pas te laten lopen met het target-identificatieproces. Nieuwe methoden zijn ontwikkeld om kandidaatgenen te identificeren, gebaseerd op het fenotype dat ze induceren. Voorbeelden van deze technieken zijn arrays van getransfecteerde cellen en het screenen van expressie-genenbanken om de functie van genen te analyseren. Genetische screens, zowel voor toename als voor verlies van functie, kunnen worden gebruikt om kandidaatgenen te identificeren die een selecteerbaar fenotype induceren.

In dit proefschrift tonen we aan dat tumorendatheelcellen een genexpressieprofiel hebben dat ze onderscheidt van gekweekte endotheelcellen alsook van endotheelcellen in niet-maligne angiogene weefsels. Veel van deze genen zijn betrokken bij de herstructurering van de extracellulaire matrix. Van een aantal van deze genen was hun betrokkenheid bij anglogenese al vastgesteld, maar van een aantal nog niet. Onze experimenten tonen aan dat vimentine en HMGB1 een rol spelen in de migratie en buisvorming van endotheelcellen. Het remmen van vasculair vimentine remt tumorgroei en angiogenese in een muismodel en demonstreert de toepasbaarheid van onze studie. De tumorangiogenese genen (TAGs) die wij hebben geïdentificeerd zijn veelbelovende kandidaat genen voor de ontwikkeling van nieuwe therapieèn voor de behandeling van kanker. 


\section{Dankwoord}


ZOEF... he wat was die windwaag? Oh, een Judy..

Waarschijnlijk een bekend fenomeen voor eenieder die mij wel eens op het lab is tegengekomen, nou ja, die ik ooit ben voorbijgevlogen. Ik zal dus maar beginnen met ledereen te bedanken die op tijd is opzij gesprongen, al dan niet gewaarschuwd door het geluid van mijn schoenen en/of een plotselinge verandering in luchtdruk.

$\mathrm{Nu}$ is het echter even tijd om stil te staan bij iedereen die ik te vaak en te snel voorbij ben gerend. Ik neem jullie een aantal jaren mee terug in de tijd. Mijn moeder voorzag dat ik professor in de weet-niet-kunde zou worden. Nou, doctor ben ik nu, en misschien word ik nog ooit professor in de weet-iets-kunde. Mijn vader legde mij aan de hand van de wetten van Mendel uit waarom rode koeien zwarte kalfjes konden krijgen, en daarmee is mijn interesse in genetica en later genexpressie gewekt. Ben ik nu van de melkboer of een hooimeid, of allebei?

Mijn eerste stapjes zette ik tientallen jaren geleden welliswaar bij mijn ouders thuis in de kamer, maar mijn eerste stapjes in het onderzoek bij Pathologie. Hard werken ging hier gepaard met de nodige (on)gein, niet in het minst door de aanwezigheid van mijn toenmalige labgenoten (ja helaas, de verleden tijd van labgenieten), waaronder Marco, Guido, Helen, Natasja en Ricardo. Na deze 'fage' periode brak een nieuw tijdperk aan met angiogenese als sleutelwoord, gekenmerkt door zowel oude als nieuwe gezichten. Arjan gaf me de gelegenheid bestaande en nieuwe ideeèn met elkaar te verenigen. Hoewell ik al heel wat kneepjes van Ricardo en Peter had geleerd, was cellen kweken toch wel even wat nieuws. Nestor Daisy (is hier een vrouwelijk woord voor?) lliet zien hoe je uit een bloederige navelstreng een florerende endotheelcelpopulatie haalt. Susan nam het vervolgens op zich om deze cellen uit al even bloederige placenta's, tumoren en darmen te halen, een kunstvorm die later door Edith met verve is uitgebouwd. Ook wist Edith altijd 'fac(t)s' van fictie te scheiden op de flowcytometer. Voor DNA drama's en de juiste vector was Victor de aangewezen persoon. Carolien heeft tijdens haar korte stageperiode de ski's en sno's uitgezocht, maar helaas liggen deze data nog ondergesneeuwd. Bernadette en Wouter wisten naast waardevolle data ook heerlijke appeltaarten te produceren.

Natuurlijk heb ik niet alles alleen te danken aan mijn collega"s. Een goede buur is je beste vriend. Met Thijs, Femke en Mokkie vaak genoten van alle gezellige barbeknoeis, vino's, appeltaarten, tapas, nog meer vino's, witte haren en nagels in mijn schouders; zeer geschikt om na een dagje rondvliegen op het lab de zinnen te verzetten. Laten we er nog veel van genieten! Bram en Koannie, van huisgenoten tot vrienden tot buren; Sietske en Ivo, van collega's tot vrienden tot burer; en tot paranimfen. De beste buren kun je ook kiezen! De Roserije is er niet op achteruitgegaan de afgelopen jaren, het bierpeil in onze koelkast daarentegen des te meer. Gelukkig weet Peet dat altijd in goede banen te leilden en wordt de koekast gevuld. Truus gevoerd en veel gesmuld. Liefde gaat toch ook wel een beetje door de maag. Huisje, boompje, Hummertje; we hebben het bijna voor elkaar.

Een goede collega is ook je beste vriend. Vele heerlijke, en af en toe ook minder heerlijke recepten zijn de afgelopen jaren de revue gepasseerd. Wanneer koken nog 
eens onderdeel wordt van een sollicitatie zitten Chiel, Nicole, Rob, Ricardo, Caroline en Louise in ieder geval gebakken. Afgewisseld met lab-praat over sequencen, weekendjes met twister en liplezen, de nodige biertjes en de nieuwste wasmiddelentips (hoezo we worden oud ?!), komen we toch maar de woensdagavonden door. De pannekoeken (pannenkoeken?) van Barry zullen ons trouwens ook nog lang heugen, evenals de breezer-salade, het breezer-ontbijt, de breezer-lunch en breezer-apresswim.

Terug naar het heden... Voor jullie ligt een boekje dat ondanks mijn haat-liefde verhouding met Microsoft toch tot strand is gekomen. Meermalen kwam het stoom uit mijn oren, doch niet uit mijn computer. Misschien heeft dit te maken met de paradox dat multi-tasken een vrouweneigenschap is en Bill Gates een man is? Gelukkig is het koffieapparaat geduldig en geeft MSN voldoende slachtoffers om virtueel op af te reageren <<buzzz>>. Ik ga er vanuit dat mijn kamergenoten wel weten dat alle scheldkanonnades nooit bedoeld zijn geweest om hen onder vuur te nemen. Tja, soms is mijn stressbestendigheid nu eenmaal rechtevenredig met de crashbestendigheid van mijn computer.

Zonder Els ook was de Nederlandse samenvatting verdwaald geraakt in de jungle van uitgaven van het groene boekje en veranderende spellingsregels. En ondanks of misschien wel dankzij zijn zeebenen was Jan altijd een rots in de branding. Wanneer optimisme en vertrouwen nog eens in pilvorm verkrijgbaar worden kunnen we hier op de afdeling wel inpakken.

Op naar de toekomst... een paar opmerkingen. Allereerst wil ik mijn mede-AlOs, Veerle, Debby, Ricardo, Karolien en Femke heel veel succes wensen met het schrijven van hun dankwoord. Tenslotte, eenieder die aan dit onderzoek, of op een andere manier aan de totstandkoming van dit proefschrift hebben bijgedragen: gracias,

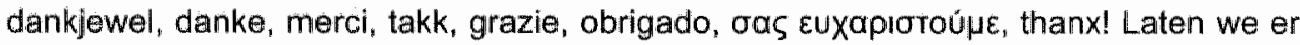
een leuk feest van maken! 


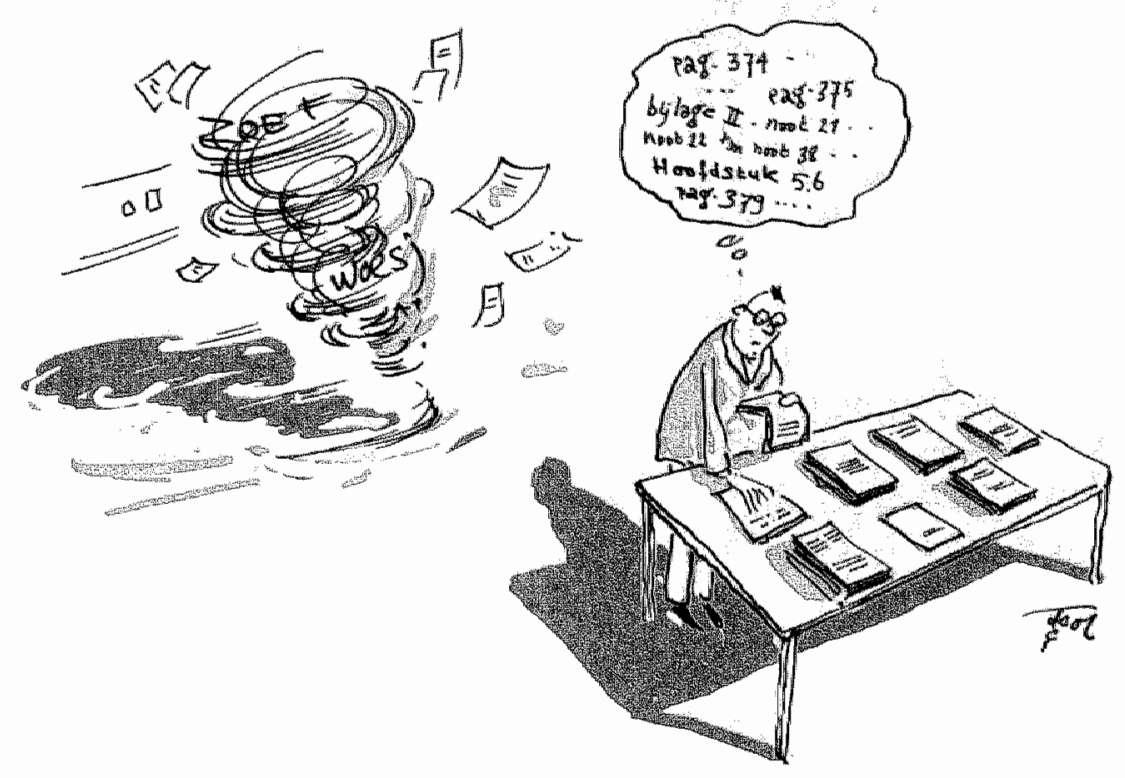

Tat op dat moment had orkazh Judy nog miet veet schadc aamgericht. 


\section{Curriculum Vitae}




\section{Judy van Beijnum}

Judith Rosina van Beijnum was born on December $11^{\text {th }} 1977$ in Nijmegen, The Netherlands. Following primary school in Horssen, she completed her secondary education at the Pax Christi College in Druten in 1995. In August 1995 she started at Maastricht University with studies in Health Sciences. Between 1995 and 1999, she was also actively involved in diverse committees of student association S.V. KoKo, which aimed to introduce first-year students to the city of Maastricht and its social life.

She decided to specialize in Biological Health Sciences and in 1999, she was introduced into the world of research. Her first internship was under supervision of $d r$. Simon Hufton and dr. Hennie Hoogenboom, during which she validated potential colorectall cancer antigens. This internship was extended with a project in which she isolated and characterized anti-peptide phage displayed antibodies that target colorectal cancer antigens. In May 2000 she obtained her MSc degree and started as PhD student at the department of Pathology, in the group CESAME, continuing the work initiated during her internship.

After the collapse of CESAME in May 2001, she initiated a new PhD project at the Angiogenesis Laboratory under supervision of Prof. dr. Arjan Griffioen. Since then, she has studied gene expression in endothelial cells under different angiogenic and nonangiogenic conditions to identify novel targets for the treatment and imaging of human tumors. As of April 2006, she will continue these studies as a post-doc in the Angiogenesis Laboratory. 


\section{$>$ Publications}

Van Beiinum JR, Dings RPM, Van der Linden E, Zwaans BMM, Ramaekers FCS, Mayo KH, Griffioen AW. Gene expression of tumor angiogenesis dissected; specific targeting of fumor endothelium. Submitted

Mulder WJ, Castermans, KC, Van Beijnum JR, Oude Egbrink MGA, Chin PTK, Storm G, Strijkers GJ, Griffioen AW, Nicolay K. Multimodality molecular imaging of tumor angiogenesis using quantum dots. Submitted

Derksen PWB, Liu X, Saradin F, Evers B, Van Beijnum JR, Griffioen AW, Van der Gulden $H$, Zevenhoven J, Peterse $H$, Cardiff R, Vink J, Krimpenfort P, Berns A, Jonkers J. Somatic inactivation of E-cadherin and p53 leads to metastatic lobular breast cancer. Submitted

Hillen F, Melotte V, Van Beijum JR, Griffioen AW. Endothelial cell biology. In: Staton $C$, Lewis $C$, Bicknell R, editors. Angiogenesis assays: a critical appraisal of current techniques, London: John Wiley and Sons, In press.

Van Beiinum JR, Eijgelaar WJ, Griffioen AW. Towards high-throughput functional target discovery in angiogenesis research. Trends Mol Med. 2006 Jan; 12(1):44-52

Van Beijnum JR, Griffioen AW. In silico analysis of angiogenesis associated gene expression identifies angiogenic stage related profiles. Biochim Biophys Acta. 2005 Jul $25 ; 1755(2): 121-34$.

Van Beilnum JR, Fan TP. Griffioen AW. Euroconference Angingenesis 4. Angiogenesis. 2003;6(3):159-64.

Van Beilinum JR. Griffioen AW. Transcriptional profiling of angiogenically activated endothelial cells: gene expression reflects the angiogenic stage. Applied Genomics and Proteomics 2003:2(4):207-223.

Van Beijnum JR, Moerkerk PT, Gerbers AJ, De Bruine AP, Arends JW, Hoogenboom HR, Hufton SE. Target validation for genomics using peptide-specific phage antibodies: a study of five gene products overexpressed in colorectal cancer. Int $J$ Cancer. 2002 Sep 10;101(2):118-27. 


\section{> Posters and abstracts}

$15^{\text {th }}$ Endothelial cell research symposium, Maastricht, 2004

Van Beijnum JR, Van der Linden E, Griffioen AW. The transcriptional profile of tumor endothelial cells indicates distinct stages of angiogenesis, implications for anticancer therapy

Published in:

Abstracts of the 15th Endothelial Cell Research Symposium Maastricht, The Netherlands. Angiogenesis. 2004;7(2):165-187.

AACR Annual Meeting, Orlando FL, 2004

Van Beiinum JR, Van der Linden E, Griffioen AW. The transcriptional profile of tumor endothelial cells indicates distinct stages of angiogenesis; implications for anticancer therapy

EurRconference Angiogenesis II, Paris, 2003

Van Beiinum JR, Van der Linden E, Joosten S, Wagstaff J, Griffioen AW. Angiomic profiling of tumor endothelium

$2^{\text {nd }}$ International symposium on genetic anticancer agents, Valencia, 2001

Van Beiinum JR, Moerkerk PT, Gerbers AJ, De Bruine AP, Arends JW, Hoogenboom HR, Hufton SE. Gene expression profiling of colcorectal cancer and the use of antibody phage display to isolate specific targeting molecules 
Financial support for the publication of this thesis is gratefully acknowledged:

Bio-Rad

Greiner Bio-One

BD Biosciences 